Fabio Sarubbi Raposo do Amaral

Estudos moleculares em acipitrídeos (Aves, Accipitridae): uma perspectiva evolutiva

São Paulo

2008 
Fabio Sarubbi Raposo do Amaral

\title{
Estudos moleculares em acipitrídeos (Aves, Accipitridae): uma perspectiva evolutiva
}

\author{
Tese apresentada ao Instituto \\ de Biociências da \\ Universidade de São Paulo, \\ para a obtenção de Título de \\ Doutor em Ciências, na Área \\ de Genética e Biologia \\ Evolutiva. \\ Orientadora: \\ Profa. Dra. Anita Wajntal
}

São Paulo

2008 
Amaral , Fabio Sarubbi Raposo do

Estudos moleculares em acipitrídeos (Aves, Accipitridae): uma perspectiva evolutiva $\mathrm{i}+162$

Tese (Doutorado) - Instituto de Biociências da Universidade de São Paulo. Departamento de Genética e Biologia Evolutiva.

1. sistemática molecular 2. biogeografia histórica 3. comportamento migratório 4. estrutura secundária Universidade de São Paulo. Instituto de Biociências. Departamento de Genética e Biologia Evolutiva.

Comissão Julgadora:

$\operatorname{Prof}(a) . \operatorname{Dr}(a)$.

$\operatorname{Prof}(a) . \operatorname{Dr}(a)$.
$\operatorname{Prof}(a) . \operatorname{Dr}(a)$.

Prof(a). Dr(a). 
Aos pais e a companheira mais amorosos e dedicados que alguém sonharia ter. 
"It is interesting to contemplate an entangled bank, clothed with many plants of many kinds, with birds singing on the bushes, with various insects flitting about, and with worms crawling through the damp earth, and to reflect that these elaborately constructed forms, so different from each other, and dependent on each other in so complex a manner, have all been produced by laws acting around us." 
À Profa. Dra. Anita Wajntal, pela orientação, amizade, entusiasmo, paciência e incentivo a todas as idéias (algumas bem malucas) surgidas nos últimos cinco anos. Seu apoio incondicional, tanto nos momentos bons como nos difíceis, tornaram a elaboração e o desenvolvimento desta tese uma tarefa muito prazerosa.

À Profa. Dra. Cristina Miyaki, pelo apoio, ensinamentos valiosos sobre biologia molecular, e pela competência em tornar nosso laboratório um lugar muito eficiente para se trabalhar.

Ao Prof. Dr. Luís Fábio Silveira, pela contribuição na minha formação desde a época da iniciação no MZUSP, amizade, e por me convencer que sistemática e taxonomia eram muito mais interessantes do que o Pecten Oculi. Seus questionamentos, sugestões, amostras de tecido dos cantos mais escondidos do Brasil, e conhecimento profundo de aves neotropicais foram indispensáveis para o desenvolvimento desta tese.

Ao Prof. Dr. Frederick H. Sheldon, pela generosidade, confiança, apoio intelectual e financeiro, e pronto aceite para um estágio na Lovisiana State University, que me permitiu não somente a obtenção de dados indispensáveis para as análises filogenéticas, como também passar por experiências profissionais e pessoais ímpares.

Ao Prof. Dr. James Van Remsen pelas inúmeras contribuições em bem humoradas conversas, questionamentos pertinentes, saídas de campo nos EUA e, principalmente, por me proporcionar um exemplo de amor e dedicação à ornitologia.

Ao Prof. Dr. Robb T. Brumfield, pela acolhida no laboratório, pelo exemplo de competência, e inúmeras discussões nas quais aprendi muito - sem esquecer, é claro, de celebrações regadas a caipirinhas de Pitú e comida local.

Aos pesquisadores austríacos Dra. Anita Gamauf, Dr. Martin Riesing, e Dra. Elisabeth Haring, pelos ensinamentos, entusiasmo, paciência, e por terem aceitado colaborar no desenvolvimento deste trabalho com dados de espécies do Velho Mundo.

Aos colegas de laboratório do LGEMA Adri, Flá, Ci, Tânia, Camila, Fernando D'Horta, Zé, Rodrigão, Renatão, Fefê, Erwin, Poly, Jana, Pri, Renatinho, Gustavo, Melina, Érika, Celina, Patrícia, além de outros pós-graduandos do instituto, pela convivência agradável, discussões enriquecedoras e auxílios diversos durante meu doutorado. Agradecimentos especiais ao Erwin pela paciência em me introduzir na biologia molecular, e ao Fernando d'Horta pelas inúmeras caronas, nas quais aprendi muito sobre biogeografia neotropical.

A todos os estudantes de pós-graduação, pós-docs, research associates e profissionais da LSU, entre eles Andrés Cuervo, Gustavo Bravo, Zac Cheviron, Matt Carling, James Maley, Katie Faust, Haw Chuan Lin, Dan Lane, Richard Gibbon, Curt Burney, Santiago Claramunt, Cheryl Haynes, Ali Jenning, Ben Marks, "CJ" Hayden, Nathan Jackson, Jamie Oaks, Susan Murray, Peggy Sims, Tammie Jackson, Donna Dittman e Steve Cardiff, pelo apoio das formas mais diversas, e por permitir que os seis meses fora do País deixassem saudades não de colegas, mas de grandes amigos. Agradecimentos especiais ao Dan por me acolher (com bastante paciência) por este período em sua casa, e dividir não somente as contas, mas também seu talento com aves neotropicais; a Richard e Curt (e suas companheiras) por topar incursões (bem) freqüentes ao Chelsea's para longas horas de pebolim, além de ensinamentos dos aspectos mais obscuros da língua inglesa; à Melanie por ter sido uma irmã mais velha postiça muito competente; e à Susan pelo seu bom humor, apoio e ajuda nos momentos em que estive mais sobrecarregado.

Ao Dr. Sérgio Pereira, pelo apoio em todos os momentos, e pronto suporte às perguntas mais complicadas sobre métodos de análise. 
Aos professores da USP Dra. Mariana C. de Oliveira, Dr. Fernando Marques, Dra. Lurdes Foresti, e na LSU, o Dr. Michael Hellberg e o doutorando Ron Eytan, por permitir o uso de seus laboratórios no processamento de amostras de museu.

Aos professores Dr. Fernando Marques e Dr. Antonio Marques, pelo ajuda na análise de dados no cluster da Zoologia, e principalmente, pelos ensinamentos sobre sistemática e confrontos de idéias sobre critérios de otimização, fora e dentro da disciplina ministrada por eles. Dois grandes mestres da sistemática, aos quais devo muito do que aprendi.

Aos outros diversos professores com os quais estudei disciplinas que me auxiliaram muito no desenvolvimento da tese, como Dra. Elisabeth Höfling, Dr. Gabriel Marroig e Dr. Sérgio Matioli.

À Silvia Geurgas pela valiosa ajuda com o seqüenciamento, além do apoio e divertidíssimas conversas.

A todos os funcionários do Instituto de Biociências, em especial Luceleni e Maria, por ajudarem direta ou indiretamente de infinitas maneiras.

Ao doutorando do STRI Matthew Miller e seu co-orientador Prof. Dr. Eldrege Bermingham, pelo auxílio na obtenção de dados de algumas amostras da LSU, em uma época que estas estavam fora de meu alcance, e contribuições geniais ao primeiro manuscrito oriundo deste trabalho. À Érika Tavares pela ajuda com análises e obtenção de seqüências de parte das amostras da ANSP também durante esta mesma época, e ao Prof. Dr. Allan Baker por permitir a obtenção destes dados por ela em seu laboratório no ROM (Canadá).

A todas as pessoas e instituições envolvidas na dura tarefa de amostrar um grupo pouco coletado como os acipitrídeos, entre elas Donna Dittman, Robb Brumfield e Fred Sheldon (LSUMZ); John Bates e David Willard (FMNH); Leo Joseph e Nate Rice (ANSP); Alexandre Aleixo e Marcos Pérsio D. Santos (MPEG); Anita Gamauf e Lisi Haring (NHMW); Marcelo Soares (UFPA); Carlos E. A. Carvalho, Eduardo P. M. de Carvalho Filho, Giancarlo Zorzin, Gustavo D. M. de Carvalho e Marcus Canuto (SOS Falconiformes); Pedro Scherer Neto (Museu de História Natural Capão do Imbuía); Zoológico de Paulínia; Ricardo Pereira (Zoológico de São Paulo); Leo Fukui e Jorge Lisboa (ABPFAR); David Whitacre, Rick Watson e Martin Gilbert (Peregrine Fund); Tammo Hoeksema (ZOOMAT); Sérgio Aguilar (Veracruz Pronatura); Alexandre Miranda, José H. Fontenele, Greicelene R. Pedro (Orquidário de Santos); Renato Gaban Lima e Guilherme Renzo (USP); Adriana Joppert (DEPAVE/SP); Robson Silva e Silva e Fábio Olmos. Agradecimentos especiais a John Bates e David Willard pelas diversas amostras e (muitos) espécimes emprestados durante meu estágio.

Aos nossos competidores estrangeiros, por oferecerem um desafio adicional, me forçando a publicar, aprender a espremer melhor os dados, e me estimulando a trabalhar cada vez mais.

Aos meus pais, Luiz e Cristina, meus irmãos, Alexandre e Luciana, e minha cunhada Isa, pelo amor, compreensão e apoio, e por representar uma família fantástica. Muito obrigado por entender minha ausência, ansiedade e confinamento nos últimos cinco anos, sem vocês nada disso existiria.

À Cibele, em um primeiro momento colega de bancada, e de quase quatro anos para cá minha companheira. Obrigado pelo amor, lealdade, apoio e dedicação incondicionais, e pela capacidade de me fazer achar que os problemas que encontrei pela frente não eram tão grandes assim. Agradeço também à minha nova família (Vanilda, Álfio, Fabrício, Flávia) pelo apoio.

Aos meus tios e primos, em especial tio Goffredo, tia Maria Eugênia e Olívia, pelo apoio incondicional desde os tempos de faculdade.

A todos aqueles que não foram incluídos nesta seção, mas que contribuíram no desenvolvimento deste trabalho.

Por fim, mas não menos importante, agradeço o apoio recebido de agências de fomento na forma de bolsa de doutorado (FAPESP), bolsa sanduíche (CAPES) e diversos tipos de auxílio ao laboratório (FAPESP, CAPES, CNPq), sem os quais seria impossível o desenvolvimento desta tese. 


\section{Índice}

Resumo 1

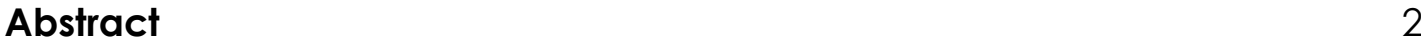

Capítulo 1. Introdução geral 3

Capítulo 2. Inferência filogenética e biogeografia histórica dos gaviões buteoninos (Aves, Accipitridae): padrões e processos de diversificação em um grupo ecologicamente diverso e amplamente distribuído

Capítulo 3. Um modelo de estrutura secundária do rRNA 165 de Aves baseado em análise comparativa 88

Capítulo 4. Conclusões 109

Anexos 


\section{Resumo}

A família Accipitridae representa uma das maiores radiações de aves atuais, ocupando habitats diversos em grande parte do planeta. Entre as divisões propostas para a família no passado, o grupo dos gaviões buteoninos figura entre um dos poucos que se aproximam em composição a uma linhagem monofilética, de acordo com análises filogenéticas recentes. Além de ocorrer tanto no Novo Mundo como no Velho Mundo, a maior parte das espécies de gaviões buteoninos está concentrada na América do Sul e na América Central, o que os torna um modelo atrativo para a análise de padrões e processos de diversificação em escalas continental e local. Outro aspecto interessante do grupo é o grande número de espécies migratórias, padrão ainda pouco explorado sob uma perspectiva filogenética.

Os principais objetivos deste trabalho foram inferir as relações filogenéticas entre as espécies de gaviões buteoninos, analisar a evolução do comportamento migratório no grupo, e inferir padrões e processos de diversificação, com ênfase na região Neotropical. Foram utilizados mais de 7.000 pares de base de DNA mitocondrial e nuclear de 51 espécies de gaviões buteoninos, compreendendo o maior estudo filogenético do grupo até o momento. Do total de seqüências utilizadas, cerca de um terço foi representado por seqüências de DNA do 12S, tRNAVal e 16S, que contém uma proporção de sítios de evolução dependente resultante da existência de uma estrutura secundária. Como forma de avaliar o impacto destes sítios nas estimativas, foram também realizadas análises alternativas que incorporaram informação de estrutura secundária. Devido à indisponibilidade de um modelo de estrutura secundária de 165 para aves, este foi aqui elaborado com base em uma análise comparativa de representantes de todas as ordens de aves atuais.

Os resultados sugerem que os gêneros Buteo, Leucopternis e Buteogallus como atualmente reconhecidos não são monofiléticos, o que ressalta a falta de concordância entre a classificação atual e a histórica evolutiva do grupo. Cinco linhagens principais foram encontradas, sendo a base da árvore composta por espécies predominantemente neotropicais, e a porção mais derivada principalmente por espécies neárticas e do Velho Mundo. Este resultado, associado às estimativas de tempo de divergência, sugere um longo período de diversificação na região Neotropical (com início entre o Oligoceno Superior ou o Mioceno, e se estendendo até o Pleistoceno), com colonização e diversificação recentes na região Neártica e no Velho Mundo (com início no Mioceno Superior ou no Plioceno, se estendendo até o Pleistoceno). O comportamento migratório evolviu diversas vezes, e pode ter contribuído para a diversificação de algumas espécies, ao possibilitar a colonização de habitats antes não ocupados e promover especiação em ilhas.

Na região Neotropical, disjunções de espécies de florestas de terras baixas que ocupam áreas a leste e oeste dos Andes ocorreram quatro vezes, possivelmente em dois eventos vicariantes. As disjunções mais antigas podem ter sido causadas pelo soerguimento da cordilheira, enquanto não foi possível definir claramente os processos envolvidos nas especiações mais recentes. Foram encontradas duas linhagens distribuídas em habitats alagados e ripários. Os resultados sugerem não somente um longo processo de diversificação, de forma independente das espécies de florestas não alagadas, mas também conexões históricas entre florestas de várzea da Amazônia e habitats costeiros. Espécies florestais e de áreas abertas não são reciprocamente monofiléticas. De forma similar, em alguns casos, espécies pertencentes a um mesmo bioma não são proximamente relacionadas, o que sugere uma história complexa de diversificação na região. A utilização de dados de sítios emparelhados de seqüências de RNA não trouxe mudanças significativas nas topologias e inferências de tempo de divergência, possivelmente devido à baixa variação das hastes neste grau de divergência. 


\section{Abstract}

The family Accipitridae represents one of the largest radiations of modern birds, with species being found in a plethora of habitats around the world. Among the divisions proposed for the family in the past, the group of the buteonine hawks is one of the few that approximate monophyletic lineages, according to recent phylogenetic analyses. Besides occurring both in the New World and Old World, most buteonine hawk species are mainly found in Central and South America, what provides an opportunity to evaluate patterns and processes of diversification in both continental and local scales.

The main goals of this work were to infer phylogenetic relationships among species of buteonine hawks, analyze the evolution of migratory behaviour, and evaluate patterns and processes of diversification, especially in the Neotropical region. We obtained more than 7.000 base pairs of mitochondrial and nuclear DNA sequences from 51 species of buteonine hawks, what comprises the largest phylogenetic analysis of the group so far. Approximately one third of the total dataset was obtained from DNA sequences of 12S, tRNAVal and 16S, which are known to have paired sites that evolve in concert due to the presence of a secondary structure. Alternative analyses incorporating such information have been performed, as a way to evaluate the effects of secondary structure in the phylogenetic analyses. Since a model of secondary structure of $16 \mathrm{~S}$ of birds was not available so far, we build one based on comparative analysis of representatives of all modern avian orders.

The results suggest that the genera Buteo, Leucopternis and Buteogallus as currently accepted are not monophyletic, what stress a lack of concordance between current classification and the evolutionary history of this group. Five main lineages were found, and the most basal part of the topology is composed by mainly neotropical species, while the majority of neartic and Old World species were positioned in the most derived part of the tree. Together with divergence time estimates, those results suggest a long period of diversification in the Neotropics (possibly beginning in the Upper Miocene or Oligocene, and extending to the Pleistocene), with a latter colonization and diversification of the Neartics and Old World (possibly beginning between the Upper Oligocene or Pliocene, and extending to the Pleistocene). Migratory behaviour evolved several times, and may have contributed to diversification by means of exploitation of previously unavailable habitats as well as promotion of speciation in islands.

Lowland species disjunctions between each side of the Andes occurred four times, possible due to two vicariant events. The earliest disjunctions may have been caused by Andean orogeny, but no process could be clearly attributed to the two most recent speciations. Two lineages restricted to flooded habitats were found. The results suggest not only a long process of diversification in such habitats, independently of species of non-flooded habitats, but also a historical relationship between varzea forests in Amazonia and costal habitats. Similarly, species that occupy the same biome are not the closest relatives in several cases, what suggests a complex history of diversification in the Neotropical region. Inclusion of secondary structure information did not affect significantly phylogenetic and divergence time estimates, likely due to the low variation in stems in such level of divergence. 


\section{Capítulo 1}

\section{Introdução Geral}

Esta tese apresenta um estudo de sistemática molecular de um grupo de acipitrídeos distribuído por quase todo o mundo, os gaviões buteoninos. Foram realizadas reconstruções filogenéticas, estimativas de tempo de divergência e uma reconstrução de estados ancestrais, que basearam uma inferência sobre aspectos da diversificação do grupo, com ênfase na região Neotropical. Um modelo de estrutura secundária do rRNA 165 de aves foi construído, e junto a modelos do tRNAVal e 12S foram utilizados na avaliação do impacto da dependência de sítios destas seqüências nas reconstruções filogenéticas.

Nesta introdução serão abordados aspectos relacionados ao estudo da biogeografia histórica, uma breve introdução sobre padrões e processos de diversificação na região Neotropical, e por fim uma introdução sobre a ordem Falconiformes e a família Accipitridae, aos quais os gaviões buteoninos pertencem. Nos capítulos subseqüentes, serão introduzidos com mais detalhes aspectos relacionados a cada um destes estudos.

\section{A biogeografia e a sistemática no estudo da evolução}

Um dos fatos mais intrigantes sobre a diversidade biológica é a existência de padrões de distribuição particulares e não-aleatórios dos organismos sobre a Terra. A percepção da existência de comunidades de composição faunística e florística distintas de acordo com a localização geográfica, assim como a busca por explicações para tais padrões, é antiga, podendo ser encontrada em manuscritos do século XVIII (LINNAEUS, 1781). O desenvolvimento de expedições e coleções biológicas gerou já no século XIX a elaboração da divisão do planeta em regiões zoologicamente distintas (WALLACE, 1876), a proposição de fatores como clima, rios e topografia como obstáculos a dispersão de animais (WALLACE, 1852; 1876) e tipos de solos para vegetais (CANDOLLE, 1859), além de hipóteses sobre a importância de componentes geográficos na variação biológica (GLOGER, 1833; BERGMANN, 1847; ALLEN, 1877).

A descrição dos padrões atuais de distribuição e a formulação de hipóteses sobre processos históricos de diversificação culminou no desenvolvimento da biogeografia, disciplina que pode ser definida 
simplesmente como o estudo da distribuição dos organismos (CRISCl et al., 2003). Descobertas em disciplinas alheias a biologia estão entre os maiores propulsoras do desenvolvimento da biogeografia, o que reflete sua natureza multidisciplinar (CRISCl et al., 2003). No início do século XX, Alfred Wegener (1915) propôs a teoria da deriva continental, desafiando a idéia de estabilidade geológica predominante nos séculos anteriores; a crosta terrestre não seria estática, e embora tenha sido unida em um único bloco há cerca de 200 milhões de anos, teria gradualmente se fragmentado em blocos que se movimentam, processo que teria gerado a conformação moderna dos continentes.

A ampla aceitação da teoria de Wegener (1915) apenas na década de 60 (HUMPHRIES \& PARENTI, 1999) coincidiu temporalmente com o desenvolvimento da sistemática filogenética por Hennig (1966). Hennig propôs que as classificações deveriam refletir a história evolutiva dos táxons, que seriam inferidas com base na identificação de sinapomorfias (estados de caracteres derivados compartilhados), simplesiomorfias (estados de caracteres ancestrais compartilhados) e homoplasias (surgimentos independentes de um mesmo estado de caráter), ao invés de similaridades entre as espécies. Além da importância evidente da sistemática filogenética para a classificação, tornou-se também viável a geração de dados sobre a relação entre as áreas em que estas espécies estão distribuídas. Deste modo, de forma concomitante ao desenvolvimento da sistemática filogenética Croizat (1964) criou um novo paradigma: a hipótese da evolução sincrônica da Terra e dos organismos (HUMPHRIES \& PARENTI, 1999).

As distribuições dos organismos são dinâmicas e assumem configurações diversas, sendo afetadas constantemente por conseqüências diretas $e$ indiretas do clima e da topografia ao longo do tempo. A biogeografia ecológica estuda os processos que mantém as distribuições em períodos recentes, enquanto a biogeografia histórica avalia a importância de fatores passados na diversificação dos táxons e áreas (CRISCl et al., 2003). A biogeografia ecológica por si só não explica os padrões de diversidade e distribuição já que, por exemplo, similaridades entre clima e topografia de áreas distintas no globo não necessariamente levam a composições faunísticas e florísticas similares (HUMPHRIES \& PARENTI, 1999). Por outro lado, 
a biogeografia histórica não pode explicar a geração da diversidade sem considerar aspectos ecológicos recentes, que mantém as distribuições atuais (HUMPHRIES \& PARENTI, 1999).

Crisci et al. (2003) enumeram 9 classes de métodos de inferência da biogeografia histórica, entre eles Centros de Origem e Dispersão, Biogeografia Filogenética, Áreas Ancestrais, Panbiogeografia, Biogeografia Cladística, Análise de Parcimônia de Endemicidade, Métodos Baseados em Eventos, Filogeografia e Biogeografia Experimental. Estes métodos diferem entre si principalmente em relação ao uso ou não de filogenias nas estimativas, modelos explícitos de diversificação, e premissas como ocorrência de vicariância, dispersão e extinção (CRISCl et al., 2003).

Um dos objetivos comuns a todos os métodos biogeográficos é a inferência de relações entre áreas onde grupos monofiléticos diversos estão distribuídos (VAN VELLER et al., 2003). Métodos que utilizam hipóteses filogenéticas buscam padrões biogeográficos gerais por meio de comparação de hipóteses filogenéticas de grupos taxonômicos diversos que ocupam a mesma área, e as semelhanças e divergências entre as topologias são observadas. Associações positivas podem estar relacionadas ao efeito coletivo de um mesmo processo, afetando diversos grupos distintos de forma similar (vicariância), enquanto incongruência pode sugerir eventos de dispersão, extinção, ou um arcabouço temporal distinto na diversificação das diferentes linhagens (HUMPHRIES \& PARENTI, 1999).

O uso de métodos de inferência filogenética utilizando dados moleculares e genealogias de genes, i.e. biogeografia molecular (CRISCl et al., 2003) e métodos filogeográficos (AVISE et al., 1987), têm se expandido de forma crescente nos últimos anos devido ao desenvolvimento dos métodos analíticos, além da atual facilidade de obtenção de seqüências macromoleculares (DESALLE et al., 2002). Além das inferências das relações filogenéticas, dados moleculares podem ser utilizados em aproximações dos tempos de divergência entre linhagens, que embora sejam motivo de amplo debate (ARBOGAST et al., 2002), quando utilizadas com cautela adicionam um componente temporal às análises. Apesar das amplas possibilidades proporcionadas pelo uso de dados moleculares, a análise deste tipo de dado não está livre de obstáculos, como por exemplo: a existência bem 
documentada de numts, que consistem em cópias de genes mitocondriais presentes no núcleo (BENSASSON et al., 2001), que podem confundir inferências filogenéticas quando não detectados (SANDERSON \& SHAFFER, 2002); a possibilidade de composições de base heterogêneas entre as seqüências analisadas, o que pode gerar artefatos filogenéticos (GRUBER et al., 2007); e a presença de sítios correlacionados em determinados tipos de seqüências (e.g. DNA ribossômico), o que viola o princípio de independência de caracteres, premissa comum a todos os métodos filogenéticos (DIXON \& HILLIS, 1993). Análises filogenéticas utilizando moléculas devem considerar aspectos inerentes a este tipo de conjunto de dados, como forma de minimizar potenciais efeitos negativos não apenas na inferência das relações entre os táxons, como também em análises biogeográficas.

\section{Padrões e processos de diversificação na região Neotropical}

Dentre os diversos desafios da biologia evolutiva moderna, o entendimento da diversificação biológica na região Neotropical, que compreende a biota distribuída do sul do México ao sul da América do Sul, figura entre os de maior interesse e complexidade. As florestas de terras baixas neotropicais, em especial, albergam uma fauna que se destaca como uma das mais diversas de qualquer unidade biogeográfica do planeta (HAFFER, 1990). O numero total de espécies de aves que ocorrem na região Neotropical, por exemplo, é de aproximadamente 3.751, sendo destas 1.599 endêmicas (STOTZ et al., 1996). Além desta alta diversidade, uma grande proporção de espécies de aves apresenta distribuições restritas, apesar do alto potencial de dispersão proporcionada pela capacidade de vôo. Tais padrões de distribuição espacial são freqüentemente compartilhados por táxons pertencentes a grupos taxonômicos distintos, e a percepção de áreas ricas em endemismos com distribuições relativamente coincidentes foram denominadas como refúgios por HAFFER (1969) e áreas de endemismo por Cracraft (1985).

A tentativa de explicar estes padrões levou à formulação de diversos modelos, que propõem processos supostamente responsáveis pela geração 
e manutenção do conjunto único de características da biota neotropical (WALLACE，1852; HAFFER，1969; VANZOLINI \& WILLIAMS，1970; ENDLER，1982; SALO et al., 1986; TUOMISTO et al., 1995; MARROIG \& CERQUEIRA, 1997). Alguns dos primeiros estudos biogeográficos que contemplaram a biota neotropical (e.g. DARLINGTON JR., 1957) sugeriam que esta seria muito antiga e estável, o que propiciaria a manutenção de uma biota rica devido à baixas taxas de extinção e acúmulo de espécie. No entanto, atualmente o dinamismo geológico e climático têm sido valorizados, ao invés da estabilidade, como principais processos geradores de diversidade (SALO et al., 1986; WHITMORE \& PRANCE, 1987; BUSH, 1994; RASANEN et al., 1995; MARROIG \& CERQUEIRA, 1997; NORES, 1999). Entre as teorias formuladas como o intuito de explicar a diversificação neotropical figuram os modelos de Centros de Origem e Dispersão (REIG, 1984), Rios como Barreira (WALLACE, 1852), Gradientes Ecológicos (ENDLER, 1982), Dinâmica de Rios (SALO et al., 1986), Heterogeneidade Ambiental (TUOMISTO et al., 1995), Vicariância Geotectônica (NELSON \& PLATNICK, 1981), Teoria dos Refúgios (HAFFER, 1969; VANZOLINI \& WILLIAMS, 1970), e Hipótese da Laguna (MARROIG \& CERQUEIRA, 1997; NORES, 1999).

Estudos filogenéticos e filogeográficos contemplando aves neotropicais, em todos os níveis taxonômicos, representam uma oportunidade única para a descrição de padrões de descontinuidades biológicas, e caracterização espacial e temporal de diversificação. Como conseqüência, o acúmulo de análises desta natureza é de grande valor empírico para avaliações críticas de modelos de diversificação propostos, elaboração de novos modelos, teste de congruência entre grupos taxonômicos distintos, e conseqüente desenvolvimento do conhecimento dos processos que foram determinantes para a diversificação e manutenção da biota neotropical.

\section{A controversa ordem Falconiformes}

Os acipitrídeos pertencem à ordem Falconiformes, grupo de composição incerta e relações filogenéticas ainda mal definidas (STRESEMANN \& AMADON, 1979; AMADON \& BULL, 1988; SIBLEY \& AHLQUIST, 
1990; REMSEN JR. et al., 2007). Tradicionalmente são incluídas nesta ordem as famílias Accipitridae (águias, gaviões, e abutres do velho mundo), Pandionidae (águia pescadora), Sagittariidae (serpentário) e Falconidae (falcões e caracarás) (e. g. SICK, 1997). Alguns autores incluem ainda a família Cathartidae (abutres do novo mundo, WETMORE, 1960; BROWN \& AMADON, 1968; CRACRAFT, 1981; THIOLLAY, 1994), e as famílias Strigidae e Tytonidae (e. g. CRACRAFT, 1981) nesta ordem.

Existe pouco consenso sobre as relações dos Falconiformes com outras ordens de aves, e o próprio monofiletismo da ordem é questionado já em trabalhos clássicos (BROWN \& AMADON, 1968; JOLLIE, 1977). Esta problemática não se restringe apenas à ordem Falconiformes, já que a falta de consenso das relações entre ordens e famílias é generalizada dentro da Classe Aves (CRACRAFT et al., 2004). Este fato tem motivado um grande número de inferências filogenéticas, utilizando os mais diversos conjuntos de caracteres (VAN TUINEN et al., 2000; MAYR \& CLARKE, 2003; FAIN \& HOUDE, 2004; ERICSON et al., 2006; GIBB et al., 2007; LIVEZEY \& ZUSI, 2007).

O trabalho de Sibley e Ahlquist (1990), baseado na técnica de hibridação DNA-DNA, constituiu um dos primeiros esforços para a inferência das relações entre as linhagens de aves modernas com base em moléculas. Sibley e Alquist (1990) propõe, por exemplo, que a família Cathartidae seria mais proximamente relacionada aos Ciconiformes do que às famílias tradicionalmente incluídas na ordem Falconiformes, o que constitui uma das maiores controvérsias da sistemática ornitológica. Embora tenha contribuído de forma significativa para o delineamento de algumas relações, de forma geral a classificação proposta por estes autores é questionada devido a limitações da técnica, falta de métodos rigorosos para análise dos dados, e desenho experimental enviesado por pré-concepções de relações filogenéticas (CRACRAFT et al., 2004).

Estudos filogenéticos recentes abordando as relações das principais linhagens de aves, incluindo as famílias tradicionalmente incluídas da ordem Falconiformes, de modo geral apresentam topologias pouco resolvidas e com baixo suporte estatístico. Este padrão tem sido justificado como resultante de uma radiação rápida, o que pode ter gerado ramos curtos que dificultam análises filogenéticas (POE \& CHUBB, 2004; mas veja GIBB et al., 
2007 para opinião contrária). As análises moleculares mais resolvidas até o momento sugerem que: 1) a família Pandionidae é irmã da família Accipitridae (LERNER \& MINDELL, 2005; ERICSON et al., 2006; GIBB et al., 2007; GRIFFITHS et al., 2007); 2) a família Sagittariidae é irmã deste grupo (ERICSON et al., 2006; GRIFFITHS et al., 2007) e, finalmente, 3) a família Falconidae não é proximamente relacionados às famílias Accipitridae, Pandionidae e Sagittariidae (FAIN \& HOUDE, 2004; ERICSON et al., 2006). O estudo de Ericson et al. (2006), que apresenta uma das topologias moleculares mais resolvidas até o momento (apesar do grande número de politomias), sugere que a família Cathartidae seria mais proximamente relacionada às três últimas famílias do que a família Falconidae.

Recentemente Livezey e Zusi (2007) realizaram uma análise filogenética incluindo mais de 2600 caracteres morfológicos. Estes autores inferiram o monofiletismo de um clado contendo as famílias Accipitridae, Pandionidae, Falconidae, Sagittariidae e Cathartidae, com 100\% de suporte de bootstrap, sendo este clado irmão dos Strigiformes. Esta sugestão de proximidade filogenética entre aves de rapina diurnas e noturnas corrobora Mayr e Clarck (2003), que também utilizaram dados morfológicos. No entanto, os resultados deste último trabalho indicam que a ordem Falconiformes não seria monofilética, devido à maior proximidade de Accipitridae e Falconidae aos Strigiformes do que às famílias Sagittariidae e Cathartidae. Um dos resultados mais interessantes da análise de Livezey e Zusi (2007) é o agrupamento de Pandionidae e Falconidae como grupos irmãos, o que junto à inferência do monofiletismo da ordem contraria alguns trabalhos moleculares recentes (e. g. ERICSON et al., 2006; GIBB et al., 2007).

Estes resultados em conjunto sugerem que as divergências entre as linhagens principais de Aves são profundas, e não necessariamente refletem agrupamentos da taxonomia clássica. Além disso, existe conflito entre análises morfológicas e moleculares que merecem investigação (e. g. ERICSON et al., 2006; LIVEZEY \& ZUSI, 2007), e apenas uma grande quantidade de dados (e.g. dezenas de kilobases de seqüências, e milhares de caracteres morfológicos) e ampla amostragem taxonômica serão capazes de gerar maior resolução em inferências das relações das famílias tradicionalmente incluídas na ordem Falconiformes. A falta de monofiletismo da ordem, como 
sugerido por alguns dos trabalhos moleculares citados, indica ainda que resultados robustos surgirão apenas quando o problema não for dissociado da inferência das relações entre todas as ordens de aves modernas. Por este motivo, resultados de análises baseadas em amostragens taxonômicas parciais (LERNER \& MINDELL, 2005; GRIFFITHS et al., 2007) devem ser tomados com cautela na determinação de relações entre famílias e ordens. Como exposto nos parágrafos anteriores, a composição dos Falconiformes, assim como propostas de relações com outras ordens, são ainda provisórias. Por este motivo, foram aqui consideradas as famílias Pandionidae, Accipitridae, Sagittaridae e Falconidae como componentes da ordem Falconiformes, classificação congruente com a adotada Thiollay (1994), com exceção da exclusão da família Cathartidae. Os catartídeos foram aqui considerada como pertencente à ordem Cathartiformes (como adotado pelo COMITÊ BRASILEIRO DE REGISTROS ORNITOLÓGICOS, 2007).

\section{Família Accipitridae: diversidade e características}

A família Accipitridae figura como a mais rica da ordem Falconiformes em número de espécies, acumulando 237 espécies aceitas e distribuídas por quase todo o mundo, com exceção da Antártida (THIOLLAY, 1994). As espécies incluídas nesta família são caracterizadas como aves predadoras que apresentam bico e garras curvos, cerume e membros inferiores bem desenvolvidos, e visão apurada (THIOLLAY, 1994). Existe grande diversidade morfológica entre espécies da família; o menor acipitrídeo (Gampsonyx swainsonii) possui cerca de 25 centímetros de comprimento total, e massa entre 75 e 100 gramas, enquanto certos abutres do velho mundo (e.g. Gyps), podem alcançar mais de 12 kilos, e até 3 metros de envergadura de asas (THIOLLAY, 1994). Entre os tipos mais comuns de adaptações aerodinâmicas estão: aves florestais de asas curtas e arredondadas e cauda longa, como Spizaetus tyrannus e Accipiter bicolor; espécies de vôo predominante planado, de asas longas e largas, e cauda média a curta, como Buteo albicaudatus e Geranoetus melanoleucus; e finalmente caçadores de vôo rápido, de asas longas e estreitas, e cauda média como lctinia plumbea (SICK, 1997). 
A diversidade de presas consumidas pelos acipitrídeos inclui insetos, moluscos, anfíbios, peixes, répteis, mamíferos e outras aves (THIOLLAY, 1994). Embora a maioria das espécies seja estritamente carnívora, existem registros de consumo esporádico de frutos (e.g. Elanoides, Gypohierax) e carniça (SICK, 1997; FERGUSON-LEES \& CHRISTIE, 2001). A maior parte das espécies brasileiras consome principalmente invertebrados lem sua maioria artrópodes, SICK, 1997).

A América Latina acumula o maior número de espécies de acipitrídeos do mundo, e diversos gêneros são exclusivos ou predominantemente distribuídos na região Neotropical (e.g. Harpyhaliaetus, Morphnus, Geranospiza, Chondrohierax, Helicolestes, Harpagus, Rostrhamus, Leucopternis, Buteogallus e Harpia, SICK 1997). No entanto, pouco se conhece sobre a biologia básica de grande parte dos acipitrídeos neotropicais (AMADON, 1982; BIERREGAARD JR, 1995; SICK, 1997), o que prejudica, por exemplo, a compreensão de aspectos da história evolutiva das espécies, além da elaboração de projetos de conservação (BIERREGAARD JR, 1995). A necessidade de estudos adicionais é reforçada pelo número crescente de espécies incluídas em listas de espécies ameaçadas de extinção, como atualmente no Brasil Leucopternis lacernulatus, Harpyhaliaetus coronatus e Circus cinereus.

Embora existam diversas revisões clássicas envolvendo acipitrídeos (e.g. RIDGWAY, 1876; JOHNSON \& PEETERS, 1963; AMADON, 1964; BROWN \& AMADON, 1968; AMADON, 1982), a maior parte das decisões taxonômicas aceitas até o presente têm sido baseadas em semelhanças de padrões de plumagem, e impressões de comportamento em campo (OLSON, 1985), o que muitas vezes pode ocultar a história evolutiva das linhagens. Este problema pode ser agravado pela convergência de caracteres de plumagem (THIOLLAY, 1994; veja exemplo em Passeriformes em OMLAND \& LANYON, 2004) e polimorfismos intra-específicos, muito comuns entre acipitrídeos (FERGUSON-LEES \& CHRISTIE, 2001). A necessidade de estudos filogenéticos utilizando dados moleculares e morfológicos é refletida até mesmo na dificuldade de alocação do relativamente rico registro fóssil da família (OLSON, 1985). Por estes motivos, grande parte da classificação entre 
os acipitrídeos é ainda considerada provisória (FERGUSON-LEES \& CHRISTIE, 2001).

A diversidade biológica dos acipitrídeos é comumente compartimentalizada em divisões que agrupam espécies utilizando critérios de semelhança morfológica e ecológica (THIOLLAY, 1994). Esta classificação inclui os kites, águias pescadoras, abutres do velho mundo, harriers, açores, gaviões buteoninos, águias de "bota", e águias neotropicais (BROWN \& AMADON, 1968; THIOLLAY, 1994), divisões não que necessariamente implicam ancestralidade comum direta das espécies incluídas (THIOLLAY, 1994). Embora alguns autores reconhecem subfamílias de acipitrídeos (PETERS, 1931; STRESEMANN \& AMADON, 1979; DICKINSON, 2003), de forma geral assume-se que o status de conhecimento das relações entre os gêneros e espécies é insuficiente para a utilização de tais divisões (AMADON \& BULL, 1988; THIOLLAY, 1994).

Embora estudos filogenéticos incluindo espécies de Accipitridae ainda sejam escassos quando comparados a outros grupos (e.g. famílias de Passeriformes), o número de inferências filogenéticas tem crescido de forma exponencial na última década. Um padrão comum que têm emergido nestes trabalhos é a falta de correspondência entre a classificação tradicional e as relações filogenéticas inferidas. Em níveis taxonômicos mais elevados, Lerner e Mindell (2005) e Griffiths et al. (2007) sugeriram que grande parte das divisões ou subfamílias propostas até o momento não correspondem a clados monofiléticos. Já entre gêneros, é possível citar, por exemplo, o falta de monofiletismo de Buteo (RIESING et al., 2003), Buteogallus e Leucopternis (AMARAL et al., 2006), Aquila, Spizaetus e Hieraaetus (HELBIG et al., 2005), 2005). Estes resultados tomados em conjunto indicam a necessidade de estudos filogenéticos adicionais em todos os níveis taxonômicos na família, que serão úteis para alinhar a classificação de espécies, gêneros e subfamílias com a história evolutiva do grupo e, principalmente, permitir a descrição de padrões e processos envolvidos na diversificação destas aves. 


\section{Referências Bibliográficas}

ALLEN, J. A. The influence of physical conditions in the genesis of species. Radical Review, v. 1, p. 108-140. 1877.

AMADON, D. Taxonomic notes on birds of prey. American Museum Novitates, v. 2166, p. 1-24. 1964.

A revision of the sub-buteonine hawks (Accipitridae, Aves). American Museum Novitates, v. 2741, p. 1-20. 1982.

AMADON, D., BULL, J. Hawks and owls of the world: a distributional and taxonomic list. Western Foundation of Vertebrate Zoology, v. 3, n. 4, p. 295-357. 1988.

AMARAL, F. S. R., MILLER, M. J., SILVEIRA, L. F., BERMINGHAM, E., WAJNTAL, A. Polyphyly of the hawk genera Leucopternis and Buteogallus (Aves, Accipitridae): multiple habitat shifts during the Neotropical buteonine diversification. BMC Evolutionary Biology, v. 6, p. 10. 2006.

ARBOGAST, B. S., EDWARDS, S. V., WAKELEY, J., BEERLI, P., SLOWINSKI, J. B. Estimating divergence times from molecular data on phylogenetic and population genetics timescales. Annual Review of Ecology and Systematics, v. 33, p. 707-740. 2002.

AVISE, J. C., ARNOLD, J., BALL, R. M., BERMINGHAM, E., LAMB, T., NEIGEL, J. E., REEB, C. A., SAUNDERS, N. C. Intraspecific phylogeography: the mitochondrial DNA bridge between population genetics and systematics. Annual Review of Ecology and Systematics, v. 18, p. 489-522. 1987.

BENSASSON, D., ZHANG, D., HARTL, D., HEWITT, G. Mitochondrial pseudogenes: evolution's misplaced witnesses. Trends in Ecology and Evolution, v. 16, n. 6, p. 314-321. 2001.

BERGMANN, C. Über die Verhältnisse der wärmeökonomie der Thiere zu ihrer Grösse. Göttinger Studien v. 3, n. 1, p. 595-708. 1847.

BIERREGAARD JR, R. O. The biology and conservation status of Central and South American Falconiformes: a survey of current knowledge. Bird Conservation International, v. 5, p. 329-345. 1995.

BROWN, L., AMADON, D. Eagles, hawks and falcons of the world. London: Country Life Books. 1968. 1 v.

BUSH, M. B. Amazonian speciation: a necessarily complex model. Journal of Biogeography, v. 21, n. 1, p. 5-17. 1994.

CANDOLLE, A. L. P. P. On the causes which limit vegetable species towards the north, in Europe and similar regions. Annual Report of the Board of Regents of the Smithsonian Institution for the Year 1858, p. 237-245. 1859. 
COMITÊ BRASILEIRO DE REGISTROS ORNITOLÓGICOS. Listas das aves do Brasil. Disponível em: http://www.cbro.org.br. Acesso em: 16 de agosto de 2007

CRACRAFT, J. Toward a phylogenetic classification of the recent birds of the world (class Aves). The Auk, v. 98, n. 4, p. 681-714. 1981.

. Historical biogeography and patterns of differentiation within the South American avifauna: areas of endemism. Ornithological Monographs, v. 36, p. 49-84. 1985.

CRACRAFT, J., BARKER, F. K., BRAUN, M., HARSHMAN, J., DYKE, G. J., FEINSTEIN, J., STANLEY, S., CIBOIS, A., SCHIKLER, P., BERESFORD, P., GARCÍA-MORENO, J., SORENSON, M. D., YURI, T., MINDELL, D. P. Phylogenetic relationships among modern birds (Neornithes): toward an avian tree of life. In: CRACRAFT, J. e DONOGHUE, M. J. (org). Assembling the tree of life. New York: Oxford University Press, 2004. p. 468-489.

CRISCl, J. V., KATINAS, L., POSADAS, P. Historical Biogeography: an introduction. Cambridge: Harvard University Press. 2003.

CROIZAT, L. Space, time and form: the biological synthesis. Caracas: Leon Croizat. 1964.

DARLINGTON JR., P. J. Zoogeography: the geographical distribution of animals. New York: Wiley. 1957.675 p.

DESALLE, R., GIRIBET, G., WHEELER, W. Techniques in molecular systematics and evolution. Basel: Birkhäuser Verlag. 2002. 407 p.

DICKINSON, E. C. The Howard and Moore Complete Checklist of the Birds of the World. $3^{\circ}$ ed. London: Christopher Helm. 2003. 1040 p.

DIXON, M. T., HILLIS, D. M. Ribosomal RNA secondary structure: compensatory mutations and implications for phylogenetic analysis. Molecular Biology and Evolution, v. 10, n. 1, p. 256-267. 1993.

ENDLER, J. A. Problems in distinguishing historical from ecological factors in biogeography. Integrative and Comparative Biology, v. 22, n. 2, p. 441-452. 1982.

ERICSON, P. G., ANDERSON, C. L., BRITTON, T., ELZANOWSKI, A., JOHANSSON, U. S., KALLERSJO, M., OHLSON, J. I., PARSONS, T. J., ZUCCON, D., MAYR, G. Diversification of Neoaves: integration of molecular sequence data and fossils. Biology Letters, v. 2, p. 543-547. 2006.

FAIN, M. G., HOUDE, P. Parallel radiations in the primary clades of birds. Evolution, v. 58, n. 11, p. 2558-2573. 2004.

FERGUSON-LEES, J., CHRISTIE, D. A. Raptors of the World. Boston: Houghton Mifflin. 2001.992 p. 
GIBB, G. C., KARDAILSKY, O., KIMBALL, R. T., BRAUN, E. L., PENNY, D. Mitochondrial genomes and avian phylogeny: complex characters and resolvability without explosive radiations. Molecular Biology and Evolution, $v$. 24, n. 1, p. 269-280. 2007.

GLOGER, C. W. L. Das Abändern der Vögel durch Einfluss des Klima's. Breslau: August Schulz. 1833. 159 p.

GRIFFITHS, C. S., BARROWCLOUGH, G. F., GROTH, J. G., MERTZ, L. A. Phylogeny, diversity, and classification of the Accipitridae based on DNA sequences of the RAG-1 exon. Journal of Avian Biology, v. 38, n. 5, p. 587-602. 2007.

GRUBER, K. F., VOSS, R. S., JANSA, S. A. Base-compositional heterogeinity in the RAG-1 Locus among Didelphid Marsupials: implications for phylogenetic inference and the evolution of GC content. Systematic Biology, v. 56, n. 1, p. 83-96. 2007.

HAFFER, J. Speciation in Amazonian Forest Birds. Science, v. 165, n. 3889, p. 131-137. 1969.

Avian species richness in tropical South America. Studies on Neotropical Fauna \& Environment, v. 25, n. 3, p. 157-183. 1990.

HELBIG, A. J., KOCUM, A., SEIBOLD, I., BRAUN, M. J. A multi-gene phylogeny of aquiline eagles (Aves: Accipitriformes) reveals extensive paraphyly at the genus level. Molecular Phylogenetics and Evolution, v. 35, n. 1, p. 147-164. 2005.

HENNIG, W. Phylogenetic systematics. Urbana: University of Illinois Press. 1966.

HUMPHRIES, C. J., PARENTI, L. R. Cladistic Biogeography: interpreting patterns of plant and animal distributions. Oxford: Oxford University Press. 1999. $200 \mathrm{p}$.

JOHNSON, N. K., PEETERS, H. J. The systematic position of certain hawks in the genus Buteo. Auk, v. 80, n. 4, p. 417-446. 1963.

JOLLIE, M. A Contribution to the Morphology and Phylogeny of the Falconiformes. Department of Biology, University of Chicago. 1977.

LERNER, H. R., MINDELL, D. P. Phylogeny of eagles, Old World vultures, and other Accipitridae based on nuclear and mitochondrial DNA. Molecular Phylogenetics and Evolution, v. 37, n. 2, p. 327-346. 2005.

LINNAEUS, C. Selected dissertations from the Amoenitates Academicae. London: Robeson and Robeson. 1781.

LIVEZEY, B. C., ZUSI, R. Higher-order phylogeny of modern birds (Theropoda, Aves: Neornithes) based on comparative anatomy. II. Analysis and discussion. Zoological Journal of the Linnean Society, v. 149, n. 1, p. 1-95. 2007. 
MARROIG, G., CERQUEIRA, R. Plio-Pleistocene South American history and the Amazon Lagoon Hypothesis: a piece in the puzzle of Amazonian diversification. Journal of Comparative Biology, v. 2, p. 103-119. 1997.

MAYR, G., CLARKE, J. The deep divergences of neornithine birds: a phylogenetic analysis of morphological characters. Cladistics, v. 19, n. 6, p. 527-553. 2003.

NELSON, G., PLATNICK, N. I. Systematics and Biogeography: Cladistics and Vicariance. New York: Columbia University Press. 1981.

NORES, M. An alternative hypothesis for the origin of Amazonian bird diversity. Journal of Biogeography, v. 26, n. 3, p. 475-485. 1999.

OLSON, S. L. The fossil record of birds. In: FARNER, D. S., KING, J. R. e PARKES, K. C. (org). Avian biology. Orlando: Academic Press, 1985. vol.8 p. 80-238.

OMLAND, K. E., LANYON, S. M. Recontructing plumage evolution in orioles (Icterus): repeated convergence and reversal in patterns. Evolution, v. 54, n. 6 , p. $2119-2133.2004$.

PETERS, J. L. Check-list of birds of the world. Vol. 1. Harvard University Press. 1931.

POE, S., CHUBB, A. L. Birds in a bush: five genes indicate explosive evolution of avian orders. Evolution, v. 58, n. 2, p. 404-415. 2004.

RASANEN, M. E., LINNA, A. M., SANTOS, J. C. R., NEGRI, F. R. Late Miocene Tidal Deposits in the Amazonian Foreland Basin. Science, v. 269, n. 5222, p. 386-390. 1995.

REIG, O. A. Distribuição geográfica e história evolutiva dos roedores muroideos sulamericanos (Cricetidae: Sigmodontinae). Revista Brasileira de Genética, v. 7, p. 333-365. 1984.

REMSEN JR., J. V., JARAMILLO, A., NORES, M., PACHECO, J. F., ROBBINS, M. B., SCHULENBERG, T. S., STILES, F. G., SILVA, J. M. C., STOTZ, D. F., ZIMMER, K. J. A classification of the bird species of South America. American Ornithologists' Union. Disponivel em: http://www.museum.lsu.edu/ Remsen/SACCBaseline.html. Acesso em: 21 de dezembro de 2007

RIDGWAY, R. Studies of the American Falconidae. Dept. of the Interior, United States Geological and Geographical Survey of Territories. 1876.

RIESING, M. J., KRUCKENHAUSER, L., GAMAUF, A., HARING, E. Molecular phylogeny of the genus Buteo (Aves: Accipitridae) based on mitochondrial marker sequences. Molecular Phylogenetics and Evolution, v. 27, n. 2, p. 328342. 2003. 
SALO, J., KALLIOLA, R., HAKKINEN, I., MAKINEN, Y., NIEMELA, P., PUHAKKA, M., COLEY, P. D. River dynamics and the diversity of Amazon lowland forest. Nature, v. 322, p. 254-258. 1986.

SANDERSON, M. J., SHAFFER, H. B. Troubleshooting molecular phylogenetic analyses. Annual Review of Ecology and Systematics, v. 33, p. 49-72. 2002.

SIBLEY, C. G., AHLQUIST, J. E. Phylogeny and classification of birds. New Haven: Yale University Press. 1990.

SICK, H. Ornitologia Brasileira. Rio de Janeiro: Nova Fronteira. 1997. 912 p.

STOTZ, D. F., FITZPATRICK, J. W., PARKER III, T. A., MOSKOVITS, D. K. Neotropical Birds: Ecology and Conservation. Chicago: University of Chicago Press. 1996. $502 \mathrm{p}$.

STRESEMANN, E., AMADON, D. Order Falconiformes. In: MAYR, E. e COTTREL, G. W. (org). Check-list of birds of the world. Cambridge: Museum of Comparative Zoology, 1979. vol.1 p. 271-425.

THIOLLAY, J. M. Family Accipitridae (hawks and eagles). In: DEL HOYO, J. M. (org). Handbook of the birds of the world: New World vultures to guineafowl. Barcelona: Lynx Edicions, 1994. vol.2 p. 52-205.

TUOMISTO, H., RUOKOLAINEN, K., KALLIOLA, R., LINNA, A., DANJOY, W., RODRIGUEZ, Z. Dissecting Amazonian Biodiversity. Science, v. 269, n. 5220, p. 63-66. 1995.

VAN TUINEN, M., SIBLEY, C. G., HEDGES, S. B. The Early History of Modern Birds Inferred from DNA Sequences of Nuclear and Mitochondrial Ribosomal Genes. Molecular Biology and Evolution, v. 17, p. 451-457. 2000.

VAN VELLER, M. G. P., BROOKS, D. R., ZANDEE, M. Cladistic and phylogenetic biogeography: the art and the science of discovery. Journal of Biogeography, v. 30, n. 3, p. 319-329. 2003.

VANZOLINI, P. E., WILLIAMS, E. E. South American anoles: the geographic differentiation and evolution of the Anolis chrysolepis species group (Sauria, Iguanidae). Arquivos de Zoologia do Estado de São Paulo, v. 19, n. 1-298. 1970.

WALLACE, A. R. On the monkeys of the Amazon. Proceedings of the Zoological Society of London, v. 20, p. 107-110. 1852.

The geographical distribution of animals with a study of the relations of living and extinct faunas as elucidating the past changes of the earth's surface. London: Macmillan. 1876.

WEGENER, A. Die entstehung der kontinente und ozeane. Braunschweig: Vieweg \& Sohn. 1915. 
WETMORE, A. A Classification for the birds of the world. Smithsonian Miscellaneous Collections, v. 139, p. 1-37. 1960.

WHITMORE, T. C., PRANCE, G. T. Biogeography and quaternary history in tropical America. Oxford: Clarendon Press. 1987. 
Capítulo 2

Inferência filogenética e biogeografia histórica dos gaviōes buteoninos (Aves, Accipitridae): padrões e processos de diversificação em um grupo ecologicamente diverso e amplamente distribuído 


\section{Introdução}

A família Accipitridae figura como a quarta maior entre aves nãoPasseriformes, com 237 espécies, e representa uma das mais bem-sucedidas radiações de aves atuais. Espécies de acipitrídeos podem ser encontradas em todo o planeta exceto na Antártida, ocupando todos os habitats terrestres (THIOLLAY, 1994). A percepção da alta diversidade morfológica e ecológica dos acipitrídeos levou à tentativas de compartimentalização desta variação, com base em similaridades de plumagem, ecologia e comportamento (e.g. harriers, kites, booted eagles, THIOLLAY 1994). No entanto, grande parte da classificação tradicional adotada para os acipitrídeos parece não corresponder a agrupamentos monofiléticos de acordo com análises filogenéticas recentes, tanto entre gêneros (e. g. RIESING et al., 2003; HELBIG et al., 2005; AMARAL et al., 2006) como em níveis taxonômicos mais profundos (LERNER \& MINDELL, 2005; GRIFFITHS et al., 2007). Estes resultados ressaltam a importância de inferências filogenéticas para a construção de um novo cenário sobre o entendimento das relações, assim como dos padrões e processo de diversificação, em todos os níveis taxonômicos na família.

Entre os agrupamentos de espécies propostos previamente a estudos filogenéticos, o grupo dos gaviões buteoninos figura entre os poucos que se aproximam em composição a clados monofiléticos (LERNER \& MINDELL, 2005). Reconhecidos por alguns autores como subfamília Buteoninae (FRIEDMANN, 1950; GROSSMAN \& HAMLET, 1964; LERNER \& MINDELL, 2005), OS gaviões buteoninos são representados pelo gênero Buteo, que inclui aproximadamente 28 espécies (THIOLLAY, 1994) encontradas por todo o mundo (exceto na Austrália e na Antártida), além de diversas espécies tidas como proximamente relacionadas a Buteo, incluídas em um grupo denominado gaviões sub-buteoninos (AMADON, 1982). Esta última divisão contém os gêneros predominantemente neotropicais Buteogallus, Parabuteo, Asturina, Leucopternis, Busarellus, Geranoaetus, Geranospiza e Harpyhaliaetus, além dos gêneros Butastur e Kaupifalco do Velho Mundo. $O$ posicionamento basal destes gêneros à maioria das espécies de Buteo, no entanto, sugere o parafiletismo do grupo dos gaviões sub-buteoninos 
(RIESING et al., 2003; AMARAL et al., 2006; LERNER et al., no prelo). Por outro lado, o reconhecimento desta última divisão na taxonomia clássica ressalta a percepção, antes mesmo da utilização de métodos de reconstrução histórica, de algumas das linhagens principais de gaviões buteoninos (AMADON, 1982).

A maioria das espécies de gaviões buteoninos encontra-se no Novo Mundo, em especial na região Neotropical, habitando ecossistemas diversos como florestas (e.g. espécies atualmente incluídas no gênero Leucopternis), manguezais (e.g. Buteogallus aequinoctialis), savanas (e.g. Buteogallus meridionalis) e desertos (e.g. Parabuteo unicinctus). Esta alta diversidade não está distribuída apenas em terras continentais, e algumas espécies são de ocorrência exclusiva a ilhas de origem tanto vulcânica (como Buteo galapagoensis, Galápagos, e Buteo solitarius, Havaí) como continental (Buteo ridgwayi, República Dominicana). Outra característica ímpar deste grupo é a altíssima capacidade de dispersão, o que desafia modelos de diversificação dada a ampla distribuição e baixa importância de obstáculos naturais como rios e cadeias de montanhas para a geração de condições de alopatria para muitas destas espécies (AMARAL et al., 2006). Um exemplo extremo da capacidade de deslocamentos extensivos em espécies de gaviões buteoninos é realização de movimentos sazonais de longa distância, tanto no Velho Mundo como no Novo Mundo. No Novo Mundo três espécies de gaviões buteoninos são migrantes completos de longa distância, estabelecendo-se todos os anos na região Neotropical durando o inverno boreal (Buteo swainsoni, Buteo platypterus e Ictinia mississipiensis). Apesar da existência de hipóteses sobre a evolução do comportamento migratório entre gaviões buteoninos (BILDSTEIN, 2004), estes aspectos permanecem pouco explorados com base em inferências filogenéticas. Hipóteses sobre o relacionamento de um grupo, no entanto, são peças fundamentais para o entendimento do comportamento migratório, por este ser um componente histórico da evolução do grupo (CHESSER \& LEVEY, 1998; ZINK, 2002; KONDO \& OMLAND, 2007).

A reconstrução da história evolutiva dos gaviões buteoninos representa, portanto, uma oportunidade de análise de padrões e processos de diversificação de aves em escala continental, por apresentar alta 
diversidade de espécies e distribuição na maior parte do planeta. Por outro lado, estimativas de tempo de divergência nunca foram calculadas para o grupo, e estas informações podem ser importantes para uma análise de padrões e processos de diversificação. Em uma escala mais fina, estas inferências são de especial interesse para o entendimento da diversificação na região Neotropical, onde a maior diversidade de espécies de gaviões buteoninos é encontrada. Embora um número crescente de estudos filogenéticos e filogeográficos de aves neotropicais esteja construindo um corpo de evidência substancial para a compreensão dos processos de diversificação na região (e. g. BRUMFIELD, 2005; RIBAS et al., 2005; RIBAS et al., 2006; RIBAS et al., 2007), a grande maioria destes trabalhos concentra-se na análise de linhagens estritamente florestais (mas veja exemplos de exceção em ALEIXO, 2002; RIBAS \& MIYAKI, 2004; BRUMFIELD \& EDWARDS, 2007). Desta forma, a história da diversificação de aves ocupando distintos ecossistemas permanece ainda pouco explorada, e a ocorrência de espécies de gaviões buteoninos em uma variedade de habitats pode contribuir para 0 entendimento da diversificação tanto em biomas florestais como nãoflorestais da região Neotropical.

As relações filogenéticas entre gaviões buteoninos têm sido amplamente exploradas nos últimos 5 anos por diversos autores (RIESING et al., 2003; LERNER \& MINDELL, 2005; AMARAL et al., 2006; LERNER et al., no prelo). Riesing et al. (2003) utilizando dados mitocondriais (subunidade 6 do $\mathrm{NADH}$ e região pseudo-controladora) e ampla amostragem taxonômica de espécies do gênero Buteo, além de componentes dos gêneros Buteogallus, Parabuteo, Busarellus e Geranoaetus, foram os primeiros a sugerir o polifiletismo do gênero Buteo (apesar do monofiletismo das espécies do Velho Mundo), além do posicionamento basal de gêneros neotropicais em relação a Buteo. Estes autores também sugeriram que Kaupifalco não seria proximamente relacionado ao grupo. Já em um nível taxonômico mais alto, Lerner e Mindell (2005) realizaram uma análise das relações entre 51 gêneros de acipitrídeos (incluindo 13 espécies de gaviões buteoninos) utilizando dados mitocondriais e nucleares (citocromo b, subunidade 2 do NADH e íntron 7 do beta fibrinogênio), que sugeriu o monofiletismo dos gaviões buteoninos, com exceção da inclusão de Rosthramus no grupo. Entre outros 
achados importantes desta análise estão o relacionamento irmão entre Ictinia aos gaviões buteoninos, que por sua vez agruparam como irmãos de um clado contendo espécies de Haliaeetus e lcthyophaga. Três espécies de Leucopternis foram amostradas, e foi sugerido o agrupamento mais próximo de L. Kuhli e L. melanops a Buteo buteo e Buteo jamaicensis, do que a Leucopternis albicollis.

Amaral et al. (2006) apresentaram uma análise incluindo pela primeira vez todas as dez espécies conhecidas de Leucopternis, além de representantes dos gêneros Buteo, Parabuteo, Buteogallus, Harpyhaliaetus, Busarellus e Geranospiza. Baseando-se em dados mitocondriais (subunidade 6 do NADH, subunidades 8 e 6 da ATP sintetase, subunidade 125 do RNA ribossômico), estes autores inferiram o polifiletismo dos gêneros Leucopternis e Buteogallus, assim como o delineamento das relações entre os gêneros de gaviões buteoninos neotropicais. Neste trabalho foram encontradas mudanças múltiplas de habitat entre linhagens e espécies proximamente relacionadas, indicando alta plasticidade ecológica durante a evolução do grupo, além da pouca concordância entre padrões gerais de plumagem e relações filogenéticas.

Lerner, Klaver e Mindell (no prelo), utilizando mais de 3000 pares de bases (pb) mitocondriais e nucleares (citocromo b, subunidade 2 do NADH, intron 7 do beta fibrinogênio e subunidade 6 do NADH) realizaram análises filogenéticas incluindo todas as espécies de gaviões sub-buteoninos e espécies selecionadas do gênero Buteo. Entre os achados mais importantes encontram-se: a mistura de haplótipos entre Leucopternis occidentalis e subespécies trans-andinas de Leucopternis albicollis; a maior proximidade de Leucopternis albicollis albicollis a Leucopternis polionotus do que a outras subespécies de L. albicollis; o relacionamento irmão de espécies do gênero Butastur a todos os gaviões buteoninos; além da corroboração de resultados apresentados em análises anteriores como o polifiletismo de Buteo, Leucopternis e Buteogallus, e relações entre gêneros de gaviões subbuteoninos (RIESING et al., 2003; AMARAL et al., 2006). Apesar da ampla amostragem taxonômica, o conjunto completo de espécies amostradas não foi analisado simultaneamente, e as seqüências utilizadas não foram 
suficientes para a resolução de um grande número de nós, dada a predominância de genes mitocondriais de evolução rápida.

O objetivo deste capítulo é: 1) inferir uma topologia bem resolvida das relações entre espécies de gaviões buteoninos, com base na maior amostragem genética e taxonômica até o presente, 2) analisar a evolução do comportamento migratório entre os gaviões buteoninos, 3) explorar aspectos da biogeografia histórica do grupo com ênfase nas espécies neotropicais, baseando-se nas relações filogenéticas e estimativas de tempo de divergência, e 4) propor uma classificação em nível genérico que reflita a história evolutiva do grupo. 


\section{Material e Métodos}

\subsection{Amostragem taxonômica e genética}

Cento e cinco indivíduos pertencentes a 54 espécies de acipitrídeos foram seqüenciados (Anexo A), o que representa o estudo filogenético mais inclusivo do grupo até o presente. Deste total, 78 indivíduos foram representados por amostras frescas de tecido rico em DNA mitocondrial (pena, músculo ou vísceras), e 81 amostras estão associadas a espécimes testemunhos. São aqui reconhecidos como gaviões buteoninos além do gênero Buteo, que inclui espécies do Novo Mundo e do Velho Mundo, os gêneros exclusivos do Novo Mundo (NM) Asturina (recentemente incluído em Buteo, REMSEN Jr. 2007), Busarellus, Buteogallus, Leucopternis, Geranoaetus, Geranospiza, Harpyhaliaetus, Parabuteo, Rostrhamus e Ictinia (AMADON, 1982; LERNER \& MINDELL, 2005; LERNER et al., no prelo), além do gênero Butastur, restrito ao Velho Mundo (VM) (AMADON, 1982; LERNER et al., no prelo). Apesar de Kaupifalco (VM) ser considerado um gavião buteonino por Amadon (1982), este gênero não foi incluído por não ser proximamente relacionado ao grupo (RIESING et al., 2003; LERNER et al., no prelo). As duas espécies do gênero neotropical Harpagus, não amostradas em nenhum estudo filogenético até o presente, foram utilizados como forma de testar a inclusão destes táxons entre os gaviões buteoninos.

A nomenclatura utilizada para espécies do Novo Mundo foi a da American Ornithologists' Union (América do SUl: REMSEN JR. et al. 2007; América Central e América do Norte: AMERICAN ORNITHOLOGISTS' UNION, 1998, com modificações de BANKS et al. 2006 e BANKS et al. 2007). A nomenclatura das espécies do Velho Mundo adota foi a de Thiollay (1994), mas considerando Buteo japonicus e Buteo refectus como espécies plenas (RIESING et al., 2003; KRUCKENHAUSER et al., 2004). Com base nestas definições, a amostragem do presente trabalho incluiu todas as espécies de gaviões buteoninos do Novo Mundo com exceção de Buteo poecilochrous e Buteogallus gundlachii, e do Velho Mundo com exceção de Buteo oreophilus, Buteo brachypterus, Buteo archeri e espécies do gênero Butastur. A espécie neotropical Helicolestes hamatus, tida por alguns autores como 
proximamente relacionada a Rostrhamus sociabilis (AMADON, 1964), e desta forma possivelmente um gavião buteonino de acordo com a definição aqui utilizada, também não foi incluída. Quando possível, dois ou mais indivíduos de cada espécie foram incluídos. Todas as árvores filogenéticas foram enraizadas com a espécie norte-americana Haliaeetus leucocephalus, pertencente ao clado irmão de todos os gaviões buteoninos (LERNER \& MINDELL, 2005; LERNER et al., no prelo).

Foram obtidas seqüências de DNA completas dos marcadores mitocondriais subunidade 12S do RNA ribossômico (12S, aproximadamente $970 \mathrm{pb})$, RNA transportador valina (tRNAVal, aproximadamente 7lpb), subunidade 16S do RNA ribossômico (16S, aprox. 1600 pb), subunidades 8 e 6 da ATP sintetase (ATP8/6, 842 pb), subunidade 6 do NADH (ND6, 519 pb) e subunidade 2 do NADH (ND2, 1041 pb), além de seqüências parciais do gene mitocondrial citocromo B (CYTB, 1077 pb) e dos nucleares íntron 3 do lactato desidrogenase (LDH, aproximadamente 575 pb) e íntron 5 do Beta fibrinogênio (FIB5, 500 bp), totalizando mais de 7000pb. Estes marcadores foram selecionados por serem úteis na resolução de nós derivados e basais, devido à taxas de evolução distintas.

\subsection{Extração, amplificação, purificação e seqüenciamento de DNA}

A extração de DNA foi realizada a partir de amostras de músculo, fígado, pena ou sangue utilizando o kit de extração DNeasy (Quiagen Inc.) de acordo com instruções do fabricante, ou protocolo de fenol-clorofórmio modificado a partir de Bruford et al. (1992). Este último protocolo foi executado em tubos de 1,5 ml, adicionando-se $300 \mu \mathrm{l}$ de TNE, $30 \mu \mathrm{l}$ de Tris $1 \mathrm{M}$ ph 7.5, $8 \mu \mathrm{l}$ de SDS $25 \%$ e $20 \mu \mathrm{l}$ de proteinase $\mathrm{K}(25 \mathrm{mg} / \mathrm{ml})$. Foram então adicionados aproximadamente $2 \mathrm{~mm}^{3}$ de tecido a esta solução de digestão, que foi incubada por aproximadamente 18 horas à temperatura de $55^{\circ} \mathrm{C}$. Após a incubação, foi adicionado um volume de fenol: clorofórmio: álcool isoamílico (25: 24: 1), e a foi solução foi homogeneizada e centrifugada por 10 minutos a velocidade de 12.000 RPM. O sobrenadante foi transferido para um novo tubo, e o DNA foi precipitado por meio da adição de aproximadamente $1 \mathrm{ml}$ de etanol 95\%. Esta solução foi centrifugada por mais 
20 minutos a 12.000 RPM. O sobrenadante foi novamente retirado, e então foram adicionados $300 \mu \mathrm{l}$ de etanol $70 \%$. Esta solução foi centrifugada por mais 5 minutos a 12.000 RPM. O sobrenadante foi descartado, e o precipitado foi seco por meio de centrifugação a vácuo por cerca de 5 minutos. A elvição do DNA foi realizada adicionando-se de 50 a $200 \mu$ de TE. A solução de DNA eluída foi avaliada quanto à integridade e concentração por meio de eletroforese em gel de agarose 1 \% com auxílio de marcadores de peso molecular, ou por meio de quantificação no espectrofotômetro Nanodrop ND-1000 (Nanodrop Technologies). No caso de extração de pele de artelhos (toe pads) e penas, foram adicionados $30 \mu \mathrm{g}$ de dithiothreitol ao tampão de extração, como forma de facilitar a digestão.

As amplificações dos fragmentos foram realizadas por meio da reação em cadeia da polimerase (PCR), utilizando termociclador TC2400 (Applied Biosystems), PTC-200 thermocycler (MJ Research) ou Mastercycler (Eppendorf). Foi utilizado um total de $25 \mu$ de reação, contendo 2,5 $\mu$ de buffer 10x (Pharmacia), 0,5 $\mu$ de solução contendo dNTPs (2mM), 0,1 $\mu$ le enzima Taq-polimerase (Pharmacia), 1,25 $\mu$ le oligonucleotídeo iniciador forward (10 $\mu \mathrm{M}), 1,25 \mu$ de oligonucleotídeo iniciador reverse $(10 \mu \mathrm{M}), 17,4 \mu \mathrm{l}$ de água milli-Q e $2 \mu l$ de DNA diluído. Foram utilizadas diversas combinações dos oligonucleotídeos iniciadores, listados na tabela 1. Estes oligonucleotídeos foram os mesmos utilizados nas reações de seqüênciamento.

A condição de amplificação utilizada para os genes mitocondriais seguiu um protocolo de touchdown, composto por desnaturação inicial a $95^{\circ} \mathrm{C}$ por 5 minutos, seguido por 10 ciclos de desnaturação a $95^{\circ} \mathrm{C}$ (30s), hibridação dos oligonucleotídeos iniciando em $60^{\circ} \mathrm{C} \mathrm{com}$ diminuição de $1^{\circ} \mathrm{C}$ a cada ciclo (30s), e extensão a $72^{\circ} \mathrm{C}$ (40s). Foram então realizados 30 ciclos de desnaturação a $95^{\circ} \mathrm{C}$ (30s), hibridação dos oligonucleotídeos a $50{ }^{\circ} \mathrm{C}$ (30s), e extensão a $72^{\circ} \mathrm{C}$ (40s). Após o término do total de 40 ciclos houve uma extensão final $a 72^{\circ} \mathrm{C}$ por 10 minutos. Para amplificação de marcadores nucleares, foi utilizada temperatura de hibridação fixa de $50^{\circ} \mathrm{C}$ em 40 ciclos, com tempos e temperaturas de desnaturação inicial, desnaturação e extensão de cada ciclo idênticas ao programa de touchdown descrito acima. 
Tabela 1. Seqüências 5'-3` dos oligonucleotídeos iniciadores utilizados para a amplificação de seqüências mitocondriais e nucleares. Na coluna "Direção", F e R significam forward e reverse, respectivamente.

\begin{tabular}{|c|c|c|c|c|}
\hline Marcador & Oligonucleotídeo & Direção & Sequência 5'-3' & Referência \\
\hline \multirow[t]{15}{*}{ 12S,tRNAVal,16S } & LPHE1248 & $\mathrm{F}$ & AAAGCATGGCACTGAAGAYGCCAAG & E. Tavares, não publicado \\
\hline & 12SL1735 & $\mathrm{F}$ & GGATTAGATACCCCACTATGC & (MIYAKI et al., 1998) \\
\hline & $12 \mathrm{SHC}$ & $R$ & CCGCCAAGTCCTTAGAGTTT & (EBERHARD et al., 2001) \\
\hline & $12 \mathrm{SH} 2181$ & $R$ & GGCTTGTGAGGAGGGTGACGGGC & C. Ribas, não publicado \\
\hline & $12 S L 2169$ & $\mathrm{~F}$ & ACGTACATACCGCCCGTCACCC & AMARAL et al., presente estudo \\
\hline & $16 \mathrm{SH} 2701$ & $R$ & CAGCTATCRCCCAGCTCGGTWGGC & AMARAL et al., presente estudo \\
\hline & 16SH3000ACCIP & $\mathrm{R}$ & ACTCATTTTAGCATTTATTCTCC & AMARAL et al., presente estudo \\
\hline & 16SH3425ACCIP & $R$ & AAGCTCCATAGGGTCTTCTCGTC & AMARAL et al., presente estudo \\
\hline & 16SL2497ACCIP & $\mathrm{F}$ & CCTGTACCGTAAGGGAAAGATG & AMARAL et al., presente estudo \\
\hline & 16SL2908ACCIP & $\mathrm{F}$ & CAGCCTGTAGGCCTTTAAGCAGCC & AMARAL et al., presente estudo \\
\hline & $16 S L 3336$ & $\mathrm{~F}$ & CAATTGTCCCATAAATCGAGACTTG & AMARAL et al., presente estudo \\
\hline & H2294VAL & $R$ & CTTTCAGGTGTAAGCTGARTGC & (AMARAL et al., 2006) \\
\hline & $16 \$ 2-$ & $R$ & ATCCCTGGGGTAGCTTGGTCC & (HARING, 2001) \\
\hline & 16SH3309 & $\mathrm{R}$ & TGCGCTACCTTCGCACGGT & (MIYAKI et al., 1998) \\
\hline & $\mathrm{H} 4017$ & $R$ & GCTAGGGAGAGGATTTGAACCTC & (SORENSON et al., 1999) \\
\hline \multirow[t]{5}{*}{ ATP8/6 } & CO2GQL & $\mathrm{F}$ & GGACAATGCTCAGAAATCTGCGG & (EBERHARD \& BERMINGHAM, 2004) \\
\hline & TLYS9051 & $\mathrm{F}$ & CACCAGCACTAGCCTTTTAAG & (FLEISCHER et al., 2000) \\
\hline & A6PWL & $R$ & CCTGAACCTGACCATGAAC & (EBERHARD \& BERMINGHAM, 2004) \\
\hline & $\mathrm{CO} 3 \mathrm{HMH}$ & $R$ & CATGGGCTGGGGTCRACTATGTG & (EBERHARD \& BERMINGHAM, 2004) \\
\hline & ARG11145 & $\mathrm{R}$ & TTTGTTGAGCCGAAATCAACTGTCT & (AMARAL et al., 2006) \\
\hline \multirow[t]{2}{*}{ ND6 } & TPROFWD & $\mathrm{F}$ & ATCACCAACTCCCAAAGCTGG & (RIESING et al., 2003) \\
\hline & TGLUREV & $R$ & AAGTTTACAACGGCGATTTTTC & (RIESING et al., 2003) \\
\hline \multirow[t]{5}{*}{ CYTB } & ND5L14850Accip & $\mathrm{F}$ & AAACCTACYTAGGAACCTTCGCCC & AMARAL et al., presente estudo \\
\hline & CBL14916Accip & $\mathrm{F}$ & AAACCTACYTAGGAACCTTCGCCC & AMARAL et al., presente estudo \\
\hline & CBL15395Accip & $\mathrm{F}$ & CCMTYGTAGARTGAGCCTGAGGAGG & AMARAL et al., presente estudo \\
\hline & CBH15517Accip & $\mathrm{R}$ & GGTTGTTTGAGCCRGATTCGTG & AMARAL et al., presente estudo \\
\hline & H16065Accip & $R$ & GCCTTCAGTYTTTGGTTTACAAGAC & AMARAL et al., presente estudo \\
\hline \multirow[t]{4}{*}{ ND2 } & ND2L5215 & $\mathrm{F}$ & TATCGGGCCCATACCCCGAAAAT & (HACKETT, 1996) \\
\hline & ND25766H & $\mathrm{R}$ & GGATGARAAGGCTAGRAGTTTTCG & $\begin{array}{l}\text { Modificado de Sorenson et al. } \\
\text { (1999) }\end{array}$ \\
\hline & ND2L5679 & $\mathrm{F}$ & TATCGGGCCCATACCCCGAAAAT & AMARAL et al., presente estudo \\
\hline & H6313TRP & $\mathrm{R}$ & CTCTTATTTAAGGCTTTGAAGGC & (SORENSON et al., 1999) \\
\hline \multirow[t]{4}{*}{ LDH } & $\mathrm{B} 1$ & $\mathrm{~F}$ & CAAACTAAAAGGAGAAATGATGGA & (HELBIG et al., 2005) \\
\hline & NP10 & $\mathrm{R}$ & CACATTCCTCTGAACCAGGTTGAG & (HELBIG et al., 2005) \\
\hline & LDHINTFWDACCIP & $\mathrm{F}$ & TACCTCTGATRTAGAAGAAAT & AMARAL et al., presente estudo \\
\hline & LDHINTREVACCIP & $\mathrm{R}$ & TGTCCTGGYATATCAGYACATGC & AMARAL et al., presente estudo \\
\hline \multirow[t]{5}{*}{ FIB5 } & FIB5 & $\mathrm{F}$ & CGCCATACAGAGTATACTGTGACAT & (MARINI \& HACKETT, 2002) \\
\hline & FIB6 & $\mathrm{R}$ & GCCATCCTGGCGATTCTGAA & (MARINI \& HACKETT, 2002) \\
\hline & FIB5INT2FWD & $\mathrm{F}$ & AAYAAATTGCTGGGGTAGGGTTG & AMARAL et al., presente estudo \\
\hline & FIB5INT1FWD & $\mathrm{F}$ & TTGGTCATCTTYAGTTGCACAG & AMARAL et al., presente estudo \\
\hline & FIB5INTREV & R & GAAAAGCAARACTTGAGGGACTGC & AMARAL et al., presente estudo \\
\hline
\end{tabular}


Ao final de cada reação de PCR, $2 \mu$ l de produto amplificado foram submetidos à separação por eletroforese em gel de agarose 1\%, e um dos poços do gel foi preenchido com marcador de tamanho molecular $1 \mathrm{~Kb}$ plus DNA ladder (Invitrogen). Foram utilizadas nos passos posteriores apenas reações que apresentaram uma única banda de tamanho congruente com o fragmento esperado. Todo o processo de extração e amplificação de amostras de material de museus foi executado em laboratórios onde não se trabalhava com DNA de aves. Reagentes e material de manipulação das amostras foram especialmente comprados para tal fim, como forma de diminuir a possibilidade de contaminação por DNA genômico ou material amplificado exógeno, como proposto por Cooper e Poinar (2000).

A purificação dos produtos de PCR foi realizada com uso de enzimas ou protocolo de polietilenoglicol (PEG). A purificação enzimática consistiu na adição de $1 \mu$ de exonuclease (EXO) e $1 \mu$ de fosfatase alcalina de camarão (SAP) a cada $10 \mu \mathrm{l}$ de produto de PCR, incubação a $37^{\circ} \mathrm{C}$ por 60 minutos, e aquecimento das amostras a $80^{\circ} \mathrm{C}$ por 10 minutos. A purificação dos produtos de PCR por meio do protocolo de PEG foi realizada em microcentrífuga ou centrífuga de placa. Foi adicionado um volume de solução de PEG equivalente ao volume do produto. O material amplificado misturado ao PEG foi incubado por 15 minutos a $37^{\circ} \mathrm{C}$, e posteriormente centrifugado por 30 minutos a 12000 RPM. O sobrenadante foi removido, e então foram adicionados $80 \mu \mathrm{l}$ de etanol 70\%, o que foi seguido por centrifugação por 15 minutos a velocidade de 12.000 RPM. Ao fim da centrifugação o sobrenadante foi novamente descartado, as amostras foram secas a $37^{\circ} \mathrm{C}$, e posteriormente eluídas com $20 \mu$ de Água MilliQ. O material purificado foi seqüenciado utilizando-se o kit Big Dye Terminator v.3.0 (Applied Biosystems), e precipitado de acordo com instruções do fabricante. As amostras foram analisadas nos seqüenciadores automáticos ABI 377 ou ABI 3100 (Applied Biosystems).

Como forma de detectar a amplificação de cópias mitocondriais translocados para o genoma nuclear (numts), todas as amplificações mitocondriais, com exceção do ND6, foram realizadas em múltiplos fragmentos com sobreposição em áreas variáveis de pelo menos 50 pares de 
bases. Dada a menor proporção de cópias de genes nucleares em amostras de penas, músculo e vísceras, quando disponíveis foram utilizadas amostras de sangue do mesmo indivíduo para a amplificação dos marcadores LDH e FIB5. Devido ao avançado grau de deterioração de parte das amostras frescas utilizadas (em sua maioria originárias da Academy of Natural Science of Philadelphia), assim como amostras oriundas de peles taxidermizadas, seqüências de alguns marcadores (predominantemente nucleares) não puderam ser obtidas para algumas amostras. Por outro lado, um pequeno número de indivíduos apresentou alelos de tamanhos distintos nos genes nucleares (sete amostras para o LDH, uma amostra para o FIB5). Em ambos os casos estas seqüências foram codificadas como missing data nas análises filogenéticas.

\subsection{Análises filogenéticas}

As seqüências geradas foram analisadas no programa Codoncode Aligner (Codoncode), e eventuais ambigüidades entre fitas forward e reverse foram corrigidas manualmente. Os eletroferogramas foram cuidadosamente inspecionados para identificação de picos duplos. Espécimes heterozigotos para os marcadores nucleares LDH e FIB5 tiveram tais posições representadas de acordo com o código da IUPAC. O alinhamento das seqüências foi realizado com auxílio do software Clustal X 1.83 (THOMPSON et al., 1997) utilizando-se parâmetros padrão, e todos os hiatos e áreas de alinhamento ambíguo resultantes dos genes ribossômicos e nucleares foram excluídos posteriormente no programa Bioedit 7.0.9 (HALL, 1999). As seqüências codificadoras foram traduzidas com auxílio do programa MEGA 4 (TAMURA ef al., 2007) para verificação de presença de códons de parada, e checagem do padrão de variação das posições dos códons. Todos os marcadores foram testados em relação a desvios significativos de freqüência de bases utilizando o software PAUP 4b10 (SWOFFORD, 2003). Nas inferências filogenéticas os marcadores foram analisados nas seguintes partições: 12S+tRNAVal+16S, ATP8+ATP6, ND6, CYTB, ND2, FIB5 e LDH. Os genes ATP8 e ATP6, assim como o 12S, tRNAVal e 165 foram analisados em partições conjuntas como forma de diminuir o erro estocástico resultante da escolha de modelos de seqüência muito curtas (tRNAVal e ATP8), assim como evitar o 
excesso de parametrização nas análises combinadas. Análises de máxima verossimilhança e análises bayesianas foram realizadas em partições independentes e combinadas. O modelo evolutivo mais adequado para cada partição foi selecionado por meio do critério de informação de Akaike (AIC) utilizando-se o programa MODELTEST v3.7 (POSADA \& CRANDALL, 1998). Como critério de congruência entre as partições, foi avaliada a existência de nós conflitantes entre análises filogenéticas realizadas individualmente com cada uma das partições (assumindo como conflito bootstrap igual ou acima de 70 ou probabilidades posteriores igual ou acima de 0,95). Em casos de incongruência, foram realizadas inferências de máxima verossimilhança com a partição incongruente forçando os arranjos de forma a corroborar o resultado das outras partições. A topologia inicial e a forçada foram então comparadas por meio de teste de Shimodaira-Hasegawa com RELL bootstraping (SHIMODAIRA \& HASEGAWA, 1999) implementado no PAUP, como forma de avaliar se o conflito era significativo. Em caso de ausência de incongruência, as partições foram combinadas.

Análises heurísticas e análises de bootstrap de máxima verossimilhança utilizando 100 réplicas foram realizadas utilizando-se o software Garli v0.951 (ZWICKL, 2006). Devido à limitações do número de modelos disponíveis neste programa, todas as análises evolvendo modelos de seis parâmetros foram realizadas sob o modelo GTR+|+G. Em todas as inferências realizadas no Garli foi utilizada a opção de parada automática das análises, de acordo com parâmetros padrão do programa. Freqüências de bases, parâmetro alfa da distribuição gama e proporção de sítios invariáveis foram estimados durante todas as análises, com exceção das análises com topologias forçadas realizadas para os testes de Shimodaira-Hasegawa. Nestes casos, foram utilizados os mesmos parâmetros obtidos durante a análise do mesmo conjunto sem a topologia forçada. Todas as análises heurísticas foram realizadas duas vezes, como forma de avaliar a convergência das topologias e valores de verossimilhança.

Análises bayesianas foram realizadas utilizando-se o software MrBayes 3.1.2 (RONQUIST \& HUELSENBECK, 2003). De forma similar às análises heurísticas de verossimilhanças, foram realizadas duas análises independentes para 
cada conjunto de dados. Nas análises combinadas foi aplicado a cada partição um modelo evolutivo independente, e os parâmetros de cada uma delas inferidos em separado. Em todas as análises foram utilizados quatro milhões de gerações, com árvores amostradas a cada 100 gerações, e as topologias obtidas nas primeiras 150000 gerações descartadas (período de burnin=1.500). Como forma de avaliar o impacto da dependência de sítios causada pela grande proporção de dados ribossômicos utilizados, foram também realizadas análises bayesianas da partições 12S+†RNAVal+16S, partição mitocondrial combinada e do conjunto de dados total de forma similar à descrita acima, mas neste caso foi utilizando um modelo doublet de 16 parâmetros com acomodação de sítios invariáveis e distribuição gama para as hastes, e o modelo GTR+I+G para as alças. A estrutura secundária dol2s foi implementada de acordo com Espinosa de los Monteros (2003), excluindo-se os sítios não emparelhados em todas as espécies aqui amostradas, além das hastes 8 e 39, que não puderam ser identificadas de forma precisa. O modelo de estrutura secundária utilizado para o tRNAVal (Anexo B) foi inferido utilizando o programa tRNAscan SE (LOWE \& EDDY, 1997). Por fim, o modelo de estrutura secundária utilizado para o $16 \mathrm{~S}$ foi inferido com base em seqüências representativas de todas as ordens de aves atuais (capítulo 3).

\subsection{Estimativas de tempo de divergência}

Foram realizadas estimativas bayesianas de tempo de divergência, que permite variação de taxas de substituição entre diferentes porções da topologia. Foi utilizado o pacote MULTIDISTRIBUTE, que contém os programas ESTBRANCHES E MULTIDIVTIME (THORNE \& KISHINO, 2003). Estas estimativas foram calculadas com base apenas nos dados mitocondriais, dada à ausência de seqüências nucleares para parte das amostras. Apenas um indivíduo foi amostrado por espécie, ou subespécie no caso de espécies não-monofiléticas. Foram realizadas, para cada partição, estimativas de razão de transição/tranversão e freqüência nucleotídicas utilizando o programa PAML 3.41 (YANG, 1997). Estes parâmetros foram então utilizados para a obtenção de tamanhos de ramo e uma matriz de variânciacovariância para cada partição, utilizando o programa ESTBRANCHES. As 
partições foram então analisadas de forma conjunta com o programa MULTIDIVTIME, que por meio de análise bayesiana calcula estimativas de tempo de divergência e intervalos de confiânça de 95\%. Dois conjuntos de dados, um deles incluindo o conjunto mitocondriail completo e outro diferindo pela exclusão de uma das bases de cada par das hastes ribossômicas foram analisados como forma a avaliar o impacto da depedência de sítios nas estimativas de tempo de divergência. As estimativas do MULTIDIVTIME foram realizadas assumindo: período de burnin = 3000; freqüência de amostragem =100; número de amostras =10000; $\mathrm{rttm}=$ 0,555; $r$ ttmsd $=0,185$; brownmean e brownsd $=1,8$; rtrate e rtratesd $=0,31$. Os parâmetros de brownmean, brownsd, rtrate, rtratesd foram calculados de acordo com Pereira et al. (2007). A topologia utilizada nestas análises foi baseada nos resultados do conjunto total, mas com nós sustentados por valores baixos de bootstrap e probabilidades posteriores (menores que 70 e 0,95, respectivamente) colapsados. As análises bayesianas foram em todos os casos repetidas duas vezes, como forma de avaliar a convergência dos resultados entre estimativas distintas do mesmo conjunto de dados.

Três calibrações, sendo duas geológicas e uma fóssil, foram utilizadas. .Apesar da relativa abundância de fósseis conhecidos de acipitrídeos (OLSON, 1985), a carência de estudos osteológicos e análises filogenéticas incluindo linhagens modernas e extintas torna a alocação da maioria dos acipitrídeos fósseis em gêneros atuais um problema complexo (OLSON, 1985; RASMUSSEN et al., 1987), dificultando a utilização deste material em calibrações de relógio molecular. No entanto, a ocorrência de duas espécies de gaviões buteoninos em ilhas vulcânicas (Buteo solitarius e Buteo galapagoensis, Havaí e Galápagos, respectivamente) permite a utilização de idades máximas da divergência destas espécies como pontos de calibração. Nestes casos, assumiu-se que a idade das rochas expostas mais antigas de cada arquipélago é correspondente à idade máxima de cada uma destas espécies. Desta forma, a idade máxima de Buteo galapagoensis assumida foi de 4 milhões de anos com base nas ilhas do leste do arquipélago de Galápagos (WHITE; MCBIRNEY; DUNCAN, 1993), enquanto para Buteo solitarius a idade máxima assumida foi de 5,1 milhões de anos, de acordo com as datações de K-Ar das rochas mais antigas de Kavai (FLEISCHER, R. C.; 
MCINTOSH, 2001). O terceiro ponto de calibração foi baseada no espécime mais antigo atribuído à família Pandionidae (HARRISON \& WALKER, 1976). Com base neste fóssil, foram incorporadas sequências de Pandion haliaeetus (GENBANK DQ780884) na análise, e determinado o limite mínimo de divergência entre Pandionidae e os gaviões buteoninos como 37 milhões de anos, como sugerido por Ericson et al. (2006). Devido à remoção da seqüência mais externa pelo MULTIDIVTIME durante a análise, foram também adiconadas seqüências do genoma mitocondrial de Falco peregrinus disponíveis no Genbank (AF 090338). As seqüências de Falco peregrinus e Pandion haliaetus apresentaram inserções de códons no ND6, o que tornou o alinhamento difícil devido à alta divergência em relação às seqüências do grup interno. Por este motivo, 21 bases (correspondentes aos códons 107-113 em Pandion) foram eliminadas do alinhamento do ND6.

\subsection{Reconstrução do comportamento migratório}

Como forma de avaliar aspectos gerais sobre a evolução do comportamento migratório entre os gaviões buteoninos, foi realizada uma otimização deste caráter na topologia resultante das análises combinadas, utilizando máxima parcimônia no programa Mesquite v. 2.01 (MADDISON \& MADDISON, 2007). Nós com suporte abaixo de 0,95 nas análises bayesianas e 70 de bootstrap de verossomilhança foram colapsados. Utilizando codificação multi-estado, as espécies foram classificadas como a) sedentárias ou migrantes irregulares, b) migrantes parciais e c) migrantes completos, de acordo com dados da literatura (THIOLLAY, 1994; FERGUSONLEES \& CHRISTIE, 2001; BILDSTEIN, 2004; BILDSTEIN \& ZALLES, 2005). Embora a maioria dos dados acerca do comportamento migratório das espécies seja congruente entre as fontes supracitadas, em alguns casos foram encontradas informações contraditórias. Desta forma, a seguir foram justificadas as codificações nestes casos: 1) Buteo albicaudatus: dados recentes apontam possíveis movimentos migratórios na Bolívia (OLIVO, 2003); entretanto estes dados têm sido tomados com cautela devido à presença destas aves em área de migração de Buteo swainsoni, o que pode gerar confusão quanto a identificação dos indivíduos (BILDSTEIN, 2004). Na 
ausência de informações independentes corroborando este padrão, a espécie foi considerada não-migratória; 2) Buteo albigula: embora FergussonLees e Christie (2001) não considerem a espécie como migrante latitudinal, dados recentes (PAVEZ, 2000) sugerem movimentos sazonais em larga escala no Chile, e por este motivo a espécie foi classificada como migrante parcial, como em Bildstein (2004); 3) No caso de Buteo rufofuscos e Geranoaetus melanoleucus não foi possível encontrar evidência concreta de movimentos sazonais de larga escala, e ao contrário de Bildstein (2004), consideramos estas espécies sedentárias; 4) Espécies do gênero Harpagus são consideradas presumidamente sedentárias (THIOLLAY, 1994; FERGUSON-LEES \& CHRISTIE, 2001) ou migrantes irregulares ou locais (BILDSTEIN, 2004); embora existam indícios de movimentação no sudeste do Brasil (CABANNE \& SEIPKE, 2005), informações sobre a sazonalidade e extensão destes processo são ainda desconhecidas; na ausência de dados mais concretos optou-se por codificar estas espécies como não-migratórias. Apesar dos acipitrídeos realizarem migrações altitudinais e longitudinais (BILDSTEIN \& ZALLES, 2005), dados sobre este tipo de comportamento são escassos, e apenas migrações latitudinais foram consideradas na análise. Embora sejam reconhecidos os benefícios da análise de comportamento migratório utilizando informações em níveis taxonômicos mais baixos possíveis (KONDO \& OMLAND, 2007), dada a escassez de informações disponíveis para muitas subespécies a análise foi restringida a uma amostragem em um nível predominantemente específico. 


\section{Resultados}

\subsection{Características das seqüências}

As partições alinhadas contendo hiatos totalizaram 7.308 pb, e após a exclusão de hiatos e áreas de alinhamento ambíguo das seqüências ribossômicas e nucleares incluíram 7.000 pb. O alinhamento das seqüências ribossômicas apresentou 2.689 pares de base (12S, 987 pb; tRNAVal, 72 pb;16S, $1630 \mathrm{pb}$ ), e deste total foram utilizados 2.467pb após a remoção dos hiatos. De acordo com os modelos de estrutura secundária utilizados, deste total 1.022pb (correspondentes a 511 pares de sítios) foram incluídos em hastes ribossômicas. O alinhamento dos marcadores nucleares totalizou 507 pb para ○ FIB5, e 581 pb para $\circ$ LDH, e a exclusão dos hiatos levou à utilização de alinhamentos de 483 pb e 571 pb, respectivamente. Dos 7.000 pb da matriz final, 6.429 pb foram utilizados em análises combinadas, devido aa conflito de um dos marcadores nucleares em relações às outras partições. Os modelos evolutivos selecionado para todas as partições mitocondriais, assim como conjuntos combinados, apresentaram seis parâmetros com proporção de sítios invariáveis e distribuição gama, enquanto para ambos os genes nucleares foi selecionado um modelo de dois parâmetros (HKY) sem proporção de sítios invariáveis, e taxas de evolução iguais para todos os sítios. Características das seqüências, assim como detalhes dos modelos evolutivos utilizados, foram sumarizados na Tabela 2. 


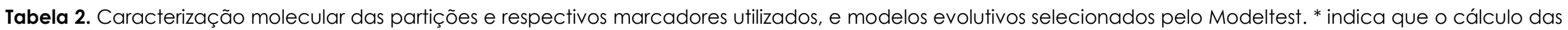

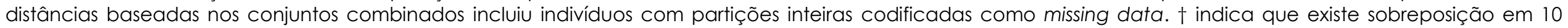
pares de base utilizados entre ATP8 e ATP6, que foram utilizados apenas uma vez nas partições combinadas.

\begin{tabular}{|c|c|c|c|c|c|c|c|c|c|}
\hline Partição & $\begin{array}{c}\text { Sítios } \\
\text { utilizados } \\
\text { por } \\
\text { partição }\end{array}$ & Modelo selecionado & $\begin{array}{c}\text { Proporção } \\
\text { de sítios } \\
\text { invariáveis }\end{array}$ & $\begin{array}{c}\text { Parâmetro } \\
\text { alfa }\end{array}$ & Marcador & $\begin{array}{c}\text { Sítios } \\
\text { utilizados } \\
\text { por gene }\end{array}$ & $\begin{array}{c}\text { Sítios } \\
\text { variáveis }\end{array}$ & $\begin{array}{c}\text { Sítios } \\
\text { informativos } \\
\text { para } \\
\text { parcimônia }\end{array}$ & $\begin{array}{c}\text { Intervalo de } \\
\text { divergência } \\
\text { não-corrigida }\end{array}$ \\
\hline \multirow[t]{3}{*}{ 12S+tRNAVal+16S } & 2467 & GTR+I+G (hastes+alças) & 0,578 & 0,700 & $12 S$ & 924 & 248 & 215 & $0,000-0,090$ \\
\hline & & GTR+I+G (apenas alças) & 0,471 & 0,813 & tRNAVal & 62 & 13 & 9 & $0,000-0,129$ \\
\hline & & & & & $16 S$ & 1481 & 395 & 340 & $0,000-0,096$ \\
\hline \multirow[t]{2}{*}{ ATP8+ATP6 } & $842^{\dagger}$ & $T R N+I+G$ & 0,469 & 1,191 & ATP8 & 168 & 97 & 87 & $0,000-0,244$ \\
\hline & & & & & ATP6 & 684 & 289 & 257 & $0,000-0,145$ \\
\hline ND2 & 1041 & $G T R+1+G$ & 0,455 & 1,238 & ND2 & 1041 & 477 & 426 & $0,000-0,151$ \\
\hline ND6 & 519 & $T V M+1+G$ & 0,475 & 1,272 & ND6 & 519 & 233 & 217 & $0,000-0,173$ \\
\hline CYTB & 1077 & $G T R+1+G$ & 0,589 & 1,942 & CYTB & 1077 & 404 & 366 & $0,000-0,118$ \\
\hline FIB5 & 483 & HKY & - & - & FIB5 & 483 & 66 & 44 & $0,000-0,054$ \\
\hline $\mathrm{LDH}$ & 571 & HKY & - & - & $\mathrm{LDH}$ & 571 & 69 & 38 & $0,000-0,027$ \\
\hline mtDNA total & $5946^{\dagger}$ & $T V M+1+G$ & 0,532 & 0,927 & $\begin{array}{l}\text { Mitocondriais } \\
\text { combinados }\end{array}$ & 5946 & 2154 & 1916 & $0,000-0,182 *$ \\
\hline mtDNA total +FIB5 & $6429^{\dagger}$ & $T V M+1+G$ & 0,537 & 0,832 & $\begin{array}{l}\text { Mitocondriais } \\
\text { e FIB5 } \\
\text { combinados }\end{array}$ & 6429 & 2220 & 1960 & $0,000-0,184^{*}$ \\
\hline
\end{tabular}


Nenhum códon de parada inesperado foi encontrado nas seqüências codificadoras, e a maior parte da variação destes genes esteve concentrada na terceira posição do códon. De forma similar, não foi detectado desvio significativo de composição de bases em nenhum marcador ou partição (p>0.05). A autenticidade das seqüências mitocondriais aqui utilizadas é suportada por: 1) utilização predominante de amostras ricas em DNA mitocondrial; 2) seqüências idênticas nas regiões de sobreposição entre fragmentos distintos; 3) seqüências facilmente alinháveis com dados de outras espécies de aves disponíveis no Genbank; 4) regiões codificadoras que não apresentaram códons de parada não-esperados; e 5) árvores mitocondriais gene-específicas congruentes entre si.

Foi encontrada evidência de saturação em todos os genes codificadores mitocondriais, dado o acúmulo não linear de substituições com o aumento da distância genética, predominantemente na terceira posição de códon (Anexo C).

\subsection{Análises filogenéticas}

As análises realizadas entre partições mitocondriais independentes geraram topologias relativamente mal resolvidas, entretanto completamente congruentes entre si em relação a nós bem sustentados (Anexos D a J). Por este motivo estes dados foram combinados em um único conjunto (Figura 1). As análises baseadas no conjunto mitocondrial combinado apresentaram a maioria dos nós bem sustentados por valores de bootstrap de verossimilhança, e probabilidades posteriores bayesianas acima de 70 e 0,95 respectivamente. Os resultados destas análises não suportam o monofiletismo de Buteo, Leucopternis e Buteogallus, e cinco clados principais foram obtidos. Três clados são basais ao restante de todos os gaviões buteoninos, e incluem 1) espécies do gênero Harpagus; 2) Espécies do gênero Ictinia e 3) Rostrhamus, Geranospiza e Busarellus. O restante das espécies foi agrupado em dois clados principais, formados por 4) Leucopternis plumbeus, basal a um clado contendo Harpyhaliaetus, Leucopternis lacernulatus, Leucopternis schistaceus e espécies do gênero Buteogallus, e 5) uma linhagem mais derivada de gaviões buteoninos, contendo espécies do gênero Buteo, Geranoaetus e Parabuteo, além do restante das espécies de Leucopternis. Na porção mais derivada da topologia, existe uma linhagem formada 
apenas por representantes do gênero Buteo do Velho Mundo (B. rufofuscos, B. augur, B. auguralis, B. rufinus, B. buteo vulpinus, B. buteo buteo, B. hemilasius, B. japonicus e B. refectus). Duas espécies, Buteo jamaicensis e Leucopternis albicollis, não se mostram monofiéticas, havendo mistura de haplótipos com táxons proximamente relacionados.

A análise bayesiana da partição 12S+tRNAVal+16S utilizando dados de estrutura secundária gerou uma topologia praticamente idêntica à oriunda da análise que não utilizou esta informação, variando predominantemente em relação a nós mal resolvidos em ambas os casos, e variações pequenas nas probabilidades posteriores (Anexos E e F).

As inferências baseadas nos dados nucleares, por outro lado, de modo geral apresentaram-se pouco resolvidas e, embora com estrutura geral similar à topologia mitocondrial, indicaram nós conflitantes bem sustentados. A topologia do FIB5 (figura 2), apesar da baixa resolução, é altamente congruente com a topologia dos dados mitocondriais, diferindo com alto suporte nodal apenas em relação ao posicionamento de Leucopternis lacernulatus em um clado composto por L. schistaceus, Buteogallus anthracinus e Buteogallus aequinoctialis, ao contrário do relacionamento irmão de L. lacernularus e B. meridionalis, como sugerido pela topologia mitocondrial. No entanto, uma topologia oriunda de busca heurística de máxima verossimilhança com o FIB5 forçando o relacionamento obtido com os genes mitocondriais não diferiu significativamente da árvore não forçada, de acordo com um teste de Shimodaira-Hasegawa $(P=0,081)$. Por este motivo, a partição do FIB5 foi combinada ao conjunto mitocondrial. Já a análise do LDH (figura 3) mostrou diversas relações incongruentes em relação ao conjunto mitocondrial, como 1) inclusão de alelos do complexo Leucopternis albicollis/ L. occidentalis em clados distintos, sendo um deles exclusivo destas espécies, e outro contendo alelos de Geranoaetus, Buteo polyosoma e Buteo albicaudatus e 2) agrupamento irmão de Buteo albigula a Buteo albonotatus em um clado externo à linhagem dos Buteo mais derivados (limitada em B. platypterus). 


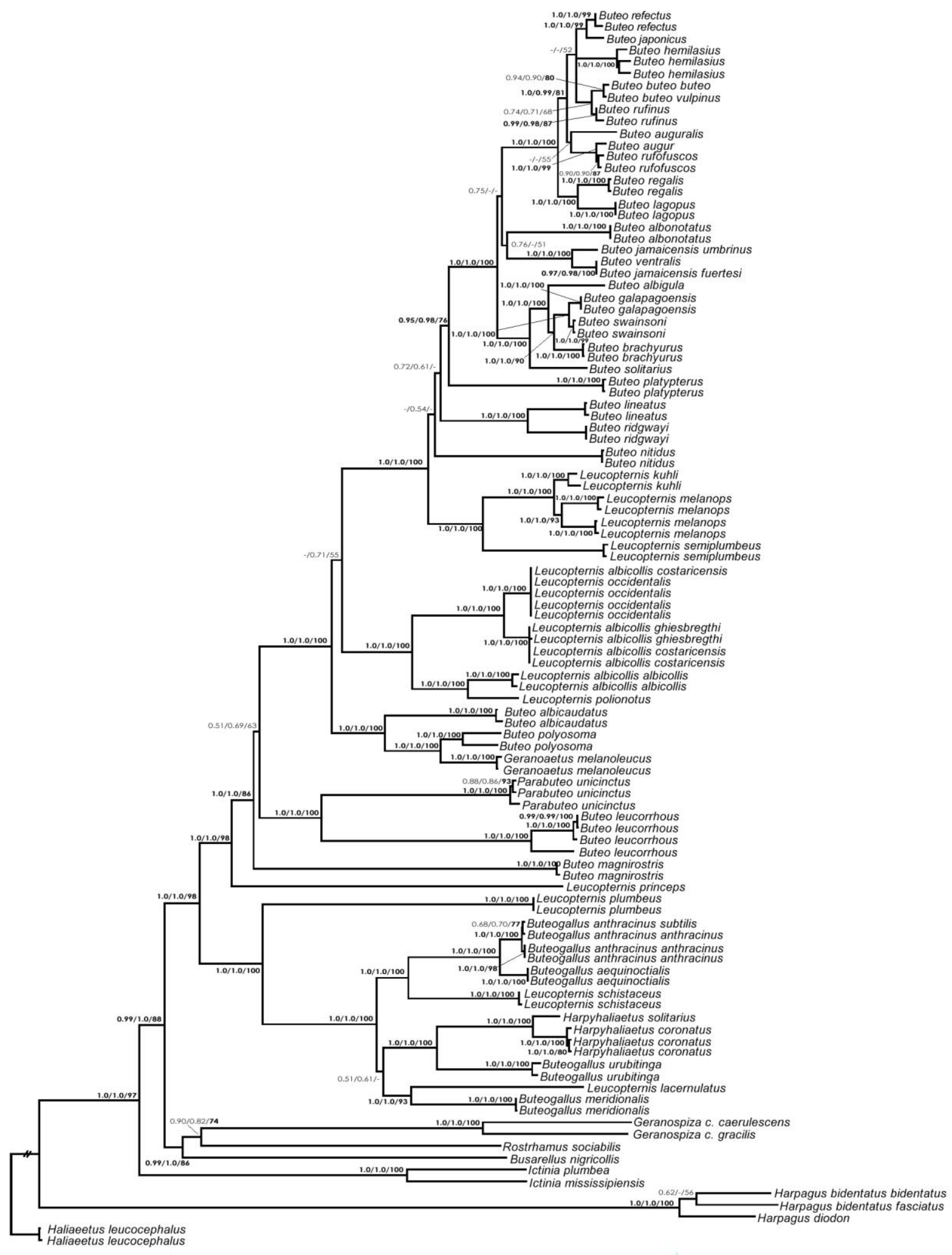

0.1 substituiçōes/sitio

Figura 1. Topologia de máxima verossimilhança inferida a partir dos dados mitocondriais combinados (- In 42655.2362). Números próximos aos nós indicam probabilidades posteriores sem e com utilização de modelo de estrutura secundária, e bootstrap de máxima verossimilhança, respectivamente. Números em negrito representam valores de bootstrap iguais ou maiores que 70 e probabilidades posteriores iguais ou maiores que 0,95 . 
Neste caso, uma topologia forçada de forma a apresentar as relações obtidas com os dados mitocondriais foi significativamente diferente da árvore original $(P<0,001)$, e por este motivo esta partição não foi incluída na análise total.

A topologia baseada no conjunto total (marcadores mitocondriais+FIB5, Figura 4) foi idêntica à inferência baseada nos dados mitocondriais combinados, diferindo apenas no aumento da sustentação de alguns ramos (e.g. nó levando ao clado de B. platypterus + B. ridgwayi). De forma similiar ao encontrado com a partição do 12S+tRNAVal+16S, a maior diferença entre topologias bayesianas inferidas sem e com dados de estrutura secundária com base nos conjuntos mitocondrial combinado e total se deu em nós com baixa resolução em ambas análises, além de pequenas variações no valor de probabilidade posteriores (Figuras 1 e 4). 


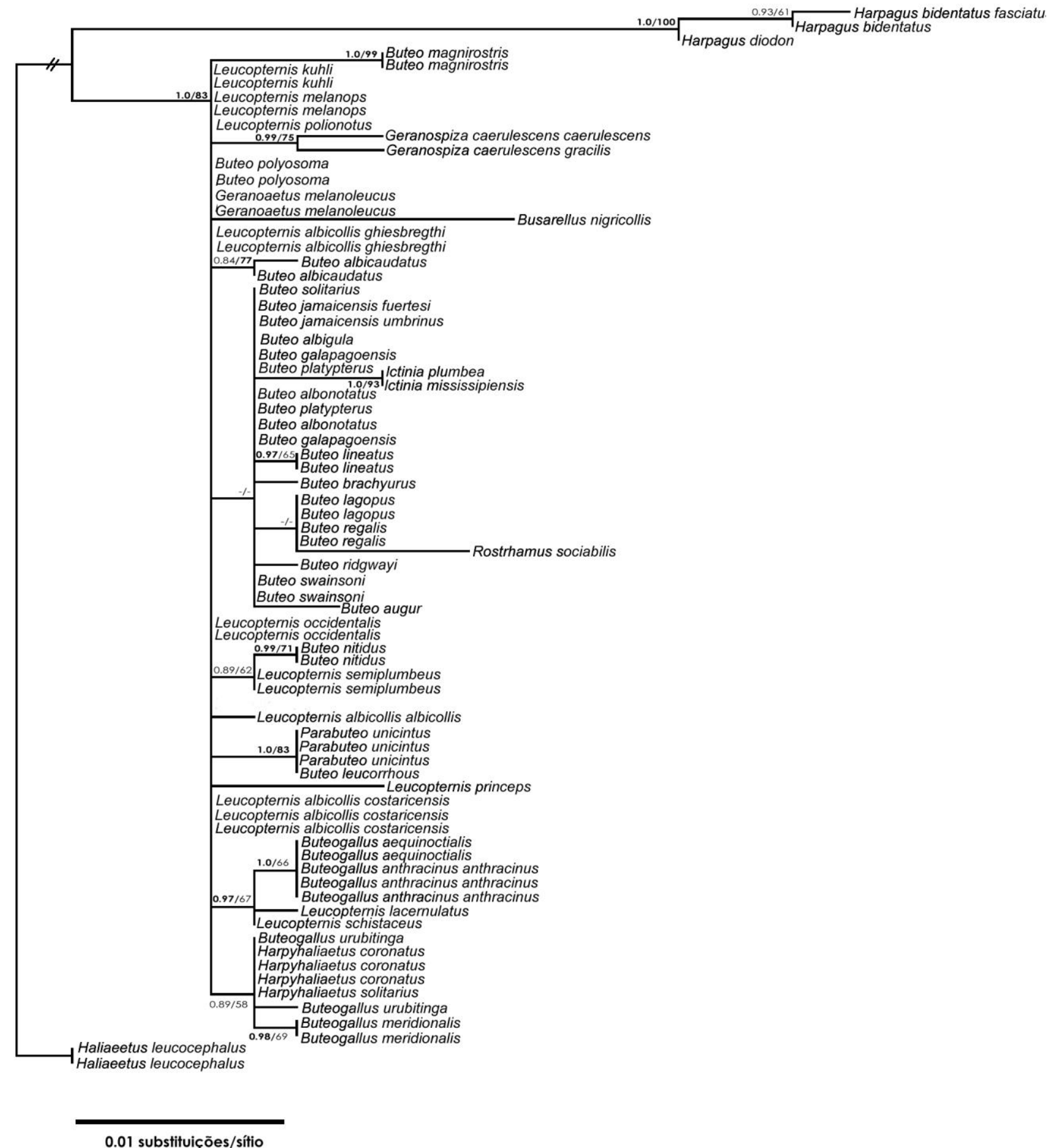

0.01 substituições/sítio

Figura 2. Topologia de máxima verossimilhança inferida a partir do FIB5 (-In 1157.5542). Números próximos aos nós indicam probabilidades posteriores e valores de bootstrap, respectivamente. Números em negrito representam valores de bootstrap iguais ou maiores que 70 e probabilidades posteriores iguais ou maiores que 0,95 


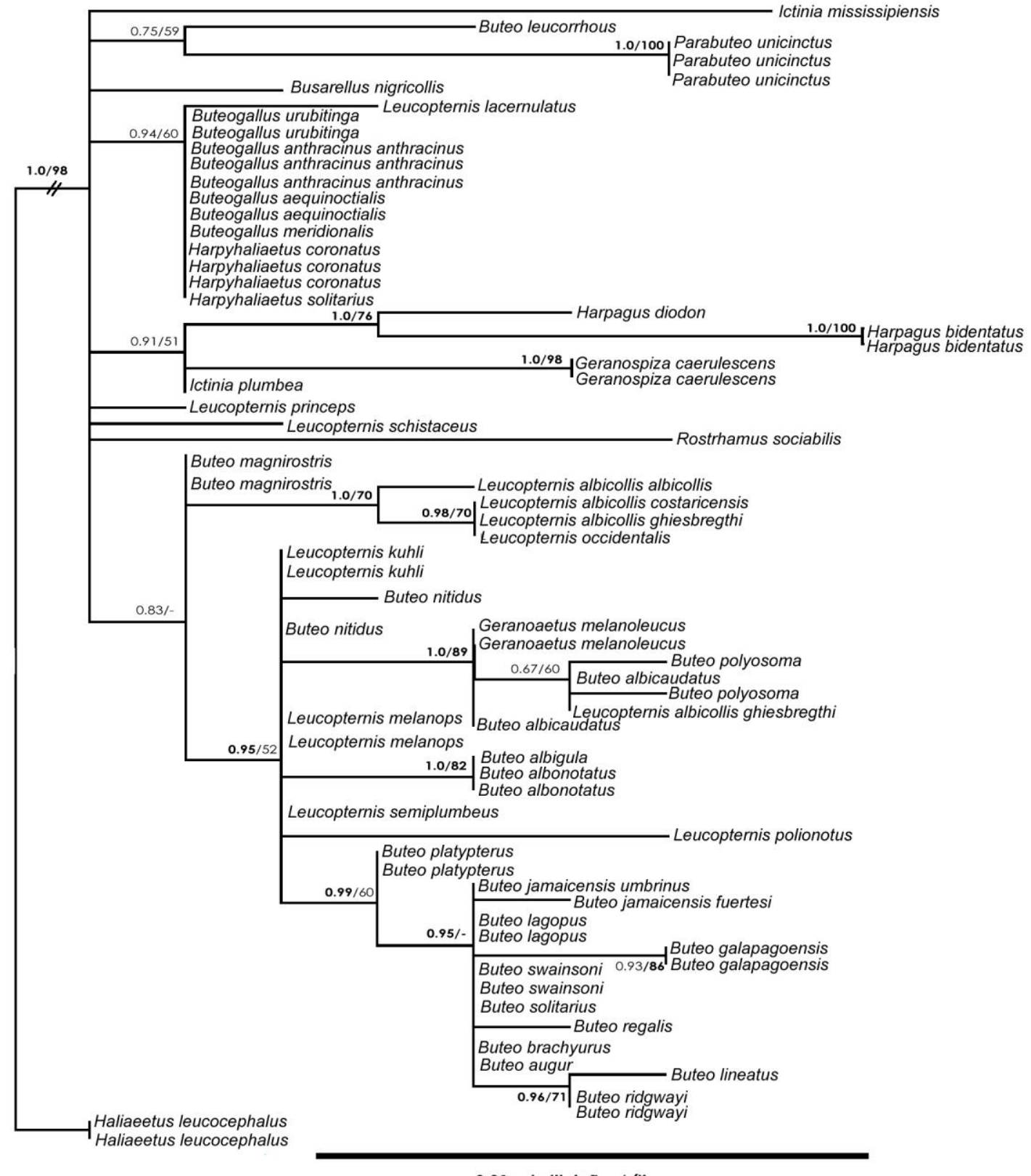

0,01 substituiçōes/sítio

Figura 3. Topologia de máxima verossimilhança inferida a partir do LDH (-In 1302.4443). Números próximos aos nós indicam probabilidades posteriores e valores de bootstrap, respectivamente. Números em negrito representam valores de bootstrap iguais ou maiores que 70 e probabilidade posterior iguais ou maiores que 0,95 . 


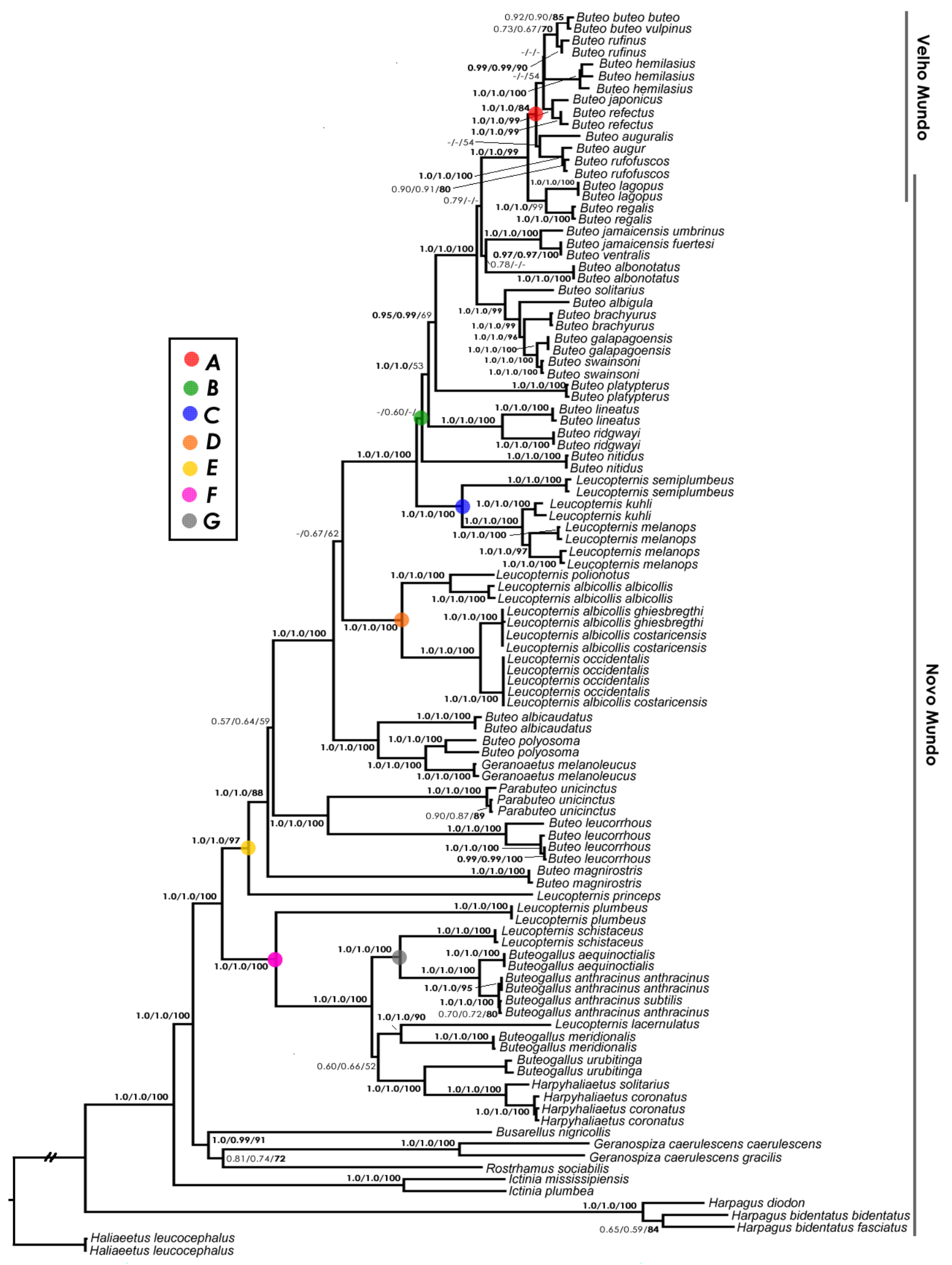

0.1 substituições/sítio

Figura 4. Topologia de máxima verossimilhança inferida a partir dos dados mitocondriais e do FIB5 combinados (In -44086.4130). Números próximos aos nós indicam probabilidades posteriores sem e com utilização de modelo de estrutura secundária e bootstrap de máxima verossimilhança, respectivamente. Nós indicados pelas letras A a $G$ foram utilizados como referência na discussão. A sobreposição das barras em Buteo lagopus representa a ocorrência deste táxon tanto no Novo Mundo como no Velho Mundo. 


\subsection{Estimativas de tempo de divergência}

As inferências de tempo de divergência baseadas nos conjuntos contendo hastes completas e parciais sugerem resultados muito similares, tanto nas datas inferidas, como nos intervalos de confiança de 95\% (Anexos $\mathrm{K}$ e L). Por este motivo, foram utilizadas na discussão as inferências baseadas no conjunto contendo hastes completas (figura 5). Estas estimativas apontaram um período de diversificação do grupo que pode ter iniciado desde o fim do Oligoceno (considerando espécies de Harpagus como gaviões buteoninos) ou no Mioceno (limitando o grupo em Ictinia), e que se estendeu até o Pleistoceno e Holoceno.

Ainda com base nestas análises, a separação entre os gaviões buteoninos + Haliaeetus leucocephalus de Pandion (assim representando a separação Accipitridae/ Pandionidae) foi estimada entre 41,5 e 95,6 milhões de anos atrás. A representação deste nó foi omitida da figura 5 para proporcionar melhor clareza das outras relações, dado o longo tamanho de ramo levando a Pandion (mas veja Anexos K e L). 


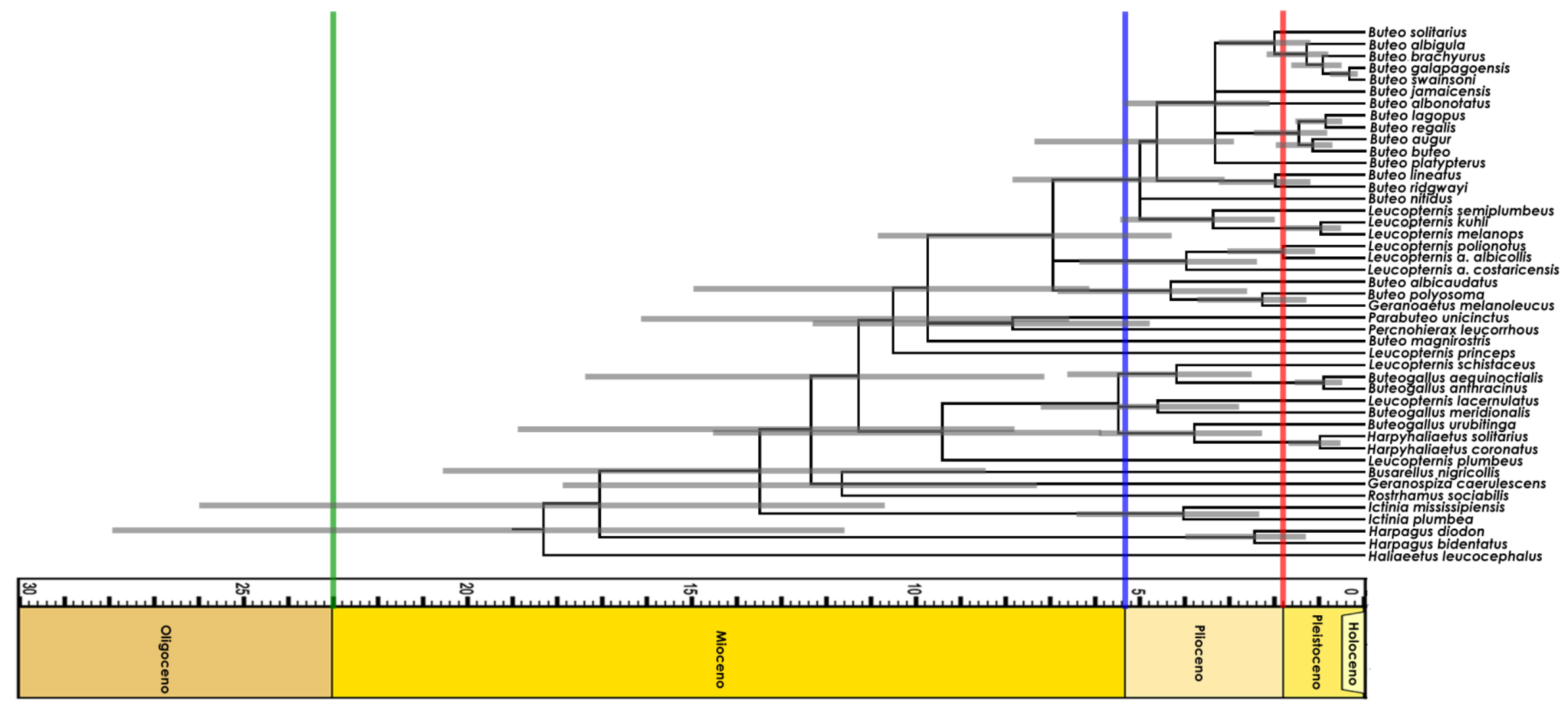

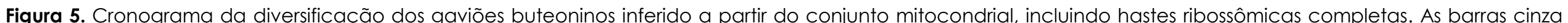
representam intervalos de confiança de $95 \%$. Pandion foi eliminado para melhor ilustração do período de diversificação do grupo interno. 


\subsection{Reconstrução do comportamento migratório}

A reconstrução mais parcimoniosa do comportamento migratório recuperou 18 passos, apontando transições de estado ancestral sedentário para migrante parcial, de ancestral migrante parcial para migrante completo, e de ancestral migrante parcial para sedentário. Alguns estados ancestrais não puderam ser resolvidos, como no caso dos pares lctinia plumbea e I. mississipiensis e B. galapagoensis e B. swainsoni, além do ramo que leva à porção mais derivada da árvore. Pelo menos sete surgimentos independentes do comportamento migratório ocorreram durante a evolução do grupo (Figura 6). 


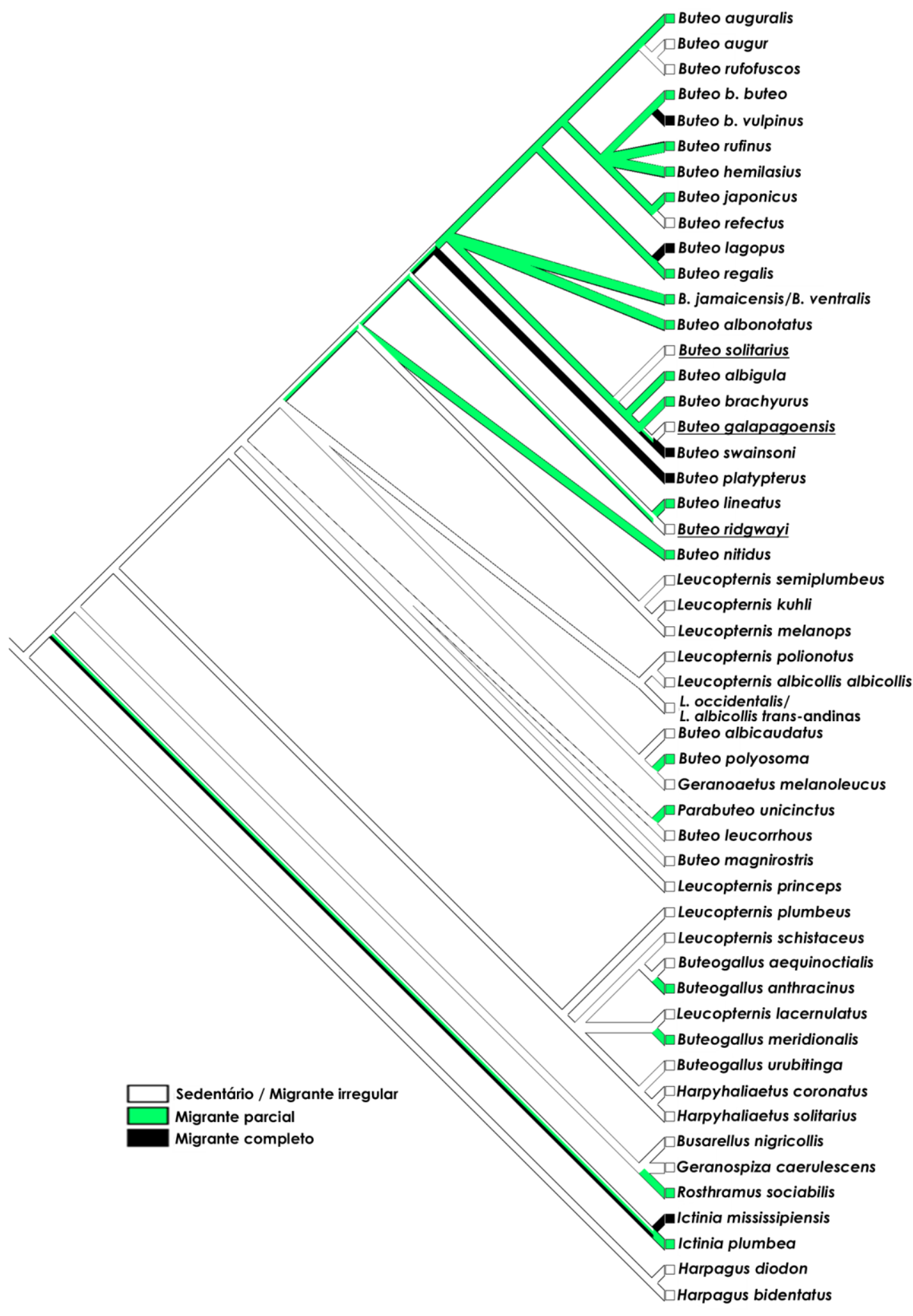

Figura 6. Reconstrução de máxima parcimônia do comportamento migratório utilizando a topologia inferida a partir dos dados combinados. Foram reconstruídos 18 passos. Espécies insulares apresentam-se grifadas. Ramos contendo mais de uma cor representam reconstruções ancestrais não resolvidas. 


\section{Discussão}

\subsection{Relações filogenéticas e efeitos da inclusão de informações de estrutura secundária}

As inferências filogenéticas baseadas nos dados combinados (mtDNA+FIB5) apontam a falta de correspondência entre a classificação tradicional de gêneros de gaviões buteoninos e clados monofiléticos. Com amostragem ampliada de táxons e marcadores, são aqui corroborados resultados anteriores que indicam a falta de monofiletismo de Buteo (RIESING et al., 2003), assim como Leucopternis e Buteogallus (AMARAL et al., 2006; LERNER et al., no prelo).

Apesar da falta de consenso da maior parte das relações inferidas em relação à taxonomia tradicional, alguns agrupamentos isolados foram já sugeridos por autores clássicos. O relacionamento próximo entre Buteogallus urubitinga e espécies de Harpyhaliaetus, por exemplo, foi postulado por Amadon (AMADON, 1949) e Amadon e Eckelberry (AMADON \& ECKELBERRY, 1955), e a retenção do primeiro em Buteogallus foi apenas justificada com base na diferença de tamanho em relação as espécies de Harpyhaliaetus. Por outro lado Ridgway (1876) propôs que Leucopternis schistaceus e Leucopternis plumbeus seriam membros típicos de Buteogallus. $\bigcirc$ agrupamento de Leucopternis polionotus, Leucopternis albicollis e Leucopternis occidentalis é recorrente em diversas revisões taxonômicas (e.g. HELLMAYR \& CONOVER, 1949; AMADON, 1964; AMADON \& BULL, 1988; THIOLLAY, 1994; FERGUSON-LEES \& CHRISTIE, 2001), assim como o relacionamento irmão entre Leucopternis melanops e Leucopternis kuhli (AMADON, 1964; STRESEMANN \& AMADON, 1979; HAFFER, 1987; THIOLLAY, 1994; FERGUSON-LEES \& CHRISTIE, 2001).

Em relação a trabalhos moleculares prévios incluindo gaviões buteoninos (FLEISCHER \& MCINTOSH, 2001; RIESING et al., 2003; AMARAL et al., 2006; LERNER et al., no prelo), a maioria das relações propostas entre grupos de espécies recentemente derivadas são aqui corroboradas ou definidas com maior resolução. No entanto, em contraste com estudos anteriores, a presente análise incluiu uma grande proporção de seqüências de evolução lenta, além de seqüências mitocondriais de evolução mais rápida. Desta 
forma, a combinação de marcadores de taxas distintas permitiu a resolução não somente das especiações recentes com alto suporte estatístico, mas também pela primeira vez a maioria dos nós na base da árvore que ligam linhagens principais de gaviões buteoninos. Entre os exemplos de nós profundos inferidos com alto suporte estatístico estão, por exemplo: a base do clado E (Figura 4), com o representante mais basal sendo Leucopternis princeps; posicionamento do clado de R. sociabilis, B. nigricollis e G. caerulescens em relação a outras espécies de gaviões buteoninos; e agrupamento de espécies de Harpagus, gênero não incluído em análises filogenéticas anteriores, basal à todas as espécies de gaviões buteoninos. Desta forma, a alta resolução da topologia como um todo abre a possibilidade de testes de hipóteses sobre a diversificação da linhagem em todos os níveis de divergência utilizando, por exemplo, otimização de caracteres e estimativas de tempos de divergência, além de permitir a reorganização nomenclatural do grupo de forma mais segura (para propostas de mudanças de nomenclatura, veja final do capítulo).

Os resultados aqui apresentados reforçam o agrupamento de Buteogallus meridionalis como irmão de Leucopternis lacernulatus, como encontrado em Amaral et al. (2006), que é distinto ao encontrado por Lerner, Klaver e Mindell (no prelo), que sugerem que L. lacernulatus seria irmão do clado de B. urubitinga/Harpyhaliaetus, com B. meridionalis basal a todas estas espécies. Este representa o único caso de conflito entre os dois trabalhos, e pode ser reflexo de diferenças entre número de táxons e marcadores amostrados.

As relações entre espécies da porção mais derivada da topologia, contendo principalmente espécies do gênero Buteo (clado A, Figura 4), é menos resolvida do que o restante da topologia. Este padrão pode ser resultado da maior proporção de táxons contendo missing data no presente conjunto de dados, ou ainda reflexo de um processo de diversificação rápida neste clado. Por outro lado, algumas relações não foram bem definidas por nenhum trabalho até o momento, incluindo o presente, e um número ainda maior de marcadores pode ser necessário para a resolução destas relações. Entre os exemplos é possível citar a falta de resolução no posicionamento de Buteo nitidus, as relações internas no clado contendo 
Rosthramus, Geranospiza e Busarellus, e os dois nós resolvidos com baixo suporte entre os nós B e E (Figura 4).

O posicionamento basal de Harpagus aos gaviões buteoninos com base na amostragem aqui utilizada indica que o gênero não pertence a linhagens aninhadas no grupo. Por outro lado, isto não necessariamente significa que esta é a linhagem irmã de todos os outros buteoninos, já que o relacionamento deste gênero nunca foi testado em um contexto mais amplo na família. Análises incluindo representantes de outras linhagens de acipitrídeos serão necessárias para confirmar o relacionamento irmão deste gênero ao restante do grupo.

Algumas relações inferidas levantam aspectos interessantes sobre limites específicos de táxons de história controversa. Utilizando a distância $P$ no ND2 como parâmetro, a divergência entre uma amostra de Buteogallus anthracinus subtilis é nula se comparada a de um dos indivíduos de $B$. anthracinus anthracinus, e menor que 0,1\% quando comparada a outras duas amostras de B. a. anthracinus. Embora com baixa resolução, as análises sugerem que B. a. anthracinus pode ser parafilético em relação à Buteogallus a. subtilis. Estes dados corroboram a falta de diagnosticabilidade de $B$. anthracinus subtilis encontrada por Clark (2007) com base em dados de plumagem, e ressalta a necessidade de um estudo genético de ampla amostragem, incluindo também o táxon endêmico de Cuba B. a. gundlachi (não amostrado em nenhum estudo genético até o presente). Já em relação a Buteo ventralis, foi observada maior proximidade do único indivíduo amostrado a um indivíduo de Buteo jamaicensis do Novo México (EUA) correspondente a sub-espécie Buteo j. fuertesi, e basal a este par um indivíduo de Buteo jamaicensis umbrinus, oriundo das Bahamas. Estes resultados indicam o parafiletismo de Buteo jamaicensis em relação a Buteo ventralis, padrão similar ao encontrado por Riesing et al. (2003). Embora a proximidade entre $B$. jamaicensis e $B$. ventralis seja amplamente sugerida na literatura (e. g. FERGUSON-LEES \& CHRISTIE, 2001), os resultados sugerem que uma análise mais aprofundada neste complexo será de interesse para a reavaliação de $B$. ventrais, assim como na inferência da história evolutiva deste complexo. Apesar do relacionamento próximo entre $L$. polionotus/L.albicollis/L.occidentalis inferido aqui ter sido amplamente 
sugerido na literatura clássica, dois aspectos importante emergem nas análises combinadas: mistura de haplótipos mitocondriais entre $L$. occidentalis e subespécies trans-andinas de L. albicollis, e maior proximidade entre L. a. albicollis a L. polionotus do que a outras subespécies, corroborando Lerner, Klaver e Mindell (no prelo). As subespécies trans-andinas de Leucopternis albicollis apresentam uma variação clinal da quantidade de negro na plumagem, praticamente ausente nos táxons mais ao norte (L. a. ghiesbregthi), e atingindo maior quantidade de negro no táxon mais ao sul (L. a. costaricensis) (FERGUSON-LEES \& CHRISTIE, 2001). É possível que haja fluxo gênico extensivo entre os táxons trans-andinos do complexo L. albicollis/ L. occidentalis, ou estes táxons representem unidades evolutivas recentes, e a mistura de haplótipos possa ser resultado de presença de polimorfismos ancestrais. Um estudo com amostragem mais ampla dos táxons transandinos, e dados nucleares de evolução rápida (e.g. microsatélites), será necessário para determinar se este padrão é resultado de diversificação recente ou fluxo gênico entre estes táxons.

Enquanto a utilização de mais de um indivíduo na maioria das espécies apontou mistura de haplótipos mitocondriais para alguns táxons, por outro lado também revelou alta divergência mitocondrial intra-específica de algumas espécies, se comparadas ao padrão geral do grupo. Entre os casos mais claros de haplótipos divergentes, utilizando distância não corrigida do ND2 (veja também tamanho de ramos, figuras 1 e 4) é possível citar: Geranospiza caerulescens, 5,7\%, indivíduos oriundos do Perú e Nordeste do Brasil, correspondendo às subespécies G. c. caerulescens e G. c. gracilis, respectivamente; Leucopternis melanops, 1,4\% (comparável a aproximadamente 1,5\% entre L. melanops e L. kuhli, corroborando Lerner, Klaver e Mindell, no prelo), seqüências oriundas de indivíduos do Perú e da Guiana agrupando em dois filogrupos distintos; Harpagus bidentatus, 3,4\% (comparável a aproximadamente 3,5\% entre amostras de $\mathrm{H}$. diodon e $\mathrm{H}$. bidentatus), indivíduos do Panamá e Brasil Central, correspondendo às subespécies H. b. fasciatus e H. b. bidentatus; Buteo polyosoma, 1,4\%, ambas as amostras do Peru; e finalmente, Buteo leucorrhous, (seqüências de ND2 não puderam ser obtida para uma das amostras, divergência $P$ em ATP6 de 1,9\%), um indivíduo do sul do Brasil e indivíduos andinos (padrão também 
encontrado em RIESING et al., 2003). Estes padrões podem ser conseqüência de estruturação genética presente ou passada, ou mesmo indicar a existência de diversidade morfológica críptica. Estudos filogeográficos e de taxonomia alfa serão de especial interesse nestes casos, e podem trazer informações importantes para reavaliação de limites específicos, identificação de diversidade críptica e entendimento de processo evolutivos envolvidos na especiação de acipitrídeos neotropicais. Uma revisão taxonômica de Buteo leucorrhous utilizando dados genéticos e morfológicos incluindo espécimes da maior parte da distribuição conhecida do táxon, revelou a existência de dois filogrupos divergentes (i. e. 7\% de divergência na região Pseudo-controladora mitocondrial, comparado, por exemplo, com a distância de $5 \%$ entre as espécies Buteo regalis e Buteo lagopus), que apresentam uma área de contato nas porções mais próximas entre os biomas onde estão distribuídas, florestas andinas e Mata Atlântica, em Tucumán, noroeoste da Argentina (Amaral et. al. em preparação).

A inclusão de modelos de estrutura secundária, apesar da grande quantidade de sítios correlacionados (511 pares de sítios), não gerou diferenças significativas entre topologias inferidas tanto na partição do 12S/tRNAVal/16S como nos conjuntos combinados, assim como estimativas de tempo de divergência. Dada a baixa variação das hastes, é possível que o efeito da correlação de sítios seja mínimo neste nível de divergência. Este fato, no entanto, não elimina a possibilidade de efeitos negativos significativos da correlação de sítios de divergência mais elevados. Desta forma, advoga-se a inclusão de informação de estrutura secundária caso seqüências de DNA de marcadores ribossômicos sejam utilizadas em inferências de níveis taxonômicos mais elevados na família.

\subsection{Conflito entre seqüências nucleares e mitocondriais}

Embora o sinal filogenético dos marcadores mitocondriais e do nuclear FIB5 tenha sido semelhante, houve conflito significativo do LDH em relação ao restante do conjunto de dados; este conflito se deu tanto em relação ao posicionamento de algumas espécies (e.g. Buteo albigula, Buteo albonotatus) quanto à mistura de alelos de Leucopternis albicollis ghiesbregthi e do complexo B. albicaudatus/B. polyosoma/G. melanoleucus. 
De acordo com a filogenia mitocondrial, no entanto, estes dois grupos de espécies pertencem a clados reciprocamente monofiléticos. Embora a congruência entre genes mitocondriais aqui encontrada seja esperada, já que estes são herdados em uma única unidade de ligação, análises de marcadores que apresentam modos de herança distintos (e.g. mitocondriais e nucleares) constituem estimativas independentes de árvores de genes, que não necessariamente correspondem à árvore das espécies. Esta incongruência pode ser explicada por: 1) retenção de polimorfismos ancestrais no marcador nuclear ou 2) extensiva hibridização entre espécies de gaviões buteoninos na natureza.

De acordo com a teoria da evolução neutra, em situações de ausência de evolução reticulada (i.e. hibridização), a probabilidade de um marcador coalescer é inversamente proporcional ao tamanho populacional efetivo (MOORE, 1995). A forma de herança quase exclusivamente materna (veja rara exceção em aves em KVIST et al. 2003) é responsável pelo tempo de coalescência quatro vezes menor em marcadores mitocondriais em relação a marcadores nucleares autossômicos. Conseqüentemente, árvores de marcadores mitocondriais possuem uma probabilidade substancialmente maior de resolver entrenós curtos de forma precisa que marcadores nucleares (MOORE, 1995). Estudos de simulação sugerem que em casos quando um entrenó é suficiente longo para permitir a probabilidade de 0,95 da inferência correta pelo DNA mitocondrial, a probabilidade deste mesmo nó ser inferido corretamente com um único marcador nuclear autossômico é de apenas 0,62. Estes mesmos estudos sugerem, dessa forma, que 16 topologias oriundas de marcadores nucleares independentes seriam necessárias para a obtenção da co,nfiança obtida pela árvore de haplótipos mitocondriais (MOORE, 1995).

Por outro lado a existência de hibridização presente ou passada entre espécies pode levar a padrões similares aos encontrados pela retenção de polimorfismos ancestrais. Até o presente, embora escassos, existem registros bem documentados de hibridização entre gaviões buteoninos na América no Norte. Um macho híbrido entre Buteo swainsoni e Buteo lagopus foi recentemente identificado por meio de caracteres morfológicos e genéticos (CLARK \& WITT, 2006). Em outro caso similar, dois indivíduos com fenótipo e 
alelos nucleares de Buteo swainsoni apresentaram haplótipos mitocondriais de Buteo jamaicensis (HULL et al., 2007). Embora o monofiletismo mitocondrial dos complexos L. albicollis/L. polionotus/Loccidentalis (apesar da mistura de haplótipos mitocondriais entre subespécies de L. albicollis e L. occidentalis) e Buteo albicaudatus/B. polyosoma/G. melanoleucus possam ser utilizados como argumento contra a existência de cruzamento entre espécies destes clados na natureza, este padrão não necessariamente refuta a presença de hibridização. As fêmeas de aves representam o sexo heterogamético, e portanto, estão sujeitas à regra de Haldane (HALDANE, 1922), que postula a menor viabilidade de híbridos do sexo heterogamético. A observação da proporção significativa de machos em espécimes híbridos de aves é conhecido há quase um século (GUYER, 1909), antes mesmo da formulação desta hipótese. Desta forma, a predição da regra de Haldane aliada à forma de herança materna pode ter impacto significativo no padrão da topologia mitocondrial, ao ocultar mistura de haplótipos oriundos de hibridização. Dada a baixa taxa de sobrevivência, e portanto reprodução, de fêmeas híbridas, este processo por ser responsável por um padrão monofilético artefatual, que não necessariamente refuta a existência de hibridização.

Apesar da descrição de casos esporádicos de hibridização na natureza citados acima, as análises aqui apresentadas podem indicar um indício inicial de retenção de polimorfismos ancestrais como o fator predominante na geração destes padrões pois: a) todos os casos de incongruência do LDH, inclusive a mistura de alelos entre espécies de clados distintos, ocorrem em linhagens que possuem entrenós ancestrais curtos ou mal resolvidos pelos dados mitocondriais (Figura 1 e 4); b) espécies de acipitrídeos apresentam tempo de geração longo se comparado à aves passeriformes, por exemplo, - que pode tornar mais lenta a coalescência de genes nucleares autossômicos; c) espécies como B. albonotatus, G. melanoleucus, B. albicaudatus e sub-espécies trans-andinas de L. albicollis são táxons amplamente distribuídas e relativamente comuns, o que pode indicar grande tamanho populacional; este processo pode ser responsável por uma diminuição no efeito da deriva genética, assim aumentando o tempo necessário para a aquisição de monofiletismo recíproco; d) Apesar da extensiva simpatria em alguns casos, espécies dos clados Leucopternis 
albicollis/L. polionotus e B.albicaudatus/B. polyosoma/G. melanoleucus ocupam habitats radicalmente distintos (florestas/áreas abertas, respectivamente), o que diminui a chance potencial de hibridização e que até o presente não foi descrita entre componentes destes clados. A avaliação da congruência de topologias oriundas de múltiplos genes nucleares, utilizando amostragem substancial de indivíduos para cada táxon, representa a estratégia mais adequada para avaliação entre estas duas hipóteses alternativas, e os processos envolvidos devem ser explorados em detalhe em estudos posteriores. Fenômenos de reticulação podem trazer impacto significativo na formulação do cenário evolutivo das espécies em questão, e devem fazer parte da narrativa sobre a diversificação de um grupo (MOORE, 1995).

Na ausência de dados nucleares adicionais, consideramos a filogenia inferida a partir do conjunto mtDNA+FIB5 como a hipótese mais provável para o relacionamento das espécies grupo, dada a concordância do sinal filogenéticos entre genes oriundos de unidades de herança independentes, coalescência mais rápida de marcadores mitocondriais e possível retenção de polimorfismos ancestrais no LDH.

\subsection{Biogeografia histórica e evolução do comportamento migratório}

\subsubsection{Padrões de diversificação de uma linhagem de distribuição quase global}

Os resultados aqui apresentados sugerem que a diversificação dos gaviões buteoninos é antiga, podendo ter iniciado no Oligoceno (considerando Harpagus como o membro mais basal do grupo) ou Mioceno (limitando o grupo em Ictinia), e se estendido até o Pleistoceno e Holoceno. Enquanto a região Neotropical reúne linhagens antigas e recentes, por outro lado um clado contendo espécies exclusivas do Velho Mundo (figura 4, clado do nó A) surgiu apenas em algum ponto entre o Plioceno superior e o Pleistoceno, e representa a porção mais derivada de uma linhagem que contém espécies neotropicais e neárticas, surgida entre o fim do Mioceno e o Plioceno após a radiação neotropical (figura 4., clado do nó B). A possível origem de espécies neárticas e do Velho Mundo de gaviões buteoninos a partir de ancestrais neotropicais é amplamente discutida na literatura 
(VOOUS \& DE VRIES, 1978; AMADON, 1982; RIESING et al., 2003; AMARAL et al., 2006), e corroborada pelas inferências aqui apresentadas.

A existência de espécies predominantemente neárticas e do Velho Mundo na porção mais derivada da topologia é espacial e temporalmente congruente com processos que afetaram a comunicações entre ambientes terrestres. O fechamento do Istmo do Panamá é resultado de um longo processo geológico, que iniciou há 15 milhões de anos atrás e culminou na ligação completa entre a América Central e a América do Sul durante o Plioceno (entre 3.1 e 2.8 milhões de anos atrás, COATES \& OBANDO, 1996). Este período é congruente com o surgimento da linhagem representada pelo clado interno ao nó B (Figura 4), delimitado por B. platypterus. Já mais recentemente flutuações do nível do mar durante o fim do Terciário e no Quartenário afetaram a ligação de terra entre o Velho e o Novo Mundo por meio da exposição e submersão periódica da Beríngia, após 100 milhões de ligação de terra contínua (HOPKINS, 1973; MARINCOVICH JR \& GLADENKOV, 1999; 2001). Assim, é possível que uma espécie ancestral que originou a linhagem do nó A tenha colonizado a região Paleártica a partir da região Neártica, e esta periodicidade da conexão tenha então isolado uma linhagem ancestral na Ásia, a partir da qual se iniciou a diversificação por quase todo o Velho Mundo. Uma hipótese alternativa, e também temporalmente congruente com os resultados seria a formação de extensos glaciares separando populações no Velho e Novo Mundo de uma espécie ancestral, que posteriormente teria dado origem à linhagem do Velho Mundo (RIESING et al., 2003). O padrão de diversificação no Velho Mundo a partir de linhagens predominantemente neotropicais foi também observado entre espécies das famílias Caprimulgidae (BARROWCLOUGH et al., 2006) e Falconidae (GRIFFITHS et al., 2004), e estimativas de tempo de divergência entre espécies pertencentes às últimas duas famílias podem ser úteis na identificação de eventos vicariantes operando na diversificação destas três linhagens.

Embora as espécies predominantemente norte-americanas tenham surgido, de acordo com as estimativas aqui apresentadas, apenas após o fim do Mioceno, e a diversificação da linhagem do Velho Mundo date da transição do Plioceno para o Pleistoceno, diversos fósseis atribuídos ao 
gênero Buteo foram encontrados em depósitos de períodos anteriores do Terciário da América do Norte e da Europa. Entre estes exemplos encontramse, por exemplo: Buteo grangeri, Oligoceno Superior, EUA (WETMORE \& CASE, 1934); Buteo pusillus, Mioceno Médio, França (BALLMAN, 1969) e Buteo spassovi, Mioceno Superior, Bulgária (BOEV \& KOVACEV, 1998). Esta incongruência pode estar relacionada a três fatores principais: 1) erro na estimativa de tempo de divergência; 2) extinção de linhagens antigas, pertencentes ou semelhantes osteologicamente aos gaviões buteoninos atuais; 3) alocação inadequada do registro fóssil. Embora a inferência de tempos de divergência seja um dos pontos mais controversos do uso de dados moleculares em estudos evolutivos (veja revisão em ARBOGAST et al., 2002), e extinções de linhagens de gaviões buteoninos provavelmente tenham ocorrido durante a evolução do grupo, a alocação de espécies fósseis em gêneros atuais é um problema reconhecidamente complexo (RASMUSSEN et al., 1987). A atribuição de espécies fósseis ao gênero Buteo está longe de ser definitiva (OLSON, 1985), e estudos anatômicos detalhados, além de análises cladísticas incluindo espécies extintas e atuais de acipitrídeos ainda não estão disponíveis. Um panorama das relações entre gêneros de acipitrídeos tem emergido apenas recentemente, e estes resultados apontam para a dificuldade de alocação até mesmo de espécies atuais em nível genérico, dado o polifiletismo de diversos gêneros como atualmente aceitos (RIESING et al., 2003; HELBIG et al., 2005; LERNER \& MINDELL, 2005; AMARAL et al., 2006; GRIFFITHS et al., 2007). A alocação de espécies fósseis em gêneros atuais realizada sem o uso de métodos cladísticos pode resultar em gêneros parafiléticos ou polifiléticos, já que a similaridade entre material osteológico normalmente fragmentário (como no caso dos holótipos das espécies supracitadas) e esqueletos de espécies atuais pode não apenas representar sinapomorfias, mas também retenção de caracteres ancestrais (plesiomorfias) e homoplasias. Desta forma, estudos filogenéticos incluindo dados osteológicos de espécies fósseis e atuais de gaviões buteoninos serão essenciais para uma avaliação crítica da alocação de espécies extintas incluídas atualmente no gênero Buteo, e comparação entre a idade de fósseis em um contexto filogenéticos e as estimativas de tempo de divergência aqui obtidas. 
A origem geográfica do ancestral do grupo dos gaviões buteoninos como um todo permanece desconhecida. Lerner, Klaver e Mindell (no prelo) encontraram uma relação irmã do gênero Butastur a todos os outros gaviões buteoninos, mas não incluíram Harpagus, enquanto o oposto ocorreu no presente trabalho. Desta forma, a avaliação das relações entre Harpagus (exclusivamente neotropical) e Butastur (composto por espécies africanas e indo-malaias), aparentemente basais aos gaviões Buteoninos, será útil para o entendimento dos eventos de dispersão ou vicariâcia que originaram o provável ancestral neotropical no qual coalesce o restante da linhagem.

\subsubsection{A evolução do comportamento migratório: conseqüências para o processo de diversificação}

A reconstrução do comportamento migratório indicou múltiplos ganhos e perdas deste estado entre gaviões buteoninos, o que tem se mostrado de forma recorrente com outros grupos de aves. Resultados similares foram encontrados, por exemplo, entre espécies dos gêneros de Passeriformes Muscisaxicola (CHESSER, 2000), Catharus (OUTLAW et al., 2003) e Icterus (KONDO \& OMLAND, 2007), além de populações do complexo Myiarchus swainsoni (JOSEPH et al., 2003).

Um dos mecanismos tidos como responsáveis por esta plasticidade é a possível "supressão" e "ativação" da capacidade de migração, que possivelmente pode ter existido já nos ancestrais das aves (ZINK, 2002). Por envolver características complexas ligadas, é pouco provável que a maquinaria biológica necessária para a execução de movimentos sazonais tenha sido obtida de forma tão lábil, como a maioria das reconstruções tem sugerido. Desta forma, ganhos e perdas representariam "ativações" (ou modificações, no caso de transições de migrante parcial para migrante completo) e "supressões" do comportamento, respectivamente.

A utilização de um caráter multi-estado na reconstrução teve como efeito a maximização da quantidade de informações na presente análise, e indicou diversas transições entre os estados sedentário, migrante parcial e migrante completo. O número de transições, no entanto, seria muito menor 
se um caráter binário ausência/presença de migração fosse utilizado, o que suporta o uso deste tipo de caráter (KONDO \& OMLAND, 2007). Desta forma, foram inferidas relações irmãs dos tipos sedentário/sedentário, sedentário/migrante parcial, migrante parcial/migrante completo, e em um único caso de migrante completo/sedentário (Buteo swainsoni e Buteo galapagoensis).

Com exceção dos casos onde a reconstrução da condição ancestral é ambígua, a evolução de migrantes completos aparentemente se deu a partir de ancestrais migrantes parciais. Por outro lado, a maioria dos migrantes parciais é derivada de ancestrais sedentários. Desta forma, de modo geral a reconstrução corrobora a hipótese de Cox (1985), que sugere a transição gradual da condição sedentária para migrante parcial, e deste para migrante completo.

Apesar dos múltiplos ganhos ao longo da topologia, a reconstrução ressalta a existência de um clado composto por espécies predominantemente migratórias do gênero Buteo. Este clado contrasta com o mapeamento do restante da topologia, pelo fato do comportamento ter se originado poucas vezes, ou até mesmo uma única vez. Devido à topologia conservadora utilizada na análise, que incluiu apenas nós definidos com valores altos de bootstrap ou probabilidades posteriores, não foi possível estabelecer a condição ancestral do clado do nó B. Este fato é conseqüência do posicionamento ambíguo de B. nitidus na topologia, que quando analisado como o táxon mais basal no clado compreendido pelo nó B (como indicado na análise heurística de máxima verossimilhança), leva a reconstrução a indicar um único surgimento do comportamento neste clado (Anexo M). Mesmo com a falta de resolução da reconstrução na base deste clado, a análise sugere apenas uma origem do comportamento migratório na porção mais derivada desta linhagem (clado do nó $B$ exceto $B$. nitidus, $B$. platypterus, B. ridgwayi e B. lineatus) a partir de um ancestral migrante parcial. Desta forma, ao contrário do restante da topologia, a porção mais derivada corrobora o surgimento único do comportamento migratório em linhagens selecionadas de aves, como observado, por exemplo, no caso do gênero Piranga (BURNS, 1998). 
A evolução do comportamento migratório completo já foi postulada como uma resposta a condições ambientais em mudança, ocorrendo mais provavelmente a partir de um ancestral migrante parcial (BERTHOLD, 1999). Uma outra teoria relacionada a evolução da migração, postulada por Chesser (2000), sugere que muitas espécies que se reproduzem na região Neártica e migram para a região Neotropical pertenceriam a gêneros predominantemente migratórios, e representariam linhagens neárticas derivadas de um ancestral migratório. Ambas as hipóteses são congruentes com o padrão da linhagem migratória de Buteo. Sob esta ótica, a colonização ou permanência de espécies do gênero Buteo em áreas temperadas da América do Norte, após o fechamento do Istmo do Panamá, e posteriormente do Velho Mundo, via Estreito de Bering, pode ter sido iniciado a partir da região Neotropical apenas por meio de um ou poucos ganhos do comportamento migratório. Este processo pode ter ocorrido como resposta a flutuações climáticas durante o Plioceno, época de tendência mundial de aridez (ROSSETI et al., 2005), e incluída no intervalo de confiança das datações deste clado. Desta forma, o ganho do comportamento migratório pode ter funcionado como uma "inovação chave" (Winker 2000), permitindo a exploração destes novos territórios, mesmo sob condições extremas de ambientes temperados durante períodos glaciais, por meio de movimentos sazonais para latitudes mais baixas. Assim, a evolução do comportamento migratório no gênero Buteo pode ter contribuído indiretamente para a diversificação desta linhagem de gaviões buteoninos ao permitir a expansão da distribuição da linhagem em ambientes antes não ocupados pelo grupo.

A ativação e supressão do comportamento migratório podem ter afetado a diversificação dos gaviões buteoninos, no entanto, não apenas de forma indireta, mas como mecanismo direto de especiação. A observação da relação do número de espécies migratórias de uma determinada região e o grau de endemismo do grupo em áreas insulares e continentais levou Bildstein (2004) a postular a teoria denominada migration dosis. De acordo com esta teoria, todos os anos grupos de migrantes se desviam de suas rotas principais devido a fatores diversos, como o efeito do vento na perturbação de rotas migratórias (THORUP et al., 2003). Como diversas espécies de aves 
migram em bandos, grupos inteiros de indivíduos poderiam ser deslocados para áreas distantes da rota principal, o que poderia ocasionar a morte, o retorno à área de reprodução, ou a especiação; esta última ocorreria por meio da colonização da nova área, reprodução, e perda da capacidade de migração (BILDSTEIN, 2004; BILDSTEIN \& ZALLES, 2005). Estes novos territórios, continentais ou insulares, poderiam apresentar nichos vazios devido à ausência de competidores, fator que pode ser importante durante o processo de perda do comportamento migratório (OUTLAW et al., 2003). O migration dosis poderia estar relacionado, por exemplo, à diversificação de espécies pertencentes a grupos de aves de rapina migratórias em todo o Mundo, como representantes dos gêneros Falco, Accipiter e Buteo (BILDSTEIN \& ZALLES, 2005). Espécies de gaviões buteoninos poderiam estar especialmente sujeitas a este mecanismo, pois migram predominantemente por meio de vôo planado proporcionado por térmicas geradas pelo aquecimento diferencial do solo, processo pouco eficiente sobre grandes corpos d'água (BILDSTEIN \& ZALLES, 2005), o que dificultaria o retorno ao continente. Com base em inferências filogenéticas anteriores de menor resolução (FLEISCHER \& MCINTOSH, 2001; RIESING et al., 2003), Bildstein (2004) postulou que este processo poderia ter sido responsável pela especiação de B. galapagoensis, e possivelmente, B. solitarius, endemismos insulares que seriam proximamente relacionados às espécies altamente migratórias $B$. swainsoni e B. brachyurus; ainda de acordo com este autor, o mesmo pode ter ocorrido com o também insular B. ridgwayi, possivelmente relacionado aos migratórios B. platypterus ou B. lineatus. Os resultados obtidos aqui são congruentes com as premissas da hipótese de migration dosis por indicar, com alta sustentação: 1) o relacionamento irmão de $B$. galapagoensis e $B$. swainsoni, com inclusão de B. solitarius, B. albigula e B. brachyurus neste último clado, e 2) o relacionamento irmão de B. ridgwayi a B. lineatus. Outro ponto que suporta esta hipótese é especiação do par B. swainsoni/B. galapagoensis ter ocorrido há menos de um milhão de anos atrás, indicando a rapidez da supressão do comportamento, umas das premissas do migration dosis. Desta forma, a evolução e supressão do comportamento migratório podem ter levado a especiação de pelo menos três espécies insulares de gaviões buteoninos (Buteo galapagoensis, B. ridgwayi e B. solitarius). 
A reconstrução de caracteres de evolução rápida, como o comportamento migratório, é beneficiada não apenas pela codificação multi-estado, mas também pela inclusão de dados em níveis taxonômicos mais baixos possíveis, incluindo subespécies e populações que apresentem estados distintos do resto das espécies as quais pertencem (JOSEPH et al., 2003; KONDO \& OMLAND, 2007). Entretanto, no caso dos gaviões buteoninos existe escassez de dados sólidos sobre movimentos sazonais já em nível específico, o que não permite este grau de refinamento. Uma avaliação mais minuciosa dos processos aqui discutidos será possível apenas com obtenção de informações adicionais de movimentos migratórios de todas as espécies e subespécies do grupo (especialmente neotropicais).

\subsubsection{Padrões e processo de diversificação na região Neotropical}

\subsubsection{Disjunções cis- e trans-andinas: padrão temporal de diversificação}

As inferências filogenéticas sugerem disjunções independentes entre espécies e linhagens cis e trans-andinas (ou seja, distribuídas a leste e oeste dos Andes, respectivamente), corroborando com amostragem ampliada relações propostas anteriormente (AMARAL et al., 2006; LERNER et al., no prelo). Duas disjunções completas entre grupos de espécies florestais puderam ser identificadas: entre Leucopternis semiplumbeus e o complexo melanops/kuhli (Figura 4, nó C, e figura 7), e entre táxons trans e cis-andinos do complexo L. albicollis/L. polionotus/L. occidentalis (figura 4, nó D, e figura 8). Duas outras espécies florestais (Leucopternis princeps e Leucopternis plumbeus) são exclusivamente trans-Andinas, mas são basais a clados ecologicamente diversos que contém espécies distribuídas a leste dos Andes, ou nos dois lados da cordilheira (figura 4, nós $E$ e $F$, respectivamente), provavelmente oriundas de um ancestral cis-Andino. Apesar dos largos intervalos de confiança obtidos nas estimativas do tempo de divergência, existe grande sobreposição de datas de divergência entre os nós $C$ e $D$, assim como entre os nós E e F (Figuras 4 e 5). 


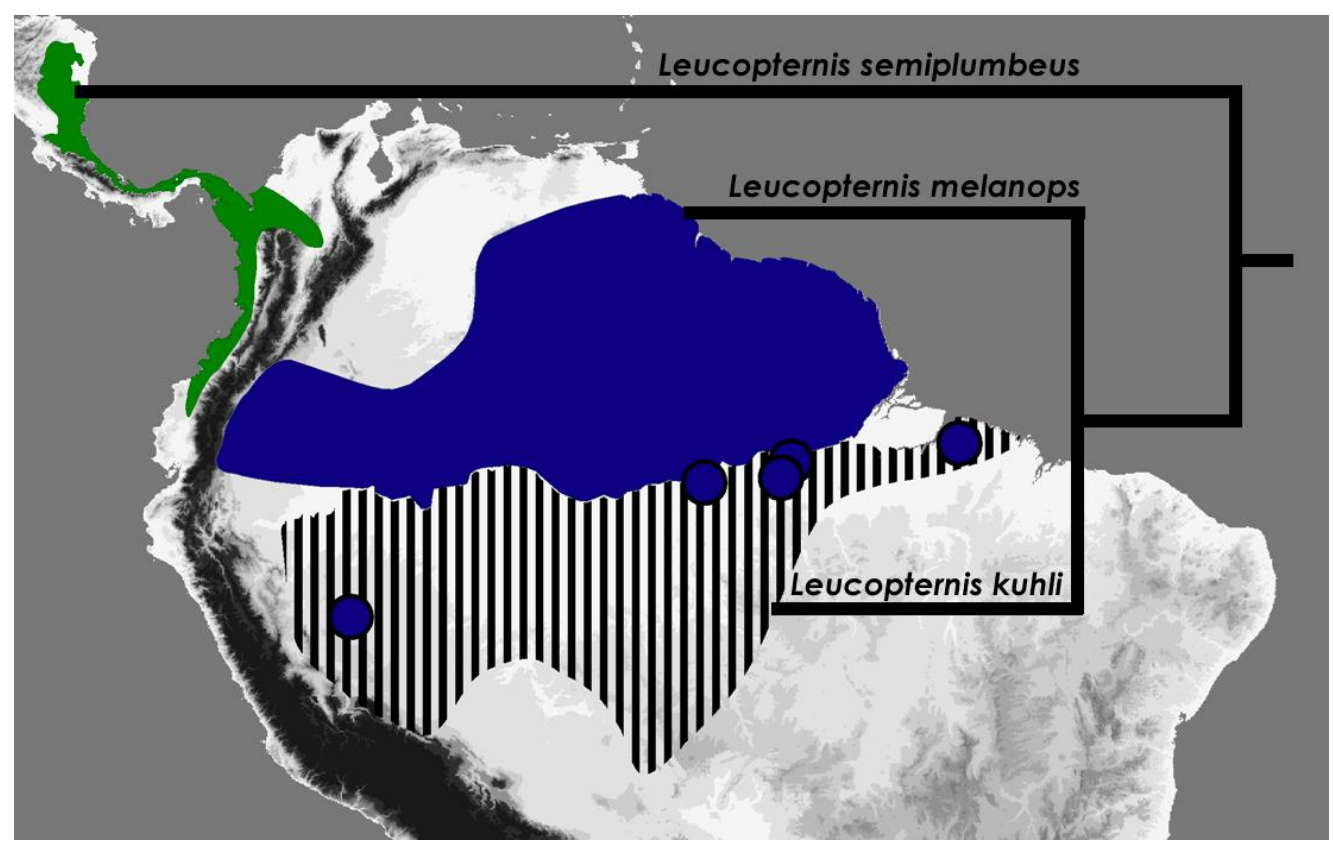

Figura 7. Mapa de distribuição e relações de L. semiplumbeus, L. melanops e L. kuhli. As distribuições utilizadas são oriundas da base de dados Infonatura (2007). As localidades de $L$. melanops ao sul do Amazonas estão de acordo com Amaral et al. (2007).

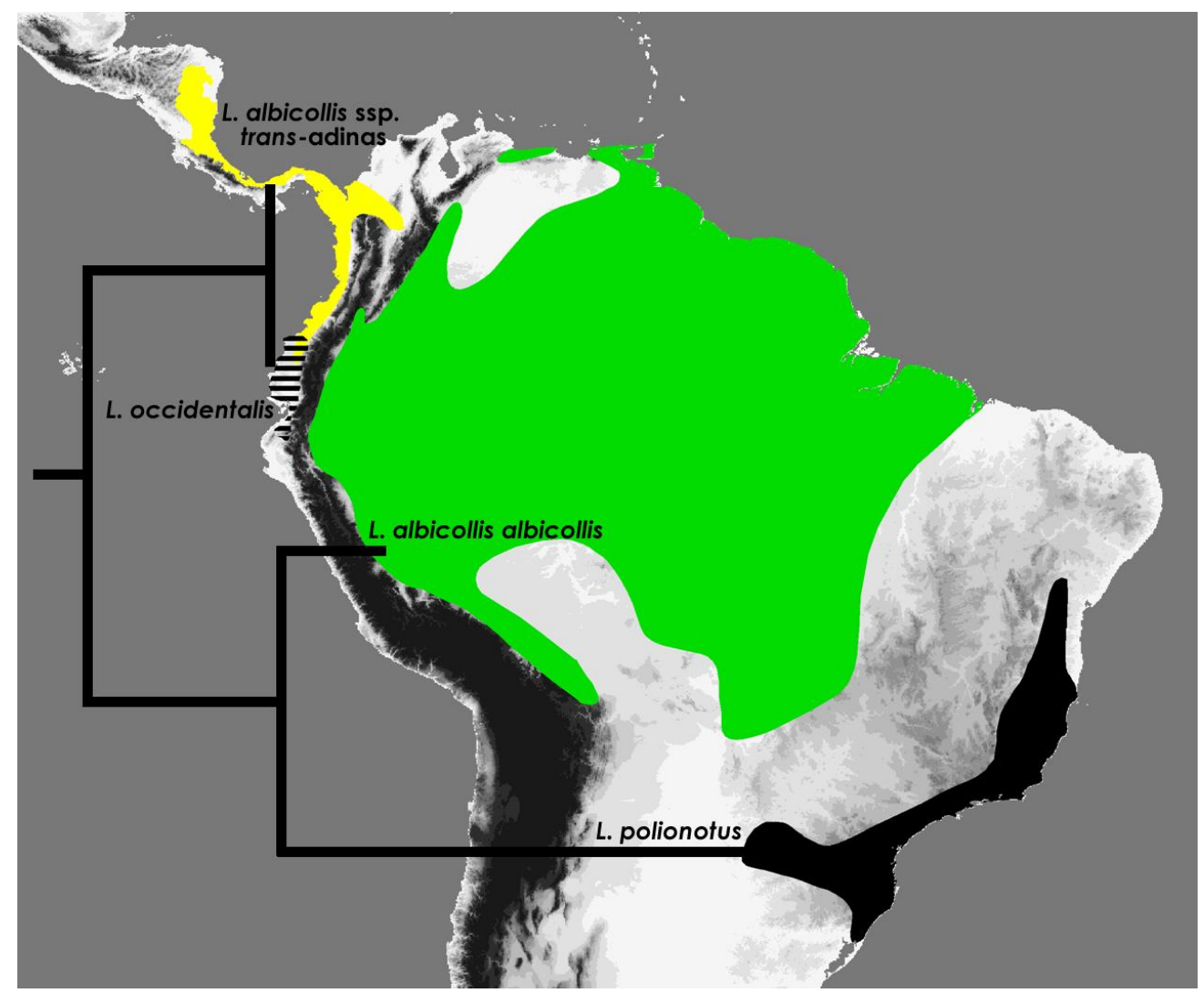

Figura 8. Mapa de distribuição e relações de Leucopternis albicollis, L. occidentalis e $L$. polionotus. As subespécies trans-andinas foram reunidas em uma mancha de distribuição, e correspondem a L. a. costaricensis, L. a. ghiesbregthi e L. a. williaminae (este último não amostrado). As distribuições utilizadas são oriundas da base de dados Infonatura (2007). 
A geração de condições de alopatria que podem ter levado à distribuição de linhagens irmãs em lados opostos dos Andes são explicadas por três teorias distintas, das quais podem ser derivadas premissas testáveis por meio de estimativas de tempo de divergência (BRUMFIELD \& CAPARELLA, 1996; BRUMFIELD \& EDWARDS, 2007), embora não sem limitações (RIBAS et al., 2005). A Hipótese do Soerguimento dos Andes (CHAPMAN, 1917) sugere a separação de populações ancestrais distribuídas inicialmente a leste e oeste dos Andes por meio do processo de orogênese da cordilheira. Esta hipótese apresenta como premissa temporal a concordância das especiações com o período de soerguimento da porção norte das Cordilheiras Ocidental, Central e Oriental, no noroeste da América do Sul. Já a Hipótese dos Refúgios (HAFFER, 1969) sugere a existência de corpos florestais ligando lados opostos dos Andes pela porção norte da cordilheira em períodos quentes e úmidos; expansões e retrações destes corredores de acordo com flutuações climáticas poderiam gerar colonizações e condições de alopatria, respectivamente, e levar à especiação. As premissas temporais deste modelo são pouco definidas; embora inicialmente propostos como responsáveis pela diversificação durante o Pleistoceno (HAFFER, 1969), os refúgios florestais seriam livres de restrições temporais (HAFFER, 1993). Entretanto, em um estudo sobre a evolução da fauna do Chocó o autor sugeriu que a diversificação por meio deste mecanismo se daria apenas após o soerguimento dos Andes, e predominantemente durante ou após o Pleistoceno (HAFFER, 1967). Finalmente o terceiro modelo, chamado Hipótese da Dispersão sobre os Andes (CHAPMAN, 1917; HAFFER, 1967) propõe que eventos de dispersão de longa distância sobre os Andes seriam responsáveis pela especiação e, embora táxon-específicos, estes eventos ocorreriam somente após o soerguimento final dos Andes (BRUMFIELD \& EDWARDS, 2007).

Embora o soerguimento dos Andes tenha iniciado há mais de 20 milhões de anos atrás, como resultado da convergência das placas tectônicas de Nazca e da América do Sul (MONTGOMERY et al., 2001), dados geológicos indicam que a fase final de soerguimento, alcançando altitudes comparáveis às atuais ocorreu entre 6 e 2.7 milhões de anos atrás (GREGORYWODZICKI, 2000). Desta forma, assumindo as premissas dos modelos supracitados são consideradas divergências anteriores a 2.7 milhões de anos 
atrás como mais provavelmente relacionados ao soerguimento dos Andes, enquanto divergências mais recentes como efeitos de refúgios florestais ou eventos de dispersão de longa distância (BRUMFIELD \& CAPARELLA, 1996; BRUMFIELD \& EDWARDS, 2007).

Assumindo um ancestral cis-andinos para as linhagens irmãs dos táxons trans-andinos representados nos nós E e F (Figura 4), é possível postular com base nas datações obtidas que a Hipótese do Soerguimento dos Andes é a melhor explicação para estas disjunções. Estas especiações são bem mais antigas que os 2,7 milhões de anos assumidos como limite temporal para o fim da orogênese dos Andes, ocorrendo durante o Mioceno. Por outro lado, os intervalos de confiança das estimativas de tempo de divergência nas disjunções C e D (Figuras 4 e 5) compreendem datas anteriores e posteriores ao limite de 2,7 milhões de anos, o que não permite inferir a participação predominante de qualquer um dos três processos discutidos. Desta forma, conclui-se que o soerguimento dos Andes pode ter participado da diversificação de linhagens basais de gaviões buteoninos, mas no entanto eventos geológicos, de dispersão e refúgios são igualmente prováveis na diversificação de linhagens trans e predominantemente cis-andinas mais recentes do grupo. Apesar dos largos intervalos de confiança obtidos, as estimativas de tempo de divergência são congruente com datações obtidas de espécies ou linhagens cis e trans-andinas de outros grupos de aves, como por exemplo: Mioceno Superior, Gypopsitta (RIBAS et al., 2005); entre o Mioceno Superior e Plioceno Inferior, Crax (PEREIRA, S. \& BAKER, 2004); entre o Plioceno e o Pleistoceno; linhagens de espécies de Thamnophilus (BRUMFIELD \& EDWARDS, 2007) e diversificação Pleistocênica entre Thamnophilus praecox e Thamnophilus nigriceps (BRUMFIELD \& EDWARDS, 2007).

\subsubsection{Diversificação em ambientes ripários, alagados e costeiros}

A diversificação de espécies de aves predominantemente distribuídas em habitats ripários, alagados e costeiros tem sido pouco contemplada em estudos evolutivos envolvendo aves neotropicais (veja alguns dos poucos exemplos em ALEIXO, 2002; ALEIXO, 2006). Entre os gaviões buteoninos, cinco espécies ocorrem de forma quase exclusiva nestes ecossistemas de acordo 
com Fergusson-Lees e Christie (2001). As espécies Busarellus nigricollis e Rostrhamus sociabilis ocupam habitats alagados por grande parte da região Neotropical, tanto em regiões costeiras como no interior do continente. Distribuições mais restritas, por outro lado, são apresentadas por Leucopternis schistaceus, que ocorre em florestas de várzea na Amazônia; Buteogallus anthracinus, que pode ser encontrado em habitats associados à água, na maior parte costeiros, do sul da América do Norte ao norte da América do Sul; e Buteogallus aequinoctialis, de dieta especializada em caranguejos, que figura como o único acipitrídeo (dada a aparente falta de validade do táxon B. a. subtilis) e uma das poucas espécies de aves de distribuição restrita a manguezais na região Neotropical. Desta forma, a análise do posicionamento filogenético destas espécies, associada às estimativas de tempo de divergência, proporcionam uma oportunidade de avaliar padrões e processos de diversificação nestes habitats.

A composição da avifauna de manguezais neotropicais inclui um grande número de aves florestais, o que pode indicar similaridades ecológicas entre estes habitats. Espécies presentes em manguezais (e.g. Conirostrum bicolor, Eudocimus ruber), por exemplo, ocorrem também em florestas de várzea da Amazônia (SICK, 1997). O relacionamento irmão do complexo B. aequinoctialis + B. anthracinus a Leucopternis schistaceus sugere não apenas similaridades ecológicas, mas ligações históricas entre estes ecossistemas (figura 9). Os tempos de divergência obtidos sugerem que a separação de Leucopternis schistaceus do ancestral de Buteogallus aequinoctialis/Buteogallus anthracinus ocorreu entre o fim do Mioceno e o Plioceno, enquanto a separação das duas últimas espécies é recente, ocorrendo apenas durante o Pleistoceno. Estas especiações são concordantes com processos geológicos e flutuações climáticas que afetaram a região Neotropical durante estes períodos. 


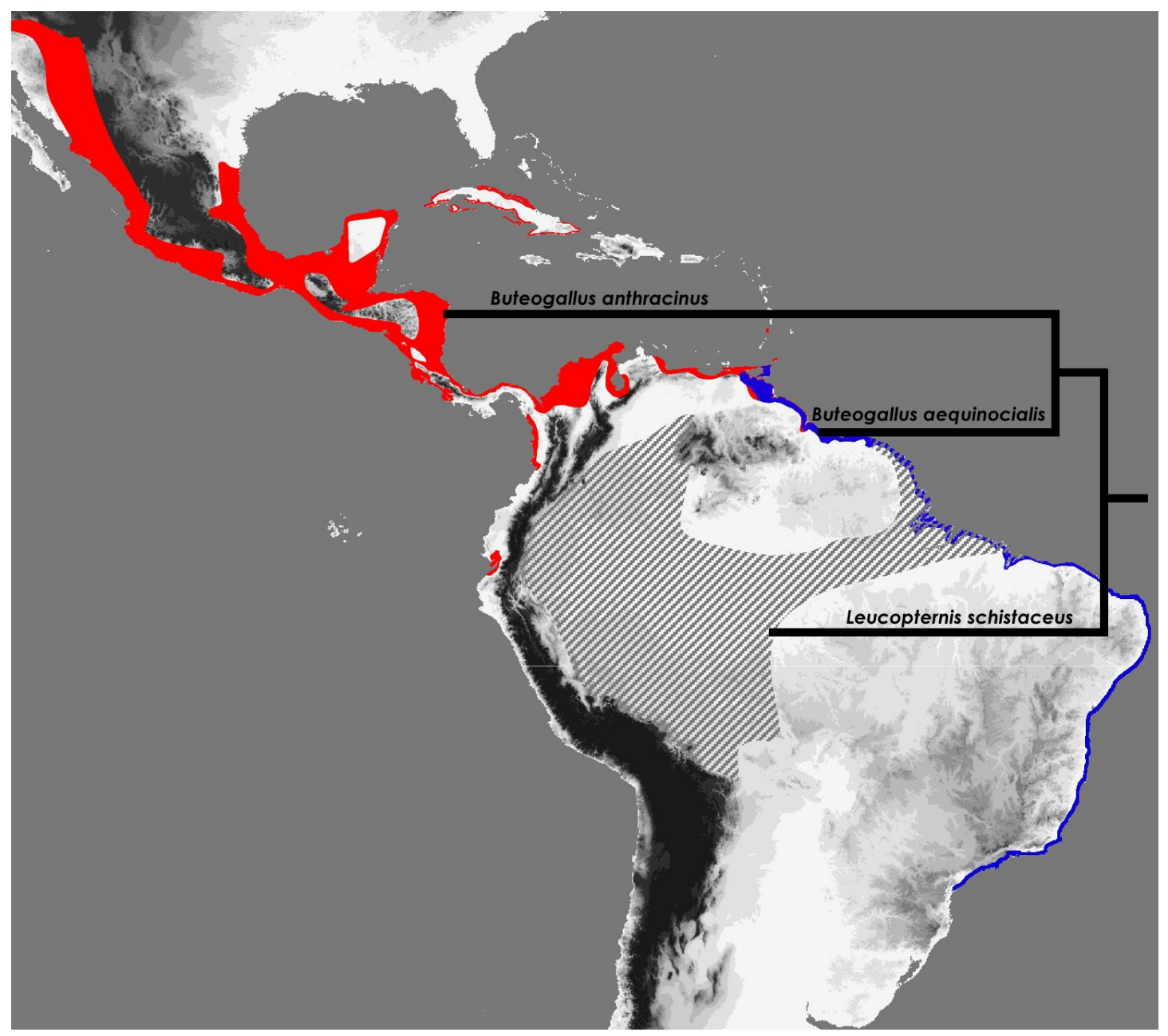

Figura 9. Mapa de distribuição e relações de Buteogallus anthracinus, Buteogallus aequinoctialis e Leucopternis schistaceus. As distribuições utilizadas são oriundas da base de dados Infonatura (2007). Devido a distribuição incompleta de B. aequinoctialis na base de dados original, esta distribuição foi editada de acordo com Fergusson-Lees e Christie (FERGUSON-LEES \& CHRISTIE, 2001).

O oeste da Amazônia experimentou o desenvolvimento de extensivos sistemas fluvio-lacrustrinos durante o Mioceno, resultado de subsidência do terreno como conseqüência do processo de orogênese dos Andes (LUNDBERG et al., 1998; ROSSETI et al., 2005; ALEIXO \& ROSSETTI, 2007). Um extenso corpo de água, denominado Lago Pebas, cobriu grande parte do oeste da Amazônia, perdurando até o fim do Mioceno (ALEIXO \& ROSSETTI, 2007). Registros de microforaminíferos, dinoflagelados e pólen de mangue nesta região sugerem transgressões marinhas episódicas durante este período (HOORN et al., 1995). Com base nestes eventos, Aleixo e Rossetti (2007) sugeriram que o oeste da Amazônia representaria uma área de expansão de espécies de florestas de várzea até o final do Mioceno, momento a partir do qual teria havido início a colonização de linhagens de terra-firme de áreas 
adjacentes devido a mudança do tipo de habitat predominantemente, em ciclos de substituição de floresta de terra-firme e várzea. Por outro lado, Hooghiemstra e van der Hammer (1998) postularam que alterações espaciais e temporais entre ecossistemas de água doce e salgada, resultantes de trangressões marinhas episódicas, podem ter relação com a evolução da diversidade de algumas áreas da América do Sul. Ambas hipóteses são congruente com a diversificação do clado L. schistaceus/ B. aequinoctialis/ B. anthracinus. Um cenário provável consiste na existência de uma espécie ancestral de ocorrências em matas de várzea, que pode ter se expandido a partir do oeste da Amazônia para grande parte do território compreendido atualmente pelo bioma Amazônia e habitats costeiros adjacentes, devido a uma maior disponibilidade de habitat até o final do Mioceno. Devido ao desaparecimento do Lago Pebas, e à reorganização do sistema fluvial da Amazônia entre o fim do Mioceno e o Plioceno (ROSSETl et al., 2005; ALEIXO \& ROSSETTI, 2007), a diminuição de habitats disponíveis pode ter fragmentado a distribuição deste ancestral em uma espécie de vázea Amazônica (Leucopternis schistaceus) e outra costeira (ancestral de Buteogallus aequinoctialis/anthracinus). Posteriormente, a separação entre $B$. aequinoctialis e $B$. anthracinus pode ter sido causada por uma reorganização da distribuição de habitats costeiros, resultante de flutuações do nível do mar e do clima durante o Quartenário (WOODROFFE \& GRINDROD, 1991). A especialização de $B$. aequinoctialis em explorar manguezais, relacionada à dieta exclusivamente baseada em caranguejos (FERGUSON-LEES \& CHRISTIE, 2001), pode ter ocorrido após a separação de B. anthracinus, enquanto este último continuou a explorar tanto manguezais como outros habitats alagados em sua distribuição. A existência de um fóssil do Holoceno encontrado na Jamaica e atribuído a Buteogallus aequinoctialis (OLSON, 2006) sugere que esta espécie pode ter sido mais amplamente distribuída em um passado recente. A dimuição da área de ocorrência desta espécie para a condição atual pode estar relacionada à competição com B. anthracinus, o que seria congruente com a pequena área de simpatria entre as duas espécies, ou mudanças na distribuição de habitat adequado (OLSON, 2006).

A maior proximidade da espécie de floresta de várzea às espécies predominantemente costeiras, ao invés de espécies de terra firme da 
Amazônia (e.g. L. melanops/L. kuhli, L. albicollis albicollis) suporta a idéia de histórias evolutivas independentes entre linhagens de espécies de florestas de várzea e florestas de terra firme da Amazônia, padrão similar ao encontrado em Xyphorhynchus (ALEIXO, 2006). Por outro lado, as espécies restantes de habitats ripários/alagados neotropicais, Rostrhamus sociabilis e Busarellus nigricollis, pertencem a uma linhagem não diretamente relacionada ao grupo de L. schistaceus, mas que também contém Geranospiza caerulescens, espécie que ocupa habitats diversos mas que é encontrada com maior freqüência próximo à corpos de água (FERGUSON-LEES \& CHRISTIE, 2001). Desta forma, espécies de habitats alagados estão presentes em dois clados monofiléticos que não são diretamente relacionados, o que representa uma história de diversificação restrita a estes ambientes, e que ocorreu duas vezes durante a evolução dos gaviões buteoninos.

Embora as relações dentro do clado de Rostrhamus, Busarellus e Geranospiza não tenham sido definidas com precisão, o tamanho do ramo conectando estas espécies ao restante do grupo aponta um longo processo de diversificação desta linhagem (Mioceno, Figuras 4 e 5), suportando a idéia de algumas linhagens de aves de áreas alagadas serem relitos de radiações neotropicais antigas (ALEIXO, 2006; ALEIXO \& ROSSETTI, 2007). No entanto, O surgimento mais recente da linhagem do clado de floresta de várzea/habitats costeiros aponta uma periodicidade do processo de diversificação em habitats alagados, ocorrendo em diversos momentos da história da biota neotropical.

\subsubsection{O efeito de rios como promotores de diversificação na Amazônia}

Se por um lado espécies que ocupam habitats ripários, lacustres e costeiros se beneficiam da expansão destes ambientes, o desenvolvimento de rios e vegetações ribeirinhas associadas pode ter importância no isolamento de aves florestais que ocupam florestas não alagadas (florestas de terra-firme). Este processo tem sido considerado há mais de 100 anos como um dos potenciais fatores afetando a diversificação de espécies florestais de terra-firme da Amazônia, dada a coincidência da distribuição de espécies em margens opostas de grandes rios (WALLACE, 1852). As espécies 
Leucopternis kuhli e Leucopternis melanops foram tidas por alguns autores como exemplos claros de disjunção de espécies ao sul e norte do rio Amazonas (HAFFER, 1987). Sob este cenário, seria possível postular uma possível participação do rio Amazonas como uma barreira primária (causando a especiação) ou secundária (mantendo a distribuição) deste par de espécies. No entanto, estudos recentes baseados em registros históricos e recentes sugerem a presença de Leucopternis melanops em diversas localidades ao sul do rio Amazonas (BARLOW et al., 2002; AMARAL et al., 2007), com ampla sobreposição com a distribuição de Leucopternis kuhli. Estes dados sugerem que o rio Amazonas em sua conformação atual não representa um obstáculo para a dispersão de indivíduos entre os dois lados de suas margens, pelo menos no caso de L. melanops. A configuração atual de drenagem transcontinental do rio Amazonas com conexão com o oceano Atlântico já existia no final do Mioceno há cerca de 8 milhões de anos atrás como resultado da orogênese dos Andes (LUNDBERG et al., 1998), após um longo período de drenagem do sistema fluvial amazônico para o Caribe (HOORN et al., 1995). Desta forma, não é possível associar a separação de Leucopternis melanops e Leucopternis kuhli à formação do rio Amazonas, já que os resultados sugerem que a separação das duas espécies é bem mais recente (Pleistoceno). Dois cenários distintos, mas não excludentes, podem ser postulados com base nestas informações. É possível que o rio Amazonas tenha funcionado como barreira no passado em períodos de nível do mar mais elevado (NORES, 1999), o que pode ter bloqueado populações de terra firme ao sul e ao norte do rio. Posteriormente, a diminuição do nível do mar pode ter reduzido a importância deste rio como barreira para dispersão, trazendo as duas populações já diferenciadas em contato. Por outro lado, a separação destas duas espécies durante o Pleistoceno não rejeita a Teoria dos Refúgios (HAFFER, 1969). Sob esta hipótese, é possível que tenha ocorrido a fragmentação de ilhas de habitat propício para o ancestral das duas espécies, circundada por savana (HAFFER, 1969) ou tipos florestais inadequados para a espécie ancestral (COLINVAUX, 1998), levando a diferenciação destas espécies. Em épocas mais úmidas e quentes, as espécies já diferenciadas podem ter expandido suas distribuições e entrado 
em contato. Um terceiro cenário possível combinaria os dois processos de forma simultânea, como de acordo com a Teoria dos Rios-Refúgios (HAFFER, 1997). Assim, a especiação de Leucopternis kuhli e Leucopternis melanops pode ter sido causada pelo rio Amazonas em uma configuração distinta da atual, por refúgios florestais, ou por ambos os processo combinados.

\subsubsection{Mudanças de habitat e relações entre áreas de endemismo na região Neotropical}

As relações filogenéticas inferidas entre as espécies neotropicais suportam uma multiplicidade de conexões históricas entre habitats abertos e florestais. Os conjuntos de táxons ocupando predominantemente estes dois tipos de habitats não formam clados reciprocamente monofiléticos, padrão já indicado com menor amostragem taxonômica em Amaral et al. (2006). No entanto, agrupamentos mais restritos de espécies florestais ou abertas puderam ser observados. Entre os clados predominantemente florestais, é possível citar: complexo Leucopternis albicollis/L. occidentalis/L. polionotus; complexo Leucopternis semiplumbeus/L. melanops/L. kuhli; e Harpagus diodon/H. bidentatus. Por outro lado, apenas um único clado reúne espécies predominantemente distribuídos em áreas abertas, e que inclui Buteo albicaudatus, Buteo polyosoma e Geranoaetus melanoleucus. Estas linhagens restritas a um mesmo tipo de habitat encontram-se espalhadas em diversos pontos da topologia, intercaladas por um contínuo que varia de espécies altamente florestais (e.g. restante das espécies de Leucopternis) a espécies que ocupam habitats diversos (e.g. Buteo magnirostris) e áreas abertas (e.g. Parabuteo unicinctus), e que em alguns casos estão agrupadas em clados mistos (e.g. clado F, figura 4). Em uma escala mais fina, também é possível observar espécies irmãs que apresentam este mesmo padrão, como $L$. lacernulatus e B. meridionalis, (floresta/savana), Harpyhaliaetus solitarius e $H$. coronatus (florestas úmidas montanas/savana) e Parabuteo unicintus e Buteo leucorrhous (savanas/florestas úmidas), representando especiações que ocorreram durante períodos distintos como no Mioceno ou Plioceno no caso dos dois primeiros pares, ou tão recentemente como no Pleistoceno, no caso das espécies de Harpyhaliaetus. Este padrão sugere que transições de habitat ocorreram em períodos antigos e recentes da diversificação do 
grupo, gerando não só algumas linhagens completamente distribuídas em habitats específicos, como também pares de espécies que ocupam ecossistemas radicalmente diferentes. Os resultados, desta forma, corroboram a existência de uma plasticidade ecológica durante a evolução dos gaviões buteoninos, além de uma história dinâmica de diversificação da avifauna de habitats abertos e florestas (GARCÍA-MORENO \& CARDOSO DA SILVA, 1997), com interações durante múltiplos períodos da diversificação da biota neotropical. No caso das espécies irmãs habitando áreas abertas e florestais, cenários envolvendo tanto modos de especiação alopátrica (Teoria dos "Vanishing Refuges" VANZOLINI \& WILLIAMS, 1981), ou parapátrica (Teoria dos gradientes, ENDLER, 1982) podem ter operado na diversificação. Embora não sejam diferenciáveis apenas com base na filogenia, os dois processos podem ter sido facilitados por efeitos resultantes de flutuações climáticas cíclicas, por meio da substituição entre habitats abertos e florestais.

Embora a maioria das espécies de gaviões buteoninos neotropicais apresente distribuições muito mais amplas que as propostas para áreas de endemismo na região, algumas conclusões gerais emergem dos dados. De forma similar aos habitats abertos e florestais, biomas e áreas de endemismo apresentam uma multiplicidade de relações com áreas distintas. As duas únicas espécies de gaviões buteoninos endêmicas da Mata Atlântica Leucopternis polionotus e Leucopternis lacernulatus, por exemplo, não são proximamente relacionados. Este padrão corrobora uma história complexa de diversificação, já sugerido em outros grupos de vertebrados (CRACRAFT \& PRUM, 1988; BATES et al., 1998; COSTA, 2003; NYÁRI, 2006; RIBAS et al., 2006). Com base no posicionamento filogenético destas espécies, duas conexões são sugeridas com biomas distintos. O relacionamento irmão de Leucopternis polionotus e Leucopternis a. albicollis indica uma conexão entre Amazônia e a Mata Atlântica. Esta ligação pode ter sido interrompida entre o fim do Plioceno ou no Pleistoceno, levando à especiação a partir de uma espécie amplamente distribuída nestes dois grandes blocos florestais, hoje separados pela "diagonal seca" composta pelos biomas abertos do Chaco, Cerrado e Caatinga. A conexão entre estes biomas pode ter ocorrido no norte da Mata Atlântica, por meio de corredores que cruzaram a caatinga desde o Terciário tardio (RIZZINI, 1963; ANDRADE-LIMA, 1964), no sul da Mata Atlântica por meio 
de conexões com o sudeste da Amazônia (BIGARELLA et al., 1975), ou ainda pelo Brasil Central, por meio de matas de galeria (COSTA, 2003). Por outro lado, a relação de Leucopternis lacernulatus a uma espécie de savana amplamente distribuída sugere o relacionamento histórico da Mata Atlântica não apenas como outros biomas florestais, mas também com savanas. Esta última conexão é congruente com relações encontradas em aves da diagonal aberta e da Mata Altântica em uma análise recente de distribuições e endemismo (PORZECANSKI \& CRACRAFT, 2005), assim como a alta influência florística da Mata Atlântica em um dos biomas da diagonal aberta, o Cerrado (MÉlO et al., 2003). Esta mutiplicidade na história da floresta Atlântica também reflete nas relações entre espécies amazônicas de terra-firme e do Chocó (área de endemismo que compreende florestas úmidas sul-americanas a oeste dos Andes). Desta forma enquanto o clado do complexo L. albicollis/L. polionutus/L.occidentalis (Figura 8) sugere a relação ((Amazônia,Floresta Atlântica), (Chocó, América Central)), o complexo L. semiplumbeus/L. melanops/L.kuhli (Figura 7) sugere a relação ((Amazônia), (Choco, América Central). Assim, apesar de pertencerem a linhagens distintas, as aves Amazônicas, do Chocó e América Central apresentam relação similares, com exceção da inclusão da Mata Atlântica nas relações do complexo L. albicollis/L.occidentalis/L.polionotus. As demais espécies trans-andinas (L. plumbeus e L. princeps) são basais a clados predominantemente cis-andinos, e são pouco informativos sobre relações de áreas de endemismo, dada a ampla distribuição combinada destes clados.

Embora o clado de G. melanoleucus, B. polyosoma e B. albicaudatus represente a geração e diversificação do único clado monofilético de espécies do grupo distribuídas predominantemente em savanas da América do Sul (e no caso de B. albicaudatus, também na América Central), as amplas distribuições destes táxons não permitem conclusões sobre a relação entre áreas aberta no continente. No entanto, eventos de especiação que geraram estas espécies parecem ter ocorrido entre o Mioceno e o Pleistoceno. Uma das explicações possíveis para a diversificação neste clado pode estar relacionada à maior conexão entre corpos florestais na região Neotropical no passado. Ao mesmo tempo que estas conexões podem ter ligaram biomas florestais úmidos, elas podem ter também fragmentado a 
distribuição de paisagens abertas no continente, promovendo a diversificação de espécies de savana.

\subsection{Nomenclatura}

Com base nos resultados apresentado aqui e em trabalhos anteriores (RIESING et al., 2003; AMARAL et al., 2006; LERNER et al., no prelo), a necessidade de uma revisão nomenclatural torna-se evidente, já que a classificação atual (REMSEN JR. et al., 2007) não reflete a história evolutiva do grupo. São propostas as seguintes modificações como forma de alinhar a classificação e nomenclatura dos gaviões buteoninos com os grupos monofiléticos recuperados nas análises filogenéticas inferidos:

Buteo Lacépedè, 1799: como em muitos gêneros de buteoninos, uma diagnose morfológica clara ainda não foi proposta, em função dos padrões complexos de variação de plumagem dos representantes atualmente alocados neste gênero. Com base nos resultados obtidos, propõe-se que Buteo Lacépedè, 1799 seja restrito às espécies delimitadas pelo nó B (figura 4), com as espécies mais basais deste gênero sendo B. platypterus, B. nitidus, B. lineatus e B. ridgwayi. Este gênero assim representaria uma linhagem predominantemente holártica e de áreas abertas, mas também incluindo espécies neotropicais que fizeram parte da radiação mais recente de gaviões buteoninos. Não foi possível resolver aqui o posicionamento de Buteo nitidus, como em análises anteriores (LERNER et al., no prelo), o que torna incerta a relação mais próxima desta espécie ao restante dos táxons definidos pelo nó B ou ao clado de Leucopternis melanops, Leucopternis kuhli e Leucopternis semiplumbeus. Embora B. nitidus tenha sido, por muito tempo, mantido no gênero Asturina Vielliot, 1816 por alguns autores (e. g. AMADON, 1982), sugere-se que a espécie seja provisoriamente mantida no gênero, como atualmente adotado (COMITE BRASILEIRO DE REGISTROS ORNITOLÓGICOS, 2007; REMSEN JR. et al., 2007), até que este posicionamento possa ser definido com maior precisão.

Leucopternis Kaup, 1847: este gênero, como atualmente aceito (COMITÊ BRASILEIRO DE REGISTROS ORNITOLÓGICOS, 2007; REMSEN JR. et al., 2007), se mostrou polifilético tanto no presente trabalho como em outras 
análises filogenéticas recentes (AMARAL et al., 2006; LERNER et al., no prelo). Com base nestes resultados, sugere-se que Leucopternis Kaup, 1847 seja restringido às espécies Leucopternis melanops (Latham, 1790), Leucopternis semiplumbeus Lawerence, 1861 e Leucopternis kuhli Bonaparte, 1850. A manutenção dos demais componentes tradicionalmente alocados neste gênero, entre eles L. albicollis, L. occidentalis e L. polionotus, torna-o parafilético. Desta forma, sugere-se a transferência das espécies acima citadas para o gênero Pseudastur Gray, 1849, cuja espécie-tipo corresponde a Leucopternis albicollis, e que seria assim composto pelas espécies Pseudastur albicollis (Latham, 1790), Pseudastur polionotus (Kaup, 1847) e Pseudastur occidentalis (Salvin, 1876). As subespécies de Pseudastur albicollis não se mostraram aqui reciprocamente monofiléticas, sendo Pseudastur occidentalis mais proximamente relacionado às subespécies trans-andinas de Pseudastur albicollis do que a Pseudastur albicollis albicollis, que é irmão de Pseudastur polionotus. Desta forma, uma ampla revisão taxonômica é necessária para a melhor definição dos limites específicos entre $P$. occidentalis e subespécies trans-andinas de $P$. albicollis, assim como modificações nomenclaturais envolvendo estes táxons.

Geranoaetus Kaup, 1844: com a reorganização de Buteo como sugerido acima, a manutenção de B. polyosoma e B. albicaudatus neste gênero torna-o parafilético. Sugere-se aqui a inclusão destas espécies no gênero Geranoaetus Kaup, 1844, que seria então composto pelas espécies Geranoaetus melanoleucus (Vieillot, 1819), Geranoaetus albicaudatus (Vieillot, 1816) e Geranoaetus polyosoma (Quoy \& Gaimard, 1824).

Percnohierax Ridgway, 1920, Parabuteo Ridgwayi, 1874, Morphnarchus Ridgwayi, 1920 e Rupornis Kaup, 1844: Em relação às espécies atualmente incluídas em Buteo não citadas nos parágrafos anteriores, sugerimos que Buteo magnirostis seja incluído em Rupornis Kaup, 1844, e Buteo leucorrhous seja transferido para o gênero monotípico Percnohierax Ridgway, 1920, conforme já sugerido por outros autores (RIESING et al., 2003). A manutenção destas duas espécies em Buteo não é justificável dada a quantidade de táxons que, segundo a análise aqui apresentada, seriam necessários para tornar o gênero Buteo monofilético. Este arranjo é compatível com a manutenção do gênero Parabuteo Ridgway, 1874, que incluiria apenas a 
espécie Parabuteo unicinctus (Temminck, 1824). De forma similar, Leucopternis princeps aparece isolada na topologia, e sugerimos a transferência desta espécie para o gênero Morphnarchus Ridgway, 1920, também com apenas uma espécies, Morphnarchus princeps (Sclater, 1865).

Buteogallus Lesson, 1830: de forma similar ao observado em Buteo e Leucopternis, Buteogallus não é um gênero monofilético. Sugerem-se aqui duas propostas nomenclaturais alternativas. A primeira seria a manutenção de B. aequinoctialis, B. anthracinus, e inclusão de L. schistaceus em Buteogallus; transferência de L. lacernulatus e B. meridionalis para Heterospizias Sharpe 1847; transferência de Buteogallus urubitinga para Harpyhaliaetus Lafresnay, 1842; e finalmente, a criação de um novo gênero monotípico para Leucopternis plumbeus. Uma segunda solução, mais simples, também pode ser proposta. As espécies Leucopternis schistaceus, L. lacernulatus, L. plumbeus, Harpyhaliaetus coronatus e H. solitarius seriam transferidas para o gênero Buteogallus, que já conta com as espécies $B$. aequinoctialis, B. meridionalis, B. anthracinus e B. urubitinga. Esta solução elimina a necessidade de criação de um gênero monotípico para $L$. plumbeus. Entre os argumentos a favor deste último rearranjo estão: $L$. plumbeus e L. schistaceus apresentam padrões muito similares de plumagem, e a relação próxima à espécies atualmente incluídas em Buteogallus foi sugerida diversas vezes na literatura (RIDGWAY, 1876; AMADON, 1982; BROWN \& AMADON, 1989); o tamanho foi um dos poucos argumentos favoráveis à manutenção de $H$. solitarius e $H$. coronatus em um gênero separado de $B$. urubitinga (AMADON \& ECKELBERRY, 1955), apesar da similaridade de plumagem destas três espécies, em especial entre $H$. soltarius e $B$. urubitinga. Julga-se aqui a segunda proposta como a mais apropriada, que inclui todas as espécies do clado F (figura 4) em Buteogallus. Desta forma, sugerimos a utilização de Buteogallus anthracinus (Deppe, 1830), Buteogallus aequinoctialis (Gmelin, 1788), Buteogallus schistaceus (Sundevall, 1851), Buteogallus solitarius (Tschudi, 1844), Buteogallus coronatus (Viellot, 1817), Buteogallus urubitinga (Gmelin, 1788), Buteogallus lacernulatus (Temminck, 1827), Buteogallus meridionalis (Latham, 1790) e Buteogallus plumbeus (Salvin, 1872). 


\section{Referência bibliográficas}

ALEIXO, A. Molecular systematics and the role of the "várzea"-"terrafirme" 'ecotone in the diversification of Xiphorhynchus woodcreepers (Aves: Dendrocolaptidae). Auk, v. 119, n. 3, p. 621-640. 2002.

Historical diversification of floodplain specialist species in the Amazon: a case study with two species of the avian genus Xyphorhynchus (Aves: Dendrocolaptidae). Biological Journal of the Linnean Society, v. 89, n. 2, p. 383-395. 2006.

ALEIXO, A., ROSSETTI, D. F. Avian gene trees, landscape evolution, and geology: towards a modern synthesis of Amazonian historical biogeography? Journal of Ornithology, v. 148 (Suppl. 2), p. S443-S453. 2007.

AMADON, D. Notes on Harpyhaliaetus. Auk, v. 66, p. 53-56. 1949.

Taxonomic notes on birds of prey. American Museum Novitates, v. 2166, p. 1-24. 1964.

A revision of the sub-buteonine hawks (Accipitridae, Aves). American Museum Novitates, v. 2741, p. 1-20. 1982.

AMADON, D., BULL, J. Hawks and owls of the world: a distributional and taxonomic list. Western Foundation of Vertebrate Zoology, v. 3, n. 4, p. 295-357. 1988.

AMADON, D., ECKELBERRY, D. R. Observations on Mexican birds. The Condor, V. 57, n. 2, p. 65-80. 1955.

AMARAL, F. S. R., MILLER, M. J., SILVEIRA, L. F., BERMINGHAM, E., WAJNTAL, A. Polyphyly of the hawk genera Leucopternis and Buteogallus (Aves, Accipitridae): multiple habitat shifts during the Neotropical buteonine diversification. BMC Evolutionary Biology, v. 6, p. 10. 2006.

AMARAL, F. S. R., SILVEIRA, L. F., WHITNEY, B. M. New localities for the Blackfaced Hawk (Leucopternis melanops) south of the Amazon River and description of the immature plumage of the White-browed Hawk (Leucopternis kuhli). The Wilson Journal of Ornithology, v. 119, n. 3, p. 450-454. 2007.

ANDRADE-LIMA, D. Contribuição à dinâmica da flora do Brasil. Arquivos do Instituto de Clências da Terra, v. 2, n. 15-20. 1964.

ARBOGAST, B. S., EDWARDS, S. V., WAKELEY, J., BEERLI, P., SLOWINSKI, J. B. Estimating divergence times from molecular data on phylogenetic and population genetics timescales. Annual Review of Ecology and Systematics, v. 33, p. 707-740. 2002. 
BALLMAN, P. Les oiseaux miocènes de La Grive-Saint-Alban(Isère). Géobios, v. 2, p. 157-204. 1969.

BANKS, R. C., CHESSER, R. T., CICERO, C., DUNN, J. L., KRATTER, A. W., LOVETTE, I. J., RASMUSSEN, P. C., REMSEN JR., J. V., RISING, J. D., STOTZ, D. F. Forty-eighth supplement to the American Ornithologists' Union Check-list of North American birds. Auk, v. 124, n. 3, p. 1109-1115. 2007.

BANKS, R. C., CICERO, C., DUNN, J. L., KRATTER, A. W., RASMUSSEN, P. C., REMSEN JR., J. V., RISING, J. D., STOTZ, D. F. Forty-seventh supplement to the American Ornithologists' Union Check-list of North American birds. Auk, v. 123, n. 3, p. 926-936. 2006.

BARLOW, J., T, H., PERES, C. Sympatry of the Black-faced Hawk Leucopternis melanops and the White-Browed Hawk Leucopternis kuhli in the lower rio Tapajós, Pará, Brazil. Cotinga, v. 18, p. 77-79. 2002.

BARROWCLOUGH, G. F., GROTH, J. G., MERTZ, L. A. The RAG-1 exon in the avian order Caprimulgiformes: phylogeny, heterozygosity, and base composition. Molecular Phylogenetics and Evolution, v. 41, n. 1, p. 238-248. 2006.

BATES, J. M., HACKETT, S. J., CRACRAFT, J. Area-relationships in the Neotropical Lowlands: an hypothesis based on raw distributions of Passerine birds. Journal of Biogeography, v. 25, n. 4, p. 783-793. 1998.

BERTHOLD, P. A comprehensive theory for the evolution, control and adaptability of avian migration. Ostrich, v. 70, n. 1-11. 1999.

BIGARELLA, J. J., ANDRADE-LIMA, D., RIEHS, P. J. Considerações a respeito das mudanças paleoambientais na distribuição de algumas espécies vegetais $e$ animais no Brasil. Anais da Academia Brasileira de Ciências, v. 47, n. 411-464. 1975.

BILDSTEIN, K. L. Raptor migration in the Neotropics: patterns, processes and consequences. Ornitologia Neotropical, v. 15 (Suppl.), p. 83-99. 2004.

BILDSTEIN, K. L., ZALLES, J. I. Old World versus New World long-distance migration in Accipiters, Buteos, and Falcons: The interplay of migration ability and global biogeography. In: GREENBERG, R. e MARRA, P. P. (org). Birds of two worlds: the ecology and evolution of migration. . Baltimore: The Johns Jopkins University Press, 2005. p. 154-167.

BOEV, Z. N., KOVACEV, D. Buteo spassovi sp. n. - a late Mionece buzzard (Accipitridae, Aves) from SW Bulgaria. Geologica Balcanica, v. 29, p. 125-129. 1998.

BROWN, L., AMADON, D. Eagles, hawks and falcons of the world. London: Spring Books. 1989. 945 p. 
BRUFORD, M. W., HANNOTE, O., BROOKFIELD, J. F. Y., BURKE, T. Multi and singlelocus DNA fingerprinting. In: HOEZEL, A. R. (org). Molecular genetic analysis of populations - a pratical approach. New York: IRL Press, 1992. p. 225-269.

BRUMFIELD, R. T. Mitochondrial variation in Bolivian populations of the variable antshrike (Thamnophilus caerulescens). Auk, v. 122, p. 414-432. 2005.

BRUMFIELD, R. T., CAPARELLA, A. P. Historical diversification of birds in northwestern South America: a molecular perspective on the role of vicariant events. Evolution, v. 50, n. 4, p. 1607-1624. 1996.

BRUMFIELD, R. T., EDWARDS, S. V. Evolution into and out of the Andes: a Bayesian analysis of historical diversification in Thamnophilus antshrikes. Evolution, v. 61, p. 346-367. 2007.

BURNS, K. J. Molecular phylogenetics of the genus Piranga: implications for biogeography and the evolution of morphology and behaviour. Auk, v. 115, p. 621-634. 1998.

CABANNE, G. S., SEIPKE, S. H. Migration of the Rufous-thighed Kite (Harpagus diodon) in Southeastern Brazil. Ornitologia Neotropical, v. 16, p. 547-549. 2005.

CHAPMAN, F. The distribution of bird life in Colombia. Bulletin of the American Museum of Natural History, v. 36, p. 1-729. 1917.

CHESSER, R. T. Evolution in the high Andes: the phylogenetics of Muscisaxicola Ground-Tyrants. Molecular Phylogenetics and Evolution, v. 15, p. 369-380. 2000.

CHESSER, R. T., LEVEY, D. J. Austral migrants and the evolution of migration in New World birds: diet, habitat, and migration revisited. The American Naturalist, v. 152, n. 2, p. $311-319.1998$.

CLARK, W. S. Taxonomic status and distribution of Mangrove Black Hawk Buteogallus (anthracinus) subtilis. Bulletin of the British Ornithologists Club, v. 127, n. 2, p. 110.2007.

CLARK, W. S., WITT, C. C. First known specimen of a hybrid buteo: Swainson's hawk (Buteo swainsoni) x Rough-legged Hawk (B. lagopus) from Louisiana. The Wilson Journal of Ornithology, v. 118, n. 1, p. 42-52. 2006.

COATES, A. G., OBANDO, J. A. The geologic evolution of the Central America Isthmus. In: JACKSON, J. B. C., BUDD, A. F. e COATES, A. G. (org). Evolution and environment in tropical America. Chicago: University of Chicago Press, 1996. p. 21-56.

COLINVAUX, P. A. A new vicariance model for Amazonian endemics. Global Ecology \& Biogeography Letters, v. 7, p. 95-96. 1998.

COMITE BRASILEIRO DE REGISTROS ORNITOLÓGICOS. Listas das aves do Brasil. Disponível em: http://www.cbro.org.br. Acesso em: 16 de agosto de 2007 
COOPER, A., POINAR, H. N. Ancient DNA: do it right or not at all. Science, $v$. 289, n. 5482, p. 1139.2000.

COSTA, L. P. The historical bridge between the Amazon and the Atlantic Forest of Brazil: a study of molecular phylogeography with small mammals. Journal of Biogeography, v. 30, n. 1, p. 71-86. 2003.

COX, G. W. The evolution of avian migration systems between temperate and tropical regions of the New World. The American Naturalist, v. 126, n. 4, p. 451474. 1985.

CRACRAFT, J., PRUM, R. O. Patterns and processes of diversification: speciation and historical congruence in some neotropical birds. Evolution, v. 42, n. 3, p. 603-620. 1988.

EBERHARD, J. R., BERMINGHAM, E. Phylogeny and biogeography of the Amazona ochrocepala (Aves: Psittacidae) complex. Auk, v. 121, n. 2, p. $318-$ 332. 2004.

EBERHARD, J. R., WRIGHT, T. F., BERMINGHAM, E. Duplication and concerted evolution of the mitochondrial control region in the parrot genus Amazona. Molecular Biology and Evolution, v. 18, n. 7, p. 1330-1342. 2001.

ENDLER, J. A. Problems in distinguishing historical from ecological factors in biogeography. Integrative and Comparative Biology, v. 22, n. 2, p. 441-452. 1982.

ERICSON, P. G., ANDERSON, C. L., BRITTON, T., ELZANOWSKI, A., JOHANSSON, U. S., KALLERSJO, M., OHLSON, J. I., PARSONS, T. J., ZUCCON, D., MAYR, G. Diversification of Neoaves: integration of molecular sequence data and fossils. Biology Letters, v. 2, p. 543-547. 2006.

ESPINOSA DE LOS MONTEROS, A. Models of the primary and secondary structure for the 12S rRNA of birds: a guideline for sequence alignment. DNA Sequence, v. 14, n. 4, p. 241-256. 2003.

FERGUSON-LEES, J., CHRISTIE, D. A. Raptors of the World. Boston: Houghton Mifflin. 2001. $992 \mathrm{p}$.

FLEISCHER, R. C., MCINTOSH, C. E. Molecular systematics and biogeography of the Hawaiian avifauna. Studies in Avian Biology, v. 22, p. 51-60. 2001.

FLEISCHER, R. C., OLSON, S. L., JAMES, H. F., COOPER, A. C. Identification of the extinct hawaiian eagle (Haliaeetus) by mtDNA sequence analysis. Auk, v. 117 , n. 4, p. 1051-1056. 2000.

FRIEDMANN, H. The birds of North and Middle America. Part XI. Cathartidae to Falconidae. United States National Museum Bulletin, v. 50. 1950.

GARCÍA-MORENO, J., CARDOSO DA SILVA, J. M. An interplay between forest and non-forest South American avifaunas suggested by a phylogeny of 
Lepidocolaptes woodcreepers (Dendrocolaptidae). Studies in Neotropical Fauna and Environment, v. 32, p. 164-173. 1997.

GREGORY-WODZICKI, K. M. Uplift history of the Central and Northern Andes: A review. Geologic Society of America Bulletin, v. 112, n. 7, p. 1091-1105. 2000.

GRIFFITHS, C. S., BARROWCLOUGH, G. F., GROTH, J. G., MERTZ, L. A. Phylogeny of the Falconidae (Aves): a comparision of the efficacy of morphology, mitochondrial and nulecar data. Molecular Phylogenetics and Evolution, v. 32, n. 101-109. 2004.

Phylogeny, diversity, and classification of the Accipitridae based on DNA sequences of the RAG-1 exon. Journal of Avian Biology, v. 38, n. 5, p. 587602. 2007.

GROSSMAN, M. L., HAMLET, J. Birds of prey of the world. New York: Bonanza Books. 1964. $496 \mathrm{p}$.

GUYER, M. F. On the Sex of Hybrid Birds. Biological Bulletin, v. 16, n. 4, p. 193198. 1909.

HACKETT, S. J. Molecular phylogenetics and biogeography of tanagers in the genus Ramphocelus (Aves). Molecular Phylogenetics and Evolution, $v .5, \mathrm{n}$. 368-382. 1996.

HAFFER, J. Speciation in Colombian forest birds west of the Andes. American Museum Novitates, v. 2294, p. 1-57. 1967.

137. 1969

Speciation in Amazonian Forest Birds. Science, v. 165, n. 3889, p. 131-

Biogeography of neotropical birds. In: WHITMORE, T. C. e PRANCE, G. T. (org). Biogeography and Quarternary history in tropical America. Oxford: Clarendon Press, 1987.

. Time's cycle and time's arrow in the history of Amazonia. Biogeographica, v. 69, n. 1, p. 15-45. 1993.

Alternative models of vertebrate speciation in Amazonia: an overview.

Biodiversity and Conservation, v. 6, n. 3, p. 451-476. 1997.

HALDANE, J. B. S. Sex ratio and unisexual sterility in hybrid animals. Journal of Genetics, v. 12, p. 101-109. 1922.

HALL, T. A. BioEdit: a user-friendly biological sequence alignment editor and analysis program for Windows 95/98/NT. Nucleic Acids Symposium Series, $v$. 41, p. 95-98. 1999.

HARING, E. The complete sequence of the mitochondrial genome of Buteo buteo (Aves, Accipitridae) indicates an early split in the phylogeny of raptors. Molecular Biology and Evolution, v. 18, n. 10, p. 1892-1904. 2001. 
HARRISON, C., WALKER, C. Birds of the British Upper Eocene. Zoological Journal of the Linnean Society, v. 59, p. 323-351. 1976.

HELBIG, A. J., KOCUM, A., SEIBOLD, I., BRAUN, M. J. A multi-gene phylogeny of aquiline eagles (Aves: Accipitriformes) reveals extensive paraphyly at the genus level. Molecular Phylogenetics and Evolution, v. 35, n. 1, p. 147-164. 2005.

HELLMAYR, C. E., CONOVER, B. Catalogue of birds of the Americas, vol. 13, pt. 1, n. 4. Chicago: Field Museum of Natural History. 1949. 358 p. (Zoological Series)

HOOGHIEMSTRA, H., VAN DER HAMMER, T. Neogene and Quartenary development of the neotropical rain forest: the forest refugia hypothesis, and a literature overview. Earth-Science Reviews, v. 44, n. 3-4, p. 147-183. 1998.

HOORN, C., GUERRERO, J., SARMIENTO, G. A., LORENTE, M. A. Andean tectonics as a cause for changing drainage patterns in Miocene northern South America. Geology, v. 23, n. 3, p. 237-240. 1995.

HOPKINS, D. Sea level history of Beringia during the past 250000 years. Quartenary Research, v. 3, p. 520-540. 1973.

HULL, J. M., SAVAGE, W. K., P, S. J., N, M., L, C., C, H. A., B, E. H. Hybridization among Buteos: Swainson's hawks (Buteo swainsoni) $x$ red-tailed hawks (Buteo jamaicensis). Wilson Journal of Ornithology, v. 119, n. 4, p. 579-584. 2007.

INFONATURA. Animals and ecosystems of Latin America. Disponível em: http://www.natureserve.org/infonatura. Acesso em: 10 de outubro de 2007

JOSEPH, L., WILKE, T., ALPERS, D. Independent evolution of migration on the South American landscape in a long-distance temperate-tropical migratory bird, Swainson`s Flycatcher (Myiarchus swainsoni). Journal of Biogeography, $v$. 30, p. 925-937. 2003.

KONDO, B., OMLAND, K. E. Ancestral state reconstruction of migration: multistate analysis reveals rapid changes in New World orioles (Icterus spp.). Auk, v. 124, n. 2, p. 410-419. 2007.

KRUCKENHAUSER, L., HARING, E., PINSKER, W., RIESING, M. J., WINKLER, H., WINK, M., GAMAUF, A. Genetic vs. morphological differentiation of Old World buzzards (genus Buteo, Accipitridae). Zoologica Scripta, v. 33, n. 3, p. 197-211. 2004.

KVIST, L., MARTENS, J., NAZARENKO, A. A., ORELL, M. Paternal leakage of mitochondrial DNA in the great tit (Parus major). Molecular Biology and Evolution, v. 20, n. 2, p. 243-247. 2003.

LERNER, H. R., KLAVER, M., MINDELL, D. P. Molecular phylogenetics of the Buteonine birds of prey (Aves, Accipitridae). The Auk. no prelo. 
LERNER, H. R., MINDELL, D. P. Phylogeny of eagles, Old World vultures, and other Accipitridae based on nuclear and mitochondrial DNA. Molecular Phylogenetics and Evolution, v. 37, n. 2, p. 327-346. 2005.

LOWE, T. M., EDDY, S. R. tRNAscan-SE: a program for improved detection of tranfer RNA genes in genomic sequences. Nucleic Acids Research, v. 25, p. 955-964. 1997.

LUNDBERG, J. G., MARSHALL, L. G., GUERRERO, J., HORTON, B., MALABARBA, M. C., WESSELINGH, F. The stage for Neotropical fish diversification: a history of tropical South American rivers. In: MALABARBA, L. R., REIS, R. E., VARIA, R. P., LUCENA, Z. M. e LUCENA, C. A. S. (org). Phylogeny and classification of Neotropical fishes. Porto Alegre: EDIPUCR, 1998. p. 13-48.

MADDISON, W. P., MADDISON, D. R. Mesquite: a modular system for evolutionary analysis. Disponível em: http://mesquiteproject.org. Acesso em: 07 de dezembro de 2007

MARINCOVICH JR, L., GLADENKOV, A. Y. Evidence for an early opening of the Bering Strait. Nature, v. 397, p. 149-151. 1999.

New evidence for the age of Bering Strait. Quartenary Science Reviews, v. 20, p. 329-335. 2001.

MARINI, M. A., HACKETT, S. J. A multifaceted approach to the characterization of an intergeneric hybrid manakin (Pipridae) from Brazil. Auk, v. 119, n. 4, p. 1114-1120. 2002.

MÉIO, B. B., FREITAS, C. V., JATOBÁ, L., SILVA, M. E. F., RIBEIRO, J. F., HENRIQUES, R. P. B. Influência da flora das florestas Amazônica e Atlântica na vegetação do cerrado sensu strictu. Revista Brasileira de Botânica, v. 26, n. 4, p. 437-444. 2003.

MIYAKI, C., MATIOLI, S. R., BURKE, T., WAJNTAL, A. Parrot evolution and paleogeographical events: mitochondrial DNA evidence. Molecular Biology and Evolution, v. 15, p. 544-551. 1998.

MONTGOMERY, D. R., BALCO, G., WILLET, S. D. Climate, tectonics and the morphology of the ANdes. Geology, v. 29, n. 7, p. 579-582. 2001.

MOORE, W. S. Inferring Phylogenies from mtDNA Variation: MitochondrialGene Trees Versus Nuclear-Gene Trees. Evolution, v. 49, n. 4, p. 718-726. 1995.

NORES, M. An alternative hypothesis for the origin of Amazonian bird diversity. Journal of Biogeography, v. 26, n. 3, p. 475-485. 1999.

NYÁRI, A. S. Phylogeographic patterns, molecular and vocal differentiation, and species limits in Schiffornis turdina (Aves). Molecular Phylogenetics and Evolution, v. 44, p. 154-164. 2006. 
OLIVO, C. Fall migration of the White-tailed Hawk in central Bolivia. Journal of Raptor Research, v. 37, p. 63-64. 2003.

OLSON, S. L. The fossil record of birds. In: FARNER, D. S., KING, J. R. e PARKES, K. C. (org). Avian biology. Orlando: Academic Press, 1985. vol.8 p. 80-238.

Fossil evidence os the Rufous Crab-Hawk (Buteogallus aequinoctialis) in Jamaica. Journal of Raptor Research, v. 40, n. 4, p. 284-287. 2006.

OUTLAW, D. C., VOELKER, G., MILA, B., GIRMAN, D. J. Evolution of long-distance migration in and historical biogeography of Catharus thrushes: a molecular phylogenetics approach. Auk, v. 120, n. 2, p. 299-310. 2003.

PAVEZ, E. Migratory movements of the White-throated Hawk (Buteo albigula) in Chile. Journal of Raptor Research, v. 34, p. 143-147. 2000.

PEREIRA, S., BAKER, A. J. Vicariant speciation of curassows (Aves, Cracidae): a hypothesis based on mitochondrial DNA phylogeny. Auk, v. 121, n. 3, p. 682694. 2004.

PEREIRA, S. L., JOHNSON, K. P., CLAYTON, D. H., BAKER, A. J. Mitochondrial and nuclear DNA sequences support a cretaceous origin of Columbiformes and a dispersal-driven radiation in the paleogene. Systematic Biology, v. 56, n. 4, p. 656-672. 2007.

PORZECANSKI, A. L., CRACRAFT, J. Cladistic analysis of distributions and endemism (CADE): using raw distributions of birds to unravel the biogeography of the South American aridlands. Journal of Biogeography, v. 32, n. 2, p. 261275. 2005.

POSADA, D., CRANDALL, K. A. MODELTEST: testing the model of DNA substitution. Bioinformatics, v. 14, n. 9, p. 817-818. 1998.

RASMUSSEN, D. T., OLSON, S. L., SIMONS, E. L. Fossil birds from the Oligocene Jebel Qatrani Formation, Fayum Province, Egypt. Smithsonian Contributions to Paleobiology, v. 62, p. 1-20. 1987.

REMSEN JR., J. V., JARAMILLO, A., NORES, M., PACHECO, J. F., ROBBINS, M. B., SCHULENBERG, T. S., STILES, F. G., SILVA, J. M. C., STOTZ, D. F., ZIMMER, K. J. A classification of the bird species of South America. American Ornithologists' Union.

http://www.museum.lsu.edu/ Remsen/SACCBaseline.html. Acesso em: 21 de dezembro de 2007

RIBAS, C. C., GABAN-LIMA, R., MIYAKI, C. Y., CRACRAFT, J. Historical biogeography and diversification within the Neotropical parrot genus Pionopsitta (Aves: Psittacidae). Journal of Biogeography, v. 32, n. 8, p. 14091427. 2005. 
RIBAS, C. C., JOSEPH, L., MIYAKI, C. Y. Molecular systematics and patterns of diversification in Pyrrhura (Psittacidae), with special reference to the pictaleucotis complex. Auk, v. 123, n. 3, p. 660-680. 2006.

RIBAS, C. C., MIYAKI, C. Y. Molecular systematics in Aratinga parakeets: species limits and historical biogeography in the 'solstitialis' group, and the systematic position of Nandayus nenday. Molecular Phylogenetics and Evolution, v. 30, n. 3, p. 663-675. 2004.

RIBAS, C. C., MOYLE, R. G., MIYAKI, C. Y., CRACRAFT, J. The assembly of montane biotas: linking Andean tectonics and climatic oscillations to independent regimes of diversification in Pionus parrots. Proceedings of the Royal Society B: Biological Sciences, v. 274, n. 1624, p. 2399-2408. 2007.

RIDGWAY, R. Studies of the American Falconidae. Bulletin of the U.S. Geological and Geographical Survey of the Territories, v. 2, p. 91-182. 1876.

RIESING, M. J., KRUCKENHAUSER, L., GAMAUF, A., HARING, E. Molecular phylogeny of the genus Buteo (Aves: Accipitridae) based on mitochondrial marker sequences. Molecular Phylogenetics and Evolution, v. 27, n. 2, p. 328342. 2003.

RIZZINI, C. T. Nota prévia sobre a divisão fitogeográfica do Brasil. Revista Brasileira de Geografia, v. 25, p. 1-64. 1963.

RONQUIST, F., HUELSENBECK, J. P. MrBayes 3: Bayesian phylogenetic inference under mixed models. Bioinformatics, v. 19, n. 12, p. 1572-1574. 2003.

ROSSETI, D., MANN DE TOLEDO, P., GÓES, A. M. New geological framework for Western Amazonia (Brazil) and implications for biogeography and evolution. Quartenary Research, v. 63, p. 78-89. 2005.

SHIMODAIRA, H., HASEGAWA, M. Multiple comparisions of log-likelihoods with applications to phylogenetic inference. Molecular Biology and Evolution, $v$. 16, p. $1114-1116.1999$.

SICK, H. Ornitologia Brasileira. Rio de Janeiro: Nova Fronteira. 1997. 912 p.

SORENSON, M. D., AST, J. C., DIMCHEFF, D. E., YURI, T., MINDELL, D. P. Primers for a PCR-based approach to mitochondrial genome sequencing in birds and vertebrates. Molecular Phylogenetics and Evolution, v. 12, n. 105-114. 1999.

STRESEMANN, E., AMADON, D. Order Falconiformes. In: MAYR, E. e COTTREL, G. W. (org). Check-list of birds of the world. Cambridge: Museum of Comparative Zoology, 1979. vol.1 p. 271-425.

SWOFFORD, D. L. PAUP*. Phylogenetic analysis using parsimony (*and Other Methods). Version 4. Massachusetts: Sinaver Associates. 2003. 
TAMURA, K., DUDLEY, J., NEl, M., KUMAR, S. MEGA4: Molecular Evolutionary Genetics Analysis (MEGA) software version 4.0. Molecular Biology and Evolution, v. 24, n. 8, p. 1596-1599. 2007.

THIOLLAY, J. M. Family Accipitridae (hawks and eagles). In: DEL HOYO, J. M. (org). Handbook of the birds of the world: New World vultures to guineafowl. Barcelona: Lynx Edicions, 1994. vol.2 p. 52-205.

THOMPSON, J. D., GIBSON, T. J., PLEWNIAK, F., JEANMOUGIN, F., HIGGINS, D. G. The CLUSTAL_X windows interface: flexible strategies for multiple sequence alignment aided by quality analysis tools. Nucleic Acids Research, v. 25, n. 24, p. 4876-4882. 1997.

THORNE, J., KISHINO, H. Multidivtime software. Disponível em: http://statgen.ncsu.edu/thorne/multidivtime.html. Acesso em: 15 de abril de 2007

THORUP, K., ALERSTAM, T., HAKE, M., KJELLÉN, K. Bird orientation: compensation for wind drift in migrating raptors is age dependent. Proceedings of the Royal Society B: Biological Sciences, v. 7, p. S1-S4. 2003.

VANZOLINI, P. E., WILLIAMS, E. E. The vanishing refuges: a mechanism for ecogeographic speciation. Papés Avulsos de Zoologia, São Paulo, v. 34, p. 251-255. 1981.

VOOUS, K., DE VRIES, T. Systematic place and geographic history of the Galapagos hawk, Buteo galapagoensis. Le Gerfaut, v. 68, p. 245-252. 1978.

WALLACE, A. R. On the monkeys of the Amazon. Proceedings of the Zoological Society of London, v. 20, p. 107-110. 1852.

WETMORE, A., CASE, E. C. A new fossil hawk from the Oligocene beds of South Dakota. Contributions from the Museum of Paleontology, University of Michigan, v. 4, n. 8, p. 129-132. 1934.

WOODROFFE, C. D., GRINDROD, J. Mangrove biogeography: the role of Quartenary environmental and sea-level change. Journal of Biogeography, $v$. 18, p. 479-492. 1991.

YANG, Z. PAML: A program package for phylogenetic analyses by maximum likelihood. Cabios Applications Note, v. 13, n. 5, p. 555-556. 1997.

ZINK, R. M. Towards a framework for understanding the evolution of avian migration. Journal of Avian Biology, v. 33, n. 4, p. 433-436. 2002.

ZWICKL, D. J. Genetic algorithm approaches for the phylogenetic analysis of large biological sequence datasets under the maximum likelihood criteria. Disponível em: www.bio.utexas.edu/faculty/antisense/garli/Garli.html. Acesso em: 20 de dezembro de 2007 
Capítulo 3

Um modelo de estrutura secundária do rRNA 165 de Aves baseado em análise comparativa 


\section{Introdução}

Os ácidos ribonucléicos (RNA) são de fundamental importância para o metabolismo celular, participando em diversas funções biológicas, como síntese protéica, transporte e armazenamento de informação genética (STRYER, 1996). O interesse por estas moléculas tem se renovado com descobertas recentes de novas funções regulatórias do RNA em bactérias e eucariotos (veja revisão em STORZ, 2002). Uma das características comuns à distintas famílias funcionais de RNA é a presença de uma complexa estrutura secundária (ES), que consiste em ligações adjacentes e antiparalelas entre as bases nucleotídicas, em sua maioria canônicas (ou também denominadas de Watson-Crick, i. e. A-U e G-C) e ligações G-U (BROWN \& ELLIS, 2005), e que são de vital importância para a execução das funções biológicas de moléculas de RNA (HUNTZINGER et al., 2005)

Padrões gerais de ES são altamente conservados, mesmo em casos de alta divergência entre seqüências (i.e. estrutura primária) (GUTELL et al., 1992). No entanto, devido à participação de apenas parte da molécula na ES, taxas de evolução distintas podem ser observadas entre diferentes porções da molécula. Entre eucariotos, a evolução é mais acelerada em regiões livres (alças) do que nas emparelhadas (hastes), padrão inverso ao encontrado em bactérias (SMIT et al., 2007). Esta heterogeneidade de taxas em um único marcador pode proporcionar informação útil para a inferência de divergências recentes e antigas ao longo da história evolutiva de um grupo de espécies, fato que levou à ampla utilização seqüências de DNA ribossômicos mitocondriais (12S e 16S) e nucleares (e. g. 18S) em estudos filogenéticos de grupos taxonômicos diversos (DIXON \& HILLIS, 1993). A sistemática molecular de aves, por exemplo, tem sido amplamente beneficiada pelo uso de seqüências de $12 \mathrm{~S}$ e $16 \mathrm{~S}$ (e.g. HOUDE et al., 1997; GARCÍA-MORENO et al., 2003; AMARAL et al., 2006; TAVARES et al., 2006; PEREIRA et al., 2007).

Embora a existência de ES em moléculas de RNA seja conhecida antes mesmo da utilização destas seqüências em estudos filogenéticos (e. g. DOTY et al., 1959), de forma geral informações sobre os sítios emparelhados envolvidos não são incorporadas em inferências evolutivas. Embora a utilidade da ES seja reconhecida no estabelecimento de hipóteses de 
homologia primária (KJER, 1995) e detecção de pseudogenes (SORENSON \& QUINN, 1998; mas veja opinião contrária em OLSON \& YODER, 2002), talvez o uso mais importante desta informação esteja na tentativa de corrigir potenciais efeitos negativos oriundos da covariação entre sítios das hastes. Os efeitos desta covariação permanecem pouco explorada na sistemática molecular de aves (DIXON \& HILLIS, 1993), principalmente no uso de métodos probabilísticos.

Apesar das seqüências de DNA ribossômico 125 e 165 serem os rRNA mais amplamente utilizados em estudos de aves, enquanto um modelo de ES já foi proposto para o rRNA $12 S$ de aves (ESPINOSA DE LOS MONTEROS, 2003), um modelo para o rRNA 165 ainda não está disponível. Aproveitando-se do grande número de seqüências completas do rRNA 165 publicadas, o objetivo do presente capítulo é propor um modelo de ES deste marcador para a classe Aves com base em análise comparativa de seqüências. A análise comparativa, baseada na identificação de substituições compensatórios em alinhamentos múltiplos, tem se mostrado uma estratégia eficiente para a predição de ES de rRNA, já que são freqüentemente corroborados por estudos de cristalográfia (GUTELL et al., 1992). 


\section{Material e Métodos}

Cento e dezoito seqüências completas do rRNA 16S, compreendendo pelo menos uma espécie de todas as ordens de aves atuais, assim como 3 espécies extintas (Dinornis giganteus, Emeus crassus, Anomalopteryx didiformis), foram obtidas do Genbank (Anexo N). A classificação e a seqüência taxonômica seguem del Hoyo (1992) com pequenas modificações: os abutres do Novo Mundo (Família Cathartidae) foram incluídos em uma ordem própria (Cathartiformes, como sugerido pelo Comitê Brasileiro de Registros Ornitológicos, 2007), enquanto os gêneros Dinornis, Emeus e Anomalopteryx foram incluídos na ordem Dinornithiformes. Dada a relação ainda incerta da família Cathartidae (veja capítulo 1), a ordem Cathartiformes foi tentativamente incluída antes da ordem Falconiformes na seqüência taxonômica utilizada.

O modelo de ES proposto para o 165 de mamíferos (BURK et al., 2002, ao qual refere-se a partir deste ponto apenas como "modelo de mamíferos"), que reconhece 53 hastes, serviu como base do modelo construído para aves. As seqüências foram inicialmente alinhadas utilizando o CLUSTAL W 1.81 (THOMPSON et al., 1997), e posteriormente manualmente ajustadas utilizando o programa Bioedit v.7.0 (HALL, 1999) para refletir a estrutura do modelo de mamíferos. As hastes foram identificadas por meio de comparação da seqüência primária e regiões franqueadoras entre os alinhamentos de aves e mamíferos. Hiatos foram preferencialmente inseridos nas alças em caso de ambigüidade. Em situações de baixa similaridade entre a seqüência primária dos alinhamentos de aves e mamíferos, o conjunto de dados da região em questão foi analisado com o programa MARNA (SIEBERT \& BACKOFEN, 2005) com parâmetros padrão, e o alinhamento e estrutura resultante então submetidos à busca por substituições compensatórias (substituições que ocorrem em dois sítios, em função da manutenção da estrutura). O programa MARNA simultaneamente alinha seqüências de RNA e infere a ES, O que diminui a subjetividade de alinhamentos múltiplos de regiões altamente divergentes. Estas seqüências parciais de regiões divergentes foram também submetidas a dobramento utilizando o programa RNAfold (HOFACKER et al., 
1994), como forma de auxiliar a identificação de sítios emparelhados de forma independente do MARNA.

A presença de uma haste ou posição da haste foi avaliada com base no critério de Springer e Douzery (1996), que sugeriram que emparelhamentos canônicos ou G-U devem ocorrer na maioria da espécies em pelo menos $75 \%$ das ordens analisadas. Foi considerada nesta análise "maioria" como $75 \%$ ou mais espécies emparelhadas; conseqüentemente exigiu-se emparelhamento de todas as seqüências de ordens representadas por três ou menos espécies. Cada haste foi considerada validada em caso de existência de substituições compensatórias, entre espécies de aves, ou em casos de seqüências invariantes dentro da classe Aves, entre aves e mamíferos. Substituições em apenas um dos sítios de um par correlacionado (e.g. G-U para G-C) não foram consideradas como substituição compensatória. Emparelhamentos não-canônicos foram permitidos nas posições 36-6 (A-C) e 51-9 (A-G), como inferido no modelo de mamíferos. Embora neste último modelo tenham sido também permitidos emparelhamentos não-canônicos nas posições 12-3 (A-C) e 15-8 (A-G), estes não foram aqui incorporados pois 1) A haste 12 em aves não apresenta tal emparelhamento na posição 3; e 2) a haste 15 foi inferida no presente modelo utilizando o programa MARNA, e a estrutura primária desta haste é altamente divergente da seqüências de mamíferos. Interações terciárias (e.g. pseudoknots) não foram incluídas no presente modelo. A haste 43 apresentada por Gutel et al. (1994) para Bos taurus não foi considerada no modelo de mamíferos por Burk, Springer e Douzery (2002) por não ter sido determinada com precisão na análise comparativa, e por razão similar não foi incluída no presente modelo.

A mesma numeração utilizada no modelo de mamíferos foi adotada para finalidade de comparação. A diagramação da estrutura foi realizada com o programa RnaViz2 (DE RIJK et al., 2003). Para lista completa de exemplos de substituição compensatória e alinhamento de espécies selecionadas com indicação das hastes, veja Anexo $O$ e Anexo $P$, respectivamente. 


\section{Resultados}

Foram identificadas 51 hastes (de 53 reconhecidas no modelo de mamíferos), das quais 42 são corroboradas por exemplos de covariação entre espécies de aves (38) ou entre aves e mamíferos (quatro) (Figuras 1 e 2). O tamanho da seqüência total do rRNA 16S de Aves variou entre 1572 e 1625, com o alinhamento totalizando 1827 posições. Deste total, 566 bases (o que corresponde a 283 pares de sítios) estiveram emparelhadas em mais de $75 \%$ das ordens. Sítios de hastes presentes no modelo de mamíferos foram na maioria dos casos prontamente identificados. Em alguns casos hastes completas ou posições de alinhamento não foram incluídas no modelo devido a emparelhamento ou alinhamento ambíguo. Cada uma das hastes foi discutida abaixo com relação ao modelo de mamíferos.

\section{Dimínio I (Hastes 1-4)}

\section{Haste 1}

A sequência primária desta haste em Aves foi idêntica à apresentada no modelo de mamíferos, portanto nenhuma evidência compensatória foi encontrada em Aves, ou entre aves e mamíferos.

\section{Haste 2}

A posição 2-1 pôde ser estruturada de forma alternativa em sítios distintos (concordando com o modelo de mamíferos), com uma potencial mudança de sítio na posição imediatamente 3' à posição 2-1'. O primeiro arranjo incluiu substituições compensatórias (e. g. Charadrius), mas bases desemparelhadas na maioria das ordens. Utilizando o arranjo alternativo existeu emparelhamento em todas as espécies, mas ausência de substituições compensatórias. Dada a subjetividade em determinar esta posição, esta não foi aqui incluída. O restante da haste foi sustentado por evidência compensatória na posição 2-3.

\section{Haste 3}

Nenhuma evidência compensatória foi encontrada em Aves, mas existiu evidência compensatória entre aves e mamíferos (posição 3-2). 


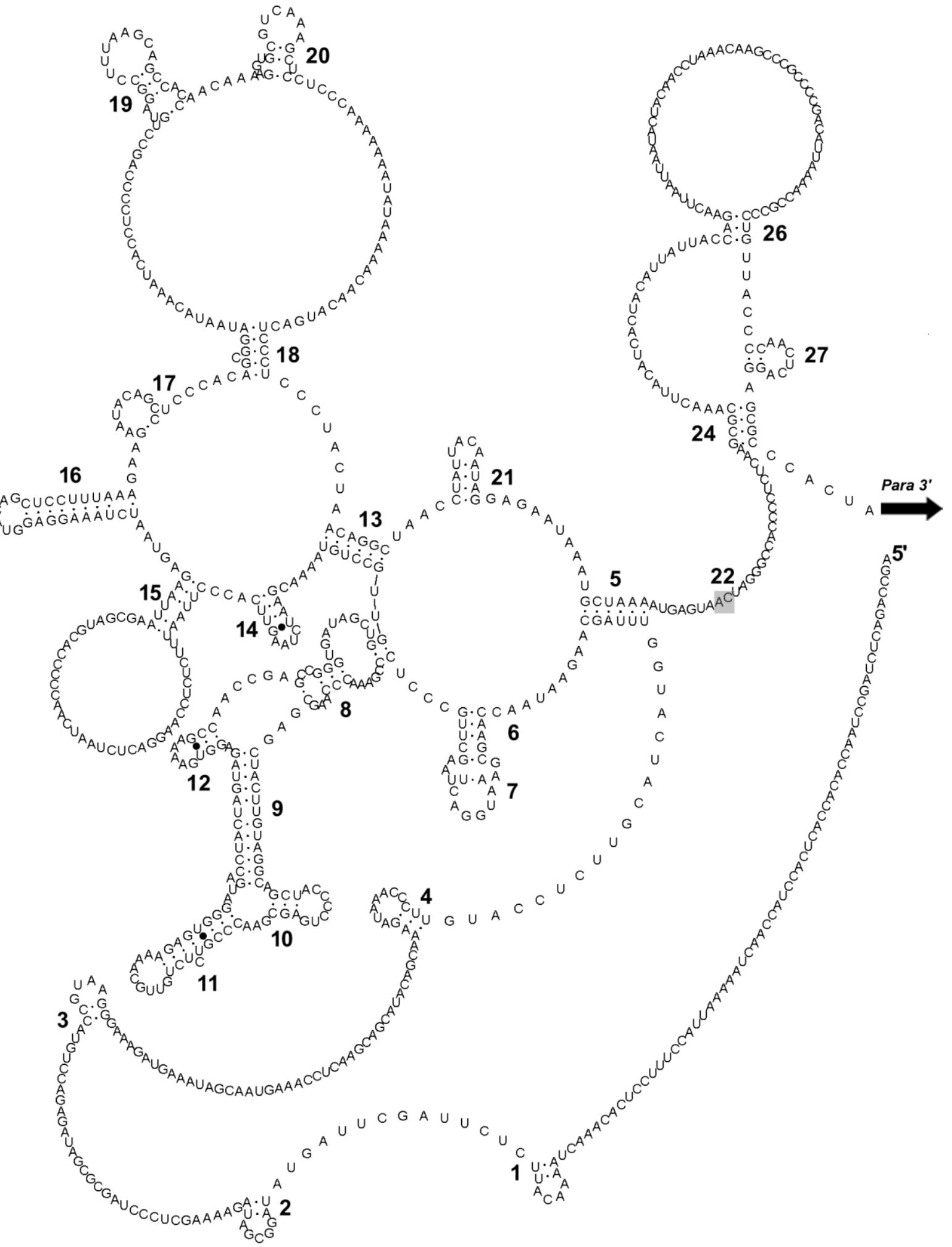

Figura 1. Primeira metade do modelo de estrutura secundária do rRNA 165 de Aves, ilustrado em Buteo buteo. Pontos pequenos entre as bases representam ligações canônicas, e círculos negros ligações G-U. As bases emparelhadas com os sítios indicados na haste 22 encontram-se na figura 2. 


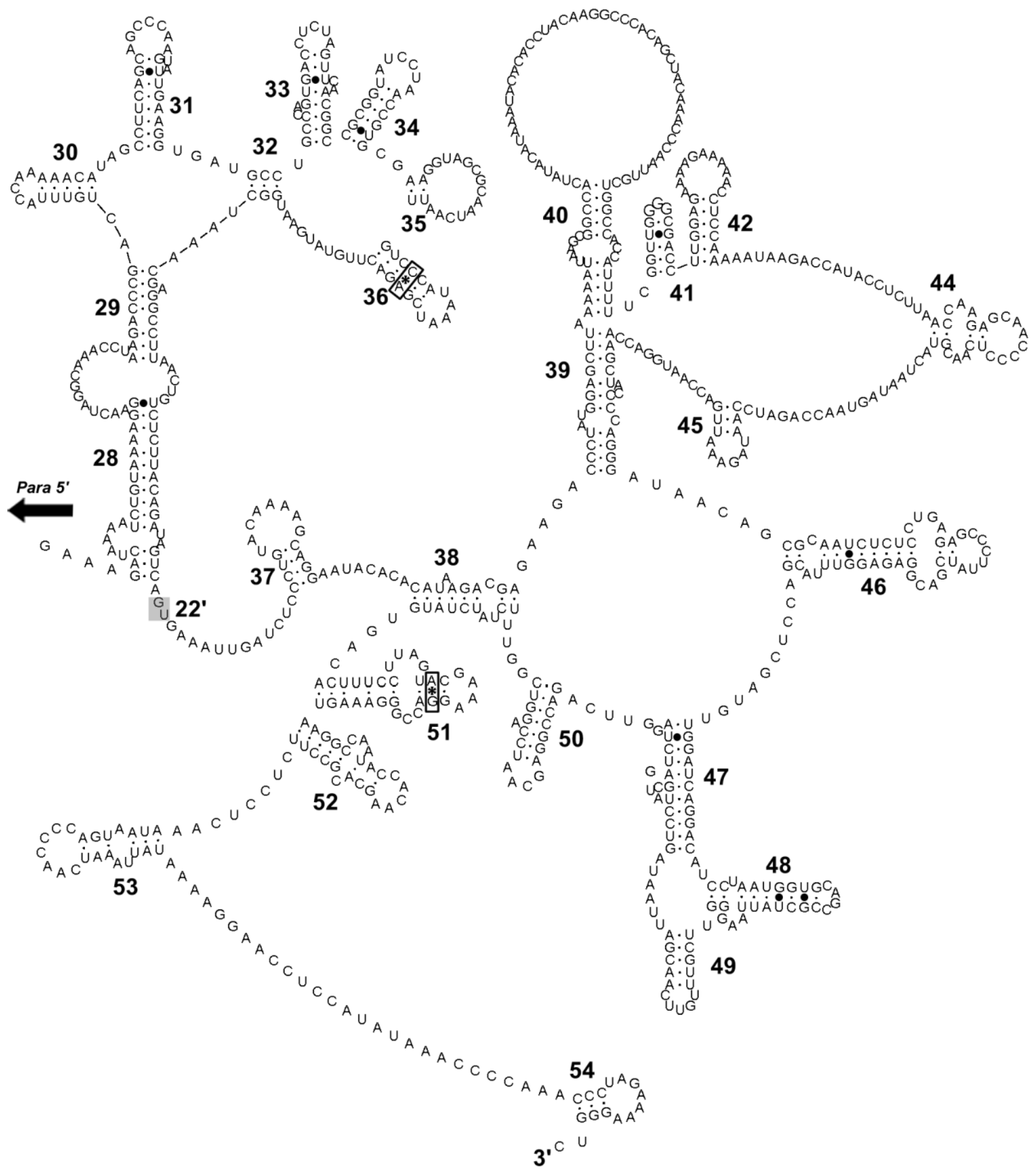

Figura 2. Segunda metade do modelo de estrutura secundária do rRNA 165 de Aves, ilustrado em Buteo buteo. Pontos pequenos entre as bases representam ligações canônicas, e círculos negros ligações G-U. Ligações indicadas por asteriscos e incluídas em retângulos indicam ligações não- canônicas consideradas no modelo. As bases emparelhadas com os sítios indicados na haste 22 encontram-se na figura 1. 


\section{Haste 4}

Nenhuma evidência compensatória foi encontrada em Aves, mas esta existiu evidência compensatória entre aves e mamíferos (posições 4-1 e 4-2).

\section{Domínio II (Hastes 5-21)}

\section{Haste 5}

A existência desta haste foi corroborada por múltiplas mudanças compensatórias em 5-2 e 5-3, assim como um exemplo de covariação em 56.

\section{Haste 6}

A posição 6-1 não foi incluída por não estar emparelhada na maioria das espécies. O restante desta haste foi corroborado por exemplos de substituição compensatória em 6-3 e 6-4. Uma posição potencial 6-5 (ausente no modelo de mamíferos) esteve emparelhada em todas as espécies, mas não foi incluída devido a ausência de evidência compensatória.

\section{Haste 7}

Esta haste foi corroborada por diversos exemplos de substituição compensatória na posição 7-3.

\section{Haste 8}

Extensa evidência compensatória nas posições 8-4, 8-5, 8-6 e 8-7 corroboraram a existência desta haste.

\section{Haste 9}

A posição 9-6 não foi incluída por estar desemparelhada na maioria das espécies. Evidência compensatória foi encontrada nas posições 9-5 e 9-7.

\section{Haste 10}

Esta haste foi corroborada por exemplos de substituição compensatória em todas as posições. 


\section{Haste 11}

Esta haste foi corroborada por evidência compensatória na posição $11-4$.

\section{Haste 12}

A seqüência primária nesta haste em Aves foi idêntica à apresentada no modelo de mamíferos, portanto nenhuma covariação foi encontrada em Aves ou entre aves e mamíferos.

\section{Haste 13}

Exemplos de substituição compensatória em todas as posições suportaram a existência desta haste.

\section{Haste 14}

Esta haste foi corroborada por evidência compensatória nas posições 14-2 e 14-3.

\section{Haste 15}

Esta haste em especial foi inferida utilizando o programa MARNA, já que a homologia primária entre seqüência de aves e mamíferos não pode ser estabelecida de forma confiável. Aplicando-se a regra de $75 \%$ de emparelhamento de bases, cinco posições foram incluídas, todas apresentando exemplos de substituição compensatória. Neste caso a numeração dos sítios não necessariamente correspondeu ao modelo de mamíferos.

\section{Haste 16}

Esta haste foi corroborada por substituição compensatória nas posições 16-1, 16-3, 16-4, 16-6 e 16-9.

\section{Haste 17}

Apesar de diversos exemplos de substituições compensatórias em 17-2, este sítio não foi considerado no modelo, já que à maioria das ordens 
apresentaram bases não emparelhadas. O sítio 17-1 é sustentado por um exemplo de covariação posicional.

\section{Haste 18}

As posições 18-1 e 18-2 não estiveram emparelhadas em aves, e portanto não foram incluídas. Múltipla evidência compensatória na posição 18-7.

\section{Haste 19}

O sítio 19-1 pôde ser emparelhado em diversos sítios vizinhos em relação ao proposto para mamíferos, e portanto não foi incluído. Nenhum exemplo de evidência compensatória pôde ser encontrado em aves ou entre aves e mamíferos.

\section{Haste 20}

Esta haste foi sustentada por covariação na posição 20-1.

\section{Haste 21}

A haste foi sustentada por substituições compensatórias nas posições 21-2 e 21-5. A posição 21-1 não faz parte do modelo, já que bases emparelhadas representaram menos de $25 \%$ das ordens, apesar da existência de evidência compensatória.

\section{Domain III (Hastes 22-27)}

\section{Haste 22}

Esta haste foi corroborada por evidência compensatória na posição $22-2$.

\section{Haste 23}

Não foi possível estabelecer homologia entre a região desta haste em mamíferos e a seqüência primária de aves. Por outro lado, nenhuma estrutura óbvia foi encontrada por meio dos programas MARNA e RNAfold. Por este motivo, esta haste não foi considerada no modelo. 


\section{Haste 24}

Esta haste foi sustentada por exemplos de substituição compensatória em todas as posições, exceto 24-2.

\section{Haste 25}

Pelo mesmo motivo da haste 23 esta haste não foi incluída no modelo de aves.

\section{Haste 26}

Existe evidência compensatória múltipla nas posições 26-2 e 26-3, que sustentam a existência desta haste.

\section{Haste 27}

A seqüência primária de todas as espécies foi idêntica às apresentadas no modelo de mamíferos, e portanto nenhuma evidência compensatória pôde ser encontrada.

\section{Domínio IV (Hastes 28-36)}

\section{Haste 28}

A existência desta haste foi sustentada por exemplos de substituição compensatória em todas as posições, exceto 28-1, 28-11, 28-12 e 28-13.

\section{Haste 29}

Esta haste foi sustentada por exemplos de substituição compensatória em todas as posições exceto 29-6, 29-7 e 29-8.

\section{Haste 30}

A seqüência primária de todas as espécies foi idêntica às apresentadas no modelo de mamíferos, e portanto nenhuma evidência compensatória pode ser encontrada. 


\section{Haste 31}

Evidência compensatória nos sítios 31-3, 31-4 e 31-5 corroboraram a existência desta haste.

\section{Haste 32}

A seqüência primária de todas as espécies é idêntica às apresentadas no modelo de mamíferos, e portanto nenhuma evidência compensatória pôde ser encontrada.

\section{Haste 33}

Esta haste foi sustentada por exemplos de covariação na posição 33-8.

\section{Haste 34}

Existiu evidência compensatória na posição 34-4.

\section{Haste 35}

A posição 35-3 não pôde ser emparelhada na maioria das espécies de aves, e portanto não foi aqui considerada. As duas posições restantes não apresentam exemplos de covariação em aves ou entre aves e mamíferos.

\section{Haste 36}

Apesar de substituição compensatória na posição 36-4, esta haste não foi incluída por não estar emparelhada na maioria das espécies. Apesar da maioria das ligações na posição 36-6 serem não canônicas (A-C), estas foram permitidas devido à evidência a favor da existência destas ligações em grupos diversos.

\section{Haste 37}

Esta haste foi corroborada por exemplos de covariação em todas as posições.

\section{Domínio V (Hastes 38-50)}




\section{Haste 38}

Evidência compensatória na posição 38-3 sustentaram a existência desta haste.

\section{Haste 39}

Apesar de existência de covariação na posição 39-9, esta não esteve emparelhada na maioria das espécies, e portanto não foi incluída. Embora todas as posições restantes sejam invariáveis em Aves, existe evidência compensatória entre aves e mamíferos.

\section{Haste $\mathbf{4 0}$}

As posições 40-6 to 40-8 não foram incluídas devido à dificuldades no alinhamento em algumas espécies, e falta de emparelhamento na maioria das espécies. Existe evidência compensatória em 40-3, 40-5, 40-9, 40-10, 40-11 e 40-12.

\section{Haste 41}

Esta haste foi corroborada por exemplos de covariação na posição 413.

\section{Haste 42}

Esta haste foi corroborada por exemplos de covariação na posição 421.

\section{Haste 44}

Apesar de existência de covariação na posição 44-5, esta não foi considerada pela falta de emparelhamento na maioria das espécies. Esta haste foi corroborada pela existência de substituição compensatória em 44-2 e 44-4.

\section{Haste 45}

Esta haste foi corroborada por covariação posicional na posição 45-3.

\section{Haste 46}


A posição 46-11 não foi aqui considerada pois a maioria das espécies apresentarem bases desemparelhadas. Existe evidência compensatória em 46-7, 46-8, 46-9 e 46-10.

\section{Haste 47}

Embora não exista evidência compensatória em Aves nesta haste, esta foi corroborada por covariação entre aves e mamíferos (posições 47-8 e 4711).

\section{Haste 48}

Esta haste foi corroborada por exemplos de covariação nas posições 48-3, 48-4 e 48-5.

\section{Hastes 49 e 50}

A seqüência primária de todas as espécies foi idêntica à apresentada no modelo de mamíferos, e portanto nenhuma evidência compensatória pôde ser encontrada.

\section{Domínio VI (Hastes 51-54)}

\section{Haste 51}

As posições 51-4 e 51-6 não foram aqui consideradas pelo alto número de espécies com bases desemparelhadas lapesar de existência de covariação). Emparelhamentos não-canônicos A-G foram permitidos (GUTELL et al., 1994; BURK et al., 2002). Esta haste foi sustentada por exemplos de covariação em todas as posições exceto 51-8, 51-9 e 51-10.

\section{Haste 52}

Apesar de exemplos de substituição compensatória, a posição 52-7 não foi considerada por estar desemparelhada na maioria das espécies. A existência desta haste é corroborada por evidência compensatória em todos os sítios exceto 52-3. 


\section{Haste 53}

Esta haste foi sustentada por exemplos de substituição compensatória em todos os sítios exceto 53-5 e 53-7. As posições 53-4 e 53-6 não foram incluídas pelo alto número de seqüências que não apresentaram emparelhamento.

\section{Haste 54}

Apesar de covariação posicional, a posição 54-1 não foi considerada devido ao alto número de espécies desemparelhadas. Embora o sítio imediatamente 3'à posição represente uma posição de emparelhamento potencial, neste caso não existiu evidência compensatória. Exemplos de substituição compensatória puderam ser encontrados em todas as posições restantes. 


\section{Discussão}

O modelo de estrutura secundária aqui proposto para o 165 de Aves incorpora 51 das 53 hastes propostas para mamíferos, sendo a grande maioria (48) suportada por pelo menos um exemplo de substituição compensatória. A identificação desta grande proporção de hastes corroboradas por evidência compensatória pode ser atribuída à ampla cobertura taxonômica utilizada, o que permitiu a identificação de substituições em alguns casos presentes apenas em poucas linhagens de aves (Anexo O). Enquanto a maioria das hastes propostas para o modelo de mamíferos foi identificada com facilidade em aves, com casos de seqüência primária idêntica entre espécies destes dois grupos, muitas regiões de alças não puderam ser alinhadas de forma confiável, mesmo entre ordens de Aves (veja alinhamento, Anexo P). Esta observação demonstra a heterogeneidade de taxas típico de rRNAs, assim como o padrão bem documentado entre eucariotos da evolução mais rápida das alças do que nas hastes (SMIT et al., 2007).

A proporção de mais de um terço de sítios emparelhados inferidos ressalta a necessidade de avaliação do impacto dos sítios dependentes em análises filogenéticas considerando o 16S. A ausência de dados de ES em análises filogenéticas viola a premissa de independência de sítios, que é um princípio comum a todos os critérios de otimização (DIXON \& HILLIS, 1993). Esta dependência de sítios pode gerar, em casos extremos, artefatos analíticos como erros na determinação das relações filogenéticas, ou superestimativa de valores de suporte nodal, já que substituições que ocorreram de forma dependente são consideradas duas vezes na análise, como eventos independentes. Por outro lado, este mesmo problema pode também levar a superestimativas de tamanho de ramo, o que pode levar a erros em inferências de tempo de divergência e reconstruções de estado ancestral baseadas em métodos probabilísticos. O desenvolvimento e implementação de modelos de evolução que incorporam dados de ES (i. e. doublet models) abriram uma nova era nas inferência filogenéticas de seqüências de RNA (LEWIS, 2001), permitindo um tratamento adequado das hastes em análises de máxima versossimilhança e análises bayesianas. 
É interessante notar, no entanto, que os poucos estudos filogenéticos que incorporaram este tipo de informação, utilizando modelos probabilísticos, detectaram poucas mudanças em relação às topologia obtidas em análises tradicionais (e.g. capítulo 2), mesmo em alguns casos de divergências profundas (TELLFORD et al., 2005). É possível que as taxas de evolução mais lentas das hastes, em especial em casos de baixa divergência, não sejam suficientes para afetar topologias e medidas de suporte nodal de forma significativa. Novas análises em níveis taxonômicos distintos são necessárias para confirmar estas observações, utilizando conjuntos de dados diversos.

A disponibilização do modelo aqui proposto para o 165 , junto ao modelo já disponível para o 125 (ESPINOSA DE LOS MONTEROS, 2003), e estes aliados à modelos evolutivos que possibilitam a incorporação de dados de dependência de sítios (e. g. MrBayes, PHASE) abrem a possibilidade para novas avaliações do efeito da estrutura secundária de seqüências de DNA ribossômicos em estudos filogenéticos de Aves, além de possibilitar inferências mais precisas utilizando estes marcadores. 


\section{Referências bibliográficas}

AMARAL, F. S. R., MILLER, M. J., SILVEIRA, L. F., BERMINGHAM, E., WAJNTAL, A. Polyphyly of the hawk genera Leucopternis and Buteogallus (Aves, Accipitridae): multiple habitat shifts during the Neotropical buteonine diversification. BMC Evolutionary Biology, v. 6, p. 10. 2006.

BROWN, J. W., ELLIS, J. C. Comparative analysis of RNA secondary structure: the 6S RNA. In: HARTMANN, R. K., BINDEREIF, A., SCHÖN, A. e WESTHOF, E. (org). Handbook of RNA biochemistry. Weinheim: Wiley-VCH 2005. p. 491-512.

BURK, A., DOUZERY, E. J. P., SPRINGER, M. S. The secondary structure of mammalian mitochondrial 16S rRNA molecules: refinements based on a comparative phylogenetic approach. Journal of Mammalian Evolution, v. 9, n. 3, p. 225-252. 2002.

COMITÊ BRASILEIRO DE REGISTROS ORNITOLÓGICOS. Listas das aves do Brasil. Disponível em: http://www.cbro.org.br. Acesso em: 16 de agosto de 2007

DE RIJK, P., WUYTS, J., DE WACHTER, R. RnaViz 2: an improved representation of RNA secondary structure. Bioinformatics, v. 19, n. 2, p. 299-300. 2003.

DEL HOYO, J., ELLIOTT, A., SARGATAL, J., COLLAR, N. J. Handbook of the birds of the world. Barcelona: Lynx Edicions. 1992. $1 \mathrm{~V}$.

DIXON, M. T., HILLIS, D. M. Ribosomal RNA secondary structure: compensatory mutations and implications for phylogenetic analysis. Molecular Biology and Evolution, v. 10, n. 1, p. 256-267. 1993.

DOTY, P., BOEDTKER, H., FRESCO, J. R., HASELKORN, R., LITT, M. Secondary Structure in Ribonucleic Acids. Proceedings of the National Academy of Sciences, v. 45, n. 4, p. 482-499. 1959.

ESPINOSA DE LOS MONTEROS, A. Models of the primary and secondary structure for the 12S rRNA of birds: a guideline for sequence alignment. DNA Sequence, v. 14, n. 4, p. 241-256. 2003.

GARCÍA-MORENO, J., SORENSON, M. D., MINDELL, D. P. Congruent avian phylogenies inferred from mitochondrial and nuclear DNA sequences. Journal of Molecular Evolution, v. 57, n. 1, p. 27-37. 2003.

GUTELL, R. R., LARSEN, N., WOESE, C. R. Lessons from an evolving rRNA: $16 S$ and 23S rRNA structures from a comparative perspective. Microbiological Reviews, v. 58, n. 1, p. 10-26. 1994.

GUTELL, R. R., POWER, A., HERTZ, G. Z., PUTZ, E. J., STORMO, G. D. Identifying constraints on the higer-order structure of RNA: continued development and application of comparative sequence analysis methods. Nucleic Acids Research, v. 20, n. 21, p. 5785-5795. 1992. 
HALL, T. A. BioEdit: a user-friendly biological sequence alignment editor and analysis program for Windows 95/98/NT. Nucleic Acids Symposium Series, $v$. 41, p. 95-98. 1999.

HOFACKER, I. L., FONTANA, W., STADLER, P. F., BONHOEFFER, L. S., TACKER, M., SCHUSTER, P. Fast folding and comparison of RNA secondary structures. Monatshefte fur Chemie, v. 125, p. 167-188. 1994.

HOUDE, P., A, C., E, L., E, S. A., MONTANO, G. A. Phylogeny and evolution of $12 S$ rDNA in Gruiformes (Aves). In: MINDELL, D. P. (org). Avian Molecular Evolution and Systematics., San Diego: Academic Press, 1997. p. 121-158.

HUNTZINGER, E., POSSEDKO, M., WINTER, F., MOINE, H., EHRESMANN, C., ROMBY, P. Probing RNA structures with enzymes and chemicals in vitro and in vivo. In: HARTMANN, R. K., BINDEREIF, A., SCHÖN, A. e WESTHOF, E. (org). Handbook of RNA biochemistry. Weinheim: Wiley-VCH 2005. p. 151-171.

KJER, K. M. Use of rRNA secondary structure in phylogenetic studies to identify homologous positions: an example of alignment and data presentation from the frogs. Molecular Phylogenetics and Evolution, v. 4, n. 3, p. 314-330. 1995.

LEWIS, P. Phylogenetic systematics turns over a new leaf. Trends in Ecology and Evolution, v. 16, n. 1, p. 30-37. 2001.

OLSON, L. E., YODER, A. D. Using secondary structure to identify ribosomal numts: cautionary examples from the human genome. Molecular Biology and Evolution, v. 19, n. 1, p. 93-100. 2002.

PEREIRA, S. L., JOHNSON, K. P., CLAYTON, D. H., BAKER, A. J. Mitochondrial and nuclear DNA sequences support a cretaceous origin of Columbiformes and a dispersal-driven radiation in the paleogene. Systematic Biology, v. 56, n. 4, p. 656-672. 2007.

SIEBERT, S., BACKOFEN, R. MARNA: multiple alignment and consensus structure prediction of RNAs based on sequence structure comparisons. Bioinformatics, v. 21, n. 16, p. 3352-3359. 2005.

SMIT, S., WIDMANN, J., KNIGHT, R. Evolutionary rates vary among rRNA structural elements. Nucleic Acids Research, v. 35, n. 10, p. 3339-3354. 2007.

SORENSON, M. D., QUINN, T. W. Numts: A challenge for avian systematics and population biology. Auk, v. 115, n. 1, p. 214-221. 1998.

SPRINGER, M. S., DOUZERY, E. Secondary structure and patterns of evolution among mammalian mitochondrial 12S rRNA molecules. Journal of Molecular Evolution, v. 43, n. 4, p. 357-373. 1996.

STORZ, G. An expanding universe of noncoding RNAs. Science, v. 296, n. 5571, p. 1260-1263. 2002.

STRYER, L. Bioquímica. 4 ed. Rio de Janeiro: Guanabara Koogan. 1996. 1000 p. 
TAVARES, E. S., BAKER, A. J., PEREIRA, S. L., MIYAKI, C. Y. Phylogenetic relationships and historical biogeography of neotropical parrots (Psittaciformes: Psittacidae: Arini) inferred from mitochondrial and nuclear DNA sequences. Systematic Biology, v. 55, n. 3, p. 454-470. 2006.

TELLFORD, M. J., WISE, M. J., GOWRI-SHANKAR, V. Consideration of RNA secondary structure significantly improves likelihood-based estimates of phylogeny: examples from the Bilateria. Molecular Biology and Evolution, v. 22, n. 4, p. $1129-1136.2005$.

THOMPSON, J. D., GIBSON, T. J., PLEWNIAK, F., JEANMOUGIN, F., HIGGINS, D. G. The CLUSTAL_X windows interface: flexible strategies for multiple sequence alignment aided by quality analysis tools. Nucleic Acids Research, v. 25, n. 24, p. 4876-4882. 1997. 
Capítulo 4

Conclusões 
- A filogenia inferida com base no conjunto combinado representa a hipótese mais resolvida das relações entre espécies de gaviões buteoninos até o momento. Estes resultados não suportam o monofiletismo dos gêneros Buteo, Leucopternis e Buteogallus.

- Embora as hipóteses filogenéticas derivadas de partições mitocondriais e do FIB5 separados tenham sido congruentes entre si, houve conflito significativo destes dados com topologias oriundas do LDH. Este conflito é provavelmente resultado de retenção de alelos ancestrais, devido ao tempo de coalescência mais longo de genes nucleares se comparados aos genes mitocondriais, longo tempo de geração, populações grandes e entrenós curtos na filogenia.

- A utilização de dados de sítios emparelhados de seqüências de RNA incluídas nas análises não trouxe mudanças significativas para as topologias e as inferências de tempo de divergência, provavelmente devido ao baixo grau de divergência das hastes.

- Os dados sugerem que diversificação dos gaviões buteoninos se deu inicialmente na região Neotropical, com posterior colonização e diversificação na região Neártica e no Velho Mundo. Das cinco linhagens principais obtidas, as espécies predominantemente neárticas e do Velho Mundo se concentraram na porção mais derivada da topologia, enquanto as espécies neotropicais formam a base da topologia. A diversificação do grupo pode ter iniciado no Oligoceno ou Mioceno, com eventos de especiação ocorrendo até o Pleistoceno.

- O comportamento migratório evolui diversas vezes entre os gaviões buteoninos, embora exista uma linhagem quase completamente migratória onde o comportamento surgiu uma ou poucas vezes. A evolução do comportamento migratório pode ter contribuído para a diversificação do grupo por 1) permitir a colonização de regiões temperadas na América do Norte e no Velho Mundo, e 2) promover especiação por meio de isolamento de populações migratórias desviadas de suas rotas. Este último mecanismo pode ter sido responsável pela especiação nas ilhas de Galápagos, Havaí e República Dominicana.

- Quatro disjunções trans/cis andinas ocorreram durante a diversificação do grupo e, de acordo com as estimativas de tempo de divergência, as duas mais antigas são provavelmente relacionadas à orogênese dos Andes. As outras duas disjunções podem ter sido causadas pela orogênese dos Andes, formação de refúgio florestais ou eventos de dispersão. A existência de dois pares de separações ocorrendo em períodos distintos sugerem possíveis eventos vicariantes periódicos.

- As linhagens neotropicais de gaviões buteoninos que ocupam habitats alagados pertencem à duas linhagens distintas, que evoluíram de forma independente de outras linhagens que ocupam outros habitats. A diversificação de uma destas linhagens pode ter sido resultado do desenvolvimento da bacia Amazônica, e posteriormente flutações do nível 
do mar. A única espécie de acipitrídeo neotropical especializada em manguezais é relacionada a uma outra espécie costeira de hábitos mais generalista, e estas duas à uma espécie de floresta de várzea da Amazônia, o que sugere uma relação histórica entre estes habitats.

- A diversificação recente de Leucopternis kuhli e Leucopternis melanops não necessariamente é resultado do efeito do Rio Amazonas como barreira, e pode ter sido fruto de Refúgios Florestais, conformação distinta do Amazonas em uma época de nível mais elevado do nível do mar, ou uma combinação dos dois processos.

- Espécies de áreas florestais e abertas não são reciprocamente monofiléticas, o que indica uma história dinâmica de diversificação destes habitats. De forma similar, espécies que ocupam a Mata Atlântica, Amazônia e florestas de baixada trans-andinas não são diretamente relacionadas, o que implica múltiplas conexões entre estas áreas no passado.

- Como forma de alinhar a nomenclatura dos gaviões buteoninos a grupos monofiléticos, são propostas diversas modificações, como a utilização dos gêneros Pseudastur, Percnohierax, Morphnarchus, Rupornis, assim como reorganização dos gêneros utilizados atualmente.

- O modelo de estrututa secundária proposto para o rRNA 165 de aves é composto por 51 hastes, das quais 42 são sustentados por exemplos de substituição compensatória em aves ou entre aves e mamíferos. A disponibilização deste modelo será útil para novas análises que procurem avaliar o efeito da dependência de sítios em inferência filogenéticas de aves utilizando este marcador. 


\section{Anexos}


Anexo A. Lista de amostras utilizadas no presente trabalho. Os seguintes acrônimos representam as instituição de origem: LGEMA, Laboratório de Genética e Evolução Molecular de Aves, USP, Brasil; LSUMZ, Louisiana State University Museum of Natural Science, EUA; ANSP, Academy of Natural Science of Philadelphia, EUA; MNHV, Museum of Natural History of Vienna, Austria. N/D representa "não disponível". Asteriscos na coluna "12S,tRNAVal,16S" representam amostras dais quais foram obtidas apenas sequência do marcador 12S. "Pend." representa número pendente. A legenda da coluna "Material" representa: "T", tecido de músculo ou víscera; "S", Sangue; "TP", Toe pads; "P", penas; "P/S", penas e sangue.

\begin{tabular}{|c|c|c|c|c|c|c|c|c|c|c|c|}
\hline Espécie & Amostra & Localidade & Material & Testemunho & $12 S$, Val, $16 \mathrm{~S}$ & ATP8/6 & ND6 & CytB & ND2 & LDH & FIB5 \\
\hline \multicolumn{12}{|l|}{ Novo Mundo } \\
\hline Busarellus nigricollis & LGEMA F1 19 & Roraima, Brasil & $\mathrm{T}$ & Espécime & $\sqrt{ }$ & $\sqrt{ }$ & $\sqrt{ }$ & $\sqrt{ }$ & $\sqrt{ }$ & $\sqrt{ }$ & $\sqrt{ }$ \\
\hline Buteo albicaudatus & LSUMZ 48298 & Guiana & $\mathrm{T}$ & Espécime & $\sqrt{ }$ & $\sqrt{ }$ & $\sqrt{ }$ & $\sqrt{ }$ & $\sqrt{ }$ & $\sqrt{ }$ & $\sqrt{ }$ \\
\hline Buteo albicaudatus & LGEMA F85 & Uruçuí-Una, PI, Brasil & $\mathrm{T}$ & Espécime & $\sqrt{ }$ & $\sqrt{ }$ & $\sqrt{ }$ & $\sqrt{ }$ & $\sqrt{ }$ & $\sqrt{ }$ & $\sqrt{ }$ \\
\hline Buteo albigula & LSUMZ 31984 & Cajamarca, Perú & $T$ & Espécime & $\sqrt{ }$ & $\sqrt{ }$ & $\sqrt{ }$ & $\sqrt{ }$ & $\sqrt{ }$ & $\sqrt{ }$ & $\sqrt{ }$ \\
\hline Buteo albonotatus & LSUMZ 28410 & Panamá & $\mathrm{T}$ & Espécime & $\sqrt{ }$ & $\sqrt{ }$ & $\sqrt{ }$ & $\sqrt{ }$ & $\sqrt{ }$ & $\sqrt{ }$ & $\sqrt{ }$ \\
\hline Buteo albonotatus & LGEMA F142 & Serra das Confusões, Pl, Brasil & $\mathrm{T}$ & Espécime & $\sqrt{ }$ & $\sqrt{ }$ & $\sqrt{ }$ & $\sqrt{ }$ & $\sqrt{ }$ & $\sqrt{ }$ & $\sqrt{ }$ \\
\hline Buteo brachyurus & ANSP 1691 & Zamora, Equador & $\mathrm{T}$ & Espécime & $\sqrt{ }$ & $\sqrt{ }$ & $\sqrt{ }$ & $\sqrt{ }$ & $\sqrt{ }$ & $N / D$ & $N / D$ \\
\hline Buteo brachyurus & LGEMA 11201 & Baixada Santista, SP, Brasil & PS & Fotografia & $\sqrt{ }$ & $\sqrt{ }$ & $\sqrt{ }$ & $\sqrt{ }$ & $\sqrt{ }$ & $\sqrt{ }$ & $\sqrt{ }$ \\
\hline Buteo galapagoensis & LGEMA F121 & Galápagos & $S$ & $N / D$ & $\sqrt{ }$ & $\sqrt{ }$ & $\sqrt{ }$ & $\sqrt{ }$ & $\sqrt{ }$ & $\sqrt{ }$ & $\sqrt{ }$ \\
\hline Buteo galapagoensis & LGEMA F122 & Galápagos & $S$ & $N / D$ & $\sqrt{ }$ & $\sqrt{ }$ & $\sqrt{ }$ & N/D & $\sqrt{ }$ & $\sqrt{ }$ & $\sqrt{ }$ \\
\hline Buteo jamaicensis fuertesi & LSUMZ 23616 & Novo México, EUA & $\mathrm{T}$ & Espécime & $\sqrt{ }$ & $\sqrt{ }$ & $\sqrt{ }$ & $\sqrt{ }$ & $\sqrt{ }$ & $\sqrt{ }$ & $\sqrt{ }$ \\
\hline Buteo jamaicensis umbrinus & LSUMZ 48897 & Bahamas & $\mathrm{T}$ & Espécime & $\sqrt{ }$ & $\sqrt{ }$ & $\sqrt{ }$ & $\sqrt{ }$ & $\sqrt{ }$ & $\sqrt{ }$ & $\sqrt{ }$ \\
\hline Buteo lagopus & LSUMZ 45908 & Idaho, EUA & $\mathrm{T}$ & Espécime & $\sqrt{ }$ & $\sqrt{ }$ & $\sqrt{ }$ & $\sqrt{ }$ & $\sqrt{ }$ & $\sqrt{ }$ & $\sqrt{ }$ \\
\hline Buteo lagopus & LSUMZ 8683 & Arizona, EUA & $\mathrm{T}$ & Espécime & $\sqrt{ }$ & $\sqrt{ }$ & $\sqrt{ }$ & $\sqrt{ }$ & $\sqrt{ }$ & $\sqrt{ }$ & $\sqrt{ }$ \\
\hline Buteo leucorrhous & LGEMA F103 & Santa Catarina, Brasil & $P$ & Fotografia & $\sqrt{*}$ & $\sqrt{ }$ & $\sqrt{ }$ & N/D & N/D & $N / D$ & $N / D$ \\
\hline Buteo leucorrhous & LSUMZ 33002 & Cajamarca, Perú & $\mathrm{T}$ & Espécime & $\sqrt{ }$ & $\sqrt{ }$ & $\sqrt{ }$ & $\sqrt{ }$ & $\sqrt{ }$ & $\sqrt{ }$ & $\sqrt{ }$ \\
\hline Buteo leucorrhous & ANSP 660 & Carchi, Equador & $\mathrm{T}$ & Espécime & $\sqrt{ }$ & $\sqrt{ }$ & $\sqrt{ }$ & $\sqrt{ }$ & $\sqrt{ }$ & $N / D$ & $N / D$ \\
\hline Buteo leucorrhous & ANSP 5082 & Napo, Equador & $\mathrm{T}$ & Espécime & $\sqrt{ }$ & $\sqrt{ }$ & $\sqrt{ }$ & $\sqrt{ }$ & $\sqrt{ }$ & $\mathrm{N} / \mathrm{D}$ & $N / D$ \\
\hline Buteo lineatus & LSUMZ 13596 & California, EUA & $\mathrm{T}$ & Espécime & $\sqrt{ }$ & $\sqrt{ }$ & $\sqrt{ }$ & $\sqrt{ }$ & $\sqrt{ }$ & $\sqrt{ }$ & $\sqrt{ }$ \\
\hline Buteo lineatus & LSUMZ 33263 & Loiusiana, EUA & $\mathrm{T}$ & Espécime & $\sqrt{ }$ & $\sqrt{ }$ & $\sqrt{ }$ & $\sqrt{ }$ & $\sqrt{ }$ & $N / D$ & $\sqrt{ }$ \\
\hline Buteo magnirostris & LSUMZ 42274 & Perú & $\mathrm{T}$ & Espécime & $\sqrt{ }$ & $\sqrt{ }$ & $\sqrt{ }$ & $\sqrt{ }$ & $\sqrt{ }$ & $\sqrt{ }$ & $\sqrt{ }$ \\
\hline Buteo magnirostris & LGEMA F74 & São Paulo, Brasil & $\mathrm{T}$ & Espécime & $\sqrt{ }$ & $\sqrt{ }$ & $\sqrt{ }$ & $\sqrt{ }$ & $\sqrt{ }$ & $\sqrt{ }$ & $\sqrt{ }$ \\
\hline
\end{tabular}


Continuação do Anexo A

\begin{tabular}{|c|c|c|c|c|c|c|c|c|c|c|c|}
\hline Espécie & Amostra & Localidade & Material & Testemunho & $12 S$, Val, $16 \mathrm{~S}$ & ATP8/6 & ND6 & CytB & ND2 & LDH & FIB5 \\
\hline Buteo nitidus & LSUMZ 9624 & Pando, Bolívia & $\mathrm{T}$ & Espécime & $\sqrt{ }$ & $\sqrt{ }$ & $\sqrt{ }$ & $\sqrt{ }$ & $\sqrt{ }$ & $\sqrt{ }$ & $\sqrt{ }$ \\
\hline Buteo nitidus & LSUMZ 8817 & Pando, Bolívia & $\mathrm{T}$ & Espécime & $\sqrt{ }$ & $\sqrt{ }$ & $\sqrt{ }$ & $\sqrt{ }$ & $\sqrt{ }$ & $\sqrt{ }$ & $\sqrt{ }$ \\
\hline Buteo platypterus & LSUMZ 48900 & Florida, EUA & $T$ & Espécime & $\sqrt{ }$ & $\sqrt{ }$ & $\sqrt{ }$ & $\sqrt{ }$ & $\sqrt{ }$ & $\sqrt{ }$ & $\sqrt{ }$ \\
\hline Buteo platypterus & LSUMZ 41224 & Louisiana, EUA & $T$ & Espécime & $\sqrt{ }$ & $\sqrt{ }$ & $\sqrt{ }$ & $\sqrt{ }$ & $\sqrt{ }$ & $\sqrt{ }$ & $\sqrt{ }$ \\
\hline Buteo polyosoma & LSUMZ 32401 & Cajamarca, Perú & $T$ & Espécime & $\sqrt{ }$ & $\sqrt{ }$ & $\sqrt{ }$ & $\sqrt{ }$ & $\sqrt{ }$ & $\sqrt{ }$ & $\sqrt{ }$ \\
\hline Buteo polyosoma & LSUMZ 5135 & Lambayque, Perú & $T$ & Espécime & $\sqrt{ }$ & $\sqrt{ }$ & $\sqrt{ }$ & $\sqrt{ }$ & $\sqrt{ }$ & $\sqrt{ }$ & $\sqrt{ }$ \\
\hline Buteo regalis & LSUMZ 26245 & Colorado, EUA & $T$ & Espécime & $\sqrt{ }$ & $\sqrt{ }$ & $\sqrt{ }$ & $\sqrt{ }$ & $\sqrt{ }$ & $\sqrt{ }$ & $\sqrt{ }$ \\
\hline Buteo regalis & LSUMZ 4089 & Louisiana, EUA & $T$ & Espécime & $\sqrt{ }$ & $\sqrt{ }$ & $\sqrt{ }$ & $\sqrt{ }$ & $\sqrt{ }$ & $N / D$ & $\sqrt{ }$ \\
\hline Buteo ridgwayi & LSUMZ Pend. & República Dominicana & $S$ & Fotografia & $\sqrt{ }$ & $\sqrt{ }$ & $\sqrt{ }$ & $\sqrt{ }$ & $\sqrt{ }$ & $\sqrt{ }$ & N/D \\
\hline Buteo ridgwayi & LSUMZ Pend. & República Dominicana & $S$ & Fotografia & $\sqrt{ }$ & $\sqrt{ }$ & $\sqrt{ }$ & $\sqrt{ }$ & $\sqrt{ }$ & $\sqrt{ }$ & $\sqrt{ }$ \\
\hline Buteo solitarius & LSUMZ Pend. & Havaí, EUA & $S$ & Espécime & $\sqrt{ }$ & $\sqrt{ }$ & $\sqrt{ }$ & $\sqrt{ }$ & $\sqrt{ }$ & $\sqrt{ }$ & $\sqrt{ }$ \\
\hline Buteo swainsoni & LSUMZ 23586 & Novo México, EUA & $\mathrm{T}$ & Espécime & $\sqrt{ }$ & $\sqrt{ }$ & $\sqrt{ }$ & $\sqrt{ }$ & $\sqrt{ }$ & $\sqrt{ }$ & $\sqrt{ }$ \\
\hline Buteo swainsoni & LSUMZ 4035 & Louisiana, EUA & $T$ & Espécime & $\sqrt{ }$ & $\sqrt{ }$ & $\sqrt{ }$ & $\sqrt{ }$ & $\sqrt{ }$ & $\sqrt{ }$ & $\sqrt{ }$ \\
\hline Buteo ventralis & MNHV Bvenl & Argentina & $\mathrm{TP}$ & Espécime & $N / D$ & $N / D$ & $\sqrt{ }$ & $N / D$ & $N / D$ & $N / D$ & $N / D$ \\
\hline Buteogallus aequinoctialis & ANSP 8182 & Mahaica-Berbice, Guiana & $\mathrm{T}$ & Espécime & $\sqrt{ }$ & $\sqrt{ }$ & $\sqrt{ }$ & $\sqrt{ }$ & $\sqrt{ }$ & $\sqrt{ }$ & $\sqrt{ }$ \\
\hline Buteogallus aequinoctialis & ANSP 8183 & Mahaica-Berbice, Guiana & $\mathrm{T}$ & Espécime & $\sqrt{ }$ & $\sqrt{ }$ & $\sqrt{ }$ & $\sqrt{ }$ & $\sqrt{ }$ & $\sqrt{ }$ & $\sqrt{ }$ \\
\hline Buteogallus anthracinus anthracinus & LSUMZ 28574 & Panamá & $\mathrm{T}$ & Espécime & $\sqrt{ }$ & $\sqrt{ }$ & $\sqrt{ }$ & $\sqrt{ }$ & $\sqrt{ }$ & $\sqrt{ }$ & $\sqrt{ }$ \\
\hline Buteogallus a. anthracinus & LSUMZ 28575 & Panamá & $\mathrm{T}$ & Espécime & $\sqrt{ }$ & $\sqrt{ }$ & $\sqrt{ }$ & $\sqrt{ }$ & $\sqrt{ }$ & $\sqrt{ }$ & $\sqrt{ }$ \\
\hline Buteogallus a. anthracinus & LSUMZ 39641 & Arizona, EUA & $\mathrm{T}$ & Espécime & $\sqrt{ }$ & $\sqrt{ }$ & $\sqrt{ }$ & $\sqrt{ }$ & $\sqrt{ }$ & $\sqrt{ }$ & $\sqrt{ }$ \\
\hline Buteogallus a. subtilis & ANSP 4240 & Guayas, Equador & $\mathrm{T}$ & Espécime & $\sqrt{ }$ & $\sqrt{ }$ & $\sqrt{ }$ & $\sqrt{ }$ & $\sqrt{ }$ & $N / D$ & N/D \\
\hline Buteogallus meridionalis & LSUMZ 48561 & Guiana & $\mathrm{T}$ & Espécime & $\sqrt{ }$ & $\sqrt{ }$ & $\sqrt{ }$ & $\sqrt{ }$ & $\sqrt{ }$ & $N / D$ & $\sqrt{ }$ \\
\hline Buteogallus meridionalis & LGEMA F54 & São Paulo, Brasil & $T$ & Espécime & $\sqrt{ }$ & $\sqrt{ }$ & $\sqrt{ }$ & $\sqrt{ }$ & $\sqrt{ }$ & $\sqrt{ }$ & $\sqrt{ }$ \\
\hline Buteogallus urubitinga & LSUMZ 2176 & Darien, Panamá & $\mathrm{T}$ & Espécime & $\sqrt{ }$ & $\sqrt{ }$ & $\sqrt{ }$ & $\sqrt{ }$ & $\sqrt{ }$ & $\sqrt{ }$ & $\sqrt{ }$ \\
\hline
\end{tabular}




\begin{tabular}{|c|c|c|c|c|c|c|c|c|c|c|c|}
\hline Espécie & Amostra & Localidade & Material & Testemunho & $12 S$, Val, $16 \mathrm{~S}$ & ATP8/6 & ND6 & Cy+B & ND2 & LDH & FIB5 \\
\hline Buteogallus urubitinga & LGEMA F72 & Desconhecida & $S$ & Fotografia & $\sqrt{ }$ & $\sqrt{ }$ & $\sqrt{ }$ & $\sqrt{ }$ & $\sqrt{ }$ & $\sqrt{ }$ & $\sqrt{ }$ \\
\hline Geranoaetus melanoleucus & LGEMA F151 & Desconhecida & PS & Fotografia & $\sqrt{ }$ & $\sqrt{ }$ & $\sqrt{ }$ & $\sqrt{ }$ & $\sqrt{ }$ & $\sqrt{ }$ & $\sqrt{ }$ \\
\hline Geranoaetus melanoleucus & LGEMA F152 & Desconhecida & PS & Fotografia & $\sqrt{ }$ & $\sqrt{ }$ & $\sqrt{ }$ & $\sqrt{ }$ & $\sqrt{ }$ & $\sqrt{ }$ & $\sqrt{ }$ \\
\hline Geranospiza caerulescens caerulescens & LSUMZ 4226 & Loreto, Perú & $T$ & Espécime & $\sqrt{ }$ & $\sqrt{ }$ & $\sqrt{ }$ & $\sqrt{ }$ & $\sqrt{ }$ & $\sqrt{ }$ & $\sqrt{ }$ \\
\hline Geranospiza caerulescens gracilis & LGEMA F84 & Uruçuí-Una, PI, Brasil & T & Espécime & $\sqrt{*}$ & $\sqrt{ }$ & $\sqrt{ }$ & $\sqrt{ }$ & $\sqrt{ }$ & $\sqrt{ }$ & $\sqrt{ }$ \\
\hline Haliaeetus leucocephalus & LSUMZ 49103 & Florida, EUA & T & Espécime & $\sqrt{ }$ & $\sqrt{ }$ & $\sqrt{ }$ & $\sqrt{ }$ & $\sqrt{ }$ & $\sqrt{ }$ & $\sqrt{ }$ \\
\hline Haliaeetus leucocephalus & LSUMZ 21800 & Loiusiana, EUA & T & Espécime & $\sqrt{ }$ & $\sqrt{ }$ & $\sqrt{ }$ & $\sqrt{ }$ & $\sqrt{ }$ & $\sqrt{ }$ & $\sqrt{ }$ \\
\hline Harpagus bidentatus fasciatus & LSUMZ 26407 & Bocas del Toro, Panamá & T & Espécime & $\sqrt{ }$ & $\sqrt{ }$ & $\sqrt{ }$ & $\sqrt{ }$ & $\sqrt{ }$ & $\sqrt{ }$ & $\sqrt{ }$ \\
\hline Harpagus bidentatus bidentatus & LGEMA F14 & Jurvena, MT & $\mathrm{T}$ & Espécime & $\sqrt{ }$ & $\sqrt{ }$ & $\sqrt{ }$ & $\sqrt{ }$ & $\sqrt{ }$ & $\sqrt{ }$ & $\sqrt{ }$ \\
\hline Harpagus diodon & LGEMA F88 & Bananal, São Paulo & $\mathrm{T}$ & Espécime & $\sqrt{ }$ & $\sqrt{ }$ & $\sqrt{ }$ & $\sqrt{ }$ & $\sqrt{ }$ & $\sqrt{ }$ & $\sqrt{ }$ \\
\hline Harpyhaliaetus coronatus & LGEMA F120 & Teresópolis, RJ, Brasil & $\mathrm{T}$ & Espécime & $\sqrt{ }$ & $\sqrt{ }$ & $\sqrt{ }$ & $\sqrt{ }$ & $\sqrt{ }$ & $\sqrt{ }$ & $\sqrt{ }$ \\
\hline Harpyhaliaetus coronatus & LGEMA F44 & MG, Brasil & $S$ & Fotografia & $\sqrt{ }$ & $\sqrt{ }$ & $\sqrt{ }$ & $\sqrt{ }$ & $\sqrt{ }$ & $\sqrt{ }$ & $\sqrt{ }$ \\
\hline Harpyhaliaetus coronatus & LGEMA F45 & Ubá, Minas Gerais, Brasil & $S$ & Fotografia & $\sqrt{ }$ & $\sqrt{ }$ & $\sqrt{ }$ & $\sqrt{ }$ & $\sqrt{ }$ & $\sqrt{ }$ & $\sqrt{ }$ \\
\hline Harpyhaliaetus solitarius & LSUMZ 22903 & La Paz, Bolívia & $\mathrm{T}$ & Espécime & $\sqrt{ }$ & $\sqrt{ }$ & $\sqrt{ }$ & $\sqrt{ }$ & $\sqrt{ }$ & $\sqrt{ }$ & $\sqrt{ }$ \\
\hline Ictinia mississipiensis & LSUMZ 20820 & Louisiana, EUA & $\mathrm{T}$ & Espécime & $\sqrt{ }$ & $\sqrt{ }$ & $\sqrt{ }$ & $\sqrt{ }$ & $\sqrt{ }$ & $\sqrt{ }$ & $\sqrt{ }$ \\
\hline Ictinia plumbea & LGEMA F123 & São Paulo, SP, Brasil & $\mathrm{T}$ & Espécime & $\sqrt{ }$ & $\sqrt{ }$ & $\sqrt{ }$ & $\sqrt{ }$ & $\sqrt{ }$ & $\sqrt{ }$ & $\sqrt{ }$ \\
\hline Leucopternis albicollis albicollis & LSUMZ 40297 & Loreto, Perú & $\mathrm{T}$ & Espécime & $\sqrt{ }$ & $\sqrt{ }$ & $\sqrt{ }$ & $\sqrt{ }$ & $\sqrt{ }$ & $N / D$ & N/D \\
\hline Leucopternis albicollis albicollis & LGEMA 10540 & Tailândia, Pará & $\mathrm{T}$ & Espécime & $\sqrt{ }$ & $\sqrt{ }$ & $\sqrt{ }$ & $\sqrt{ }$ & $\sqrt{ }$ & $\sqrt{ }$ & $\sqrt{ }$ \\
\hline Leucopternis a. costaricensis & LSUMZ 46458 & Panamá & $\mathrm{T}$ & Espécime & $\sqrt{ }$ & $\sqrt{ }$ & $\sqrt{ }$ & $\sqrt{ }$ & $\sqrt{ }$ & $\sqrt{ }$ & $\sqrt{ }$ \\
\hline Leucopternis a. costaricensis & LSUMZ 2312 & Darien, Panamá & $\mathrm{T}$ & Espécime & $\sqrt{ }$ & $\sqrt{ }$ & $\sqrt{ }$ & $N / D$ & $\sqrt{ }$ & $N / D$ & $\sqrt{ }$ \\
\hline Leucopternis a. costaricensis & LGEMA F52 & Panamá & PS & Penas & $\sqrt{ }$ & $\sqrt{ }$ & $\sqrt{ }$ & $\sqrt{ }$ & $\sqrt{ }$ & $N / D$ & $\sqrt{ }$ \\
\hline Leucopternis a. ghiesbreghti & LGEMA F57 & México & $S$ & Fotografia & $\sqrt{ }$ & $\sqrt{ }$ & $\sqrt{ }$ & $\sqrt{ }$ & $\sqrt{ }$ & $\sqrt{ }$ & $\sqrt{ }$ \\
\hline Leucopternis a. ghiesbreghti & LGEMA F58 & México & $S$ & Fotografia & $\sqrt{ }$ & $\sqrt{ }$ & $\sqrt{ }$ & $\sqrt{ }$ & $\sqrt{ }$ & $\sqrt{ }$ & $\sqrt{ }$ \\
\hline
\end{tabular}




\begin{tabular}{|c|c|c|c|c|c|c|c|c|c|c|c|}
\hline Espécie & Amostra & Localidade & Material & Testemunho & $12 S$, Val, $16 \mathrm{~S}$ & ATP8/6 & ND6 & CytB & ND2 & LDH & FIB5 \\
\hline Leucopternis kuhli & LSUMZ 4598 & Loreto, Perú & $\mathrm{T}$ & Espécime & $\sqrt{ }$ & $\sqrt{ }$ & $\sqrt{ }$ & $\sqrt{ }$ & $\sqrt{ }$ & $\sqrt{ }$ & $\sqrt{ }$ \\
\hline Leucopternis kuhli & LGEMA F145 & Tailândia, Pará, Brasil & $T$ & Espécime & $\sqrt{ }$ & $\sqrt{ }$ & $\sqrt{ }$ & $\sqrt{ }$ & $\sqrt{ }$ & $\sqrt{ }$ & $\sqrt{ }$ \\
\hline Leucopternis lacernulatus & LGEMA F39 & Praia Grande, SP, Brasil & $T$ & Espécime & $\sqrt{ }$ & $\sqrt{ }$ & $\sqrt{ }$ & $\sqrt{ }$ & $\sqrt{ }$ & $\sqrt{ }$ & $\sqrt{ }$ \\
\hline Leucopternis melanops & ANSP 7554 & Guiana & $\mathrm{T}$ & Espécime & $\sqrt{ }$ & $\sqrt{ }$ & $\sqrt{ }$ & $\sqrt{ }$ & $\sqrt{ }$ & $\mathrm{N} / \mathrm{D}$ & $N / D$ \\
\hline Leucopternis melanops & ANSP 7883 & Guiana & $\mathrm{T}$ & Espécime & $\sqrt{ }$ & $\sqrt{ }$ & $\sqrt{ }$ & $\sqrt{ }$ & $\sqrt{ }$ & $\mathrm{N} / \mathrm{D}$ & $N / D$ \\
\hline Leucopternis melanops & LSUMZ 4493 & Loreto, Perú & $\mathrm{T}$ & Espécime & $\sqrt{ }$ & $\sqrt{ }$ & $\sqrt{ }$ & $\sqrt{ }$ & $\sqrt{ }$ & $\sqrt{ }$ & $\sqrt{ }$ \\
\hline Leucopternis melanops & LSUMZ 7167 & Loreto, Perú & $T$ & Espécime & $\sqrt{ }$ & $\sqrt{ }$ & $\sqrt{ }$ & $\sqrt{ }$ & $\sqrt{ }$ & $\sqrt{ }$ & $\sqrt{ }$ \\
\hline Leucopternis occidentalis & ANSP 2901 & Equador & $T$ & Espécime & $\sqrt{ }$ & $\sqrt{ }$ & $\sqrt{ }$ & $\sqrt{ }$ & $\sqrt{ }$ & $\mathrm{N} / \mathrm{D}$ & $N / D$ \\
\hline Leucopternis occidentalis & ANSP 4321 & Equador & $\mathrm{T}$ & Espécime & $\sqrt{ }$ & $\sqrt{ }$ & $\sqrt{ }$ & $\sqrt{ }$ & $\sqrt{ }$ & N/D & $N / D$ \\
\hline Leucopternis occidentalis & LSUMZ 7805 & El Oro, Equador & T & Espécime & $\sqrt{ }$ & $\sqrt{ }$ & $\sqrt{ }$ & $\sqrt{ }$ & $\sqrt{ }$ & $\mathrm{N} / \mathrm{D}$ & $\sqrt{ }$ \\
\hline Leucopternis occidentalis & LSUMZ 7890 & El Oro, Equador & $\mathrm{T}$ & Espécime & $\sqrt{ }$ & $\sqrt{ }$ & $\sqrt{ }$ & $\sqrt{ }$ & $\sqrt{ }$ & $\sqrt{ }$ & $\sqrt{ }$ \\
\hline Leucopternis plumbeus & ANSP 780 & Equador & $\mathrm{T}$ & Espécime & $\sqrt{ }$ & $\sqrt{ }$ & $\sqrt{ }$ & $N / D$ & $N / D$ & $\mathrm{~N} / \mathrm{D}$ & $N / D$ \\
\hline Leucopternis plumbeus & ANSP 2241 & Equador & $\mathrm{T}$ & Espécime & $\sqrt{ }$ & $\sqrt{ }$ & $\sqrt{ }$ & $\sqrt{ }$ & $\sqrt{ }$ & $\mathrm{N} / \mathrm{D}$ & $N / D$ \\
\hline Leucopternis polionotus & LGEMA F55 & Desconhecida & PS & Fotografia & $\sqrt{ }$ & $\sqrt{ }$ & $\sqrt{ }$ & $\sqrt{ }$ & $\sqrt{ }$ & $\sqrt{ }$ & $\sqrt{ }$ \\
\hline Leucopternis princeps & LSUMZ 11751 & Esmeraldas, Equador & T & Espécime & $\sqrt{ }$ & $\sqrt{ }$ & $\sqrt{ }$ & $\sqrt{ }$ & $\sqrt{ }$ & $\sqrt{ }$ & $\sqrt{ }$ \\
\hline Leucopternis schistaceus & LSUMZ 4946 & Loreto, Perú & $\mathrm{T}$ & Espécime & $\sqrt{ }$ & $\sqrt{ }$ & $\sqrt{ }$ & $\sqrt{ }$ & $\sqrt{ }$ & $\sqrt{ }$ & $\sqrt{ }$ \\
\hline Leucopternis schistaceus & ANSP 3270 & Napo, Equador & $\mathrm{T}$ & Espécime & $\sqrt{ }$ & $\sqrt{ }$ & $\sqrt{ }$ & $\sqrt{ }$ & $\sqrt{ }$ & $N / D$ & $N / D$ \\
\hline Leucopternis semiplumbeus & LSUMZ 2291 & Darien, Panamá & $\mathrm{T}$ & Espécime & $\sqrt{ }$ & $\sqrt{ }$ & $\sqrt{ }$ & $\sqrt{ }$ & $\sqrt{ }$ & $\sqrt{ }$ & $\sqrt{ }$ \\
\hline Leucopternis semiplumbeus & LSUMZ 2326 & Darien, Panamá & T & Espécime & $\sqrt{ }$ & $\sqrt{ }$ & $\sqrt{ }$ & $\sqrt{ }$ & $\sqrt{ }$ & $\sqrt{ }$ & $\sqrt{ }$ \\
\hline Parabuteo unicinctus & LSUMZ 40769 & Loreto, Perú & $\mathrm{T}$ & Espécime & $\sqrt{ }$ & $\sqrt{ }$ & $\sqrt{ }$ & $\sqrt{ }$ & $\sqrt{ }$ & $\sqrt{ }$ & $\sqrt{ }$ \\
\hline Parabuteo unicinctus & LGEMA F91 & Baixada Santista, SP, Brasil & PS & Fotografia & $\sqrt{ }$ & $\sqrt{ }$ & $\sqrt{ }$ & $\sqrt{ }$ & $\sqrt{ }$ & $\sqrt{ }$ & $\sqrt{ }$ \\
\hline Parabuteo unicinctus & LGEMA F93 & Rio de Janeiro, Brasil & PS & Fotografia & $\sqrt{ }$ & $\sqrt{ }$ & $\sqrt{ }$ & $\sqrt{ }$ & $\sqrt{ }$ & $\sqrt{ }$ & $\sqrt{ }$ \\
\hline Rostrhamus sociabilis & LSUMZ 49411 & Florida, EUA & T & Espécime & $\sqrt{ }$ & $\sqrt{ }$ & $\sqrt{ }$ & $\sqrt{ }$ & $\sqrt{ }$ & $\sqrt{ }$ & $\sqrt{ }$ \\
\hline
\end{tabular}




\section{Continuação do Anexo A}

\begin{tabular}{|c|c|c|c|c|c|c|c|c|c|c|c|}
\hline Espécie & Amostra & Localidade & Material & Testemunho & $12 S$, Val, $16 \mathrm{~S}$ & ATP8/6 & ND6 & CytB & ND2 & LDH & FIB5 \\
\hline \multicolumn{12}{|l|}{ Velho Mundo } \\
\hline Buteo auguralis & MNHV Bagl 1 & Nigéria & TP & Espécime & $N / D$ & $N / D$ & $\sqrt{ }$ & $N / D$ & $N / D$ & N/D & N/D \\
\hline Buteo augur & LSUMZ Pend. & Desconhecida & $S$ & Fotografia & $\sqrt{ }$ & $\sqrt{ }$ & $\sqrt{ }$ & $\sqrt{ }$ & $\sqrt{ }$ & $\sqrt{ }$ & $\sqrt{ }$ \\
\hline Buteo buteo buteo & MNHV Bbutbut2 & Áustria & $S$ & $N / D$ & $\sqrt{ }$ & $\sqrt{ }$ & $\sqrt{ }$ & $\sqrt{ }$ & $\sqrt{ }$ & $N / D$ & N/D \\
\hline Buteo buteo vulpinus & MNHV Bbutvul8 & Eilat, Israel & $S$ & $N / D$ & $\sqrt{ } *$ & $\sqrt{ }$ & $\sqrt{ }$ & $N / D$ & N/D & $N / D$ & N/D \\
\hline Buteo hemilasius & MNHV Bhem 12 & Ulaanbaatar, Mongólia & $P$ & $N / D$ & $\sqrt{*}$ & $\sqrt{ }$ & $\sqrt{ }$ & $N / D$ & $N / D$ & $N / D$ & $N / D$ \\
\hline Buteo hemilasius & MNHV Bhem 16 & Desconhecida & $S$ & $N / D$ & $\sqrt{*}$ & $\sqrt{ }$ & $\sqrt{ }$ & $N / D$ & $N / D$ & $N / D$ & N/D \\
\hline Buteo hemilasius & MNHV Bhem5 & Desconhecida & $S$ & $N / D$ & $\sqrt{*}$ & $\sqrt{ }$ & $\sqrt{ }$ & $N / D$ & $N / D$ & $N / D$ & $N / D$ \\
\hline Buteo japonicus & MNHV Bbutjapl0 & Ostoscho, Rússia & $P$ & $N / D$ & $\sqrt{*}$ & $\sqrt{ }$ & $\sqrt{ }$ & $N / D$ & $N / D$ & $N / D$ & N/D \\
\hline Buteo refectus & MNHV Bbutref 11 & Desconhecida & TP & Espécime & $\sqrt{*}$ & $\sqrt{ }$ & $\sqrt{ }$ & N/D & $N / D$ & N/D & $N / D$ \\
\hline Buteo refectus & MNHV Bbutref4 & Kashmira, India & TP & Espécime & $\sqrt{*}$ & $\sqrt{ }$ & $\sqrt{ }$ & $N / D$ & $N / D$ & $N / D$ & $\mathrm{~N} / \mathrm{D}$ \\
\hline Buteo rufinus & MNHV Bruf4 & Desconhecida & $S$ & $N / D$ & $\sqrt{*}$ & $\sqrt{ }$ & $\sqrt{ }$ & $N / D$ & $N / D$ & $N / D$ & N/D \\
\hline Buteo rufinus & MNHV Bruf3 & Eilat, Israel & $S$ & $N / D$ & $\sqrt{*}$ & $\sqrt{ }$ & $\sqrt{ }$ & $N / D$ & $N / D$ & N/D & $N / D$ \\
\hline Buteo rufufuscus & MNHV Brfc3 & África do Sul & $S$ & $N / D$ & $\sqrt{*}$ & $\sqrt{ }$ & $\sqrt{ }$ & $N / D$ & $N / D$ & $N / D$ & N/D \\
\hline Buteo rufofuscus & MNHV Brfc5 & Desconhecida & $S$ & $N / D$ & $\sqrt{*}$ & $\sqrt{ }$ & $\sqrt{ }$ & $\mathrm{N} / \mathrm{D}$ & $\mathrm{N} / \mathrm{D}$ & $\mathrm{N} / \mathrm{D}$ & $\mathrm{N} / \mathrm{D}$ \\
\hline
\end{tabular}


Anexo B. Estrutura secundária do tRNA Valina utilizada nas análises filogenéticas, ilustrada em Buteo buteo.

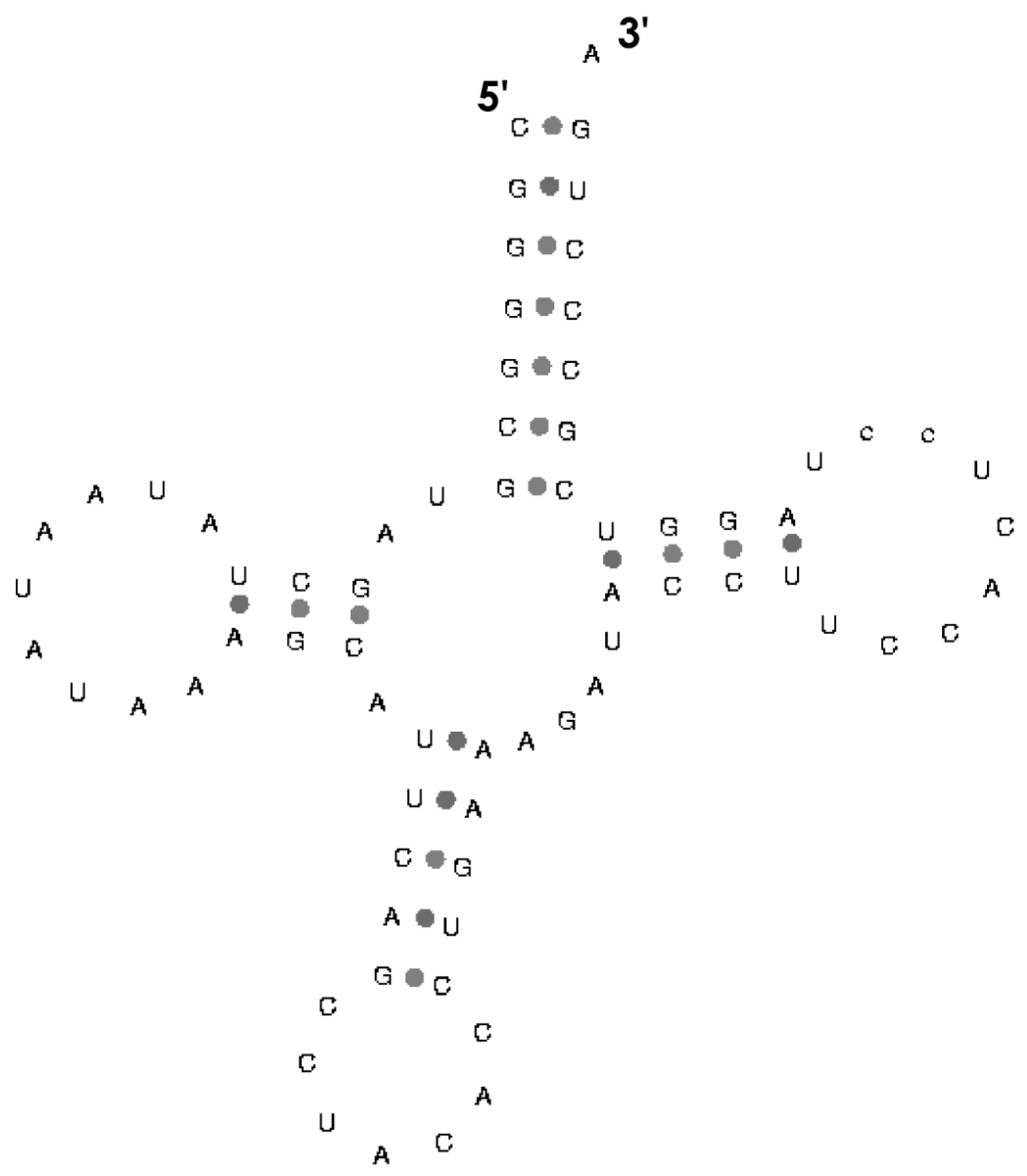


Anexo C. Gráficos de saturação
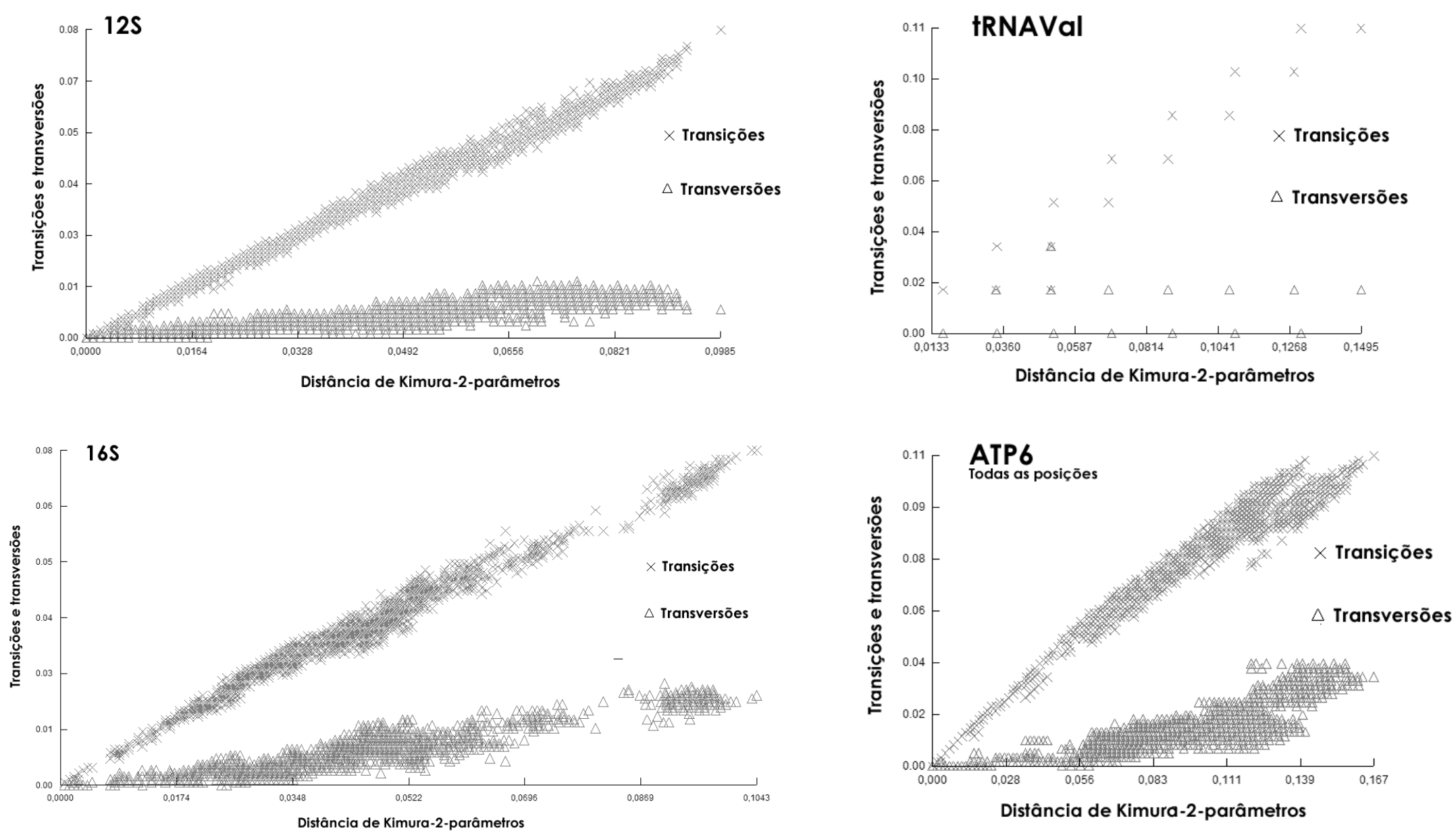
Continuação do Anexo C.
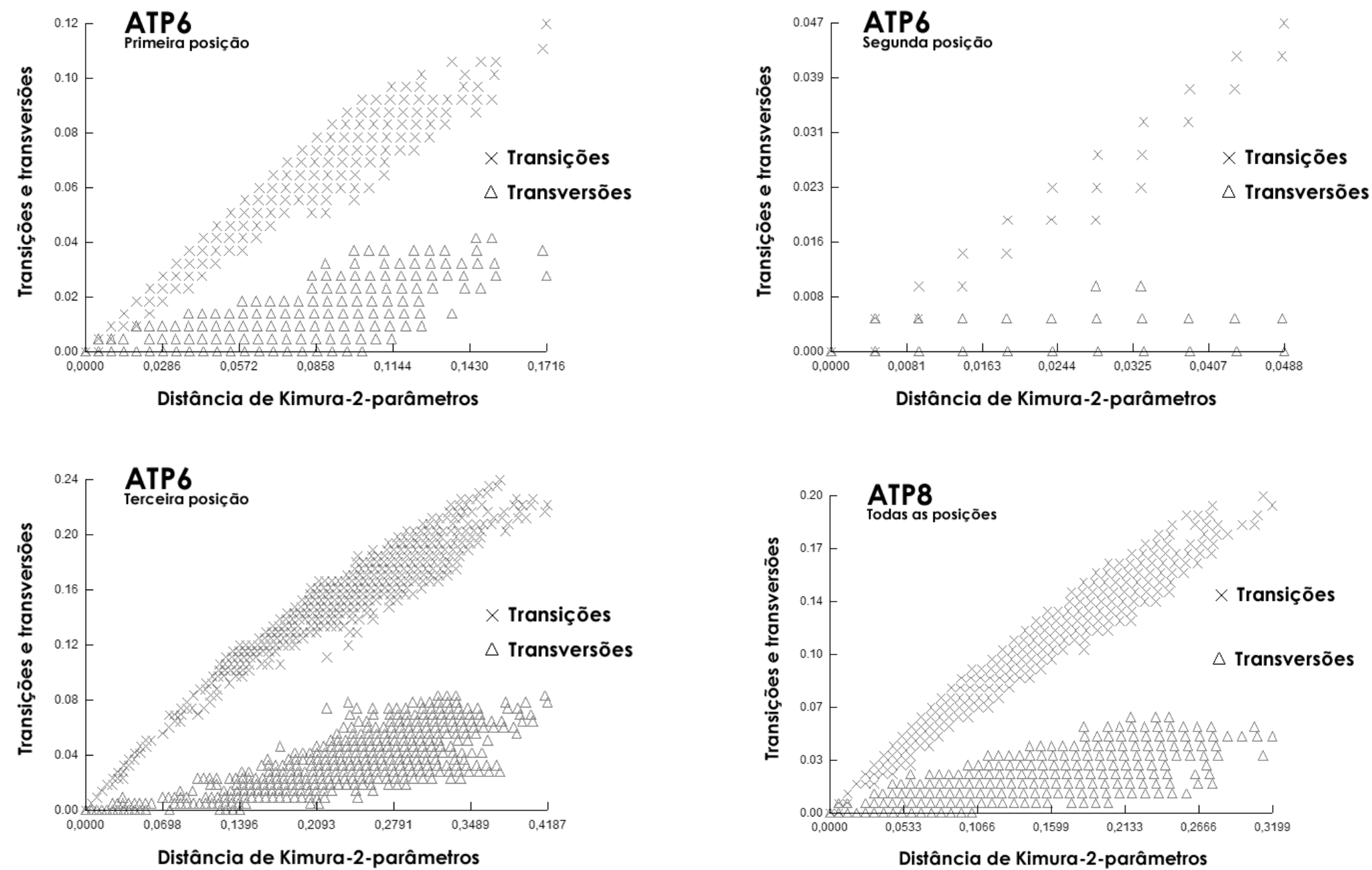


\section{Continuação do Anexo C.}
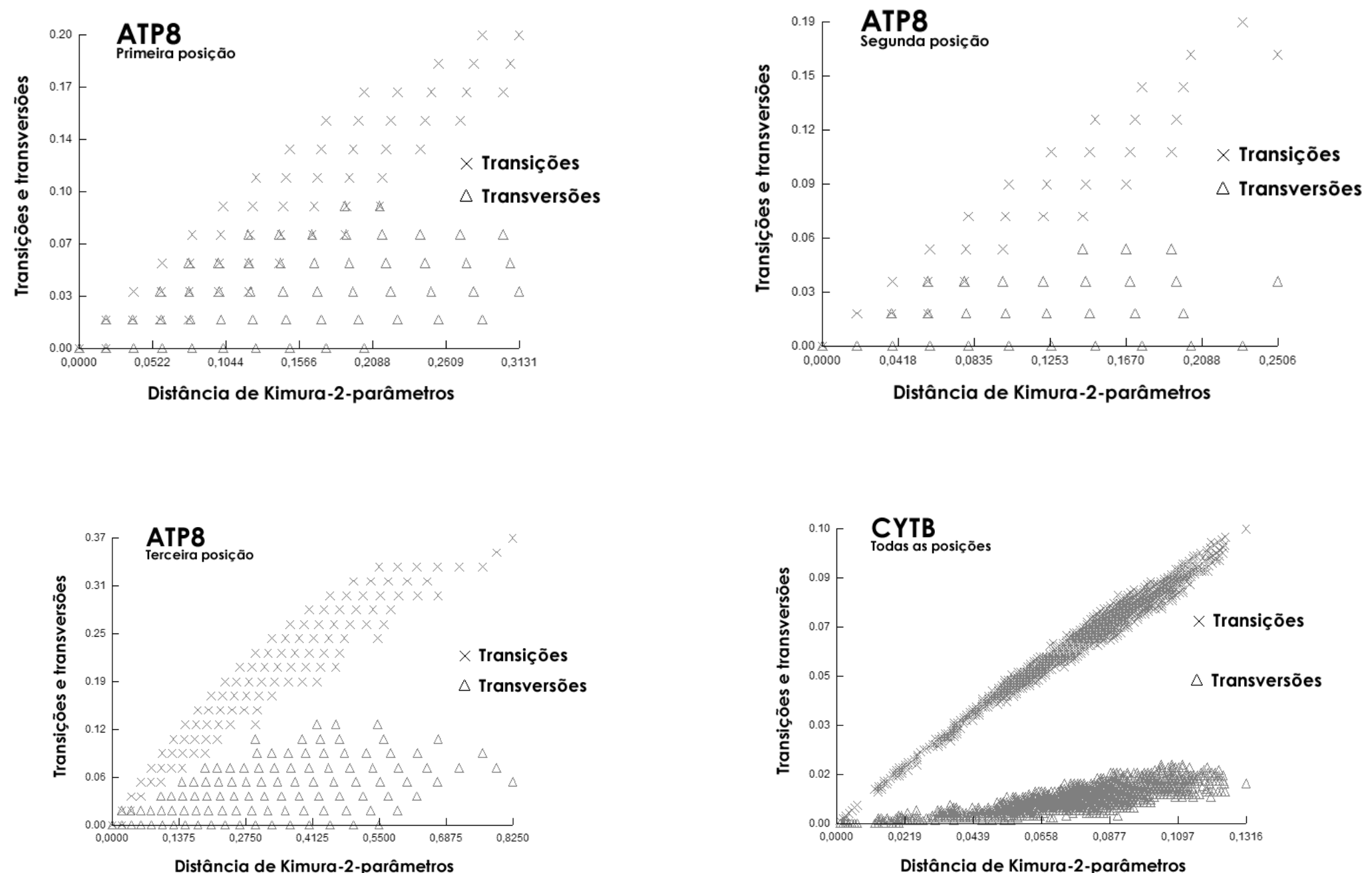
Continuação do Anexo C.
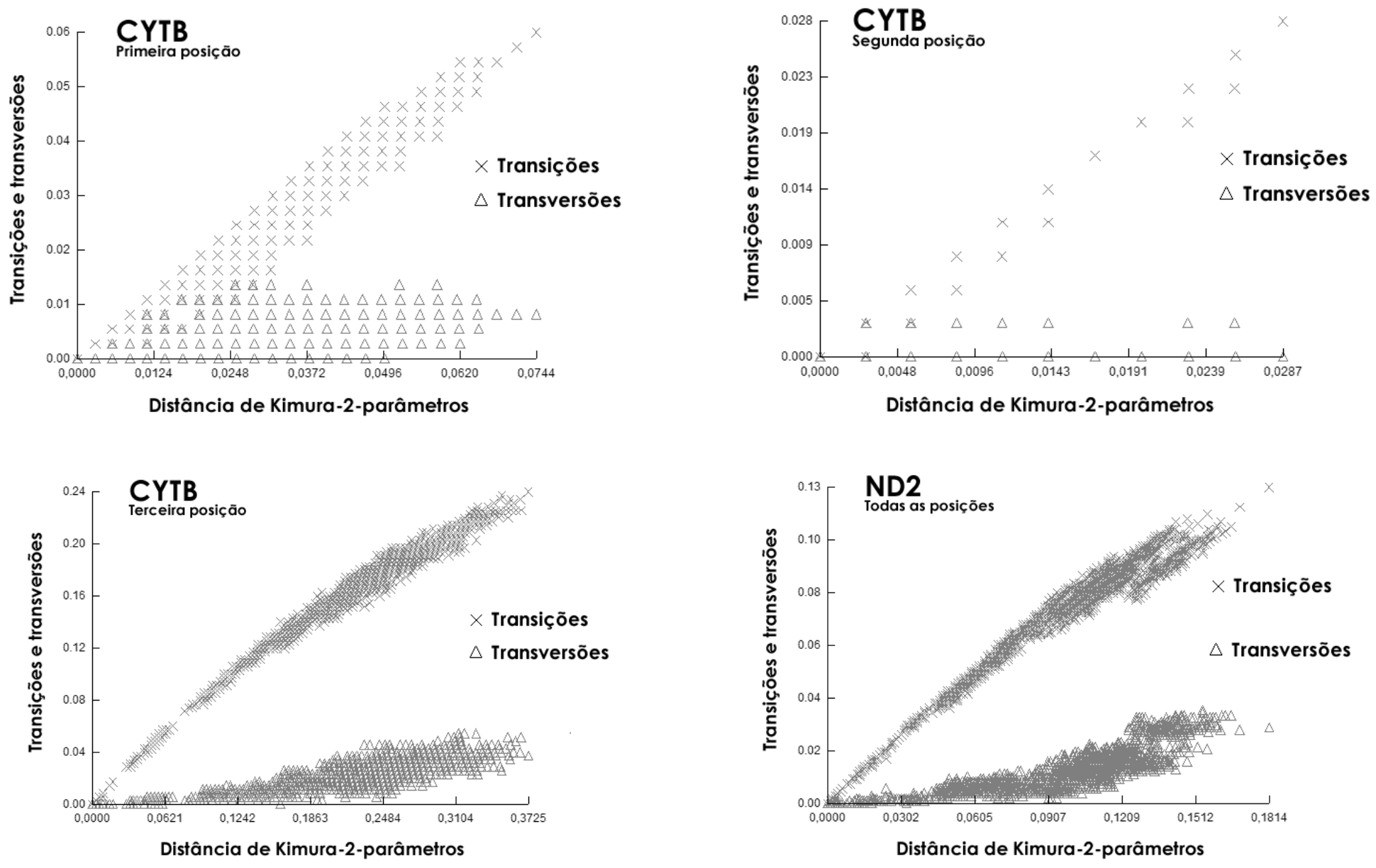


\section{Continuação do Anexo C.}

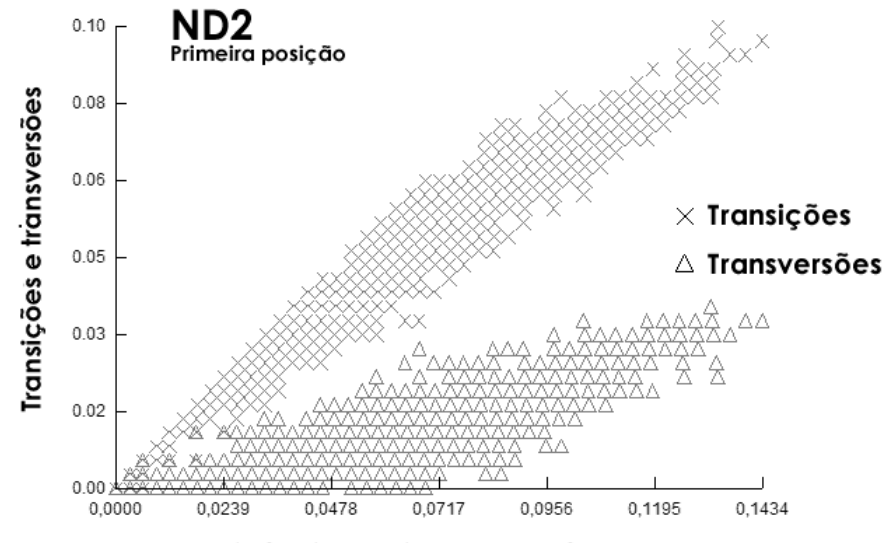

Distância de Kimura-2-parâmetros

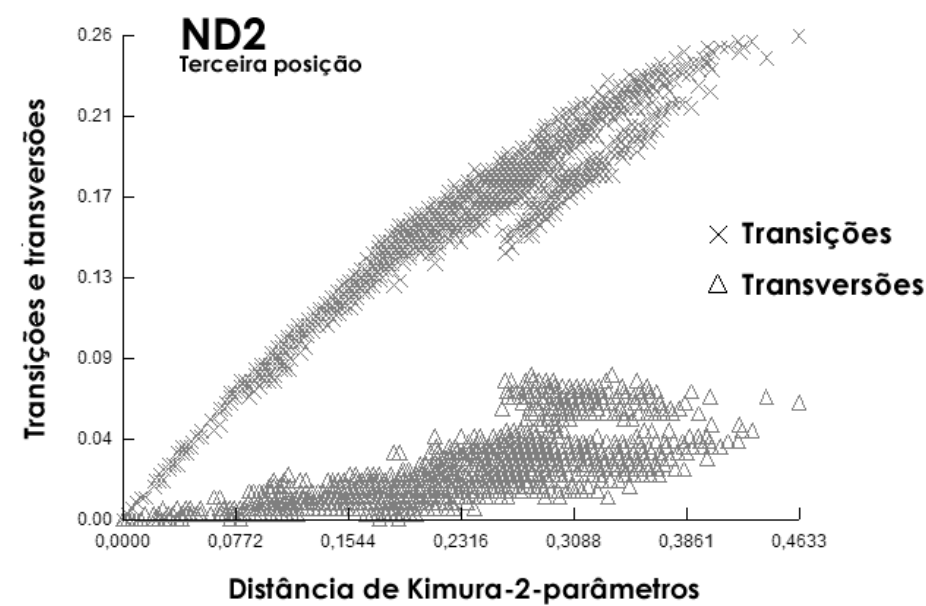

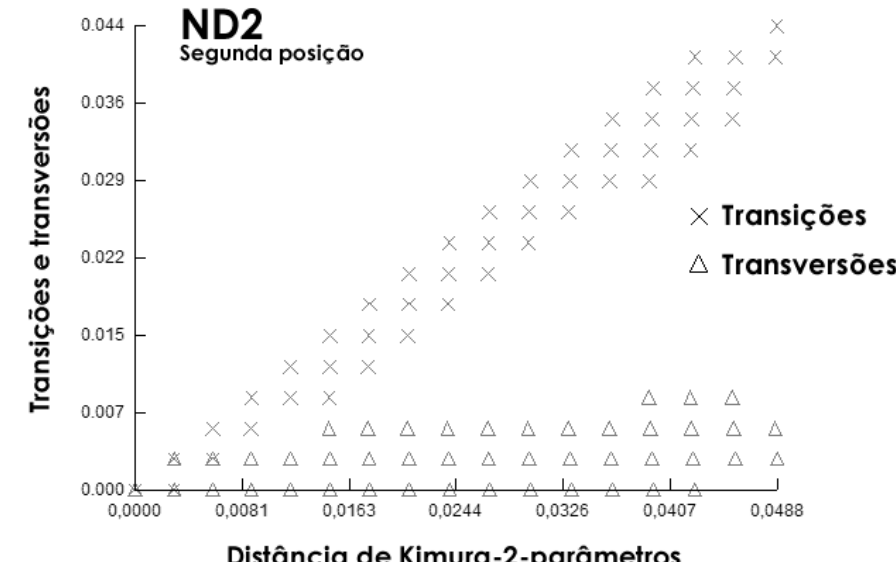

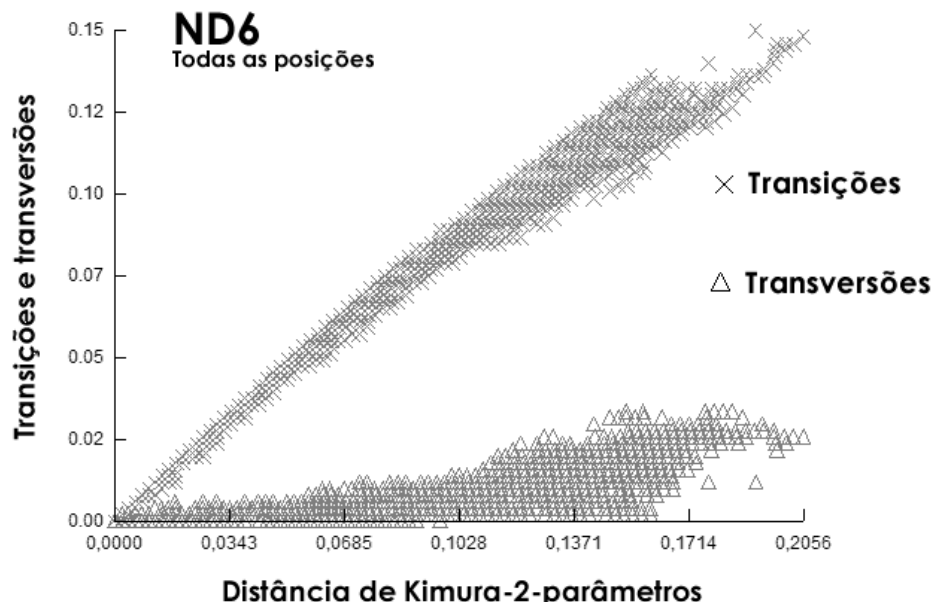


Continuação do Anexo C.
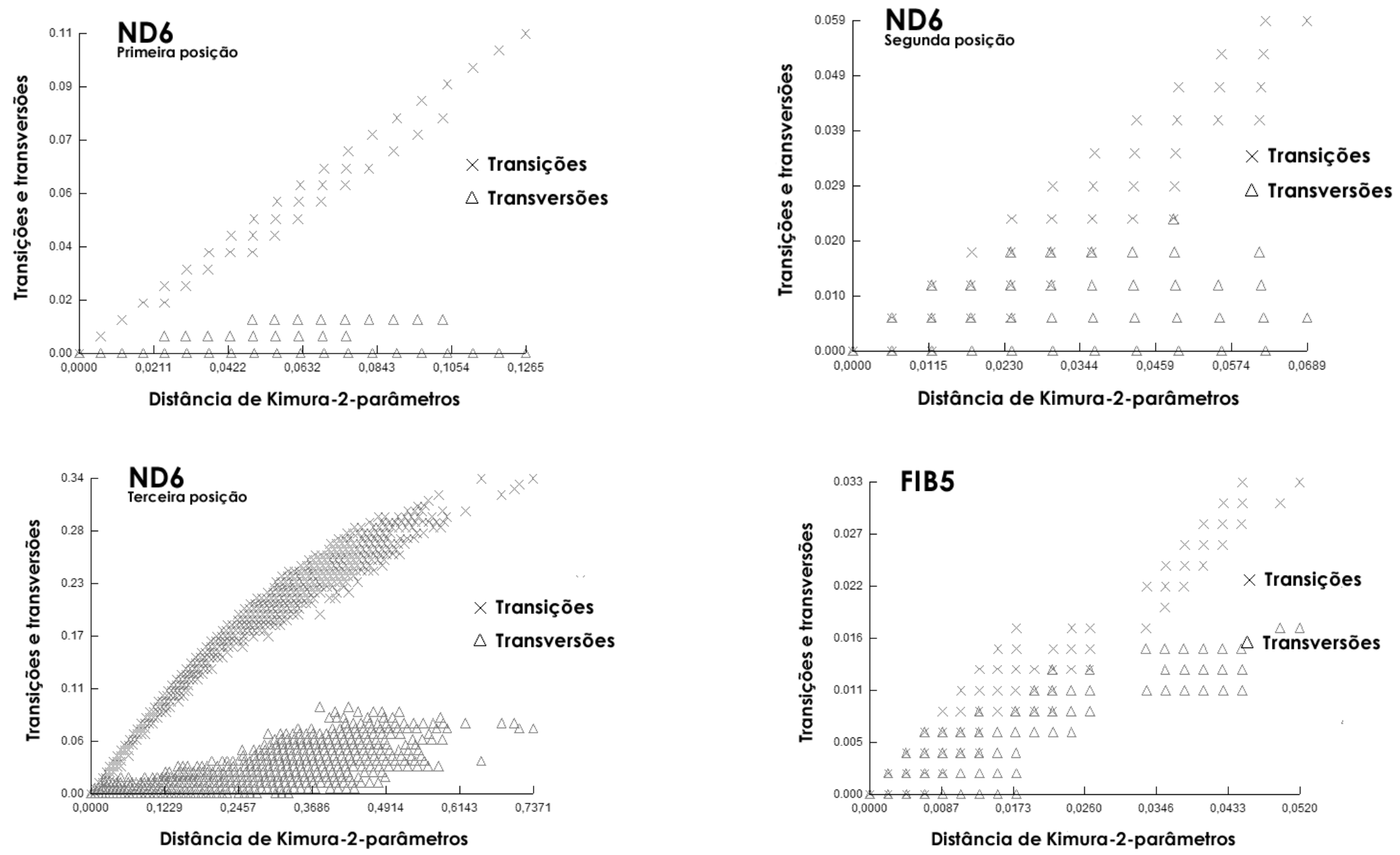


\section{Continuação do Anexo C.}

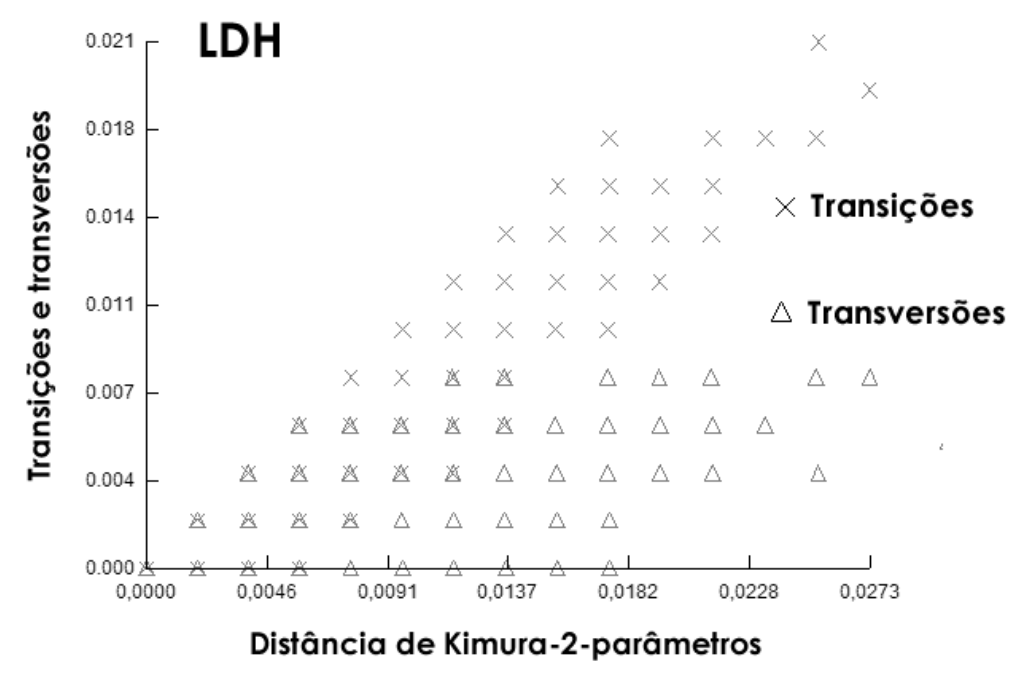


Anexo D. Topologia de máxima versomilhança (-In 12653.6444) da partição 12S+tRNAVal+16S. Números próximos aos nós correspondem a valores de bootstrap de máxima verossimilhança. Valores em negrito correspodem a bootstrap igual ou maior que 70.

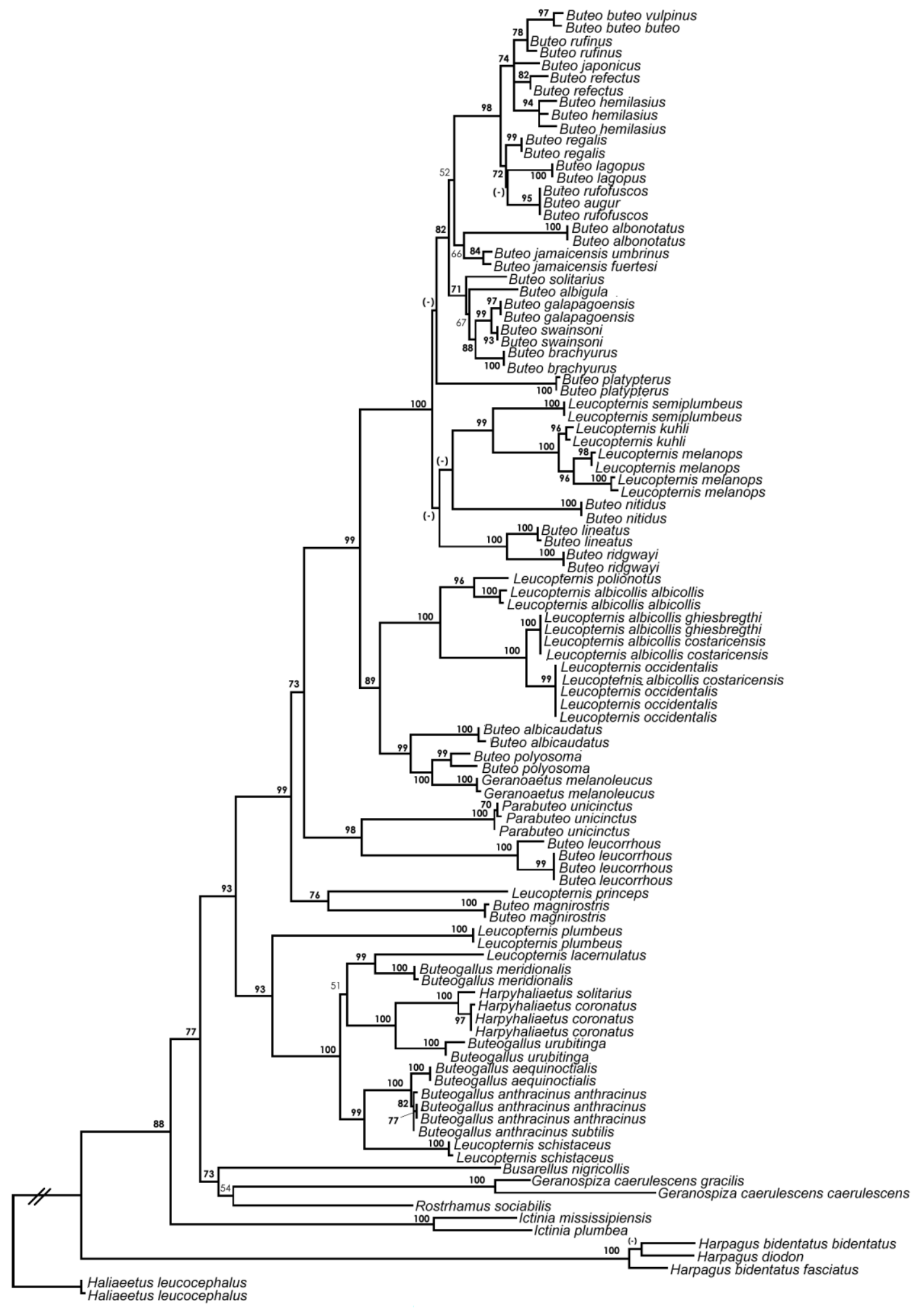

0.1 substituiçōes/sítio 
Anexo E. Topologia de consenso da análise bayesiana da partição 12S+tRNAVal+16S, sem a utilização de dados de estrutura secundária. Números próximos aos ramos representam probabilidades posteriores. Valores em negrito correspondem a probabilidades iguais ou maiores a 0,95.

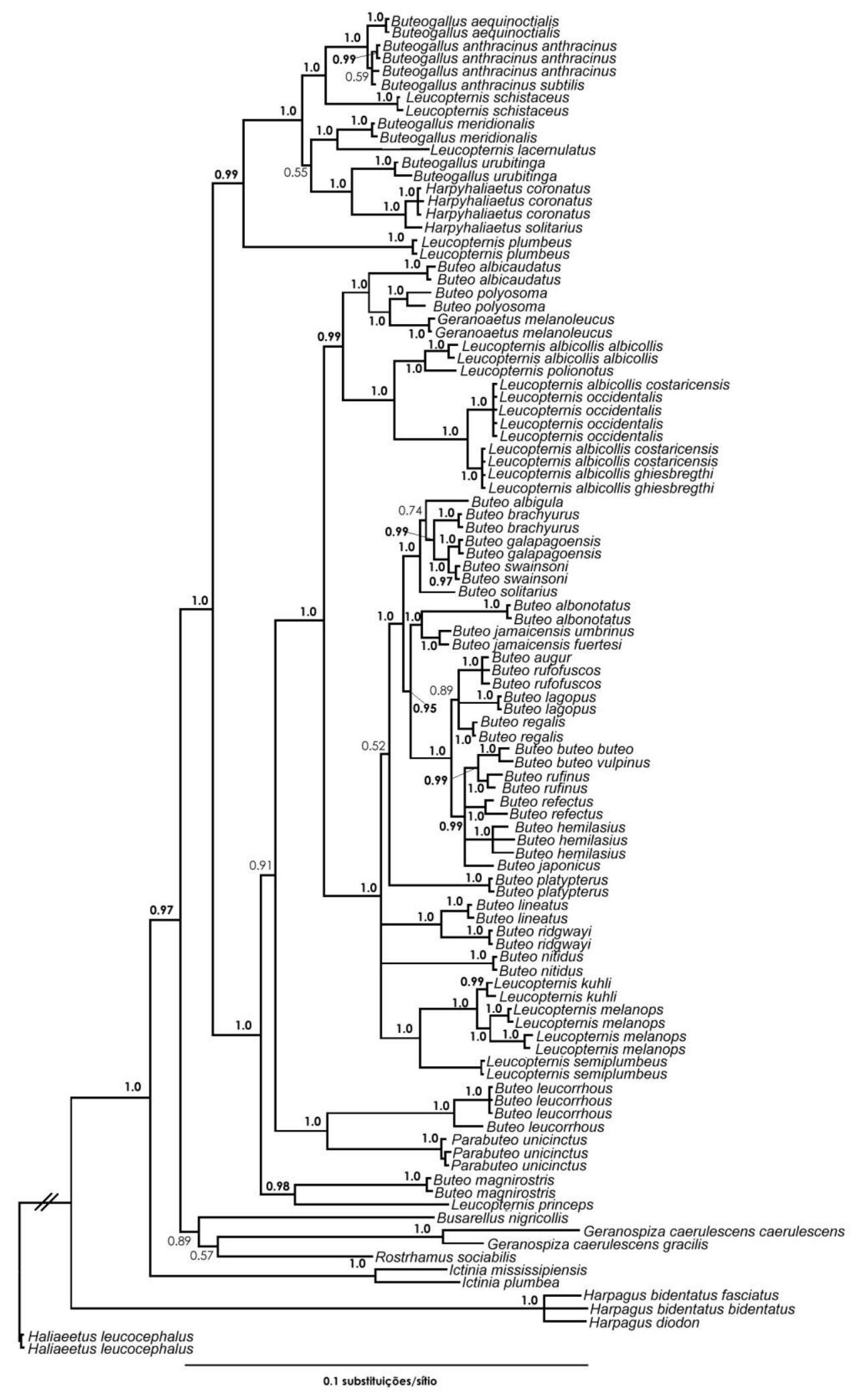


Anexo F. Topologia de consenso da análise bayesiana da partição 12S+†RNAVal+16S com a utilização de dados de estrutura secundária. Números próximos aos ramos representam probabilidades posteriores. Valores em negrito correspondem a probabilidades iguais ou maiores a 0,95.

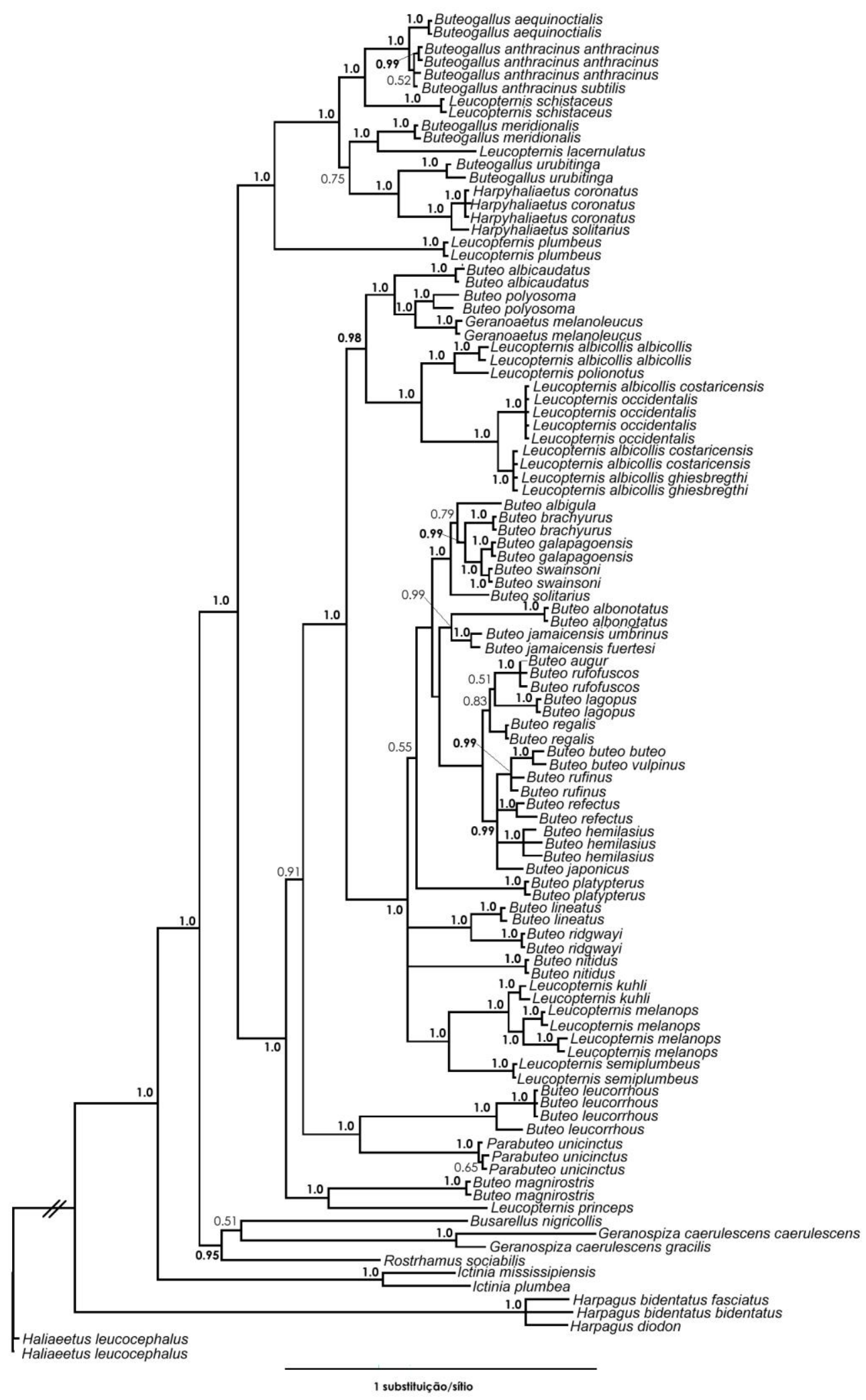


Anexo G. Topologia de máxima versomilhança (-In 7612.8820) da partição ATP8+ATP6. Números próximos aos nós correspondem a valores de probabilidades posteriores e bootstrap de máxima verossimilhança. Valores em negrito correspodem a probabilidades posteriores e bootstrap iguais ou maiores que 0,95 e 70, respectivamente.

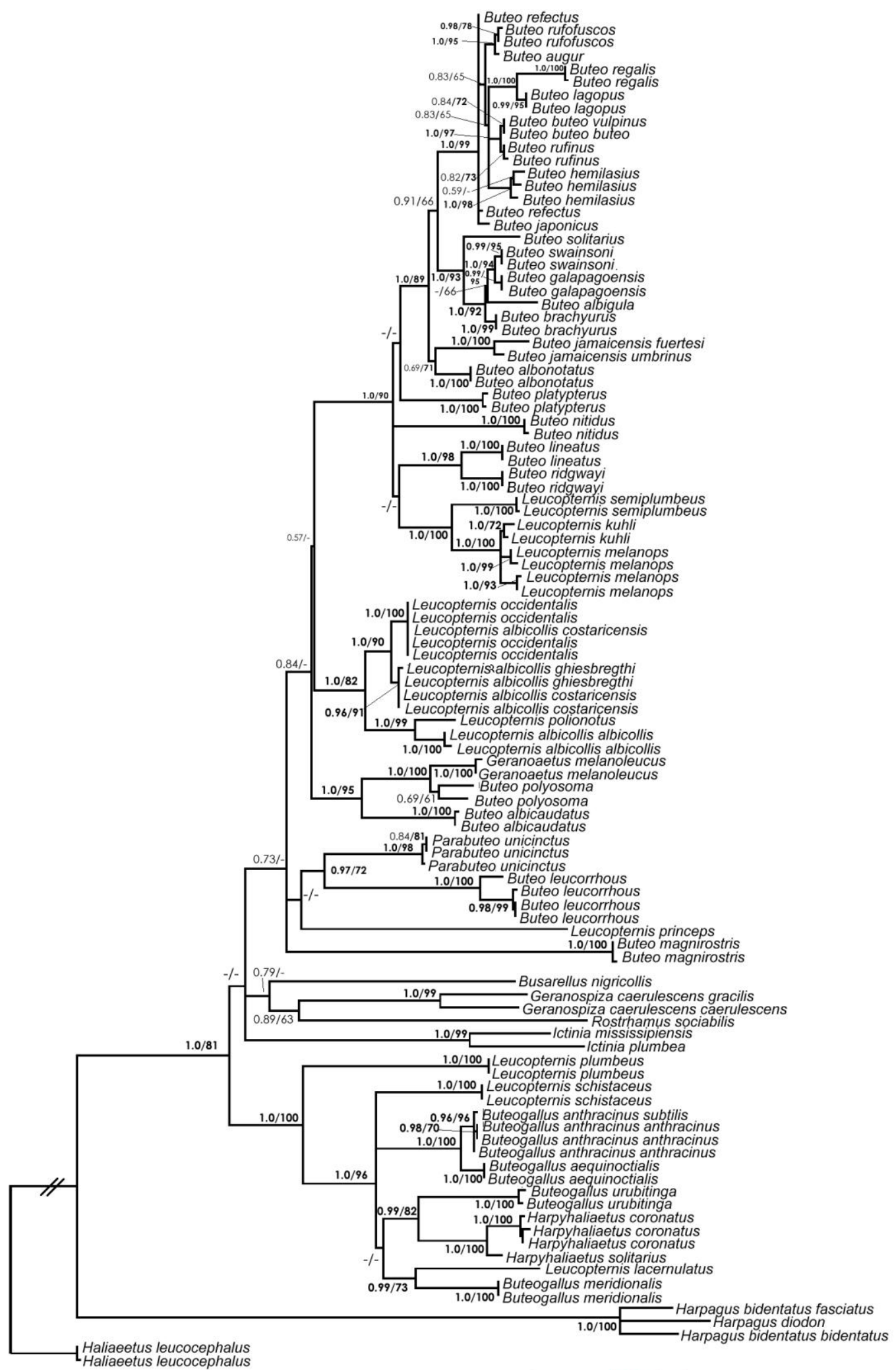

0.1 substituiçōes/sítio 
Anexo H. Topologia de máxima versomilhança (-In 4923.5243) da partição ND6. Números próximos aos nós correspondem a valores de probabilidades posteriores e bootstrap de máxima verossimilhança. Valores em negrito correspodem à probabilidades posteriores e bootstrap iguais ou maiores que 0,95 e 70, respectivamente.

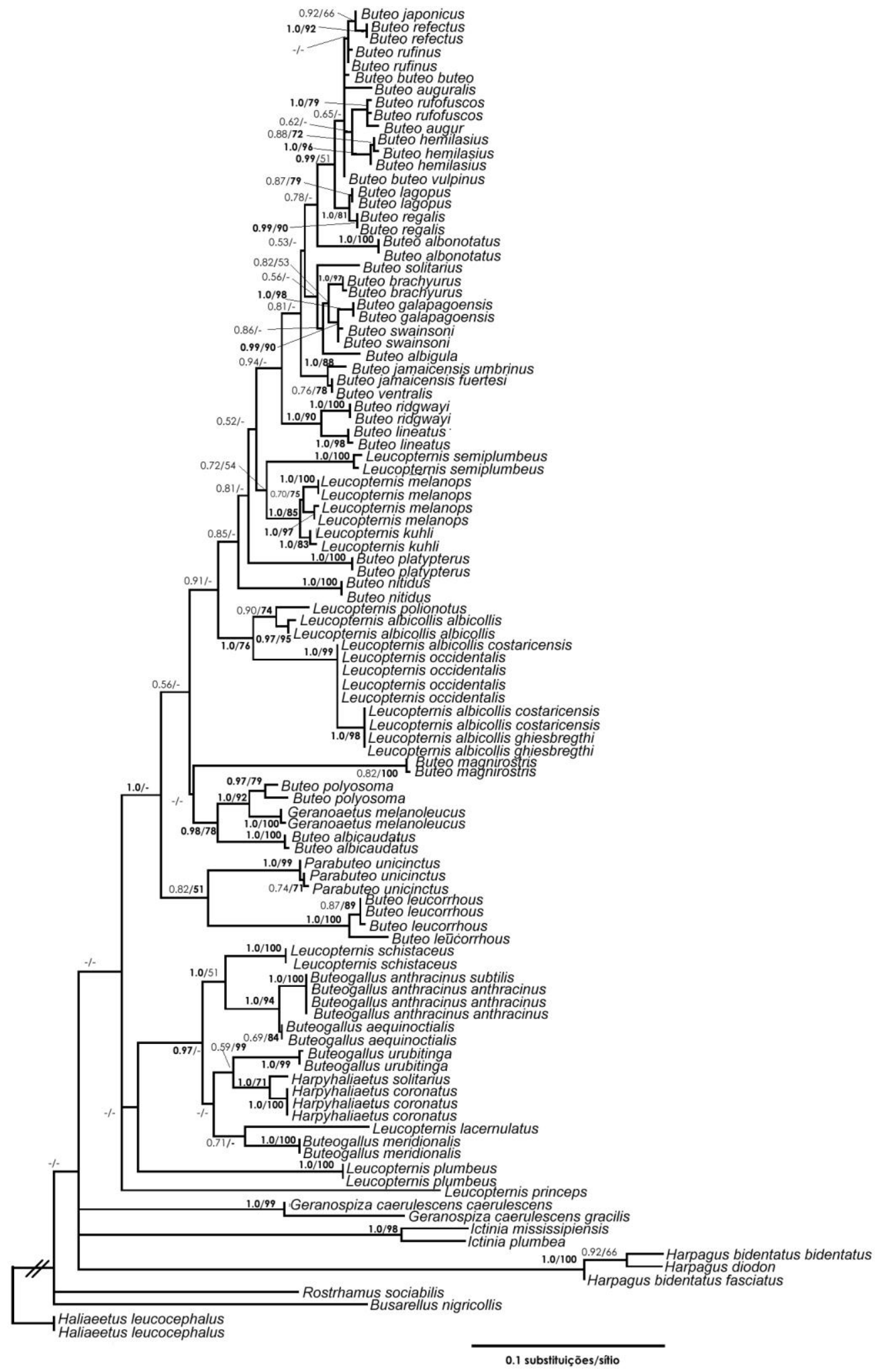


Anexo I. Topologia de máxima versomilhança (-In 8021.0139) da partição CYTB. Números próximos aos nós correspondem a valores de bootstrap de máxima verossimilhança e probabilidades posteriores. Valores em negrito correspodem a probabilidades posteriores e bootstrap iguais ou maiores que 0,95 e 70 , respectivamente.

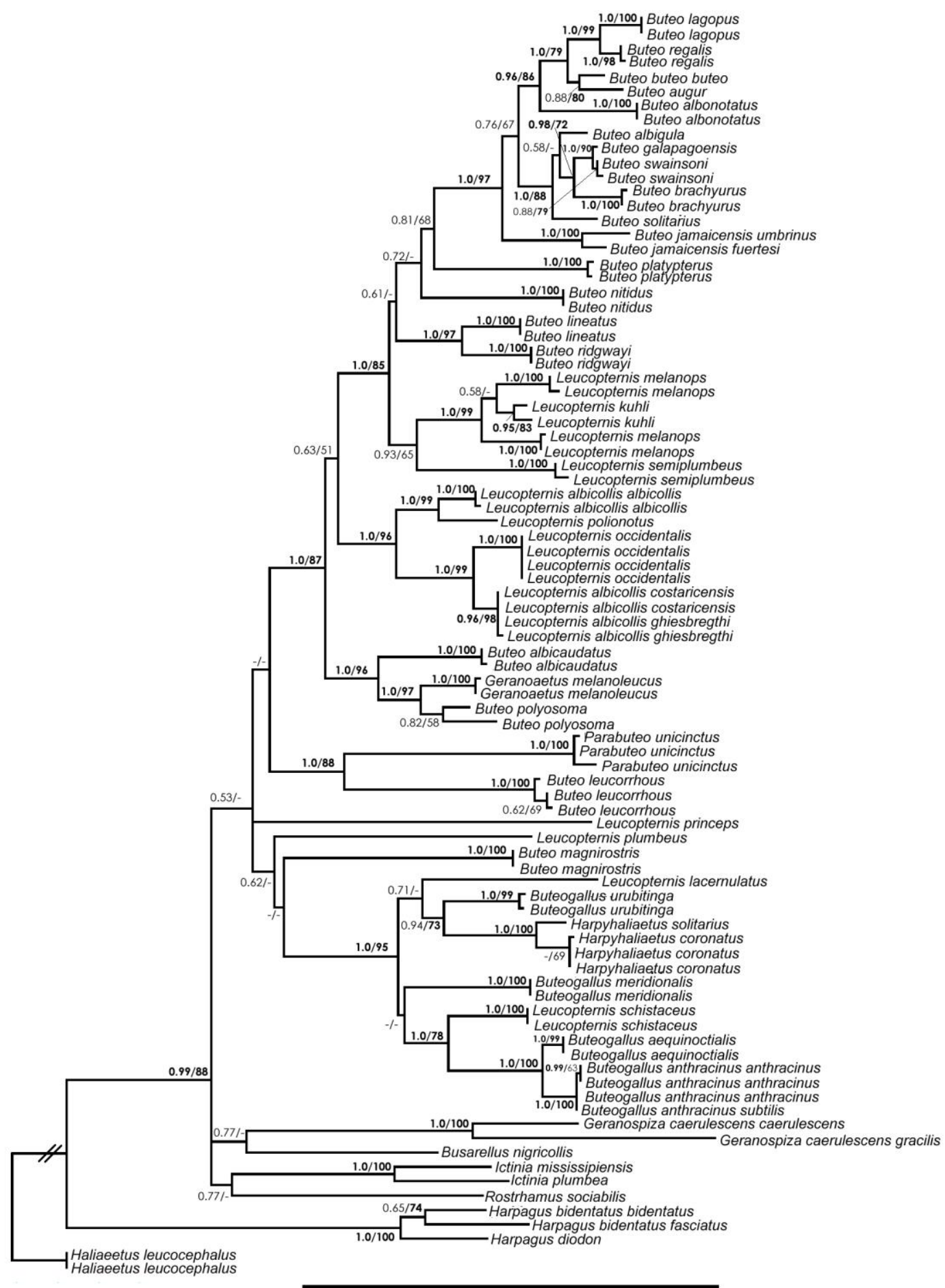

0.1 substituiçōes/sítio 
Anexo J. Topologia de máxima versomilhança (-In 8719.1160) da partição ND2. Números próximos aos nós correspondem à valores de bootstrap de probabilidades posteriores emáxima verossimilhança. Valores em negrito correspodem a probabilidades posteriores e bootstrap iguais ou maiores que 70 e 0,95, respectivamente.

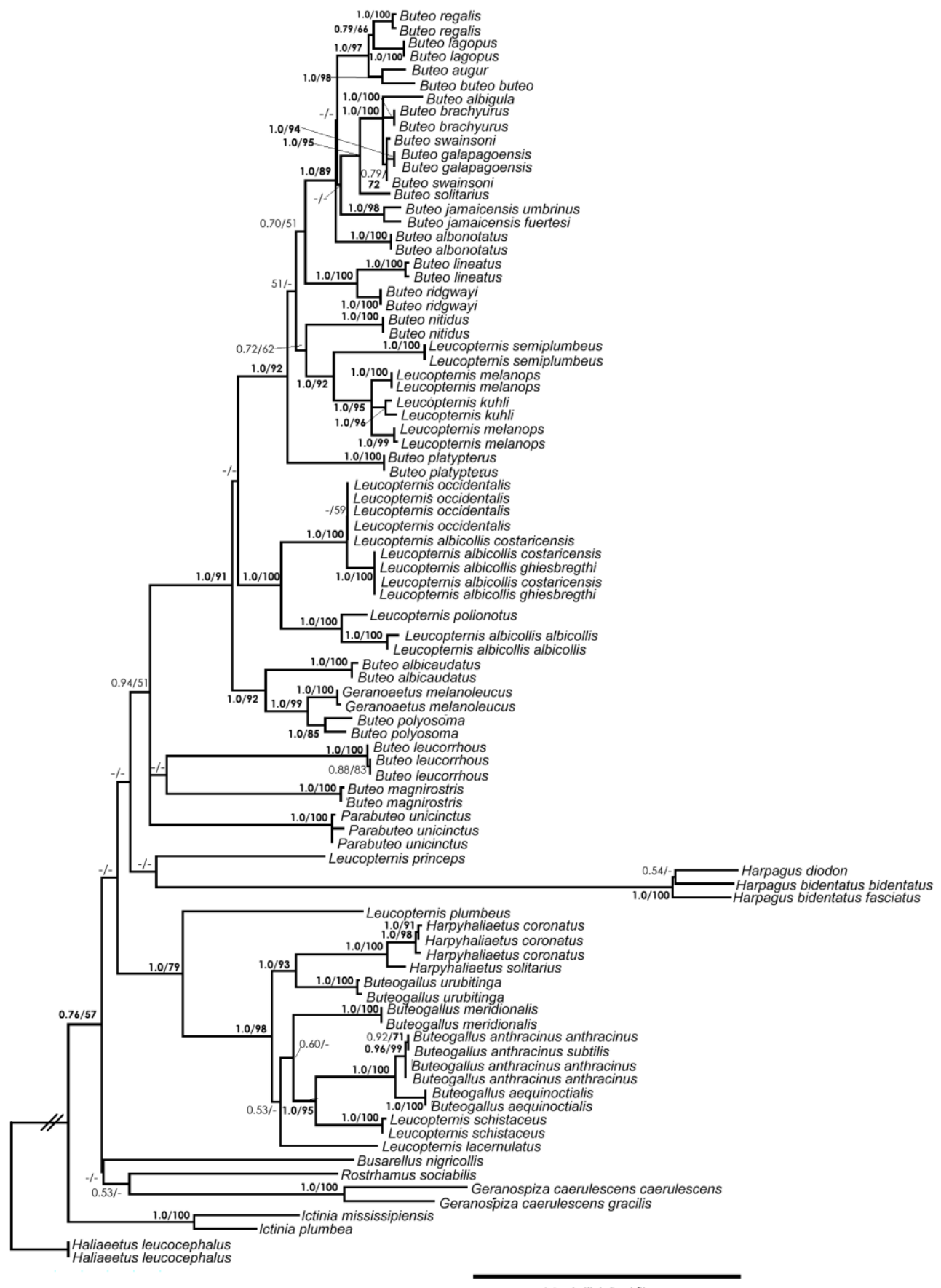


ANEXO K. Estimativas de tempo de divergência, desvio padrão (D.P.) e intervalo de confiança (I. C.) de 95\%, em milhões de anos, obtidos a partir do conjunto de dados mitocondrial combinados contendo hastes completas e parciais, respectivamente. A numeração segue a posicionamento indicado no Anexo L.

\begin{tabular}{|c|c|c|c|c|c|c|c|c|}
\hline \multirow{3}{*}{$\frac{\text { Nó }}{46}$} & \multicolumn{4}{|c|}{ Com hastes completas } & \multicolumn{4}{|c|}{ Com hastes parciais } \\
\hline & \multirow{2}{*}{$\frac{\text { Data }}{2,45}$} & \multirow{2}{*}{$\begin{array}{c}\text { D.P. } \\
0,66\end{array}$} & \multicolumn{2}{|c|}{ I.C. $95 \%$ (min-max) } & Data & \multirow{2}{*}{$\frac{\text { D.P. }}{0,67}$} & \multicolumn{2}{|c|}{ I.C. $95 \%$ (min-max) } \\
\hline & & & 1,41 & 3,99 & 2,46 & & 1,43 & 4,00 \\
\hline 47 & 4,04 & 1,05 & 2,41 & 6,45 & 4,00 & 1,03 & 2,38 & 6,43 \\
\hline 48 & 11,67 & 2,76 & 7,30 & 17,87 & 11,47 & 2,71 & 7,19 & 17,68 \\
\hline 49 & 7,84 & 1,94 & 4,84 & 12,27 & 7,79 & 1,92 & 4,77 & 12,20 \\
\hline 50 & 2,27 & 0,61 & 1,32 & 3,67 & 2,22 & 0,59 & 1,29 & 3,57 \\
\hline 51 & 4,32 & 1,09 & 2,61 & 6,84 & 4,35 & 1,10 & 2,63 & 6,89 \\
\hline 52 & 1,83 & 0,50 & 1,06 & 2,97 & 1,78 & 0,48 & 1,03 & 2,91 \\
\hline 53 & 3,97 & 1,01 & 2,42 & 6,32 & 3,95 & 1,01 & 2,38 & 6,25 \\
\hline 54 & 0,99 & 0,29 & 0,54 & 1,69 & 1,00 & 0,29 & 0,54 & 1,68 \\
\hline 55 & 3,39 & 0,87 & 2,04 & 5,39 & 3,37 & 0,86 & 2,05 & 5,36 \\
\hline 56 & 1,98 & 0,53 & 1,17 & 3,20 & 1,97 & 0,53 & 1,17 & 3,21 \\
\hline 57 & 1,15 & 0,31 & 0,66 & 1,87 & 1,14 & 0,31 & 0,65 & 1,85 \\
\hline 58 & 0,88 & 0,26 & 0,47 & 1,48 & 0,88 & 0,26 & 0,47 & 1,49 \\
\hline 59 & 1,46 & 0,39 & 0,85 & 2,35 & 1,46 & 0,39 & 0,85 & 2,36 \\
\hline 60 & 0,35 & 0,14 & 0,13 & 0,66 & 0,35 & 0,14 & 0,13 & 0,67 \\
\hline 61 & 0,94 & 0,27 & 0,53 & 1,56 & 0,92 & 0,26 & 0,51 & 1,53 \\
\hline 62 & 1,29 & 0,35 & 0,75 & 2,12 & 1,28 & 0,35 & 0,74 & 2,08 \\
\hline 63 & 2,02 & 0,53 & 1,20 & 3,25 & 2,04 & 0,53 & 1,20 & 3,27 \\
\hline 64 & 3,34 & 0,83 & 2,06 & 5,25 & 3,30 & 0,82 & 2,03 & 5,18 \\
\hline 65 & 4,64 & 1,14 & 2,88 & 7,26 & 4,65 & 1,14 & 2,88 & 7,32 \\
\hline 66 & 5,00 & 1,22 & 3,11 & 7,79 & 4,99 & 1,21 & 3,09 & 7,84 \\
\hline 67 & 6,94 & 1,69 & 4,29 & 10,80 & 6,92 & 1,68 & 4,30 & 10,83 \\
\hline 68 & 9,74 & 2,33 & 6,11 & 15,00 & 9,66 & 2,30 & 6,04 & 14,90 \\
\hline 69 & 10,52 & 2,50 & 6,63 & 16,09 & 10,44 & 2,47 & 6,55 & 16,02 \\
\hline 70 & 1,01 & 0,29 & 0,55 & 1,68 & 1,02 & 0,29 & 0,56 & 1,70 \\
\hline 71 & 3,80 & 0,96 & 2,28 & 5,94 & 3,82 & 0,97 & 2,29 & 6,04 \\
\hline 72 & 4,61 & 1,15 & 2,79 & 7,23 & 4,58 & 1,15 & 2,79 & 7,29 \\
\hline 73 & 0,91 & 0,27 & 0,48 & 1,54 & 0,90 & 0,27 & 0,48 & 1,52 \\
\hline 74 & 4,19 & 1,05 & 2,55 & 6,59 & 4,16 & 1,04 & 2,51 & 6,58 \\
\hline 75 & 5,49 & 1,34 & 3,39 & 8,50 & 5,43 & 1,32 & 3,35 & 8,49 \\
\hline 76 & 9,42 & 2,26 & 5,85 & 14,52 & 9,26 & 2,22 & 5,74 & 14,36 \\
\hline 77 & 11,29 & 2,66 & 7,12 & 17,26 & 11,18 & 2,63 & 7,01 & 17,14 \\
\hline 78 & 12,35 & 2,91 & 7,77 & 18,89 & 12,14 & 2,85 & 7,64 & 18,62 \\
\hline 79 & 13,49 & 3,17 & 8,48 & 20,63 & 13,19 & 3,10 & 8,27 & 20,13 \\
\hline 80 & 17,05 & 3,99 & 10,74 & 26,01 & 16,85 & 3,93 & 10,70 & 25,81 \\
\hline 81 & 18,32 & 4,27 & 11,57 & 27,91 & 18,17 & 4,24 & 11,50 & 27,78 \\
\hline 82 & 64,19 & 14,08 & 41,46 & 95,62 & 64,55 & 14,04 & 41,94 & 96,59 \\
\hline
\end{tabular}




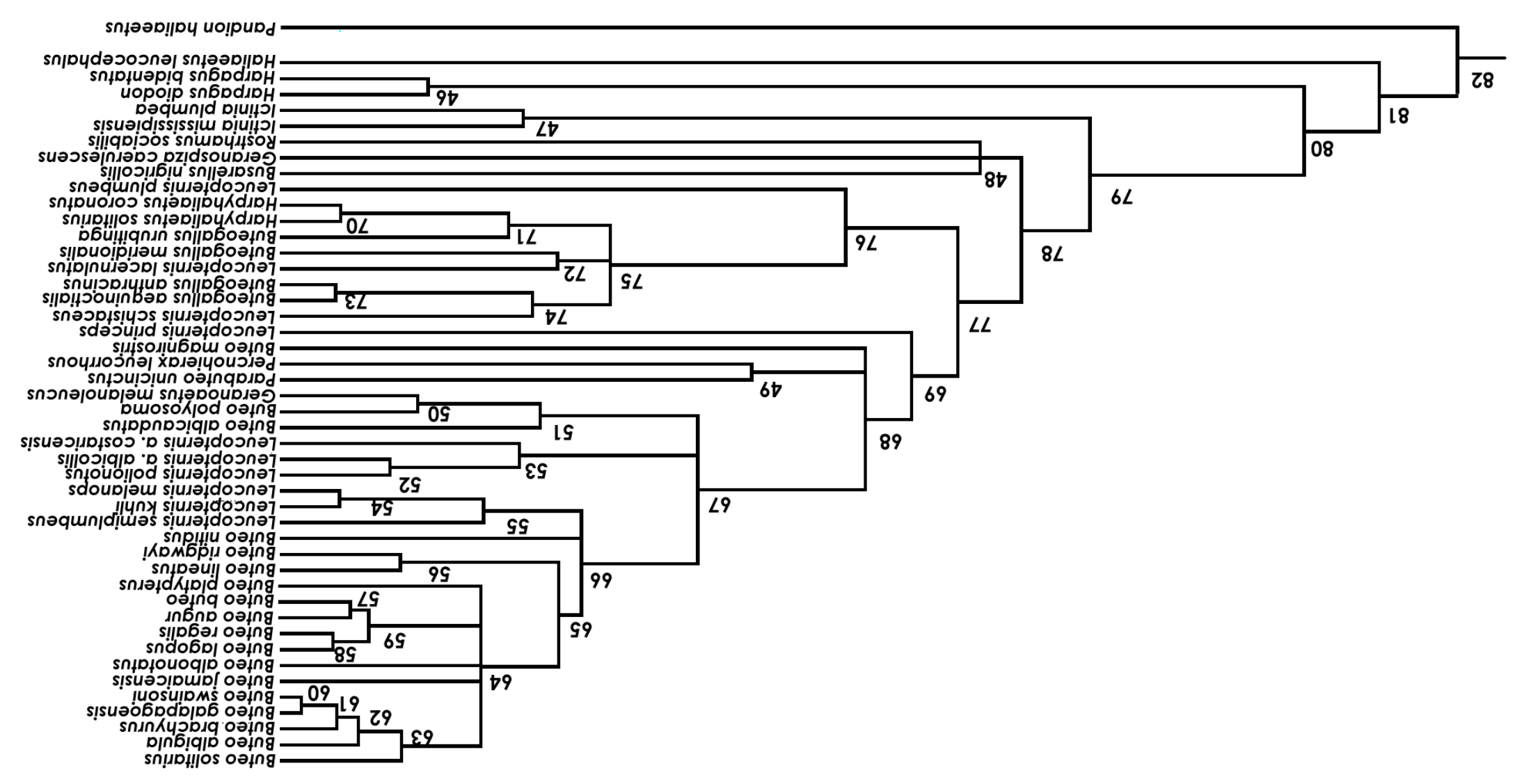


ANEXO M. Reconstrução de 17 passos do comportamento migratório, assumindo Buteo nitidus como a espécie mais basal do clado delimitado pelo nó B na figura 4 (capítulo 2).

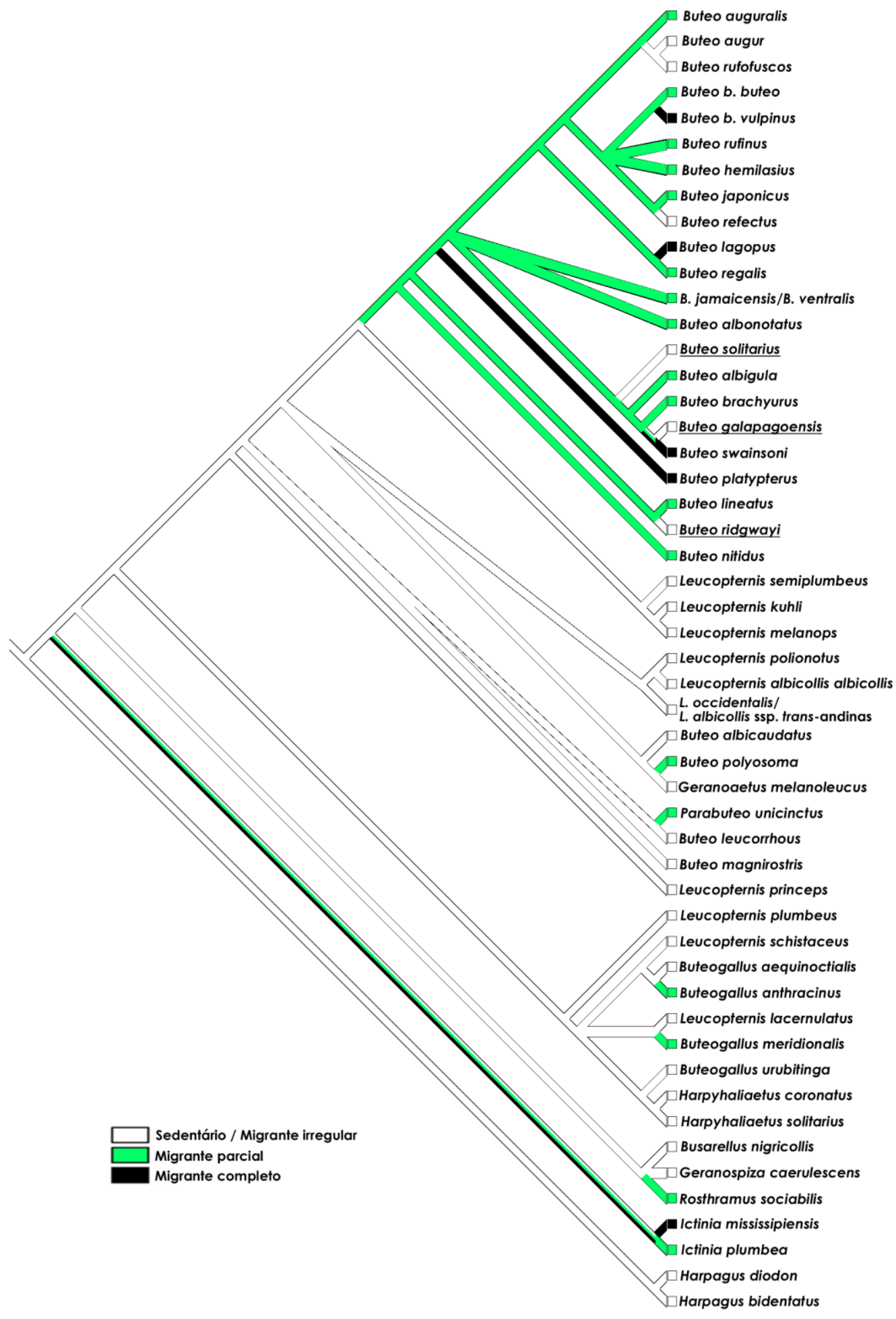


ANEXO N. Sequências utilizadas para a construção do modelo de estrutura secundária do rRNA 165 de Aves.

\begin{tabular}{|c|c|c|c|}
\hline Ordem & Família & Espécie & Número de acesso \\
\hline \multirow[t]{6}{*}{ STRUTHIONIFORMES } & Struthionidae & Struthio camelus & NC_002785 \\
\hline & Rheidae & Rhea americana & NC_000846 \\
\hline & & Pterocnemia pennata & NC_002783 \\
\hline & Casuariidae & Casuarius casuarius & NC_002778 \\
\hline & Dromaiidae & Dromaius novaehollandie & AF338711 \\
\hline & Apterygidae & Apteryx haastii & NC_002782 \\
\hline \multirow[t]{3}{*}{ DINORNITHIFORMES } & Dinornithidae & Dinornis giganteus & AY016013 \\
\hline & Emeidae & Emeus crassus & AY016015 \\
\hline & & Anomalopteryx didiformis & NC_002779 \\
\hline \multirow[t]{2}{*}{ TINAMIFORMES } & Tinamidae & Tinamus major & NC_002781 \\
\hline & & Eudromia elegans & NC_002772 \\
\hline \multirow[t]{3}{*}{ SPHENISCIFORMES } & Spheniscidae & Pygoscelis adeliae & AF173573 \\
\hline & & Eudyptes chrysocome & NC_008138 \\
\hline & & Eudyptula minor & NC_004538 \\
\hline \multirow[t]{3}{*}{ GAVIIFORMES } & Gaviidae & Gavia stellata & NC_007007 \\
\hline & & Gavia pacifica & NC_008139 \\
\hline & & Gavia immer & AF173577 \\
\hline \multirow[t]{3}{*}{ PODICIPEDIFORMES } & Podicipedidae & Podiceps cristatus & NC_008140 \\
\hline & & Podiceps auritus & AF173567 \\
\hline & & Aechmophorus occidentalis & AF339361 \\
\hline \multirow[t]{3}{*}{ PROCELLARIIFORMES } & Diomedeidae & Diomedea melanophris & NC_007172 \\
\hline & Procellariidae & Pterodroma brevirostris & NC_007174 \\
\hline & & Puffinus gravis & AF173572 \\
\hline \multirow[t]{6}{*}{ PELECANIFORMES } & Phaethontidae & Phaethon aethereus & AF173592 \\
\hline & & Phaethon rubricauda & NC_007979 \\
\hline & Pelecanidae & Pelecanus occidentalis & AF173570 \\
\hline & Sulidae & Sula nebouxii & AF173579 \\
\hline & Phalacrocoracidae & Phalacrocorax brasilianus & AF173580 \\
\hline & Fregatidae & Fregata magnificens & AF173576 \\
\hline \multirow[t]{9}{*}{ CICONIIFORMES } & Ardeidae & Ardea novaehollandiae & NC_008551 \\
\hline & & Nycticorax nycticorax & AF339358 \\
\hline & Scopidae & Scopus umbretta & AF339360 \\
\hline & Ciconiidae & Ciconia nigra & AF173571 \\
\hline & & Ciconia ciconia & NC_002197 \\
\hline & & Ciconia boyciana & NC_002196 \\
\hline & Balaenicipitidae & Balaeniceps rex & AF173569 \\
\hline & Threskiornithidae & Nipponia nippon & NC_008132 \\
\hline & & Platalea alba & AF339359 \\
\hline PHOENICOPTERIFORMES & Phoenicopteridae & Phoenicopterus ruber & AF173568 \\
\hline \multirow[t]{5}{*}{ ANSERIFORMES } & Anatidae & Anseranas semipalmata & NC_005933 \\
\hline & & Cygnus columbianus & NC_007691 \\
\hline & & Anser albifrons & NC_004539 \\
\hline & & Branta canadensis & NC_007011 \\
\hline & & Aythya americana & NC_000877 \\
\hline
\end{tabular}


Continuação do Anexo N.

\begin{tabular}{|c|c|c|c|}
\hline Ordem & Família & Espécie & Número de acesso \\
\hline \multirow[t]{3}{*}{ CATHARTIFORMES } & Cathartidae & Cathartes aura & NC_007628 \\
\hline & & Gymnogyps californianus & AF 173574 \\
\hline & & Vultur gryphus & AF173575 \\
\hline \multirow[t]{8}{*}{ FALCONIFORMES } & Pandionidae & Pandion haliaetus & NC_008550 \\
\hline & Accipitridae & Neophron percnopterus & AF173581 \\
\hline & & Buteo buteo & NC_003128 \\
\hline & & Spizaetus alboniger & NC_007599 \\
\hline & & Spizaetus nipalensis & NC_007598 \\
\hline & Falconidae & Micrastur gilvicollis & NC_008548 \\
\hline & & Falco peregrinus & NC_000878 \\
\hline & & Falco sparverius & NC_008547 \\
\hline \multirow[t]{9}{*}{ GALLIFORMES } & Megapodiidae & Alectura lathami & NC_007227 \\
\hline & Cracidae & Ortalis guttata & AF 173561 \\
\hline & Phasianidae & Coturnix japonica & NC_003408 \\
\hline & & Coturnix chinensis & NC_004575 \\
\hline & & Gallus gallus & NC_001323 \\
\hline & & Gallus gallus spadiceus & NC_007235 \\
\hline & & Gallus sonneratii & NC_007240 \\
\hline & & Gallus lafayettei & NC_007239 \\
\hline & Numididae & Numida meleagris & NC_006382 \\
\hline OPISTHOCOMIFORMES & Opisthocomidae & Opisthocomus hoazin & AF173587 \\
\hline \multirow[t]{2}{*}{ GRUIFORMES } & Turnicidae & Turnix sylvatica & AF173588 \\
\hline & Gruidae & Grus canadensis & AF173564 \\
\hline \multirow[t]{21}{*}{ CHARADRIIFORMES } & Jacanidae & Jacana jacana & DQ385290 \\
\hline & Rostratulidae & Nycticryphes semicollaris & DQ385291 \\
\hline & Haematopodidae & Haematopus ater & NC_003713 \\
\hline & Recurvirostridae & Himantopus mexicanus & DQ385285 \\
\hline & Burhinidae & Burhinus magnirostris & DQ385287 \\
\hline & Glareolidae & Cursorius temminckii & DQ385294 \\
\hline & Charadriidae & Charadrius semipalmatus & AF173565 \\
\hline & & Charadrius vociferus & DQ385286 \\
\hline & & Pluvianellus socialis & DQ385288 \\
\hline & Scolopacidae & Arenaria interpres & NC_003712 \\
\hline & Pedionomidae & Pedionomus torquatus & DQ385293 \\
\hline & Thinocoridae & Attagis gayi & DQ385292 \\
\hline & Chionidae & Chionis minor & DQ385289 \\
\hline & Stercorariidae & Catharacta skua & DQ385295 \\
\hline & Laridae & Larus dominicanus & NC_007006 \\
\hline & & Larus glaucoides & AF173566 \\
\hline & & Rissa tridactyla & DQ385297 \\
\hline & Sternidae & Sterna bengalensis & DQ385299 \\
\hline & Rynchopidae & Rynchops niger & DQ385298 \\
\hline & Alcidae & Synthliboramphus antiquus & NC_007978 \\
\hline & & Fratercula arctica & DQ385296 \\
\hline PTEROCLIFORMES & Pteroclidae & Pterocles namaqua & DQ385284 \\
\hline COLUMBIFORMES & Columbidae & Columba livia & AF173585 \\
\hline \multirow[t]{2}{*}{ PSITTACIFORMES } & Psittacidae & Strigops habroptilus & NC_005931 \\
\hline & & Melopsittacus undulatus & NC_009134 \\
\hline
\end{tabular}


Continuação do Anexo N.

\begin{tabular}{|c|c|c|c|}
\hline Ordem & Família & Espécie & Número de acesso \\
\hline \multirow[t]{3}{*}{ CUCULIFORMES } & Cuculidae & Cuculus pallidus & AF173583 \\
\hline & & Coccyzus americanus & AF173582 \\
\hline & & Crotophaga ani & AF173584 \\
\hline \multirow[t]{2}{*}{ STRIGIFORMES } & Strigidae & Bubo virginianus & AF173593 \\
\hline & & Ninox novaeseelandiae & NC_005932 \\
\hline CAPRIMULGIFORMES & Caprimulgidae & Chordeiles acutipennis & AF173590 \\
\hline \multirow[t]{3}{*}{ APODIFORMES } & Apodidae & Apus apus & NC_008540 \\
\hline & & Apus affinus & AF173586 \\
\hline & Trochilidae & Anthracothorax nigricollis & AF173598 \\
\hline COLIIFORMES & Coliidae & Urocolius macrourus & AF173589 \\
\hline TROGONIFORMES & Trogonidae & Trogon collaris & AF173563 \\
\hline \multirow[t]{3}{*}{ CORACIIFORMES } & Coraciidae & Coracias caudata & AF173596 \\
\hline & Upupidae & Upupa epops & AF173597 \\
\hline & Bucerotidae & Tockus nasutus & AF173595 \\
\hline GALBULIFORMES & Galbulidae & Galbula pastazae & AF173594 \\
\hline \multirow[t]{3}{*}{ PICIFORMES } & Ramphastidae & Pteroglossus azara & NC_008549 \\
\hline & Picidae & Picoides pubescens & AF173562 \\
\hline & & Dryocopus pileatus & NC_008546 \\
\hline \multirow[t]{8}{*}{ PASSERIFORMES } & Eurylaimidae & Smithornis sharpei & NC_000879 \\
\hline & Tyrannidae & Cnemotriccus fuscatus & NC_007975 \\
\hline & & Tyrannus tyrannus & AF173600 \\
\hline & Menuridae & Menura novaehollandiae & NC_007883 \\
\hline & Turdidae & Turdus migratorius & AF173599 \\
\hline & Corvidae & Corvus frugilegus & NC_002069 \\
\hline & Estrildidae & Taeniopygia guttata & NC_007897 \\
\hline & Viduidae & Vidua chalybeata & NC_000880 \\
\hline
\end{tabular}


Anexo O. Lista completa de sítios contendo exemplos de substituições compensatórias, e sítios e hastes presentes no modelo de mamíferos (Burk et al. 2002) mas não incluídos no modelo de aves. A numeração segue o modelo de mamíferos.

\section{Domínio I (Hastes 1-4)}

\section{Haste 1}

Não há exemplos de substituição compensatória nesta haste.

\section{Haste 2}

2-1: Posição presente no modelo de mamíferos, mas não incluída no modelo de aves. 2-3: Evidência de substituição compensatória em Pygoscelis adeliae, Eudyptes chrysocome, Eudyptula minor, Phalacrocorax brasilianus, Scopus umbretta, Trogon collaris.

\section{Haste 3}

3-2: Não há exemplos de substituição compensatória entre aves, o que no entanto pode ser observado quando o alinhamento de aves é comparado à seqüências de espécies de mamíferos (e.g Ornitorhynchus anatinus).

\section{Haste 4}

4-1: Não há exemplos de substituição compensatória entre aves, o que no entanto pode ser observado quando o alinhamento de aves é comparado à seqüências de espécies de mamíferos (e.g Hydrochaeris hydrochaeris, Oryctolagus cuniculus).

4-2: Não há exemplos de substituição compensatória entre aves, o que no entanto pode ser observado quando o alinhamento de aves é comparado à seqüências de espécies de mamíferos (e.g. Homo sapiens, Loxodonta africana, Ornitorhynchus anatinus).

\section{Domínio II (Hastes 5-21) Haste 5}

5-2: Evidência de substituição compensatória em Strigops habroptilus, Melopsittacus undulatus, Ninox novaeseelandiae, Chordeiles acutipennis, Menura novaehollandiae, Turdus migratorius, Corvus frugilegus, Taeniopygia guttata, Vidua chalybeata .

5-3: Evidência de substituição compensatória em Urocolius macrourus, Pteroglossus azara, Picoides pubescens, Dryocopus pileatus.

5-6: Evidência de substituição compensatória em Pterocles namaqua.

Haste 6

6-1: Posição presente no modelo de mamíferos, mas não incluída no modelo de aves. 6-3: Evidência de substituição compensatória em Anseranas semipalmata, Pterocles namaqua.

6-4: Evidência de substituição compensatória em Anseranas semipalmata, Melopsittacus undulatus, Urocolius macrourus.

\section{Haste 7}

7-3: Evidência de substituição compensatória em Casuarius casuarius, Dromaius novaehollandie, Dinornis giganteus, Emeus crassus, Anomalopteryx didiformis, Tinamus major, Sula nebouxii, Ardea novaehollandiae, Anseranas semipalmata, Cygnus columbianus, Anser albifrons, Branta canadensis, Aythya americana, Micrastur gilvicollis, Falco peregrinus, Falco sparverius, Alectura lathami, Coturnix japonica, Coturnix chinensis, Gallus gallus, Gallus gallus spadiceus, Gallus sonneratii, Gallus lafayettei, Numida meleagris, Grus canadensis, Jacana jacana, Nycticryphes semicollaris, Burhinus magnirostris, Pluvianellus socialis, Pedionomus torquatus, Chionis minor, Columba livia, Melopsittacus undulatus, Bubo virginianus, Ninox novaeseelandiae, Coracias caudata, Upupa epops, Pteroglossus azara, Dryocopus pileatus, Tyrannus tyrannus, Menura novaehollandiae. 


\section{Continuação do Anexo 0.}

\section{Haste 8}

8-4: Evidência de substituição compensatória em Pandion haliaetus, Grus canadensis, Jacana jacana, Nycticryphes semicollaris, Pedionomus torquatus, Attagis gayi, Upupa epops.

8-5: Evidência de substituição compensatória em Tinamus major, Eudyptes chrysocome, Eudyptula minor, Gavia stellata, Gavia pacifica, Gavia immer, Ciconia ciconia, Ciconia boyciana, Nipponia nippon, Platalea alba, Anseranas semipalmata, Micrastur gilvicollis, Turnix sylvatica, Jacana jacana, Charadrius vociferus, Chionis minor, Galbula pastazae, Tyrannus tyrannus.

8-6: Evidência de substituição compensatória em Pygoscelis adeliae, Eudyptes chrysocome, Eudyptula minor, Gavia stellata, Gavia pacifica, Gavia immer, Podiceps cristatus, Podiceps auritus, Aechmophorus occidentalis, Ciconia nigra, Ciconia ciconia, Ciconia boyciana, Pandion haliaetus, Turnix sylvatica, Arenaria interpres, Chionis minor, Bubo virginianus, Ninox novaeseelandiae, Chordeiles acutipennis, Pteroglossus azara, Cnemotriccus fuscatus. 8-7: Evidência de substituição compensatória em Turnix sylvatica, Tockus nasutus.

\section{Haste 9}

9-5: Evidência de substituição compensatória em Neophron percnopterus, Spizaetus alboniger, Spizaetus nipalensis, Pterocles namaqua, Trogon collaris, Taeniopygia guttata.

9-6: Posição presente no modelo de mamíferos, mas não incluída no modelo de aves.

9-7: Evidência de substituição compensatória em Dinornis giganteus, Emeus crassus, Anomalopteryx didiformis, Eudromia elegans, Diomedea melanophris, Cathartes aura, Gymnogyps californianus, Vultur gryphus, Pandion haliaetus, Buteo buteo, Coturnix japonica, Coturnix chinensis, Gallus gallus, Gallus gallus spadiceus, Gallus sonneratii, Gallus lafayettei, Numida meleagris, Opisthocomus hoazin, Turnix sylvatica, Grus canadensis, Jacana jacana, Nycticryphes semicollaris, Burhinus magnirostris, Cursorius temminckii, Charadrius semipalmatus, Charadrius vociferus, Pedionomus torquatus, Attagis gayi, Catharacta skua, Rissa tridactyla, Sterna bengalensis, Synthliboramphus antiquus, Fratercula arctica, Pterocles namaqua, Coccyzus americanus, Bubo virginianus, Tockus nasutus, Galbula pastazae, Dryocopus pileatus, Corvus frugilegus.

9-8: Evidência de substituição compensatória em Buteo buteo, Spizaetus alboniger, Spizaetus nipalensis, Corvus frugilegus.

9-9: Evidência de substituição compensatória em Eudromia elegans, Scopus umbretta, Nipponia nippon, Coturnix japonica, Numida meleagris, Arenaria interpres, Cnemotriccus fuscatus, Tyrannus tyrannus.

9-10: Evidência de substituição compensatória em Phalacrocorax brasilianus, Ardea novaehollandiae, Nycticorax nycticorax, Neophron percnopterus, Buteo buteo, Spizaetus alboniger, Spizaetus nipalensis, Ortalis guttata, Bubo virginianus, Urocolius macrourus.

9-11: Evidência de substituição compensatória em Pterodroma brevirostris, Puffinus gravis, Tyrannus tyrannus.

\section{Haste 10}

10-1: Evidência de substituição compensatória em Phaethon aethereus, Phaethon rubricauda. 10-2: Evidência de substituição compensatória em Cygnus columbianus, Strigops habroptilus. 10-3: Evidência de substituição compensatória em Alectura lathami, Ortalis guttata, Urocolius macrourus.

\section{Haste 11}

11-4: Evidência de substituição compensatória em Haematopus hater and Pluvianellus socialis.

\section{Haste 12}

Não há exemplos de substituição compensatória nesta haste 


\section{Continuação do Anexo 0.}

\section{Haste 13}

13-1: Evidência de substituição compensatória em Puffinus gravis, Cygnus columbianus, Anser albifrons, Branta canadensis, Aythya americana, Cathartes aura, Micrastur gilvicollis, Falco peregrinus, Falco sparverius, Coturnix japonica, Coturnix chinensis, Gallus gallus, Gallus gallus spadiceus, Gallus sonneratii, Gallus lafayettei, Numida meleagris, Catharacta skua, Columba livia, Trogon collaris.

13-2: Evidência de substituição compensatória em Dinornis giganteus, Emeus crassus, Anomalopteryx didiformis, Sterna bengalensis, Upupa epops.

13-3: Evidência de substituição compensatória em Apteryx haastii.

13-4: Evidência de substituição compensatória em Ardea novaehollandiae, Nycticorax nycticorax, Ciconia nigra, Ciconia ciconia, Ciconia boyciana, Attagis gayi, Anthracothorax nigricollis, Upupa epops.

13-5: Evidência de substituição compensatória em Upupa epops, Cnemotriccus fuscatus, Tyrannus tyrannus.

13-6: Evidência de substituição compensatória em Tinamus major, Podiceps cristatus, Podiceps auritus, Aechmophorus occidentalis, Micrastur gilvicollis, Falco peregrinus, Alectura lathami, Ortalis guttata, Coturnix japonica, Coturnix chinensis, Numida meleagris, Jacana jacana, Burhinus magnirostris, Charadrius semipalmatus, Charadrius vociferus, Crotophaga ani, Upupa epops, Galbula pastazae, Smithornis sharpei.

\section{Haste 14}

14-2: Evidência de substituição compensatória em Upupa epops.

14-3: Evidência de substituição compensatória em Upupa epops.

\section{Haste 15}

15-1: Evidência de substituição compensatória em Apteryx haastii, Anseranas semipalmata, Sterna bengalensis, Picoides pubescens, Dryocopus pileatus.

15-2: Evidência de substituição compensatória em Struthio camelus, Rhea americana, Pterocnemia pennata, Casuarius casuarius, Dromaius novaehollandie, Apteryx haastii, Dinornis giganteus, Emeus crassus, Anomalopteryx didiformis, Tinamus major, Eudromia elegans, Sterna bengalensis, Coccyzus americanus, Trogon collaris, Pteroglossus azara, Picoides pubescens, Dryocopus pileatus.

15-3: Evidência de substituição compensatória em Attagis gayi, Cnemotriccus fuscatus.

15-4: Evidência de substituição compensatória em Spizaetus alboniger, Spizaetus nipalensis, Falco peregrinus, Falco sparverius, Numida meleagris, Charadrius semipalmatus, Charadrius vociferus, Attagis gayi, Melopsittacus undulatus, Bubo virginianus, Ninox novaeseelandiae, Anthracothorax nigricollis, Menura novaehollandiae.

15-5: Evidência de substituição compensatória em Struthio camelus, Apteryx haastii, Dinornis giganteus, Emeus crassus, Anomalopteryx didiformis, Tinamus major, Eudromia elegans, Pelecanus occidentalis, Sula nebouxii, Phalacrocorax brasilianus, Ardea novaehollandiae, Nycticorax nycticorax, Ciconia nigra, Ciconia ciconia, Ciconia boyciana, Balaeniceps rex, Anseranas semipalmata, Gallus gallus, Gallus gallus spadiceus, Gallus sonneratii, Gallus lafayettei, Numida meleagris, Turnix sylvatica, Haematopus ater, Himantopus mexicanus, Burhinus magnirostris, Cursorius temminckii, Larus dominicanus, Larus glaucoides, Rissa tridactyla, Sterna bengalensis, Rynchops niger, Synthliboramphus antiquus, Fratercula arctica, Columba livia, Strigops habroptilus, Bubo virginianus, Ninox novaeseelandiae, Chordeiles acutipennis, Anthracothorax nigricollis, Coracias caudata, Tockus nasutus, Menura novaehollandiae. 


\section{Continuação do Anexo O.}

\section{Haste 16}

16-1: Evidência de substituição compensatória em Turnix sylvatica.

16-3: Evidência de substituição compensatória em Cathartes aura, Gymnogyps californianus, Vultur gryphus, Alectura lathami, Ortalis guttata, Coturnix japonica, Coturnix chinensis, Gallus gallus, Gallus gallus spadiceus, Gallus sonneratii, Gallus lafayettei, Numida meleagris, Rynchops niger, Coracias caudata.

16-4: Evidência de substituição compensatória em Coturnix japonica, Coturnix chinensis, Gallus gallus, Gallus gallus spadiceus, Gallus sonneratii, Gallus lafayettei, Numida meleagris.

16-6: Evidência de substituição compensatória em Anseranas semipalmata, Cygnus columbianus, Anser albifrons, Branta canadensis, Aythya americana, Alectura lathami, Gallus gallus, Gallus gallus spadiceus, Gallus sonneratii, Gallus lafayettei.

16-9: Evidência de substituição compensatória em Eudyptula minor, Gavia stellata, Gavia pacifica, Gavia immer, Pterodroma brevirostris, Puffinus gravis, Pelecanus occidentalis, Sula nebouxii, Phalacrocorax brasilianus, Fregata magnificens, Scopus umbretta, Balaeniceps rex, Grus canadensis, Burhinus magnirostris, Pedionomus torquatus, Attagis gayi, Catharacta skua, Columba livia, Strigops habroptilus, Melopsittacus undulatus, Cuculus pallidus, Bubo virginianus, Ninox novaeseelandiae, Chordeiles acutipennis, Urocolius macrourus, Coracias caudata, Upupa epops, Picoides pubescens, Dryocopus pileatus, Smithornis sharpei.

\section{Haste 17}

17-1: Evidência de substituição compensatória em Smithornis sharpei.

17-2: Posição presente no modelo de mamíferos, mas não incluída no modelo de aves.

\section{Haste 18}

18-1: Posição presente no modelo de mamíferos, mas não incluída no modelo de aves. 18-2: Posição presente no modelo de mamíferos, mas não incluída no modelo de aves. 18-7: Evidência de substituição compensatória em Struthio camelus, Rhea americana, Pterocnemia pennata, Casuarius casuarius, Dromaius novaehollandie, Apteryx haastii, Dinornis giganteus, Emeus crassus, Anomalopteryx didiformis, Eudromia elegans.

\section{Haste 19}

Não há exemplos de substituição compensatória nesta haste

19-1: Posição presente no modelo de mamíferos, mas não incluída no modelo de aves.

\section{Haste 20}

20-1: Evidência de substituição compensatória em Cathartes aura, Gymnogyps californianus, vultur gryphus.

\section{Haste 21}

21-1: Posição presente no modelo de mamíferos, mas não incluída no modelo de aves. 21-2: Evidência de substituição compensatória em Cnemotriccus fuscatus, Tyrannus tyrannus. 21-5: Evidência de substituição compensatória em Galbula pastazae.

\section{Domínio III (Hastes 22-27) Haste 22}

22-2: Evidência de substituição compensatória em Struthio camelus, Dinornis giganteus, Emeus crassus, Anomalopteryx didiformis, Tinamus major, Eudromia elegans, Pygoscelis adeliae, Eudyptes chrysocome, Eudyptula minor, Gallus gallus, Gallus gallus spadiceus, Gallus sonneratii, Gallus lafayettei, Upupa epops.

Haste 23 - Esta haste está presente no modelo de mamíferos, mas não foi incluída no modelo de aves. 


\section{Continuação do Anexo 0.}

\section{Haste 24}

24-1: Evidência de substituição compensatória em Menura novaehollandiae, Turdus migratorius, Corvus frugilegus, Taeniopygia guttata, Vidua chalybeata.

24-3: Evidência de substituição compensatória em Alectura lathami, Trogon collaris, Galbula pastazae.

24-4: Evidência de substituição compensatória em Ortalis guttata, Coturnix japonica, Coturnix chinensis, Chionis minor, Smithornis sharpei.

Haste 25 - Esta haste está presente no modelo de mamíferos, mas não foi incluída no modelo de aves.

\section{Haste 26}

26-2: Evidência de substituição compensatória em Phalacrocorax brasilianus, Burhinus magnirostris, Ninox novaeseelandiae.

26-3: Evidência de substituição compensatória em Numida meleagris, Turnix sylvatica, Himantopus mexicanus, Burhinus magnirostris, Charadrius semipalmatus, Charadrius vociferus, Pedionomus torquatus, Pterocles namaqua, Galbula pastazae, Pteroglossus azara, Cnemotriccus fuscatus, Menura novaehollandiae, Turdus migratorius, Corvus frugilegus, Taeniopygia guttata, Vidua chalybeata.

\section{Haste 27}

Não há exemplos de substituição compensatória nesta haste.

\section{Domínio IV (Hastes 28-36) Haste 28}

28-2: Evidência de substituição compensatória em Cuculus pallidus.

28-3: Evidência de substituição compensatória em Neophron percnopterus, Buteo buteo, Spizaetus alboniger, Spizaetus nipalensis, Pteroglossus azara.

28-4: Evidência de substituição compensatória em Eudromia elegans, Phoenicopterus ruber, Ortalis guttata, Gallus gallus, Gallus gallus spadiceus, Gallus sonneratii, Gallus lafayettei, Strigops habroptilus, Upupa epops, Smithornis sharpei, Menura novaehollandiae, Turdus migratorius, Corvus frugilegus, Taeniopygia guttata, Vidua chalybeata.

28-5: Evidência de substituição compensatória em Coccyzus americanus.

28-6: Evidência de substituição compensatória em Strigops habroptilus, Coccyzus americanus, Ninox novaeseelandiae, Urocolius macrourus, Dryocopus pileatus.

28-7: Evidência de substituição compensatória em Gavia stellata, Gallus gallus, Gallus gallus spadiceus, Strigops habroptilus, Coccyzus americanus, Anthracothorax nigricollis.

28-8: Evidência de substituição compensatória em Struthio camelus, Casuarius casuarius, Dromaius novaehollandie, Dinornis giganteus, Emeus crassus, Anomalopteryx didiformis, Tinamus major, Eudromia elegans, Pygoscelis adeliae, Eudyptes chrysocome, Eudyptula minor, Gavia stellata, Gavia pacifica, Gavia immer, Podiceps cristatus, Podiceps auritus, Aechmophorus occidentalis, Pelecanus occidentalis, Ciconia nigra, Phoenicopterus ruber, Neophron percnopterus, Spizaetus alboniger, Spizaetus nipalensis, Alectura lathami, Coturnix japonica, Coturnix chinensis, Gallus gallus, Gallus gallus spadiceus, Gallus sonneratii, Gallus lafayettei, Charadrius semipalmatus, Charadrius vociferus, Strigops habroptilus, Melopsittacus undulatus, Coccyzus americanus, Crotophaga ani, Chordeiles acutipennis, Anthracothorax nigricollis, Upupa epops, Smithornis sharpei.

28-9: Evidência de substituição compensatória em Phaethon aethereus, Phaethon rubricauda, Fregata magnificens, Cygnus columbianus, Anser albifrons, Branta canadensis, Aythya americana, Alectura lathami, Ninox novaeseelandiae.

28-10: Evidência de substituição compensatória em Gavia pacifica, Gavia immer, Anseranas semipalmata, Ortalis guttata, Gallus gallus, Gallus gallus spadiceus, Gallus sonneratii, Gallus lafayettei, Pluvianellus socialis, Chionis minor, Rissa tridactyla, Rynchops niger, Urocolius macrourus, Tockus nasutus, Galbula pastazae, Pteroglossus azara, Picoides pubescens, Dryocopus pileatus. 


\section{Continuação do Anexo 0.}

\section{Haste 29}

29-1: Evidência de substituição compensatória em Apus apus, Apus affinus, Anthracothorax nigricollis, Smithornis sharpei.

29-2: Evidência de substituição compensatória em Rhea americana, Pterocnemia pennata, Apteryx haastii, Dinornis giganteus, Emeus crassus, Anomalopteryx didiformis, Sula nebouxii, Phalacrocorax brasilianus, Fregata magnificens, Ardea novaehollandiae, Nycticorax nycticorax, Ciconia nigra, Ciconia ciconia, Ciconia boyciana, Nipponia nippon, Platalea alba, Jacana jacana, Haematopus ater, Himantopus mexicanus, Cursorius temminckii, Charadrius semipalmatus, Charadrius vociferus, Sterna bengalensis, Urocolius macrourus, Dryocopus pileatus.

29-3: Evidência de substituição compensatória em Urocolius macrourus.

29-4: Evidência de substituição compensatória em Neophron percnopterus, Coturnix japonica, Coturnix chinensis, Gallus gallus, Gallus gallus spadiceus, Gallus sonneratii, Gallus lafayettei, Numida meleagris, Sterna bengalensis, Cuculus pallidus, Crotophaga ani.

29-5: Evidência de substituição compensatória em Charadrius semipalmatus, Charadrius vociferus.

\section{Haste 30}

Não há exemplos de substituição compensatória nesta haste.

\section{Haste 31}

31-3: Evidência de substituição compensatória em Phaethon aethereus, Phaethon rubricauda, Spizaetus alboniger, Spizaetus nipalensis, Smithornis sharpei.

31-4: Evidência de substituição compensatória em Falco peregrinus, Falco sparverius, Ninox novaeseelandiae, Smithornis sharpei, Cnemotriccus fuscatus.

31-5: Evidência de substituição compensatória em Cuculus pallidus, Coccyzus americanus, Crotophaga ani.

\section{Haste 32}

Não há exemplos de substituição compensatória nesta haste.

\section{Haste 33}

33-8: Evidência de substituição compensatória em Rynchops niger and Crotophaga ani.

\section{Haste 34}

34-4: Evidência de substituição compensatória em Upupa epops.

\section{Haste 35}

Não há exemplos de substituição compensatória nesta haste.

35-3: Posição presente no modelo de mamíferos, mas não incluída no modelo de aves.

\section{Haste 36}

36-4: Posição presente no modelo de mamíferos, mas não incluída no modelo de aves. 36-6: Evidência de substituição compensatória em Vidua chalybeata.

\section{Haste 37}

37-1: Evidência de substituição compensatória em Dinornis giganteus, Emeus crassus, Anomalopteryx didiformis, Fregata magnificens, Ciconia ciconia, Ciconia boyciana, Anseranas semipalmata, Cygnus columbianus, Anser albifrons, Branta canadensis, Gymnogyps californianus, Vultur gryphus, Alectura lathami, Opisthocomus hoazin, Jacana jacana, Arenaria 


\section{Continuação do Anexo 0.}

interpres, Attagis gayi, Strigops habroptilus, Melopsittacus undulatus, Bubo virginianus, Chordeiles acutipennis, Anthracothorax nigricollis, Urocolius macrourus, Trogon collaris, Upupa epops, Tockus nasutus, Galbula pastazae, Pteroglossus azara, Picoides pubescens, Dryocopus pileatus, Smithornis sharpei, Turdus migratorius, Corvus frugilegus, Taeniopygia guttata, Vidua chalybeata.

37-2: Evidência de substituição compensatória em Dryocopus pileatus.

37-3: Evidência de substituição compensatória em Apteryx haastii, Diomedea melanophris, Ardea novaehollandiae, Coturnix japonica, Coturnix chinensis, Gallus sonneratii, Strigops habroptilus, Anthracothorax nigricollis, Upupa epops, Dryocopus pileatus.

37-4: Evidência de substituição compensatória em Balaeniceps rex, Phoenicopterus ruber, Anseranas semipalmata, Cygnus columbianus, Anser albifrons, Aythya americana, Ortalis guttata, Coturnix japonica, Coturnix chinensis, Gallus gallus, Gallus gallus spadiceus, Gallus sonneratii, Gallus lafayettei, Numida meleagris, Rynchops niger, Melopsittacus undulatus, Anthracothorax nigricollis, Coracias caudata, Upupa epops, Picoides pubescens, Dryocopus pileatus, Smithornis sharpei.

37-5: Evidência de substituição compensatória em Smithornis sharpei.

Domínio V (Hastes 38-50)

Haste 38

38-3: Evidência de substituição compensatória em Cathartes aura, Neophron percnopterus, Melopsittacus undulatus, Bubo virginianus, Ninox novaeseelandiae, Chordeiles acutipennis.

\section{Haste 39}

39-5: Não há exemplos de substituição compensatória entre aves, o que no entanto pode ser observado quando o alinhamento de aves é comparado à seqüências de espécies de mamíferos (e.g Bos taurus, Homo sapiens, Loxodonta africana, Bradypus tridactylus, Mus domesticus, Hydrochaeris hydrochaeris, Oryctolagus cuniculus, Pteropus hypomelanus, Equus caballus).

39-9: Posição presente no modelo de mamíferos, mas não incluída no modelo de aves.

\section{Haste 40}

40-3: Evidência de substituição compensatória em Upupa epops.

40-5: Evidência de substituição compensatória em Struthio camelus, Tockus nasutus, Turdus migratorius, Taeniopygia guttata, Vidua chalybeata.

40-6: Posição presente no modelo de mamíferos, mas não incluída no modelo de aves. 40-7: Posição presente no modelo de mamíferos, mas não incluída no modelo de aves. 40-8: Posição presente no modelo de mamíferos, mas não incluída no modelo de aves. 40-9: Evidência de substituição compensatória em Ciconia nigra, Alectura lathami, Opisthocomus hoazin, Jacana jacana, Arenaria interpres, Catharacta skua, Rynchops niger, Columba livia, Strigops habroptilus, Melopsittacus undulatus, Ninox novaeseelandiae, Chordeiles acutipennis, Apus apus, Apus affinus, Anthracothorax nigricollis, Urocolius macrourus, Tockus nasutus, Picoides pubescens, Smithornis sharpei.

40-10: Evidência de substituição compensatória em Struthio camelus, Casuarius casuarius, Dromaius novaehollandie, Apteryx haastii, Dinornis giganteus, Emeus crassus, Anomalopteryx didiformis, Tinamus major, Eudromia elegans, Eudyptes chrysocome, Eudyptula minor, Cygnus columbianus, Anser albifrons, Spizaetus alboniger, Spizaetus nipalensis, Coturnix japonica, Coturnix chinensis, Gallus gallus, Gallus gallus spadiceus, Gallus sonneratii, Gallus lafayettei, Numida meleagris, Opisthocomus hoazin, Jacana jacana, Larus dominicanus, Larus glaucoides, Cuculus pallidus, Coccyzus americanus, Galbula pastazae, Dryocopus pileatus, Turdus migratorius, Taeniopygia guttata, Vidua chalybeata.

40-11: Evidência de substituição compensatória em Struthio camelus, Ciconia ciconia, Turnix sylvatica, Cuculus pallidus, Anthracothorax nigricollis.

40-12: Evidência de substituição compensatória em Rynchops niger, Trogon collaris. 


\section{Continuação do Anexo 0.}

\section{Haste 41}

41-3: Evidência de substituição compensatória em Apteryx haastii, Pteroglossus azara, Picoides pubescens, Dryocopus pileatus.

\section{Haste 42}

42-1: Evidência de substituição compensatória em Ninox novaeseelandiae, Pteroglossus azara, Picoides pubescens, Dryocopus pileatus.

\section{Haste 44}

44-2: Evidência de substituição compensatória em Opisthocomus hoazin, Urocolius macrourus. 44-4: Evidência de substituição compensatória em Podiceps cristatus, Podiceps auritus, Alectura lathami.

44-5: Posição presente no modelo de mamíferos, mas não incluída no modelo de aves.

\section{Haste 45}

45-3: Evidência de substituição compensatória em Gavia stellata, Gavia pacifica, Gavia immer, Catharacta skua, Cuculus pallidus, Coccyzus americanus, Crotophaga ani, Apus apus, Apus affinus, Anthracothorax nigricollis, Galbula pastazae, Pteroglossus azara, Picoides pubescens, Dryocopus pileatus, Smithornis sharpei.

\section{Haste 46}

46-7: Evidência de substituição compensatória em Pygoscelis adeliae, Eudyptes chrysocome, Eudyptula minor, Podiceps cristatus, Podiceps auritus, Aechmophorus occidentalis, Phalacrocorax brasilianus, Anseranas semipalmata, Cygnus columbianus, Anser albifrons, Branta canadensis, Aythya americana, Pandion haliaetus, Spizaetus alboniger, Spizaetus nipalensis, Alectura lathami, Ortalis guttata, Grus canadensis, Jacana jacana, Nycticryphes semicollaris, Himantopus mexicanus, Pedionomus torquatus, Catharacta skua, Pterocles namaqua, Columba livia, Bubo virginianus, Chordeiles acutipennis, Anthracothorax nigricollis, Urocolius macrourus, Trogon collaris, Upupa epops, Tockus nasutus, Pteroglossus azara, Picoides pubescens, Dryocopus pileatus.

46-9: Evidência de substituição compensatória em Buteo buteo, Spizaetus alboniger, Spizaetus nipalensis, Falco peregrinus, Falco sparverius .

46-10: Evidência de substituição compensatória em Ciconia nigra, Ciconia ciconia, Ciconia boyciana, Cygnus columbianus, Anser albifrons, Branta canadensis, Aythya americana, Gymnogyps californianus, Vultur gryphus, Pandion haliaetus, Neophron percnopterus, Buteo buteo, Spizaetus alboniger, Spizaetus nipalensis, Falco peregrinus, Falco sparverius, Opisthocomus hoazin, Strigops habroptilus, Apus apus, Apus affinus, Coracias caudata, Upupa epops, Tockus nasutus, Galbula pastazae, Cnemotriccus fuscatus, Tyrannus tyrannus, Turdus migratorius.

46-11: Posição presente no modelo de mamíferos, mas não incluída no modelo de aves.

\section{Haste 47}

47-8: Não há exemplos de substituição compensatória entre aves, o que no entanto pode ser observado quando o alinhamento de aves é comparado à seqüências de espécies de mamíferos (e.g Equus).

47-11: Não há exemplos de substituição compensatória entre aves, o que no entanto pode ser observado quando o alinhamento de aves é comparado à seqüências de espécies de mamíferos (e.g Tayassu tajacu, Pseudocheirus herbertensis).

\section{Haste 48}

48-3: Evidência de substituição compensatória em Charadrius semipalmatus, Charadrius vociferus. 


\section{Continuação do Anexo 0.}

48-4: Evidência de substituição compensatória em Diomedea melanophris, Pterodroma brevirostris, Puffinus gravis, Ciconia nigra, Ciconia ciconia, Ciconia boyciana, Strigops habroptilus, Melopsittacus undulatus, Urocolius macrourus, Smithornis sharpei, Cnemotriccus fuscatus, Tyrannus tyrannus, Menura novaehollandiae, Turdus migratorius, Corvus frugilegus, Taeniopygia guttata, Vidua chalybeata.

48-5: Evidência de substituição compensatória em Smithornis sharpei, Vidua chalybeata.

\section{Haste 49}

Não há exemplos de substituição compensatória nesta haste.

\section{Haste 50}

Não há exemplos de substituição compensatória nesta haste.

\section{Domínio VI (Hastes 51-54) \\ Haste 51}

51-1: Evidência de substituição compensatória em Pygoscelis adeliae, Podiceps cristatus, Podiceps auritus, Aechmophorus occidentalis, Cathartes aura, Gymnogyps californianus, Vultur gryphus, Strigops habroptilus.

51-2: Evidência de substituição compensatória em Cathartes aura, Upupa epops, Galbula pastazae, Pteroglossus azara, Dryocopus pileatus.

51-3: Evidência de substituição compensatória em Nipponia nippon, Falco peregrinus, Falco sparverius, Strigops habroptilus, Melopsittacus undulatus, Coracias caudata, Galbula pastazae

51-4: Posição presente no modelo de mamíferos, mas não incluída no modelo de aves.

51-5: Evidência de substituição compensatória em Tinamus major, Eudromia elegans, Podiceps cristatus, Podiceps auritus, Aechmophorus occidentalis, Ciconia nigra, Ciconia ciconia, Ciconia boyciana, Phoenicopterus ruber, Alectura lathami, Ortalis guttata, Coturnix japonica, Coturnix chinensis, Gallus gallus, Gallus gallus spadiceus, Gallus sonneratii, Gallus lafayettei, Numida meleagris, Opisthocomus hoazin, Burhinus magnirostris, Arenaria interpres, Cuculus pallidus, Crotophaga ani, Urocolius macrourus, Dryocopus pileatus, Smithornis sharpei. 51-6: Posição presente no modelo de mamíferos, mas não incluída no modelo de aves. 51-7: Evidência de substituição compensatória em Eudromia elegans, Scopus umbretta, Gymnogyps californianus, Ortalis guttata, Cursorius temminckii, Catharacta skua, Larus dominicanus, Larus glaucoides, Rissa tridactyla, Sterna bengalensis, Smithornis sharpei, Cnemotriccus fuscatus, Tyrannus tyrannus.

\section{Haste 52}

52-1: Evidência de substituição compensatória em Pterocnemia pennata, Casuarius casuarius, Dromaius novaehollandie, Apteryx haastii, Pygoscelis adeliae, Gavia stellata, Gavia pacifica, Gavia immer, Podiceps cristatus, Aechmophorus occidentalis, Diomedea melanophris, Puffinus gravis, Pelecanus occidentalis, Aythya americana, Cathartes aura, Gymnogyps californianus, Vultur gryphus, Neophron percnopterus, Buteo buteo, Spizaetus alboniger, Spizaetus nipalensis, Ortalis guttata, Coturnix japonica, Coturnix chinensis, Turnix sylvatica, Grus canadensis, Jacana jacana, Nycticryphes semicollaris, Haematopus ater, Himantopus mexicanus, Cursorius temminckii, Pedionomus torquatus, Rissa tridactyla, Sterna bengalensis, Rynchops niger, Strigops habroptilus, Urocolius macrourus, Trogon collaris, Upupa epops, Galbula pastazae, Pteroglossus azara, Picoides pubescens, Smithornis sharpei, Cnemotriccus fuscatus.

52-2: Evidência de substituição compensatória em Tinamus major, Eudromia elegans, Gavia stellata, Gavia pacifica, Gavia immer, Diomedea melanophris, Puffinus gravis, Sula nebouxii, Phalacrocorax brasilianus, Cygnus columbianus, Anser albifrons, Branta canadensis, Cathartes aura, Gymnogyps californianus, Vultur gryphus, Pandion haliaetus, Falco peregrinus, Falco sparverius, Ortalis guttata, Coturnix japonica, Coturnix chinensis, Gallus gallus, Gallus gallus spadiceus, Gallus sonneratii, Gallus lafayettei, Numida meleagris, Grus canadensis, Jacana jacana, Nycticryphes semicollaris, Haematopus ater, Himantopus mexicanus, Cursorius temminckii, Charadrius semipalmatus, Charadrius vociferus, Pluvianellus socialis, Arenaria interpres, Pedionomus torquatus, Attagis gayi, Chionis minor, Larus dominicanus, Larus glaucoides, Rissa tridactyla, Sterna bengalensis, Rynchops niger, Synthliboramphus antiquus, 


\section{Continuação do Anexo 0.}

Fratercula arctica, Pterocles namaqua, Melopsittacus undulatus, Urocolius macrourus, Coracias caudata, Upupa epops, Tockus nasutus, Galbula pastazae.

52-4: Evidência de substituição compensatória em Smithornis sharpei.

52-5: Evidência de substituição compensatória em Coturnix japonica, Coturnix chinensis, Gallus gallus, Gallus gallus spadiceus, Gallus sonneratii, Gallus lafayettei, Numida meleagris, Catharacta skua.

52-6: Evidência de substituição compensatória em Upupa epops.

52-7: Posição presente no modelo de mamíferos, mas não incluída no modelo de aves.

52-8: Evidência de substituição compensatória em Tinamus major, Eudromia elegans, Himantopus mexicanus.

\section{Haste 53}

53-1: Evidência de substituição compensatória em Struthio camelus, Rhea americana, Pterocnemia pennata, Casuarius casuarius, Dromaius novaehollandie, Apteryx haastii, Dinornis giganteus, Emeus crassus, Anomalopteryx didiformis, Tinamus major, Eudromia elegans, Podiceps cristatus, Podiceps auritus, Diomedea melanophris, Anseranas semipalmata, Cygnus columbianus, Aythya americana, Buteo buteo, Spizaetus alboniger, Spizaetus nipalensis, Opisthocomus hoazin, Jacana jacana, Urocolius macrourus.

53-2: Evidência de substituição compensatória em Gavia stellata, Gavia pacifica, Gavia immer, Podiceps cristatus, Podiceps auritus, Aechmophorus occidentalis, Anser albifrons, Branta canadensis, Micrastur gilvicollis, Falco peregrinus, Falco sparverius, Coturnix japonica, Coturnix chinensis, Gallus gallus, Gallus gallus spadiceus, Gallus sonneratii, Gallus lafayettei, Numida meleagris, Pterocles namaqua, Ninox novaeseelandiae, Tockus nasutus, Pteroglossus azara, Smithornis sharpei, Cnemotriccus fuscatus.

53-3: Evidência de substituição compensatória em Cygnus columbianus, Columba livia, Strigops habroptilus, Melopsittacus undulatus, Urocolius macrourus, Dryocopus pileatus.

53-4: Posição presente no modelo de mamíferos, mas não incluída no modelo de aves. 53-6: Posição presente no modelo de mamíferos, mas não incluída no modelo de aves.

\section{Haste 54}

54-1: Posição presente no modelo de mamíferos, mas não incluída no modelo de aves.

54-2: Evidência de substituição compensatória em Struthio camelus, Rhea americana, Pterocnemia pennata, Casuarius casuarius, Dromaius novaehollandie, Apteryx haastii, Pterodroma brevirostris, Phaethon aethereus, Phaethon rubricauda, Pelecanus occidentalis, Ardea novaehollandiae, Nycticorax nycticorax, Ciconia nigra, Ciconia ciconia, Ciconia boyciana, Pandion haliaetus, Neophron percnopterus, Buteo buteo, Spizaetus alboniger, Spizaetus nipalensis, Falco peregrinus, Falco sparverius, Opisthocomus hoazin, Turnix sylvatica, Catharacta skua, Columba livia, Melopsittacus undulatus, Coccyzus americanus, Bubo virginianus, Ninox novaeseelandiae, Chordeiles acutipennis, Apus apus, Apus affinus, Urocolius macrourus, Tockus nasutus, Smithornis sharpei.

54-3: Evidência de substituição compensatória em Turnix sylvatica, Strigops habroptilus.

54-4: Evidência de substituição compensatória em Smithornis sharpei. 


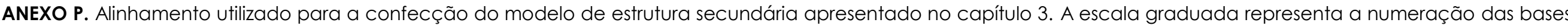

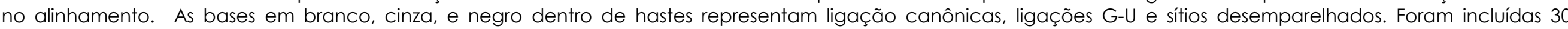

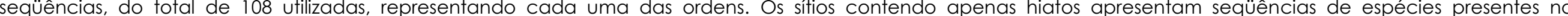

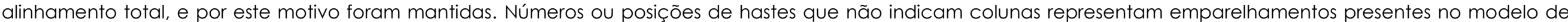
mamíferos, mas não incluídos aqui.

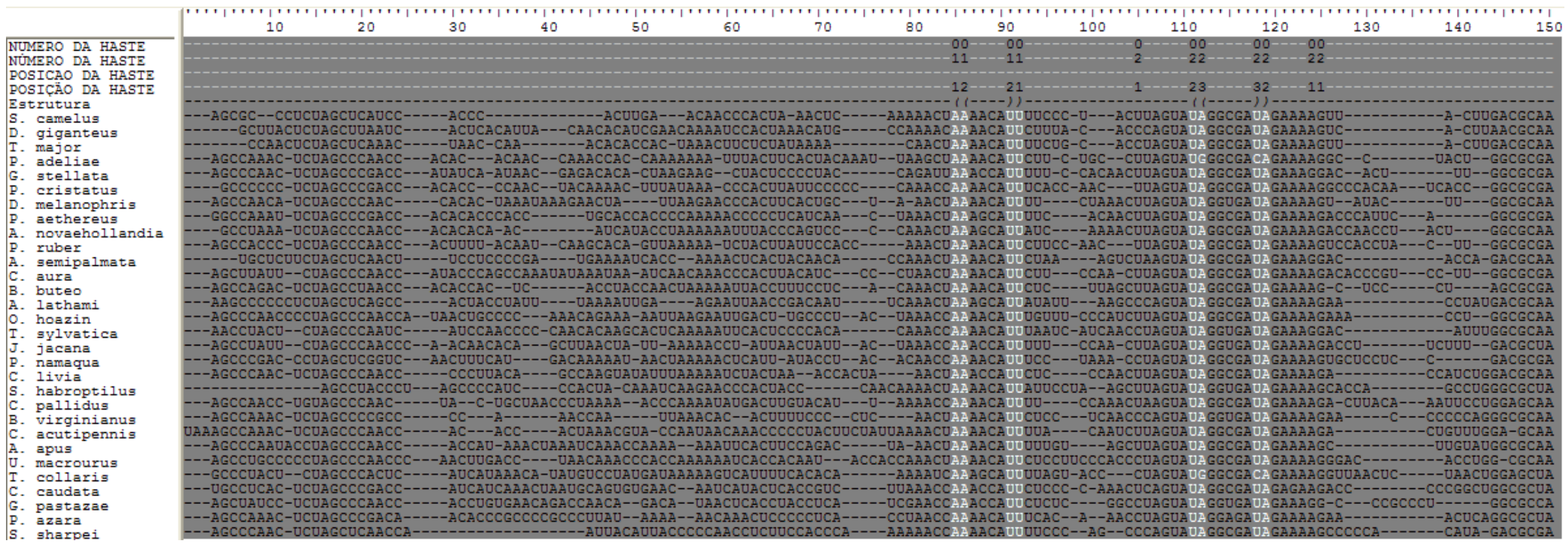


Continuação Anexo P.

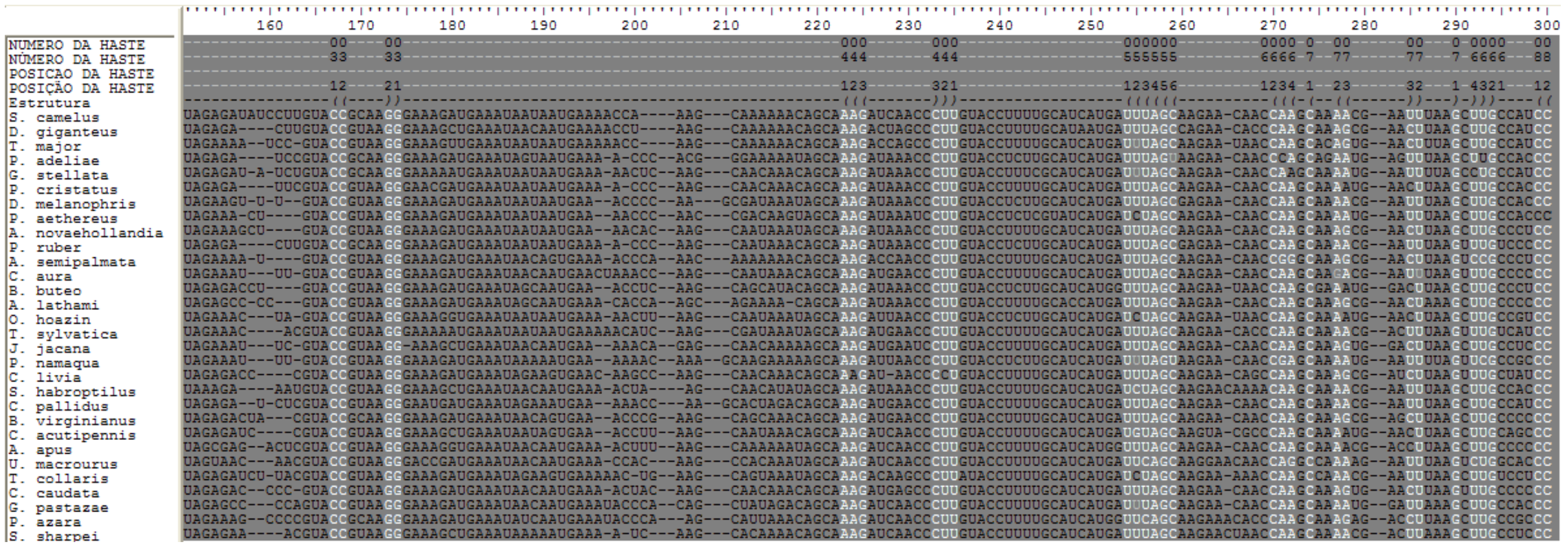


Continuação Anexo P.

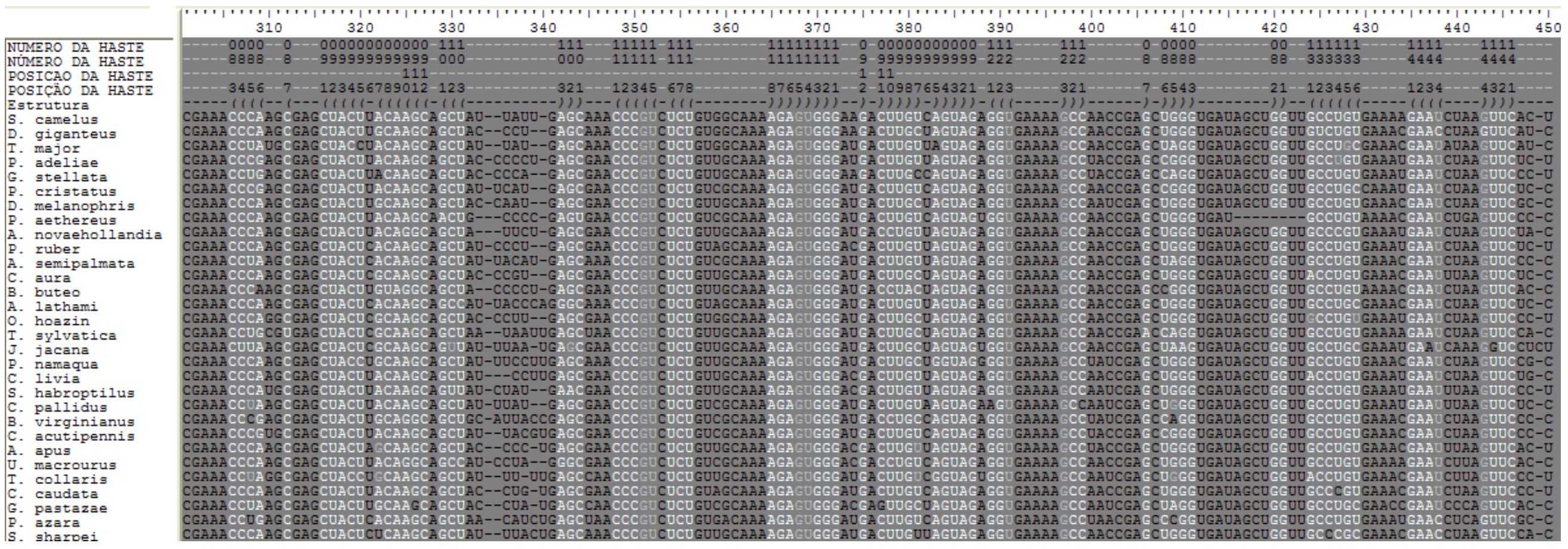




\section{Continuação Anexo P.}

NUMERO DA HASTE
NUMERO DA HASTE
POSICAO DA HASTE
POSICAO DA HASTE
Estrutura
S. camelus
D. giganteus
T. major
P. adeliae
G. stellata
P. cristatus
D. melanophris
P. aethereus
A. novaehollandia
P. ruber
A. semipalmata
C. aura
B. buteo
A. lathami
O. hoazin
T. sylvatica
J. jacana
P. namaqua
C. livia
S. habroptilus
C. pallidus
B. virginianus
C. acutipennis
A. apus
U. macrourus
T. collaris
C. caudata
G. pastaza
P. azara
S. sharpei

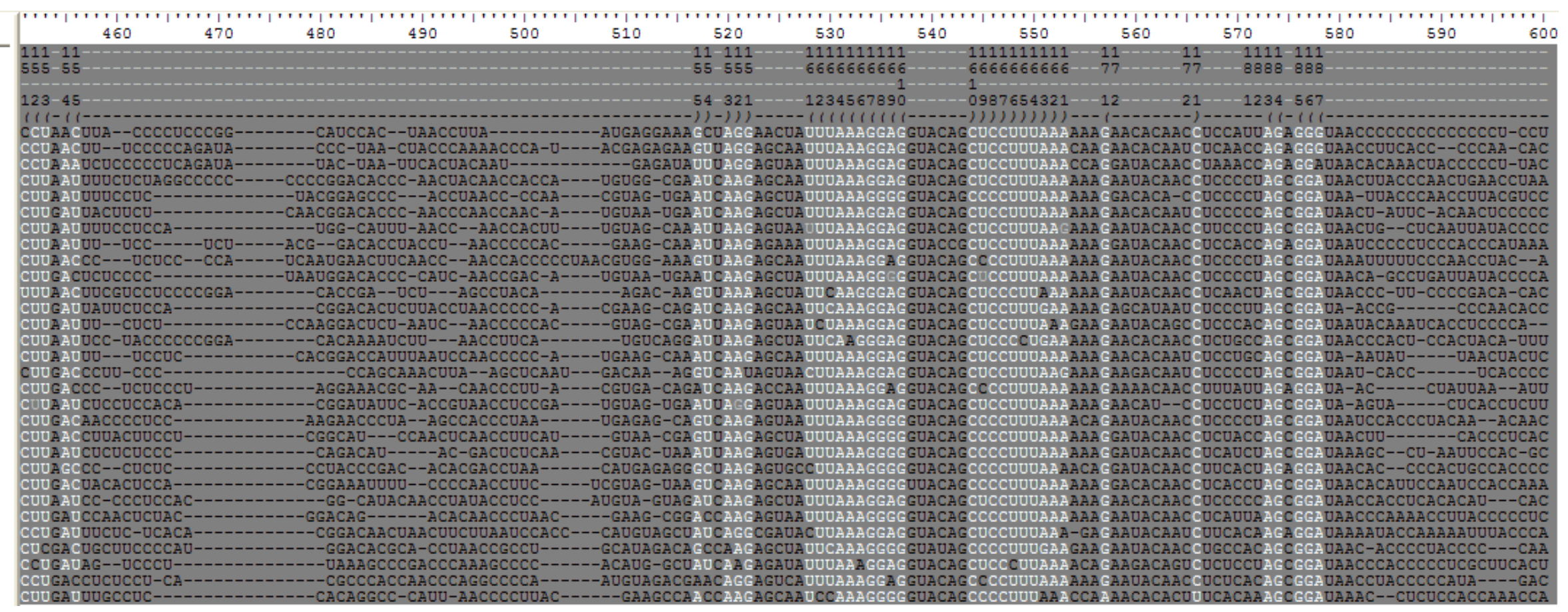




\section{Continuação Anexo P.}

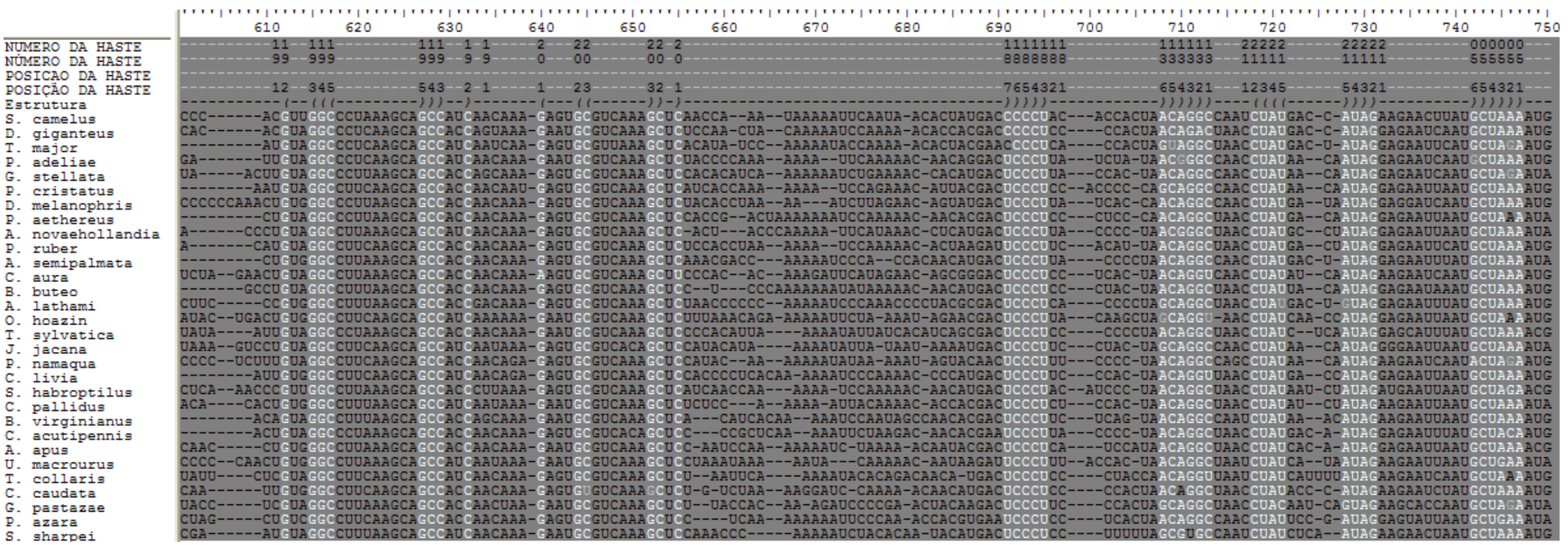


Continuação Anexo P.

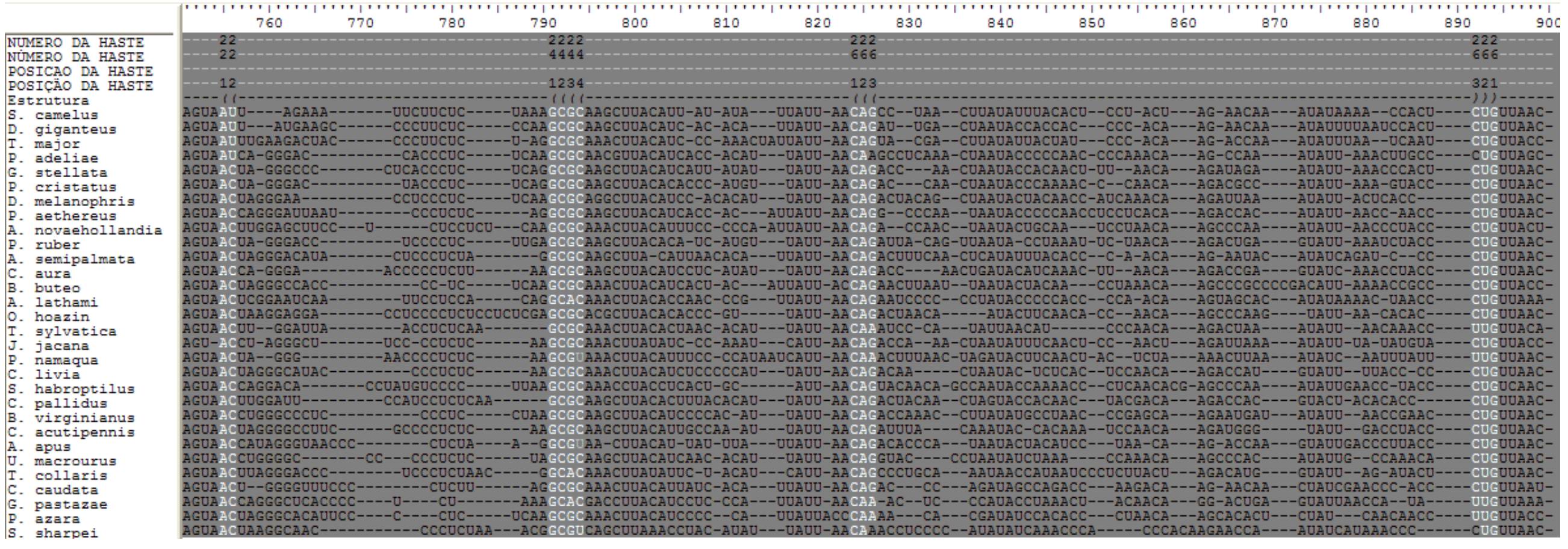




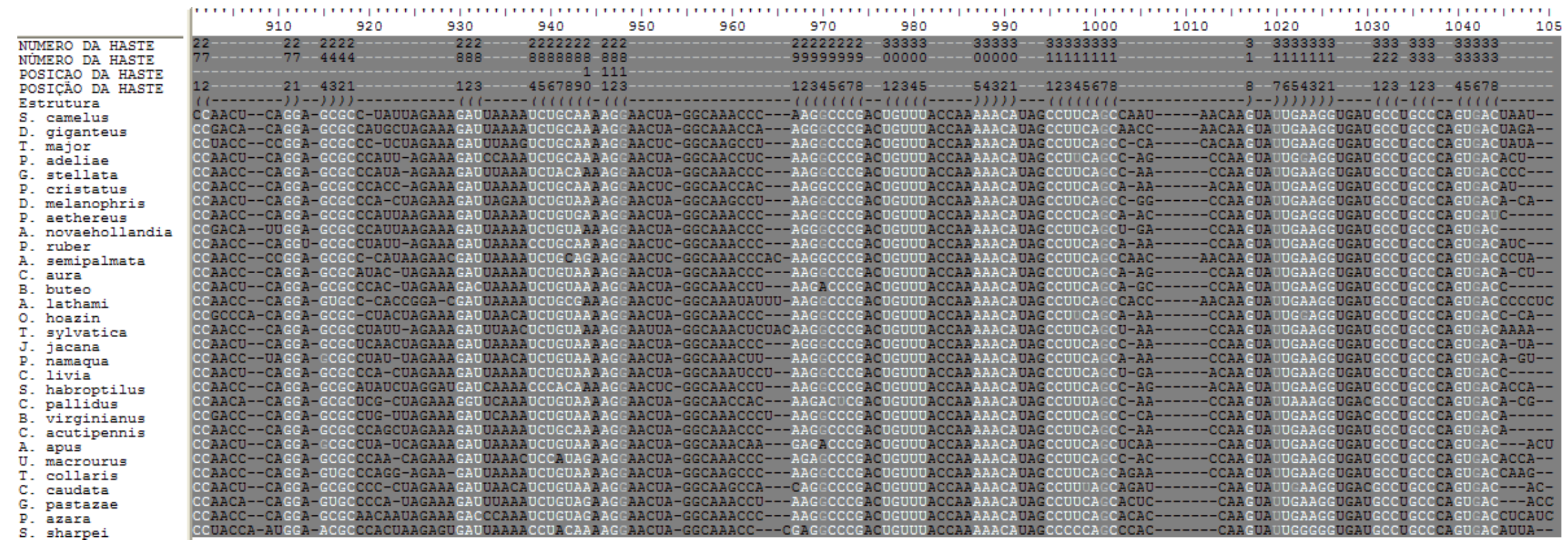


Continuação Anexo P.

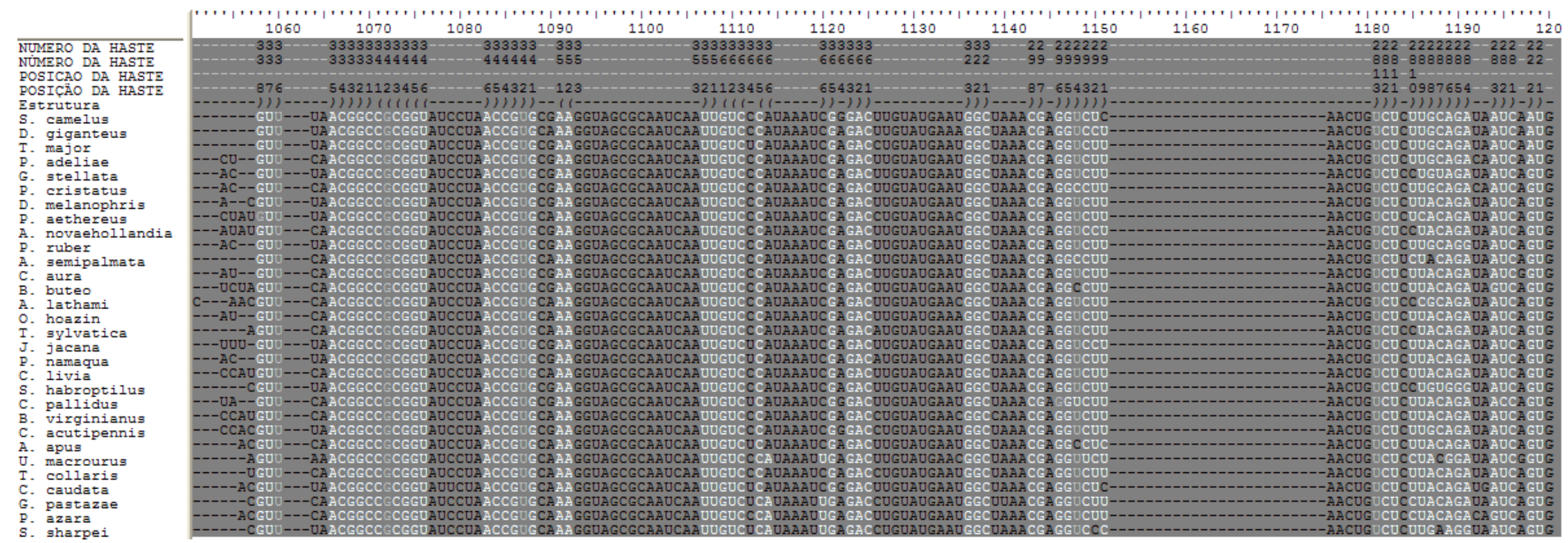




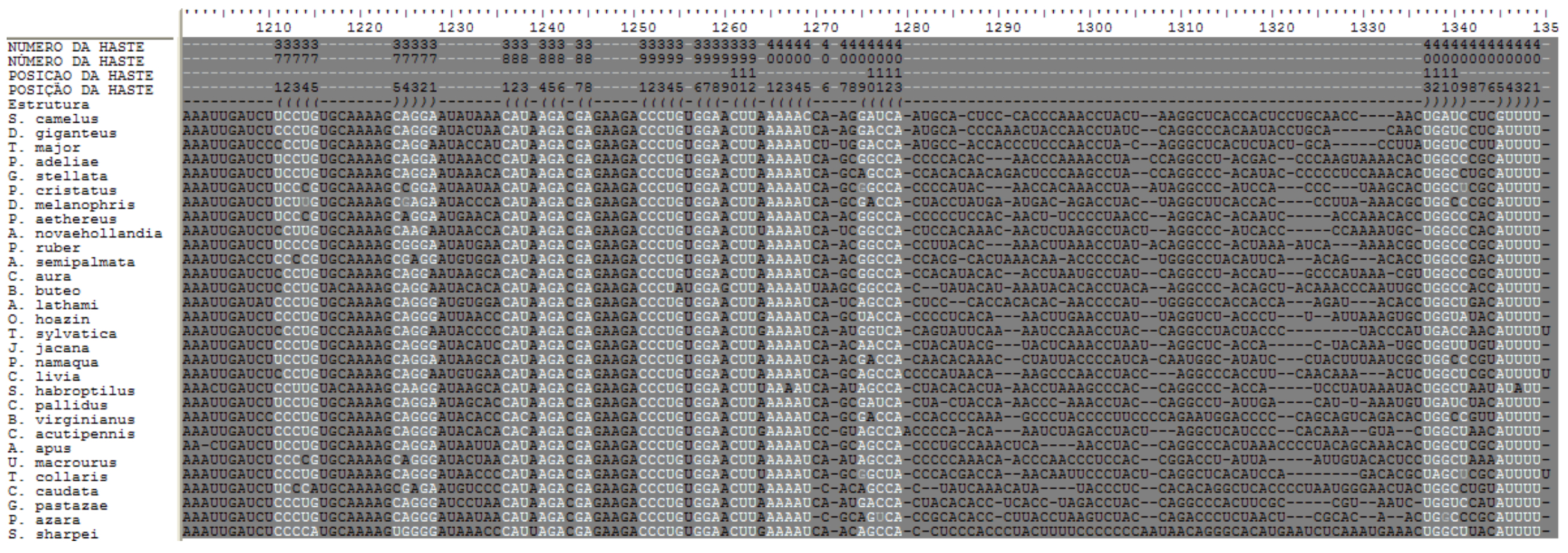




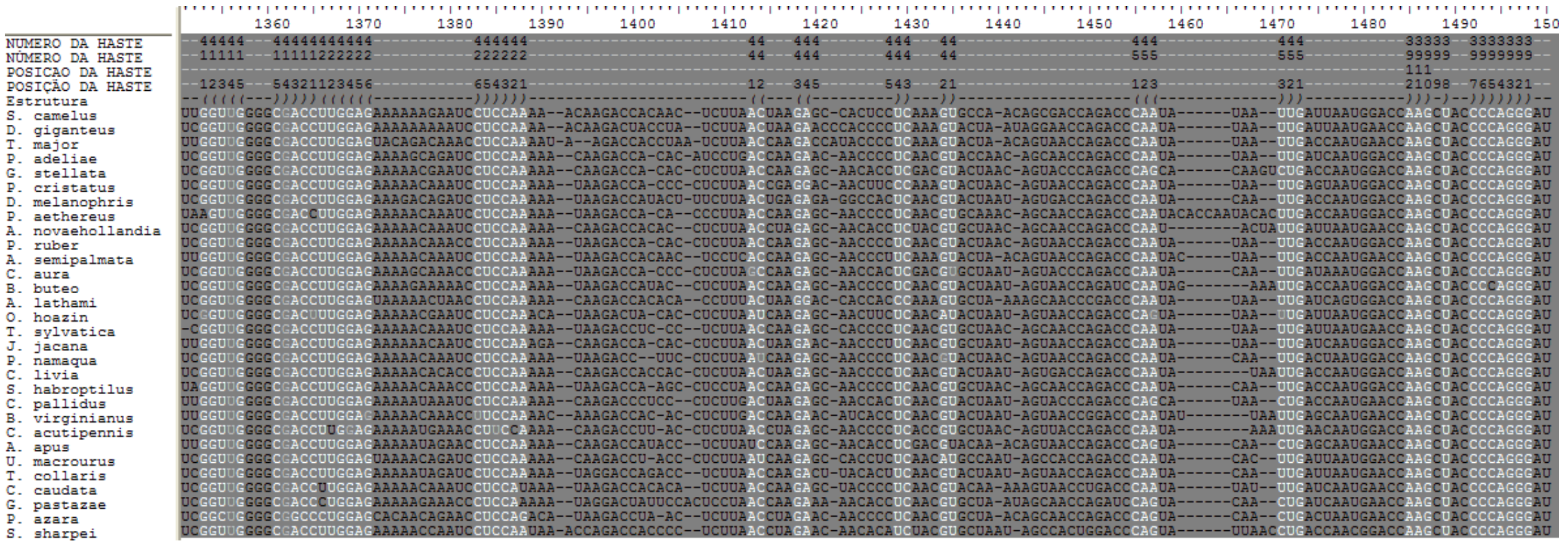




\section{Continuação Anexo P.}

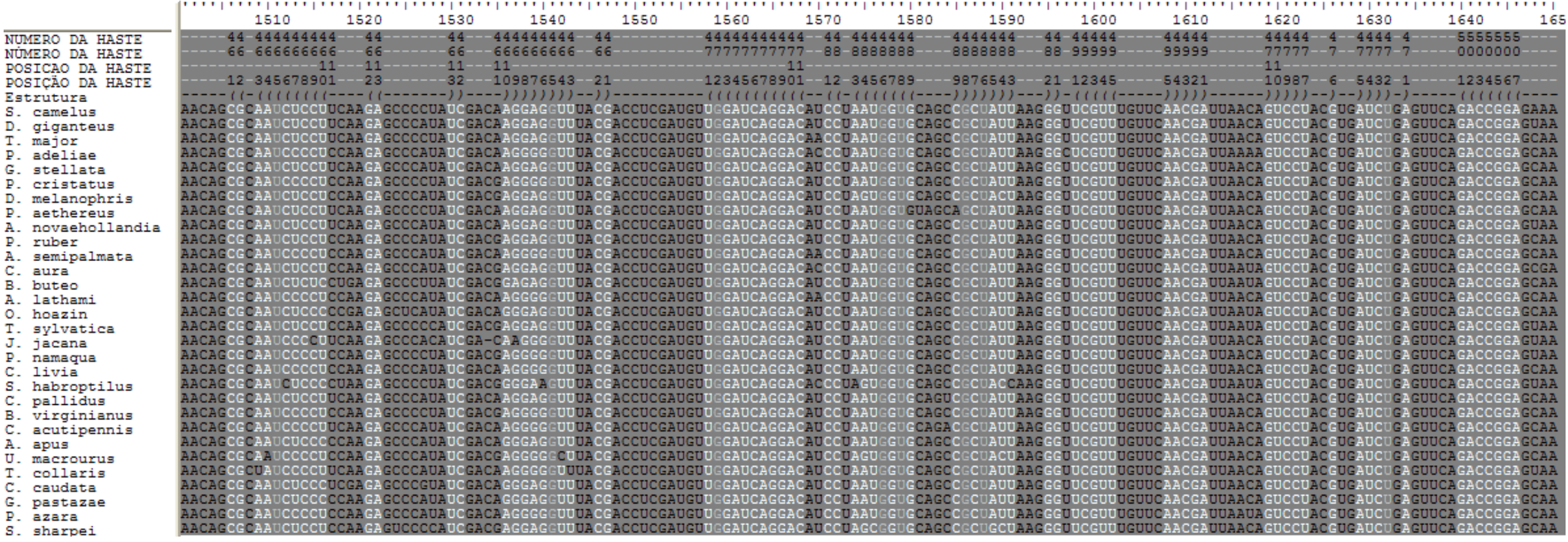




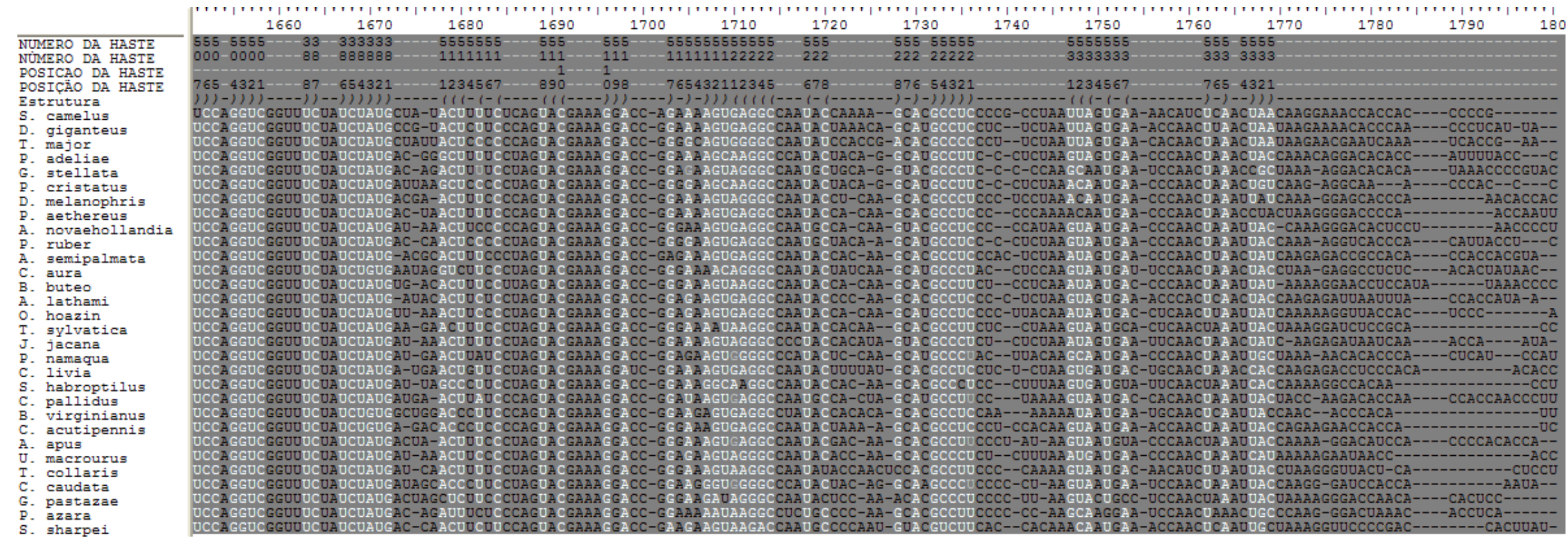


Continuação Anexo P.

\begin{tabular}{|c|c|}
\hline & 1810 \\
\hline MERO DA HAS & \\
\hline NUMERO DA HASTE & 4444 \\
\hline $\begin{array}{l}\text { POSICAO DA HASTE } \\
\text { POSICÄO DA HASTE }\end{array}$ & $-1234=$ \\
\hline Estrutura & \\
\hline S. camelus & -- A \\
\hline D. giganteus & $-C A$ \\
\hline T. major & $A A-A G$ \\
\hline adeliae & $A--A G E$ \\
\hline G. stellata & $A A--A G G$ \\
\hline cristatus & AA- \\
\hline D. melanophris & GCU-- \\
\hline $\begin{array}{l}\text { P. aethereus } \\
\text { A. novaehollandia }\end{array}$ & $J A--A E C$ \\
\hline P. ruber & AA--AGGACCGCU- \\
\hline A. semipalmata & $\begin{array}{l}A A--A G G A D U A \\
A A--A G C A C D A-\end{array}$ \\
\hline & $\begin{array}{l}A A--A E \\
A--A E\end{array}$ \\
\hline $\begin{array}{l}\text { B. buteo } \\
\text { A. lathami }\end{array}$ & CAAGAAA--AGGACCUAA- \\
\hline 0 . hoazin & GAAA- -AGEGCCCAG- \\
\hline I. sylvatica & GAUA--AGAGGCCCGCU- \\
\hline J. jacana & 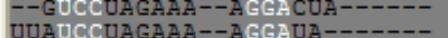 \\
\hline $\begin{array}{l}\text { P. namaqu } \\
\text { C. livia }\end{array}$ & AAA--AEGECCGCU-- \\
\hline S. habroptilus & $A A A-D E$ \\
\hline C. pallidus & AAAA-DE \\
\hline B. virginianus & UAGACA--AGEGUAGCU \\
\hline C. acutipennis & CCGCCCUAGAAA--ACGECCGCU---- \\
\hline A. apus & $\begin{array}{l}\text { CUGCCCUAGAAA--AGEGCC-------- } \\
\text { UUGCCCUAGACA--AGGECAUUCGCU- }\end{array}$ \\
\hline $\begin{array}{l}\text { U. macroux } \\
\text { T. collar }\end{array}$ & ACAUCCUAGAAA--AGGACCCAGCU-- \\
\hline $\begin{array}{l}\text { 1. collaria } \\
\text { C. caudata }\end{array}$ & CAGCU \\
\hline G. pastazae & $\mathrm{ACCA}-$ \\
\hline P. azara & $\begin{array}{l}- \text { - ACCCUAAAAA--AGGAAA--- } \\
--G C C U U A G A A A--A A G C C C C--\end{array}$ \\
\hline S. sharpei & \\
\hline
\end{tabular}


Anexo Q. AMARAL, F. S. R., MILLER, M. J., SILVEIRA, L. F., BERMINGHAM, E., WAJNTAL, A. Polyphyly of the hawk genera Leucopternis and Buteogallus (Aves, Accipitridae): multiple habitat shifts during the Neotropical buteonine diversification. BMC Evolutionary Biology, v. 6, p. 10. 2006. 


\title{
Polyphyly of the hawk genera Leucopternis and Buteogallus (Aves, Accipitridae): multiple habitat shifts during the Neotropical buteonine diversification

\author{
Eldredge Bermingham ${ }^{2}$ and Anita Wajntal ${ }^{1}$
} \\ Fabio S Raposo do Amaral*1, Matthew J Miller², Luís Fábio Silveira²,
}

Address: ${ }^{1}$ Departamento de Genética e Biologia Evolutiva, Universidade de São Paulo, São Paulo. Rua do Matão, 277, Cidade Universitária, São Paulo, SP, CEP 05508-900, Brasil, 2'Smithsonian Tropical Research Institute, Apartado 2072, Balboa, Panamá and ${ }^{3}$ Departamento de Zoologia, Universidade de São Paulo, São Paulo. Rua do Matão, Travessa 14, n 321, Cidade Universitária, São Paulo, SP, CEP 05508-900, Brasil

Email: Fabio S Raposo do Amaral* - fabioraposo@hotmail.com; Matthew J Miller - millerma@si.edu; Luís Fábio Silveira - lfsilvei@usp.br; Eldredge Bermingham - bermingb@si.edu; Anita Wajntal - aniwa@usp.br

* Corresponding author

Published: 07 February 2006

BMC Evolutionary Biology2006, 6:10 doi:10.1186/147/-2148-6-10

This article is available from: http://www.biomedcentral.com/I47I-2148/6/10

(c) 2006do Amaral et al; licensee BioMed Central Ltd.

This is an Open Access article distributed under the terms of the Creative Commons Attribution License (http://creativecommons.org/licenses/by/2.0), which permits unrestricted use, distribution, and reproduction in any medium, provided the original work is properly cited.

\begin{abstract}
Background: The family Accipitridae (hawks, eagles and Old World vultures) represents a large radiation of predatory birds with an almost global distribution, although most species of this family occur in the Neotropics. Despite great morphological and ecological diversity, the evolutionary relationships in the family have been poorly explored at all taxonomic levels. Using sequences from four mitochondrial genes (I2S, ATP8, ATP6, and ND6), we reconstructed the phylogeny of the Neotropical forest hawk genus Leucopternis and most of the allied genera of Neotropical buteonines. Our goals were to infer the evolutionary relationships among species of Leucopternis, estimate their relationships to other buteonine genera, evaluate the phylogenetic significance of the white and black plumage patterns common to most Leucopternis species, and assess general patterns of diversification of the group with respect to species' affiliations with Neotropical regions and habitats.
\end{abstract}

Results: Our molecular phylogeny for the genus Leucopternis and its allies disagrees sharply with traditional taxonomic arrangements for the group, and we present new hypotheses of relationships for a number of species. The mtDNA phylogenetic trees derived from analysis of the combined data posit a polyphyletic relationship among species of Leucopternis, Buteogallus and Buteo. Three highly supported clades containing Leucopternis species were recovered in our phylogenetic reconstructions. The first clade consisted of the sister pairs L. lacernulatus and Buteogallus meridionalis, and Buteogallus urubitinga and Harpyhaliaetus coronatus, in addition to $L$. schistaceus and $L$. plumbeus. The second clade included the sister pair Leucopternis albicollis and $L$. occidentalis as well as $L$. polionotus. The third lineage comprised the sister pair $L$. melanops and $L$. kuhli, in addition to $L$. semiplumbeus and Buteo buteo. According to our results, the white and black plumage patterns have evolved at least twice in the group. Furthermore, species found to the east and west of the Andes (cis-Andean and trans-Andean, respectively) are not reciprocally monophyletic, nor are forest and non-forest species.

Conclusion: The polyphyly of Leucopternis, Buteogallus and Buteo establishes a lack of concordance of current Accipitridae taxonomy with the mtDNA phylogeny for the group, and points to the need for further phylogenetic analysis at all taxonomic levels in the family as also suggested by other recent analyses. Habitat shifts, as well as cis- and trans-Andean disjunctions, took place more than once during buteonine diversification in the Neotropical region. Overemphasis of the black and white plumage patterns has led to questionable conclusions regarding the relationships of Leucopternis species, and suggests more generally that plumage characters should be used with considerable caution in the taxonomic evaluation of the Accipitridae. 


\section{Background}

The family Accipitridae comprises approximately 237 species of predatory birds distributed worldwide except Antarctica [1], with diversity concentrated in the Neotropics $[1,2]$. Despite numerous taxonomic revisions (e.g., $[3,4])$, the evolutionary history of the family has not been sufficiently explored using methods of phylogenetic inference, and current classifications are mainly based on plumage and ecological resemblance between taxa [5]. Current taxonomy is still highly provisional at all taxonomic levels $[1,6]$, and does not appear to reflect phylogenetic relationships in several cases $[7,8]$, thus retarding biogeographic analysis, morphological trait mapping and the general understanding of the evolutionary history of the Accipitridae.

The Accipitridae morphological diversity has been traditionally represented in sub-groups of similar or supposedly closely related species, such as "kites", "harriers", "booted eagles" and "buteonines" [1]. The buteonine hawks are represented by the large cosmopolitan genus Buteo and several related genera, called "sub-buteonines" by Amadon [4], which includes the predominantly Neotropical genera Buteogallus, Parabuteo, Asturina, Leucopternis, Busarellus, Geranoaetus, Geranospiza and Harpyhaliaetus. Two old world genera, Kaupifalco and Butastur, were formerly included as part of the "sub-buteonines" group, but were subsequently removed from this division [9]. Some authors consider the buteonine as a sub-family (Buteonineae, e.g. Friedman [10], Grossman and Hamlet [11]), but formal sub-familial division of Accipitridae has been a contentious issue due to a lack of knowledge of the evolutionary history of the family (see $[9,12])$.

Evolutionary biologists have long sought to understand the processes responsible for the generation of the high species richness found in the Neotropics, and several models of biotic diversification have been invoked to explain such patterns, for example forest refuges resulting from climatic fluctuations [13-15], rivers as barriers to gene flow [16], river dynamics [17], sea level oscillations [18-20], geotectonic vicariance [21] and ecological factors [22] (see Moritz et al. [23] for a revision). However, these models have only rarely been tested with organisms capable of long-distance dispersal (e.g., $[24,25])$, such as hawks and eagles capable of soaring and gliding flight. Numerous flocks of migrant hawk species as Buteo platypterus and Buteo swainsoni, for example, cross the Andes as part of their yearly migrations [26], and call into question the degree to which the geographical barriers to gene flow identified in many models of Neotropical diversification have been important in Accipitridae speciation.
The genus Leucopternis is a morphologically heterogeneous group of 10 buteonine species distributed in forested habitats from southern Mexico to Paraguay and Uruguay [1], and offers an opportunity to explore the diversification of an Accipitridae group distributed throughout the Neotropical region. Species in the genus vary from the small L. semiplumbeus ( $250 \mathrm{~g}$ ) to the large L. princeps ( $1 \mathrm{~kg}$ ) [1], and are hawks with broad wings and medium to short tails. Two species, L. schistaceus and L. plumbeus, are entirely dark slate; however, most Leucopternis have primarily white plumage and vary in the amount of black, grey or slate black on the back, wings and/or head. Those which we here refer to as "black-and-white" Leucopternis species are L. albicollis, L. polionotus, L. occidentalis, L. lacernulatus, L. melanops, L. kuhli, L. semiplumbeus, and L. princeps $[1,6]$. While Leucopternis are found exclusively in forest habitats, other Neotropical buteonine species occur in a variety of habitats, such as mangroves (Buteogallus aequinoctialis), savannahs (Harpyhaliaetus coronatus, Buteogallus meridionalis) and wetlands (Busarellus nigricollis) $[1,6]$, which makes this group suitable to analysis of the evolutionary relationships of forest and non-forest species.

The buteonine phylogeny has been partially explored recently using morphological and molecular data $[7,27,28]$, but Neotropical species have not been well represented. Incomplete taxon sampling notwithstanding, these analyses have called into question the monophyly of Leucopternis, Buteo and Buteogallus $[7,28]$. The present work constitutes an effort to clarify the relationships among all Leucopternis species, and their position relative to other Neotropical buteonine genera. We address the following questions: (1) Is Leucopternis as currently recognized monophyletic? (2) What are the relationships among species of Leucopternis to other genera of buteonine hawks? (3) Is the black and white plumage pattern a synapomorphic trait uniting the majority of species in the genus Leucopternis? (4) Are phylogenetic relationships among Neotropical buteonines predicted by biogeography or habitat?

\section{Results \\ Datasets, molecular variation}

Our final alignment of the total dataset (12S, ATP8 and 6 and ND6) without gaps totalled 2179 base pairs, with 651 variable and 505 parsimony informative sites. Uncorrected distances ranged from 0 to $7.1 \%$ for $12 \mathrm{~S}$ (without gaps), 0 to $21.4 \%$ for ATP8, 0 to $11.9 \%$ for ATP6, and 0 to $13.9 \%$ for ND6. Deviations from linearity were found in third position plots of ATP8, ATP6 and ND6. We did not detect significant departures from homogeneity of base frequencies across taxa in any dataset $(P>0.05$, data not shown). We are confident of mitochondrial origin of our sequences because: (1) most of our samples were repre- 


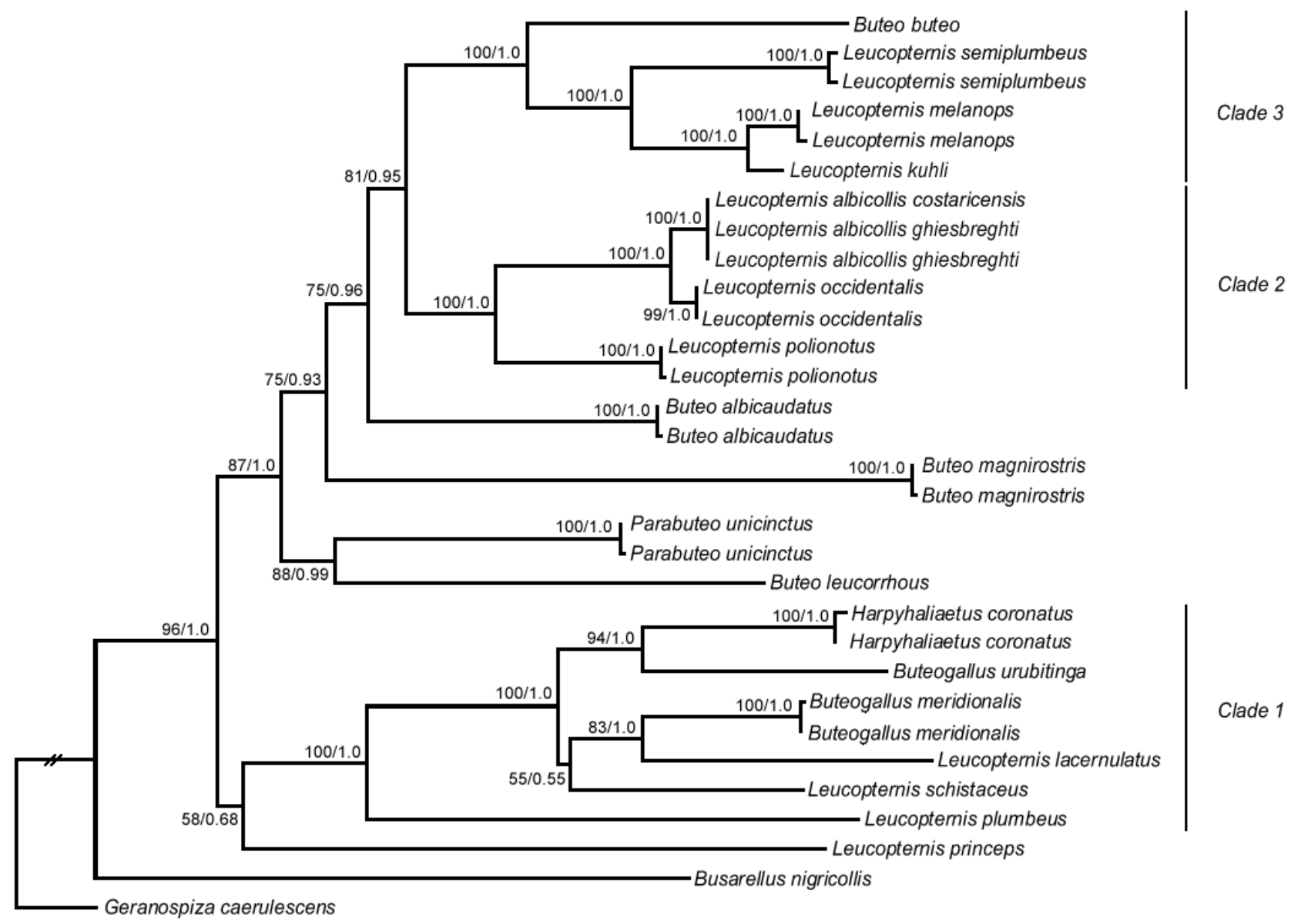

0.05 substitutions/site

Figure I

Maximum likelihood topology of Leucopternis species and other Neotropical buteonines obtained from the combined data. Numbers to the left of the node represent maximum likelihood bootstrap proportions (before slash) and Bayesian posterior probabilities (after slash). The branch leading to the outgroup was shortened for illustrative purposes.

sented by mitochondrial-rich tissues (feathers, muscle or liver); (2) most samples (comprising 12 of 20 species) had all regions sequenced using independent fragments amplified with different primer sets (with sequence overlap ranging from 67 to more than $400 \mathrm{bp}$, in highly variable regions), and sequences were identical; (3) sequences were easily aligned to published sequences of other Accipitridae species; (4) electropherograms were carefully checked for double peaks; (5) coding regions did not show unexpected stop codons; and 6) gene specific phylogenetic analyses revealed similar relationships to those inferred from the combined data, indicating that a mitochondrial translocation to the nucleus would have to have been more than eight kilobases in length.
A single nucleotide site in the $12 \mathrm{~S}$ sequence of the muscle sample LGEMA F39 (L. lacernulatus) presented a strong " $C$ " peak with a lower "A" peak at the position 593, and this same pattern persisted in sequences obtained from amplifications using three different primer combinations, with sizes ranging from approximately 800 to $2700 \mathrm{bp}$. The sequence can be easily aligned and has a base composition similar to other published sequences for the Accipitridae. We could not find any evidence of pseudogene amplification, and since it has been suggested that PCR amplifications larger than 1.5 kilobases are likely to represent true mitochondrial amplifications [29], this site was coded as "M" (IUPAC code representing $C$ and $A$ ) in all analyses, and it may represent an example of mitochondrial heteroplasmy. 

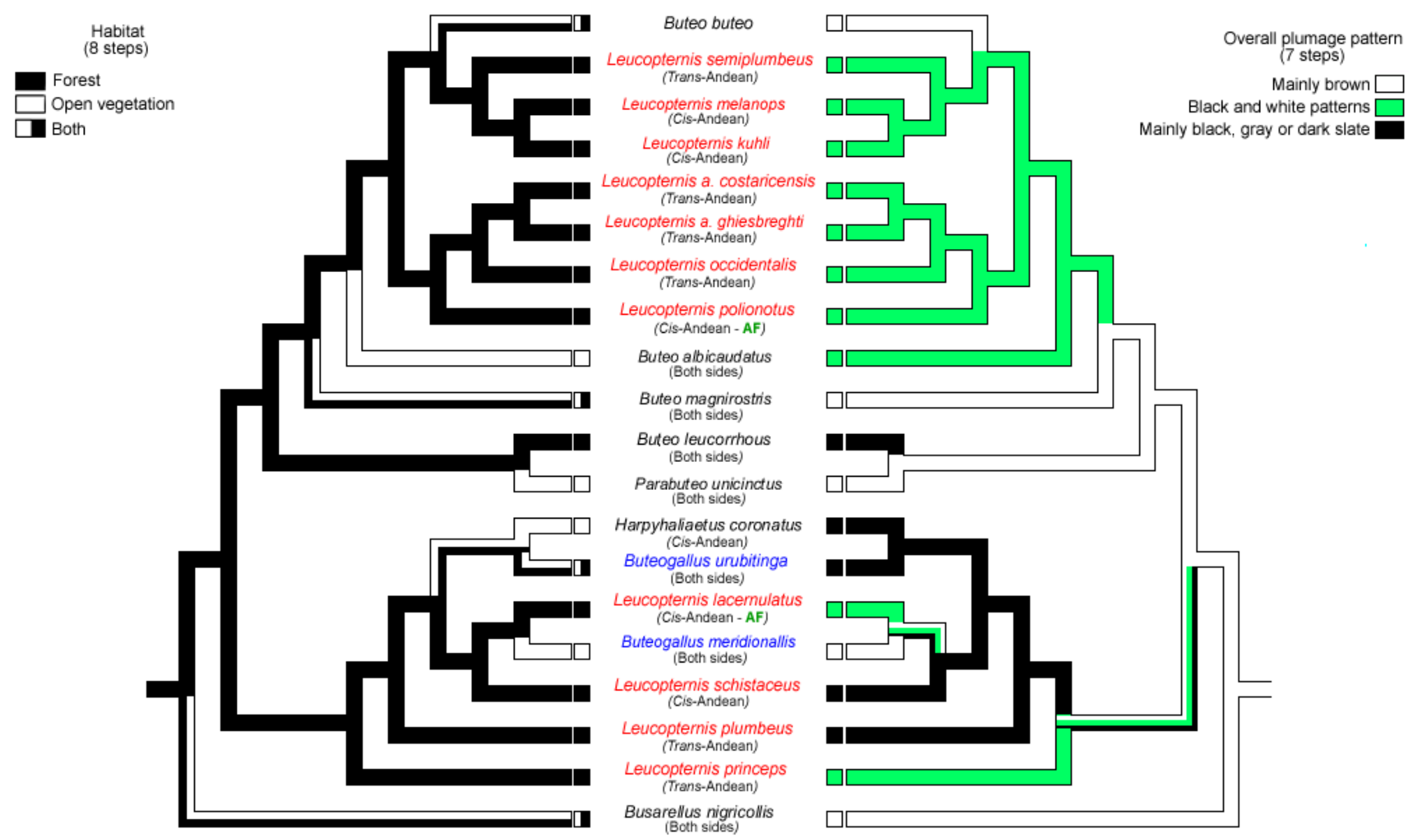

Figure 2

Ancestral state reconstruction of habitat preferences and plumage characters of Leucopternis species and Neotropical buteonines. Reconstructions determined by unordered parsimony using the ML topology obtained from the combined dataset. Species of Leucopternis and Buteogallus are indicated in red and blue. AF represents Atlantic Forest.

\section{Phylogenetic analysis, single and combined datasets}

None of the phylogenetic analyses supported the monophyly of the hawk genera Leucopternis, Buteogallus or Buteo. Phylogenies inferred from the subsets of mtDNA genes and combined data were largely congruent under all optimization criteria, and topologies differed mainly in resolution and nodal support. Although phylogenetic analysis of single gene subsets resulted in poorly resolved trees (data not shown), the nodes identified with high bootstrap support $(>75)$ or posterior probabilities $(>0.95)$ were entirely congruent with those identified in the combined analyses.

The maximum likelihood (ML) inference of the total dataset resulted in one completely resolved tree with likelihood -ln 9813.2993 (figure 1), which was identical to the majority rule consensus topology of the Bayesian analysis (BA). Most nodes were highly supported by both bootstrap proportions and posterior probabilities. Maximum parsimony (MP) analyses of the total dataset resulted in two equally parsimonious trees (1531 steps, CI $=0.4899$, $\mathrm{RI}=0.6938$ ) (trees not shown), which were also highly congruent with the ML and BA inferences. The main dif- ferences between the MP trees and the other combined analyses were the position of $L$. princeps basal to Clades 2 and 3 plus the remaining Buteo species and Parabuteo unicinctus (bootstrap support 68, data not shown), and the position of L. schistaceus basal to a poorly supported clade containing the sister pairs Buteogallus meridionalis and L. lacernulatus, and H. coronatus and Buteogallus urubitinga (bootstrap support $<50$, data not shown).

Three major mtDNA clades containing Leucopternis species (figure 1) were recovered in all combined analysis, with high levels of statistical support in most cases. Clade 1 included Buteogallus meridionalis, L. lacernulatus, Buteogallus urubitinga, H. coronatus, L. schistaceus and $L$. plumbeus; Leucopternis princeps was basal to this Clade 1 in the ML and BA analyses, but with low support. The ML and BA analyses strongly supported a sister relationship between L. lacernulatus and Buteogallus meridionalis, and between $H$. coronatus and $B$. urubitinga; the latter sister pair was also highly supported by parsimony bootstrap (bootstrap support 98, data not shown). There was weaker support for a sister relationship between L. schistaceus and Buteogallus meridionalis plus L. lacernulatus, obtained in the 
$\mathrm{ML}$ and BA analyses. All phylogenetic trees inferred from the combined dataset establish an early split of $L$. plumbeus from the rest of the Clade 1 .

Clade 2 comprised the two sampled L. albicollis subspecies (which carried identical mtDNA sequences), L. occidentalis and L. polionotus. Clade 3 was sister to Clade 2 and included L. semiplumbeus, L. melanops and L. kuhli sister to Buteo buteo. Buteo albicaudatus, Buteo magnirostris, Parabuteo unicinctus and Buteo leucorrhous were outside the sister relationship of Clade 2 and Clade 3 in all analyses. There was strong support in the ML, MP and BA trees obtained from the combined dataset for a sister relationship between Buteo leucorrhous and P. unicinctus.

Shimodaira-Hasegawa tests were conducted on topologies constrained by the monophyly of all species in the genus Leucopternis, monophyly of species with the black and white plumage pattern, monophyly of all forest species, and reciprocal monophyly of the cis- and trans-Andean species. In all tests the constraint trees had a significantly poorer fit to the data than the unconstrained ML tree $(\mathrm{P}<$ 0.001). Ancestral state reconstructions of habitat and plumage traits onto the ML tree using unordered parsimony (Figure 2) showed that the black-and-white plumage characteristic to most Leucopternis species evolved at least twice in Neotropical buteonines, and shifts between forest and open habitats occurred at least four times.

\section{Discussion \\ Phylogenetic relationships, novel groupings, and evolution of common plumage patterns}

The mtDNA-based phylogenies for Neotropical buteonines reject the monophyly of the genera Leucopternis, Buteogallus and Buteo. Our analysis provides another example of the lack of correspondence between classic taxonomic groupings within the Accipitridae and molecular phylogenies $[7,8,28]$. The genus Leucopternis is a composite of three independent lineages, and several Leucopternis species are more closely related to other buteonine taxa than to each other.

One of the novel phylogenetic arrangements presented here is the sister relationship between L. lacernulatus and Buteogallus meridionalis, rather than between L. lacernulatus and the sympatric Atlantic forest endemic L. polionotus, despite overall similarities in plumage pattern between the latter pair (see [30]). A proposed close relationship $[1,4,12,30]$ between $L$. lacernulatus and the L. melanops/L. kuhli complex was not supported in any of our analyses.

Although close association of L. lacernulatus and B. meridionalis was unanticipated, the distinctiveness of the latter from other Buteogallus species has been recognized by its placement by some authors in the monotypic genus Het- erospizias (e.g.,[10,11,30-34]). A close relationship between Buteogallus urubitinga, and Harpyhaliaetus eagles has been previously suggested $[35,36]$, and the retention of the former in Buteogallus has been justified only by the bigger size of the Harpyhaliaetus species [35]. A recent higher-level molecular analysis of hawks and eagles [28] posited the paraphyly of the genus Buteogallus, and established a closer relationship of Buteogallus urubitinga and Harpyhaliaetus species than between the two Buteogallus species sampled (B. urubitinga and B. anthracinus). Given the polyphyletic relationships of Buteogallus as presented here it is clear that a complete re-assessment of the genus is required. It is worth noting that Amadon [4], Grossman and Hamlet [11], Brown and Amadon [12] and Ridgway [37] predicted the relatively close relationship of $L$. schistaceus and L. plumbeus to Buteogallus established in the mtDNA phylogeny presented here. However, we did not recover a sister relationship between the latter pair, sometimes considered subspecies [30] or members of a superspecies complex (e.g., $[9,38,39])$.

The proximity of L. polionotus, L. albicollis and L. occidentalis is fully supported by our data, and has been strongly suggested in taxonomic revisions (e.g., $[1,3,4,6,9,12,30,38,39])$. Species limits in the L. albicollis complex have been a contentious taxonomic issue, and revision of this complex is needed. Similarly, a sister relationship between L. melanops and L. kuhli has been long suggested (e.g., $[1,4,6,30,38-40])$, as well as the close relationship of both to L. semiplumbeus [12], based on similarities of plumage and external morphology. However, their close relationship to Buteo buteo is novel (see also [28]). In our study, Buteo buteo represents a genus containing several species of North American and Old World hawks (see [7]), and the nested position of this species within the Neotropical buteonines corroborates Amadon's [4] hypothesis of Neotropical origins for the entire buteonine lineage. The polyphyly of Buteo species in our study corroborates the results of Riesing et al. [7].

Our study includes all recognized Leucopternis species and represents the largest Neotropical buteonine taxonomic sample investigated to date. The polyphyly of Leucopternis, Buteogallus and Buteo indicates that current taxonomy does not reflect the phylogenetic history of the group. Only a complete buteonine phylogeny is likely to provide sufficient guidance regarding the nomenclatural issues concerning Buteo, Leucopternis, Buteogallus and Harpyhaliaetus, as well as fine scale biogeographic inferences. The predominantly black and white plumage pattern shared by several Leucopternis species (L. polionotus, L. occidentalis, L. lacernulatus, L. melanops, L. kuhli, L. semiplumbeus, $L$. albicollis, L. princeps) has evolved at least twice (figure 2), and the widespread occurrence of this pattern may result from plumage convergence in forested habitats. Similarly, 
L. plumbeus and L. schistaceus posses a slate plumage pattern very similar to that of Rostrhamus species, and all those species are associated with riparian habitats both within (L. schistaceus, L. plumbeus, R. hamatus) and outside forests ( $R$. sociabilis). In order to test the hypothesis that the slate plumage results from selection in riparian habitats, additional analysis including Rostrhamus species is required. It has been shown that plumage characters under strong selection may evolve rapidly [41], and in some cases may represent evolutionary convergence instead of reflecting shared phylogenetic or phylogeographic history [42]. An overemphasis on the black and white plumage pattern influenced the grouping of Leucopternis species, and more generally our results indicate that plumage patterns alone may not be reliable taxonomic markers among Accipitridae species.

\section{Biogeography and habitat shifts}

We can confidently reject the reciprocal monophyly of cisand trans-Andean distributed buteonines (figure 2). At least three cis-trans (east-west) disjunctions were identified in all phylogenetic trees inferred from the combined dataset: (1) L. semiplumbeus (trans-) versus its Amazonian (cis-) sister clade, L. melanops plus L. kuhli, (2) L. polionotus (cis-) versus the two sampled subspecies of $L$. albicollis plus L. occidentalis (trans-), and (3) L. plumbeus (trans-) and the rest of Clade 1 (mostly cis-Andean, but with Buteogallus species occurring on both sides). The uncertain position of $L$. princeps may hide a possible fourth disjunction. Three major hypothesis have been suggested to explain the differentiation of ancestral populations into cis- and trans-Andean lineages: the Andean Uplift Hypothesis [43], advocating separation of populations on either side of the mountains as a consequence of Andean orogeny; the Across Andes Dispersal Hypothesis [43-45] proposing long distance dispersal across the Andes as the cause of diversification, and the Forest Refugia Hypothesis, with historical expansions and contractions of forest corridors that linked forested lowlands on either side of the Andes [45] (see Brumfield and Capparella [46], Ribas et al. [47]). Lack of fossil calibrations for raptors, as well as rejection of clock-like evolution for the ATP8 and ATP6 dataset using a likelihood ratio test (data not shown) precluded calculation of divergence times for the hawk species analyzed here, and thus without a temporal framework we are unable to reject any of the Andean biogeography hypotheses based solely on mtDNA phylogenetic inference.

Few geographic barriers besides the Andes seem to define ranges of Neotropical buteonine species. The Amazon River has been suggested to delineate the distributions of terra-firme forest species $[48,49]$, and may have played a role in the separation of L. melanops and L. kuhli north and south of the river, respectively (see [40]). However, there are recent and historical records of sympatry between $L$. melanops and L. kuhli, with observations of both species south of the Amazon River (Barlow et al. [50], Amaral et al. pers. obs.). Because of this fact it would appear that the Amazon River does not currently impose a strong barrier blocking L. melanops from occupying southern Amazon forests.

The putative contraction and expansion of lowland tropical forests associated with climate change has been promoted as one of the factors that explain avian areas of endemism (see [51] for limits and details on those areas), but most Neotropical buteonine species have geographic ranges that cross many of the proposed areas. Nonetheless, one might posit that the two Atlantic forest endemics, L. lacernulatus and L. polionotus represent species formed by the contraction and isolation of forest fragments during glacial episodes, but the mtDNA phylogenetic tree establishes that they are not sister species (Figure 1). The distant phylogenetic separation of these two Leucopternis species supports the proposal that the Atlantic Forest biota has complex origins [52].

Our mtDNA-based phylogenetic analysis of Neotropical buteonines (figure 2) also permits strong inference that forest and open-vegetation species are not reciprocally monophyletic. Furthermore, ecological shifts between forest and non-forest habitats occurred early and late in the Neotropical buteonine diversification. The phylogenetic tree presented in Figure 2 indicates that separation of the open-vegetation Buteo albicaudatus from Leucopternis forest species occurred early in the radiation compared to the more recent divergence of Buteogallus meridionalis from L. lacernulatus and Parabuteo unicinctus from Buteo leucorrhous. The geographic and altitudinal distributions of these more recently derived sister pairs overlap greatly, but the sister species occupy different habitats, either open-country or forest. This same pattern is reflected in the sister relationship between Harpyhaliaetus coronatus (savannah) and Harpyhaliaetus solitarius (forest, unavailable for this study) [28], although these species do not overlap much in their ranges.

Habitat shifts between sister species or groups of closely related species have been poorly explored in studies of avian historical biogeography in the Neotropics, mainly due to the predominance of forest lowland bird species in such studies (but see Garcia-Moreno and Cardoso da Silva [53] and Ribas et al. [54]). The pattern of habitat shifts between sister pairs can be consistent with both allopatric (Theory of Vanishing Refuges [55]) and parapatric models of speciation (Gradient Hypothesis [22]). Occurrence of parapatric speciation and divergence with gene flow has been a controversial issue (see Brown [56], Cracraft and Prum [57]), but explicit tests with vertebrates [58-61], including birds [62] have pointed to patterns consistent 
Table 2: Primers used in the study.

\begin{tabular}{|c|c|c|c|}
\hline Target region & Primer name & Sequence (5'to 3') & Reference \\
\hline \multirow[t]{8}{*}{$12 S$} & LPHEI 248 & AAAGCATGGCACTGAAGAYGCCAAG & E. Tavares, unpublished \\
\hline & I2SLI735 & GGATTAGATACCCCACTATGC & Miyaki et al. [75] \\
\hline & I2SHC & CCGCCAAGTCCTTAGAGTTT & Eberhard et al. [76] \\
\hline & $|2 \mathrm{SH} 2 \mathrm{I}|$ & GGCTTGTGAGGAGGGTGACGGGC & C. Ribas, unpublished \\
\hline & H2294VAL & CTTTCAGGTGTAAGCTGARTGC & J. Patane, modified from Sorenson et al. [77] \\
\hline & 16S2- & ATCCCTGGGGTAGCTTGGTCC & Haring et al. [78] \\
\hline & 16SH3309 & TGCGCTACCTTCGCACGGT & Miyaki et al. [75] \\
\hline & $\mathrm{H} 40 \mathrm{I7}$ & GCTAGGGAGAGGATTTGAACCTC & Sorenson et al. [77] \\
\hline \multirow[t]{5}{*}{ ATP8/6 } & CO2GQL & GGACAATGCTCAGAAATCTGCGG & Eberhard and Bermingham [79] \\
\hline & TLYS905। & CACCAGCACTAGCCTTTTAAG & Fleischer et al. [80] \\
\hline & A6PWL & CCTGAACCTGACCATGAAC & Eberhard and Bermingham [79] \\
\hline & $\mathrm{CO} \mathrm{HMH}$ & CATGGGCTGGGGTCRACTATGTG & Eberhard and Bermingham [79] \\
\hline & ARGIII45 & TTTGTTGAGCCGAAATCAACTGTCT & Present study \\
\hline \multirow[t]{3}{*}{ ND6 } & TPROFWD & ATCACCAACTCCCAAAGCTGG & Riesing et al. [7] \\
\hline & TGLUREV & AAGTTTACAACGGCGATTTTTC & Riesing et al. [7] \\
\hline & YCR2REV & GGTTACATGGTTTGGTAGGGG & Riesing et al. [7] \\
\hline
\end{tabular}

with between-habitat divergence in the presence of gene flow in tropical habitats. High mobility due to soaring and gliding flight, occurrence of several species in ecotones, and the pattern of sister relationships between forest and non-forest species suggest that buteonine species offer future opportunities to test alternative models of diversification in the Neotropics using phylogeographic data.

The determination of geographically structured areas of endemism in the Neotropics $[51,63]$ has promoted allopatry as the principal mode of speciation in the Neotropics, with the Andean orogeny, rivers, and changes in forest cover serving as the principal vicariant events separating populations. Accumulation of phylogenetic and phylogeographic data for Neotropical birds suggests that the process of diversification is more complex $[e . g$. $[42,64]]$, and that parapatric and sympatric models of speciation must be properly tested [19,23,58-62]. The family Accipitridae is extensively represented in most Neotropical habitats, and offers opportunities to explore the radiation of an ecologically diverse group with high dispersal capabilities. Further phylogenetic and phylogeographic studies of diurnal raptors, as well as other groups representing varying degrees of vagility and occurrence in habitats other than forests, will permit more explicit tests of the role of alternative modes of speciation acting on Neotropical birds, and refinement of general explanations for the origin and maintenance of Neotropical biodiversity.

\section{Conclusion}

Our mtDNA-based inference of Neotropical buteonine phylogeny establishes a polyphyletic relationship among the hawk genera Leucopternis, Buteogallus and Buteo. Thus the phylogeny indicates that the current taxonomy of the Accipitridae is not a good guide to the evolutionary relationships of species in the group, and identifies a need for further systematic analysis of the family at all taxonomic levels. We do not propose nomenclatural modifications, since only a complete buteonine analysis would permit such taxonomic changes. Nonetheless, our results coupled to earlier work predict some of the nomenclatural changes that will undoubtedly be forthcoming, and also establish that plumage has been overemphasized in defining the taxonomy of the Accipitridae. Finally, we conclude that shifts between forest and non-forest habitats, as well as movement across the Andes, have occurred more than once during the Neotropical buteonine diversification.

\section{Methods \\ Taxon sampling, DNA extraction, amplification and sequencing}

We sampled a total of 31 specimens, comprising all 10 recognized species of the genus Leucopternis (L. lacernulatus, L. polionotus, L. semiplumbeus, L. plumbeus, L. occidentalis, L. schistaceus, L. princeps, L. melanops, L. kuhli, L. albicollis), and including two sub-species of L. albicollis ( $L$. a. costaricensis and L. a. ghiesbreghti), as well as almost all Neotropical buteonine genera (representing 15 of the 21 species of the Neotropical "sub-buteonines" sensu Amadon [4]), plus four Buteo species. We chose Geranospiza caerulescens as an outgroup based on a recent higher-level analysis of Accipitridae [28]. When possible, we included two individuals per taxon. Nomenclature follows the South American Classification Committee of the American Ornithologists' Union [65]. Sequences of Buteo buteo 
were obtained from Genbank [NC 003128]. Tissue, feather and blood samples were obtained from specimens collected in the field, museum tissue collections, and captive birds (see Additional file 1: Table 1). Known localities of origin, feathers and photographs are available for most captive specimens.

DNA extraction, amplification and sequencing were performed at the Universidade de São Paulo (Brazil), the Smithsonian Tropical Institute (Panama) and the Royal Ontario Museum (Canada) based on earlier protocols [66]. DNA extraction followed Bruford et al. [67], or via the DNeasy kit (Qiagen); for feather samples, we added $30 \mathrm{ug}$ of dithiothreitol to the digestion buffer. We sequenced four mitochondrial genes: a portion of the $12 \mathrm{~S}$ ribosomal RNA gene (12S, longest sequence of $833 \mathrm{bp})$, the complete ATP synthase F0 subunit 8 (ATP8, $168 \mathrm{bp}$ ) and subunit 6 (ATP6, $684 \mathrm{bp}$ ) genes, as well as the complete NADH dehydrogenase subunit 6 (ND6, 519 bp) using several primer pair combinations via polymerase chain reaction (PCR) (table 2). In few cases, weak amplification products were re-amplified using internal primers. Both strands of the amplified products were sequenced.

\section{Alignment and phylogenetic analysis}

Multiple strands obtained for each specimen were assembled in CodonCode Aligner v. 1.3.4 (CodonCode Corporation) or Sequencher v. 4 (Gene Codes Corporation). Contigs were exported and alignment performed in Clustal X 1.83 [68] with default parameters. The $12 \mathrm{~S}$ alignment had 21 indels, which consisted mostly of autapomorphies and sites of ambiguous alignment; these were removed from all analyses. All single marker and combined datasets were tested for significant departures from average base frequencies with PAUP* 4b10 [69], using only variable sites. Uncorrected codon-based (ATP8, ATP6, ND6) and total (12S) transition and transversion distances were plotted against Kimura-2-parameters distances using the software Dambe v4.2 [70] to evaluate the effect of multiple substitutions in each dataset. We implemented a partition homogeneity test in PAUP*, using only variable sites with 1000 replicates with random additions, to evaluate the congruence of the phylogenetic signal between the different genes. Because the latter test did not detect significantly-different phylogenetic signal among the partitions $(P=0.29)$, all four genes were combined into a single combined dataset. Separated analyses of subsets of single gene region were also performed to evaluate the concordance among those datasets. The ATP8 and ATP6 genes overlap by $10 \mathrm{bp}$; however in all phylogenetic analyses of the combined dataset and the single gene region of ATP (subunit 8 plus subunit 6) this region was considered only once. We performed phylogenetic reconstructions using maximum likelihood
(ML) and maximum parsimony (MP) implemented in PAUP*, and Bayesian analysis (BA) with MrBayes v3.1.1 [71], to evaluate the concordance of topologies obtained under different optimization criteria. ML and MP heuristic searches were performed using 1000 and 10 random additions of sequences, respectively. Nonparametric bootstrapping was performed to assess branch support (100 replicates with single random additions for the ML analysis and 1,000 replicates with 10 random additions for the MP analysis). Modeltest v3.7 [72] was used to choose among evolutionary models of DNA substitution for ML and BA analyses using a hierarchical likelihood ratio test. Modeltest determined that the $\operatorname{Tr} \mathrm{N}+\mathrm{I}+\mathrm{G}$ model was the best fit for the total dataset with base frequencies of $\mathrm{A}=$ $0.3217, \mathrm{C}=0.3521, \mathrm{G}=0.1235, \mathrm{~T}=0.2027$, a gamma shape parameter of 1.0617 and proportion of invariable sites of 0.5631 . The BA analyses of the combined dataset was run with individual likelihood for each of the three gene regions (12S, ATP 6 and ATP 8, and ND6) as selected by Modeltest $(\mathrm{TrN}+\mathrm{I}+\mathrm{G}, \mathrm{HKY}+\mathrm{I}+\mathrm{G}, \mathrm{TrN}+\mathrm{G})$, which were the same models used for subset ML and BA analyses. MrBayes was run with four chains for 4,000,000 generations with trees sampled every 100 generations, replicated four times. All runs reached stationarity around 400 sampled generations, so we discarded the first 40000 generations as a "burnin"; a consensus topology was created with all the remaining sampled generations.

To determine whether our data support monophyly of Leucopternis, monophyly of forest species, monophyly of species presenting black and white plumage patterns, or reciprocal monophyly of trans- and cis-Andean species, we compared alternative constraint topologies to the ML tree using the nonparametric Shimodaira-Hasegawa test [73] implemented in PAUP*. Ancestral states of habitat and general plumage pattern (according to Thiollay [1], Fergusson-Lees and Christie [6] and Sibley and Monroe [39]) were mapped onto the ML tree inferred from the combined dataset using unordered parsimony in Mesquite v1.05 [74].

\section{Authors' contributions}

FSRA conceived the study, carried out most of the data collection and phylogenetic analysis, and drafted the manuscript. MJM carried out the data collection from the LSUMZ samples, and made substantial contributions to the manuscript. LFS obtained part of the samples, and made substantial contributions to the manuscript. EB made substantial contributions to the manuscript. AW helped to conceive the study, participated in its design and coordination and helped to draft the manuscript. All authors read and approved the final manuscript. 


\section{Additional material}

\section{Additional File 1}

Table 1. Samples used in the study. The classification follows Remsen et al. [65]. Abbreviations: LGEMA = Laboratório de Genética e Evolução Molecular de Aves, Universidade de São Paulo; LSUMZ = Louisiana State University, Museum of Natural Science; ANSP = Academy of Natural Sciences of Philadelphia; MPEG = Museu Paraense Emílio Goeldi; MZUSP = Museu de Zoologia da Universidade de São Paulo; IBUSP = Instituto de Biociências, Universidade de São Paulo.

Click here for file

[http://www.biomedcentral.com/content/supplementary/14712148-6-10-S1.rtf]

\section{Acknowledgements}

We thank the following individuals and institutions for kindly providing samples, without which this work could not have been performed: Donna Dittman, Robb Brumfield and Fred Sheldon (LSUMZ); Leo Joseph (ANSP); Alexandre Aleixo and Marcos Pérsio D. Santos (MPEG); Marcelo Soares (UFPA); Carlos E. A. Carvalho; Eduardo P. M. de Carvalho Filho; Giancarlo Zorzin, Gustavo D. M. de Carvalho and Marcus Canuto (SOS Falconiformes), Pedro Scherer Neto (Museu de História Natural Capão do Imbuía), Zoológico de Paulínia, Ricardo Pereira (Zoológico de São Paulo), Leo Fukui and Jorge Lisboa (ABPFAR); David Whitacre, Rick Watson and Martin Gilbert (Peregrine Fund); Tammo Hoeksema (ZOOMAT); Sérgio Aguilar (Veracruz Pronatura); Alexandre Miranda, José H. Fontenele, Greicelene R. Pedro (Orquidário de Santos); Renato Gaban-Lima and Guilherme Renzo (USP); Adriana Joppert (DEPAVE/SP); Robson Silva e Silva and Fábio Olmos. We are grateful to Erika $S$. Tavares for kindly sequencing the ANSP samples at the Royal Ontario Museum and helping with the analyses, and Allan Baker for allowing use of the ROM laboratory for sequencing. We also thank Sérgio Pereira and Martin Riesing for useful suggestions and support, Erwin T. Grau for invaluable help with the laboratory methods, Robb Brumfield for help with the analyses, and Camila Ribas, Cibele Biondo, Gustavo S. Cabanne, Rodrigo Pessoa and three anonymous referees for comments and several contributions to the manuscript. Financial support was provided by Fundação de Amparo a Pesquisa do Estado de São Paulo, CNPq and CAPES.

\section{References}

I. Thiollay JM: Family Accipitridae (Hawks and Eagles). In Handbook of the birds of the world. New World Vultures to Guineafowl Volume 2. Edited by: Hoyo J del, Elliott A, Sargatal J. Barcelona: Lynx Edicions; 1994:52-205.

2. Sick H: Ornitologia Brasileira Rio de Janeiro: Nova Fronteira; 1997.

3. Amadon D: Taxonomic notes on birds of prey. Amer Mus Novit 1964, 2 166: I-24.

4. Amadon D: A revision of the sub-buteonine hawks (Accipitridae, Aves). Amer Mus Novit 1982, 2741: I-20.

5. Olson SL: The fossil record of birds. In Avian biology Volume VIII. Edited by: Farner D, King J R, Parkes K. New York:Academic Press; 1985:79-239.

6. Ferguson-Lees J, Christie DA: Raptors of the world London: Christopher Helm; 2001.

7. Riesing MJ, Kruckenhauser L, Gamauf A, Haring E: Molecular phylogeny of the genus Buteo (Aves: Accipitridae) based on mitochondrial marker sequences. Mol Phylogenet Evol 2003, 27:328-342.

8. Helbig AJ, Kocum A, Seibold I, Braun MJ: A multi-gene phylogeny of aquiline eagles (Aves: Accipitriformes) reveals extensive paraphyly at the genus level. Mol Phyl Evol 2005, 35: |47-I64.
9. Amadon D, Bull J: Hawks and owls of the world. A distributional and taxonomic list. Proc West Found Vert Zool 1988, 3:295-357.

10. Friedman H: The birds of North and Middle America. Part XI. Cathartidae to Falconidae Volume 50. United States National Museum Bulletin 50. Washington D.C.: Smithsonian Institution; 1950.

II. Grossman ML, Hamlet J: Birds of prey of the world New York: Bonanza Books; 1964.

12. Brown LH, Amadon D: Eagles, hawks and falcons of the world Feltham: Country Life Books; 1968.

13. Haffer J: Speciation in Amazonian forest birds. Science 1969, 165: I3I-137.

14. Haffer J: Time's cycle and time's arrow in the history of Amazonia. Biogeographica 1993, 69:15-45.

15. Vanzolini PE, Williams EE: South American anoles: the geographical variation and and evolution of the Anolis chrysolepis species group (Sauria, Iguanidae). Arq Zool São Paulo 1970, 19: I-298.

16. Wallace AR: On the monkeys of the Amazon. Proc Zool Soc London I852, 20:107-II0.

17. Salo J, Kalliola R, Häkkinen I, Mäkinen Y, Niemelä P, Pubakka M, Coley PD: River dynamics and the diversity of Amazon lowland forest. Nature 1986, 322:254-258.

18. Räsänen ME, Linna AM, Santos JCR, Negri FR: Late Miocene tidal deposits in the Amazonian foreland basin. Science 1995, 269:386-390

19. Marroig G, Cerqueira R: Plio-Pleistocene South American history and the Amazon lagoon hypothesis: a piece in the puzzle of Amazonian diversification. J Comp Biol 1997, 2: I03-1 I9.

20. Nores M: An alternative hypothesis for the origin of Amazonian bird diversity. I Biogeography 1999, 26:475-485.

21. Platnick NI, Nelson G]: A method of analysis for historical biogeography. Syst Zool 1978, 27:1-16.

22. Endler JA: Pleistocene forest refuges: fact or fancy. In Biological Diversification in the Tropics Edited by: Prance GT. New York: Columbia University Press; 1982:64 I-657.

23. Moritz C, Patton JL, Schneider CJ, Smith TB: Diversification of rainforest faunas: an integrated molecular approach. Annu Rev Ecol Syst 2000, 31:533-563.

24. Dick CW, Abdul-Salim K, Bermingham E: Molecular systematic analysis reveals cryptic Tertiary diversification of a widespread tropical rain forest tree. Am Nat 2003, 162:69|-703.

25. Dick CW, Roubik DW, Gruber KF, Bermingham E: Long-distance gene flow and cross-Andean dispersal of lowland rainforest bees (Apidae: Euglossini) revealed by comparative mitochondrial DNA phylogeography. Mol Ecol 2004, I3:3775-3885.

26. Bildstein KL: Raptor migration in the Neotropics: patterns, processes and consequences. Ornitol Neotrop 2004:83-99.

27. Holdaway R: An exploratory phylogenetic analysis of the genera of the Accipitridae, with notes on the biogeography of the family. In Raptor conservation today: proceedings of the IV World Conference on Birds of Prey and Owls. 10-17 May 1992, Berlin Edited by: Meyburg BU, Chancellor RD. Berlin, London, Paris: Pica Press and World Working Group on Birds of Prey and Owls; 1994:60I-637.

28. Lerner HRL, Mindell DP: Phylogeny of eagles, Old World vultures, and other Accipitridae based on nuclear and mitochondrial DNA. Mol Phylogenet Evol 2005, 37:327-346.

29. Pereira SL, Baker AJ: Low number of mitochondrial pseudogenes in the chicken (Gallus gallus) nuclear genome: implications for molecular inference of population history and phylogenetics. BMC Evol Biol 2004, 4: 17.

30. Hellmayr CE, Conover B: Catalogue of Birds of the Americas. Field Mus Nat Hist Zool Ser 1949:13.

31. Pinto OMO: Catálogo das aves do Brasil e lista dos exemplares que as representam no Museu Paulista, I.a Parte. Aves não Passeriformes e Passeriformes não Oscines excluida a Fam. Tyrannidae e seguintes. Rev Mus Paulista 1938, 22: I-566

32. Plótnick R: Posicíon sistemática del género Heterospizias. Hornero 1956, 10:136-139.

33. Phelps WH, Phelps WH Jr: Lista de las aves de Venezuela con su distribucion. Tomo II. parte I. No Passeriformes. Bol Soc Venez Cienc Nat 1958, 19: I-317.

34. Meyer de Schauensee R: A guide to the birds of South America Wynnewood, Pennsylvania: Livingston Publishing; 1970.

35. Amadon D: Notes on Harpyhaliaetus. Auk 1949, 66:53-56. 
36. Amadon D, Eckelberry DR: Observations of Mexican Birds. Condor 1955, 57:65-80.

37. Ridgway R: Studies of the American Falconidae. Bull U S Geol Geog Surv Terr 1876, 2:91-182.

38. Stressemann E, Amadon D: Order Falconiformes. In Check-List of Birds of the World Volume I. 2nd edition. Edited by: Mayr E, Cottrell GW. Cambridge, Massachusetts: Museum of Comparative Zoology; | 1979:27|-425

39. Sibley CG, Monroe BL Jr: Distribution and taxonomy of birds of the world New Haven and London: Yale Univ Press; 1990.

40. Haffer J: Biogeography of Neotropical birds. In Biogeography and quaternary history in tropical America Edited by: Whitmore TC, Prance GT. Oxford:Clarendon Press; 1987

41. Omland KE, Lanyon SM: Reconstructing plumage evolution in orioles (Icterus): repeated convergence and reversal in patterns. Evolution 2000, 54:2119-2133.

42. Cheviron ZA, Hackett S], Capparella AP: Complex evolutionary history of a Neotropical lowland forest bird (Lepidothrix coronata) and its implications for historical hypotheses of the origin of Neotropical avian diversity. Mol Phylogenet Evol 2005, 36:338-357.

43. Chapman FM: The distribution of bird life in Colombia. Bull Am Mus Nat Hist 1917, 36: 1-729.

44. Chapman FM: The distribution of bird life in Colombia. Bull Am Mus Nat Hist 1926, 55: I-784.

45. Haffer J: Speciation in Colombian forest birds west of the Andes. American Museum Novitates 1967, 294: I-57.

46. Brumfiled RT, Capparella AP: Historical diversification of birds in northwestern South America: a molecular perspective on the role of vicariant events. Evolution 1996:1607-1624.

47. Ribas CC, Gaban-Lima R, Miyaki CY, Cracraft ]: Historical biogeography and diversification within the Neotropical parrot genus Pionopsitta (Aves:Psittacidae). J Biogeography 2005 32:1409-1427.

48. Capparella AP: Genetic variation in Neotropical birds: implications for the speciation process. Acta XIX Congr Int Ornithol I 988, 19:1658-1673.

49. Aleixo A: Historical diversification of a Terra-firme forest bird superspecies: a phylogeographic perspective on the role of different hypotheses of Amazonian diversification. Evolution 2004, 58:1303-1317.

50. Barlow J, Haugaasen T, Peres C: Sympatry of the Black-faced Hawk Leucopternis melanops and the White-browed Hawk Leucopternis kuhli in the Lower Rio Tapajós, Pará, Brazil. Cotinga 2002, 18:77-79.

5I. Cracraft J: Historical biogeography and patterns of differentiation within the South American avifauna: areas of endemism. Ornith Monogr 1985, 36:49-84.

52. Costa L: The historical bridge between Amazon and the Atlantic Forest of Brazil: a study of molecular phylogeography with small mammals. / Biogeography 2003, 30:71-86.

53. Garcia-Moreno J, Cardoso da Silva JM: An interplay between forest and non-forest South American avifaunas suggested by a phylogeny of Lepidocolaptes woodcreepers (Dendrocolaptidae). Stud Neotrop Fauna \& Environm 1997, 32:164-173.

54. Ribas CC, Miyaki CY: Molecular systematics in Aratinga parakeets: species limits and historical biogeography in the 'solstitialis' group, and the systematic position of Nandayus nenday. Mol Phylogenet Evol 2004, 30:663-675.

55. Vanzolini PE, Williams EE: The vanishing refuge: a mechanism for ecogeographic speciation. Pap Avulsos Zoo I98I, 34:25I-255.

56. Brown KS Jr: Conclusions, synthesis, and alternative hypothesis. In Biogeography and quaternary history in tropical America Edited by: Whitmore TC, Prance GT. New York: Clarendon Press: 1987:175-196.

57. Cracraft J, Prum RO: Patterns and processes of diversification: speciation and historical congruence in some Neotropica birds. Evolution 1988, 42:603-620.

58. Schneider CJ, Smith TB, Larison B, Moritz C: $\mathbf{A}$ test of alternative models of diversification in tropical rainforests: ecological gradients vs rainforest refugia. Proc Nat Acad Sci USA 1999, 24:13869-13873.

59. Smith TB, Wayne RK, Girman DJ, Bruford MW: A role for ecotones in generating rainforest biodiversity. Science 1997 , 276: $1855-1857$
60. Smith TB, Schneider CJ, Holder K: Refugial isolation versus ecological gradients. Genetica 200 I, I I 2-I I 3:383-398.

61. Ogden R, Thorpe RS: Molecular evidence for ecological speciation in tropical habitats. Proc Natl Acad Sci USA 2002, 99:|36|2-136|5

62. Smith TB, Calsbeek R, Wayne RK, Holder KH, Pires D, Bardeleben $C$ : Testing alternative mechanisms of evolutionary divergence in an African rain forest passerine bird. J Evol Biol 2005, 18:257-268.

63. Bates JM, Hackett SJ, Cracraft J: Area-relationships in the Neotropical lowlands: a hypothesis based on raw distributions of Passerine birds. J Biogeography 1998, 25:783-793.

64. Marks BD, Hackett SJ, Capparella AP: Historical relationships among Neotropical lowland forest areas of endemism as determined by mitochondrial DNA sequence variation within the Wedge-billed Woodcreeper (Aves: Dendrocolaptidae: Glyphorynchus spirurus). Mol Phylogenet Evol 2002, 24:I53-I67.

65. Remsen JV Jr, Jaramillo A, Nores M, Pacheco JF, Robbins MB, Schulenberg TS, Stiles FG, da Silva JMC, Stotz DF, Zimmer KJ: A classification of the bird species of South America. American Ornithologists' Union. [http://www.museum.Isu.edu/ Remsen/ SACCBaseline.html]. [Version 30 november 2005]

66. Tavares ES, Yamashita C, Miyaki CY: Phylogenetic relationships among some Neotropical parrot genera (Psittacidae) based on mitochondrial sequences. Auk 2004, I 2 I:230-242.

67. Bruford MW, Hanotte O, Brookfield JFY, Burke T: Multi and singlelocus DNA fingerprinting. In Molecular Genetic Analysis of Populations - a Practical Approach Edited by: Hoelzel AR. New York: IRL Press; 1992:225-269.

68. Thompson JD, Gibson TJ, Plewniak F, Jeanmougin F, Higgins DG: The ClustalX windows interface: flexible strategies for multiple sequence alignment aided by quality analysis tools. Nucleic Acids Res 1997, 25:4876-4882.

69. Swofford DL: PAUP* Phylogenetic analysis using parsimony (*and other methods) Sunderland, Massachusetts: Sinauer Associates; 2002.

70. Xia X, Xie Z: DAMBE: Data analysis in molecular biology and evolution. Journal of Heredity 2001, 92:37I-373.

7I. Ronquist F, Huelsenbeck JP: MRBAYES 3: Bayesian phylogenetic inference under mixed models. Bioinformatics 2003, 19:1572-1574.

72. Posada D, Crandall KA: MODELTEST: testing the model of nucleotide substitution. Bioinformatics $1998,14: 817-8 \mid 8$.

73. Shimodaira $\mathrm{H}$, Hasegawa M: Multiple comparisons of log-likelihoods with applications to phylogenetic inference. Mol Biol Evol 1999, 16: III4-III6.

74. Maddison WP, Maddison DR: Mesquite: a modular system for evolutionary analysis. Version I.05. 1999 [http://mesquite project.org]

75. Miyaki CY, Matioli S, Burke T, Wajntal A: Parrot evolution and paleogeographic events: mitochondrial DNA evidence. Mol Biol Evol 1998, I5:544-55I.

76. Eberhard JR, Wright TF, Bermingham E: Duplication and concerted evolution of the mitochondrial control region in the parrot genus Amazona. Mol Biol Evol 200 I, 18: I330-1342.

77. Sorenson MD, Ast JC, Dimcheff DE, Yuri T, Mindell DP: Primers for a PCR-based approach to mitochondrial genome sequencing in birds and other vertebrates. Mol Phylogenet Evol 1999, I 2:105-1|4.

78. Haring E, Kruckenhauser L, Gamauf A, Riesing MJ, Pinsker W: The complete sequence of the mitochondrial genome of Buteo buteo (Aves, Accipitridae) indicates an early split in the phylogeny of raptors. Mol Biol Evol 2001, 18: I892-1904.

79. Eberhard JR, Bermingham E: Phylogeny and biogeography of the Amazona ocrocephala (Aves:Psittacidae) complex. Auk 2004, I 21:318-332

80. Fleischer RC, Olson SL, James HF, Cooper AC: Identification of the extinct Hawaiian eagle (Haliaeetus) by mtDNA sequence analysis. Auk 2000, I 17:1051-1056. 